Development of a Composite

Non-Electrostatic Surface Complexation Model Describing Plutonium Sorption to Aluminosilicates

Brian A. Powell, Annie Kersting, Mavrik Zavarin, Plhong Zhao

January 06, 2011 
This document was prepared as an account of work sponsored by an agency of the United States government. Neither the United States government nor Lawrence Livermore National Security, LLC, nor any of their employees makes any warranty, expressed or implied, or assumes any legal liability or responsibility for the accuracy, completeness, or usefulness of any information, apparatus, product, or process disclosed, or represents that its use would not infringe privately owned rights. Reference herein to any specific commercial product, process, or service by trade name, trademark, manufacturer, or otherwise does not necessarily constitute or imply its endorsement, recommendation, or favoring by the United States government or Lawrence Livermore National Security, LLC. The views and opinions of authors expressed herein do not necessarily state or reflect those of the United States government or Lawrence Livermore National Security, LLC, and shall not be used for advertising or product endorsement purposes.

This work performed under the auspices of the U.S. Department of Energy by Lawrence Livermore National Laboratory under Contract DE-AC52-07NA27344. 


\title{
Development of a Composite Non-Electrostatic Surface Complexation Model Describing Plutonium Sorption to Aluminosilicates
}

\author{
by \\ ${ }^{1}$ Brian A. Powell, ${ }^{2}$ Annie Kersting, ${ }^{2,3}$ Mavrik Zavarin, ${ }^{2,3}$ Pihong Zhao
}

${ }^{1}$ Environmental Engineering and Earth Sciences, Clemson University

${ }^{2}$ The Glenn T. Seaborg Institute, Physical and Life Sciences Directorate, Lawrence Livermore National Laboratory

${ }^{3}$ Environmental Radiochemistry Group, Physical and Life Sciences Directorate, Lawrence Livermore National Laboratory

January, 2011 


\section{TABLE OF CONTENTS}

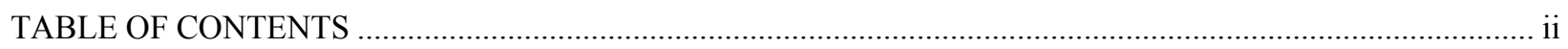

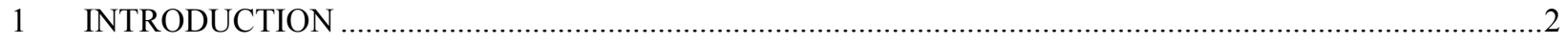

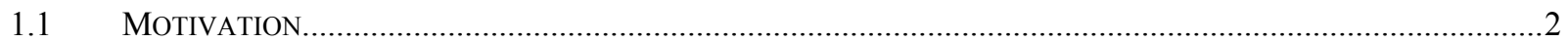

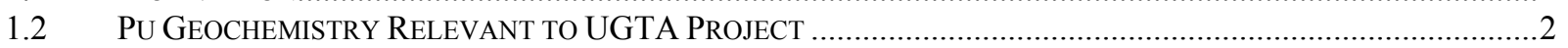

1.3 Composite SuRface COMPLEXATION MOdELING APPROACH .......................................................................

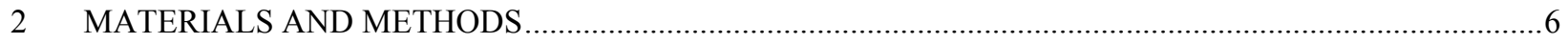

2.1 SOLID PHASE PREPARATION AND CHARACTERIZATION ........................................................................

2.2 PlUTONIUM WORKING SOLUTION PREPARATION AND CHARACTERIZATION ............................................9

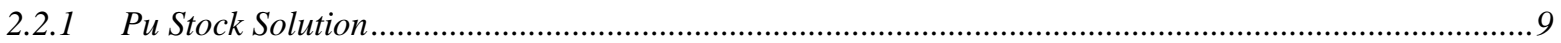

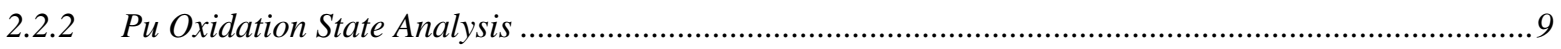

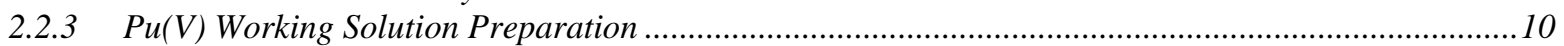

2.2.4 Pu(IV) Working Solution Preparation ............................................................................................10

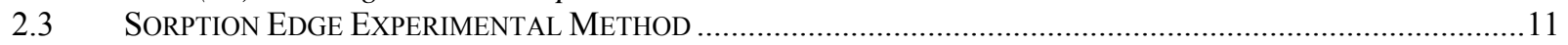

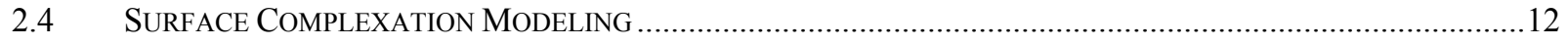

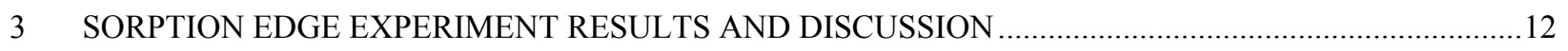

3.1 Pu(IV) AND Pu(V) CONTROL (SOLID-FREE) SOLUTIONS .......................................................................12

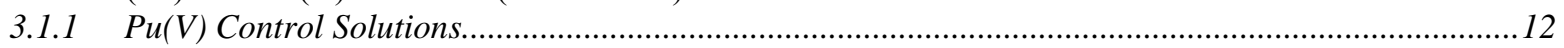

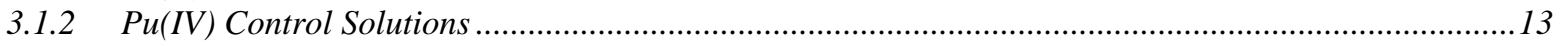

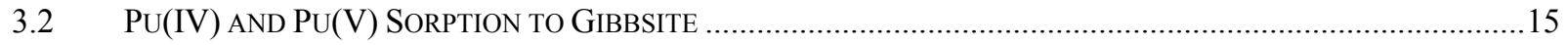

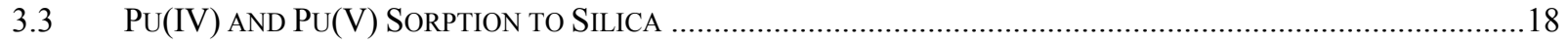

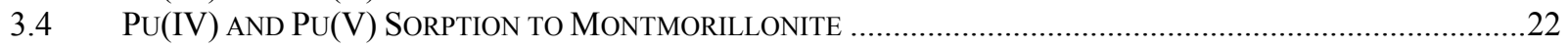

4 SURFACE COMPLEXATION MODELING USING EXISTING UGTA CONCEPTUAL MODEL .............25

4.1 Description of CuRrent UGTA Non-Electrostatic Surface Complexation Model ....................25

4.2 PREDICTION OF PU SORPTION USING CURRENT UGTA DATABASE ........................................................27

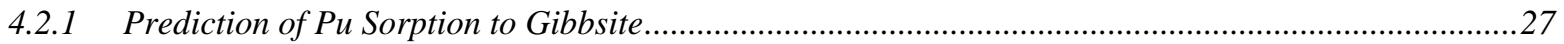

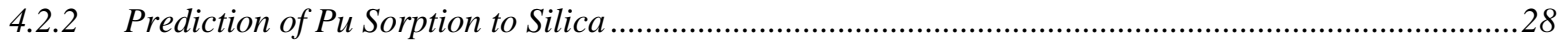

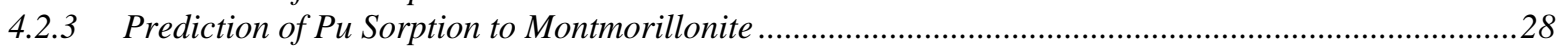

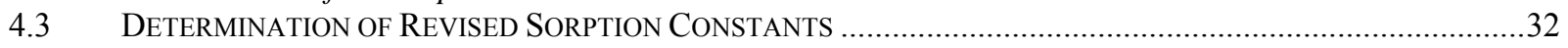

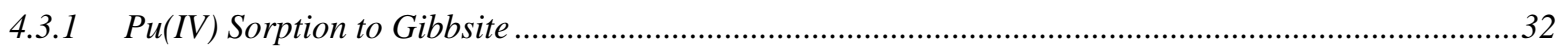

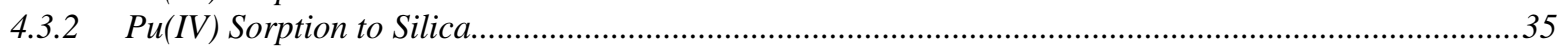

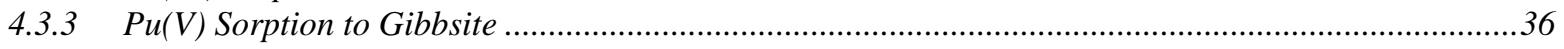

4.3.4 $\mathrm{Pu}(\mathrm{V})$ Sorption to Silica ...................................................................................................................

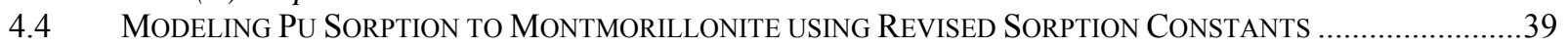

4.4.1 $\mathrm{Pu}(\mathrm{V})$ Sorption to Montmorillonite ........................................................................................................

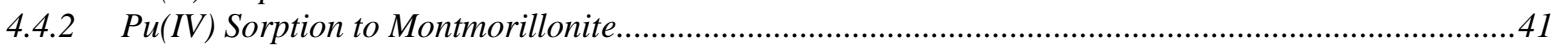

5 SURFACE COMPLEXATION MODELING WITH INCORPORATION OF Pu(IV)/Pu(V) REDOX

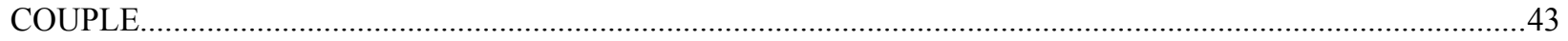

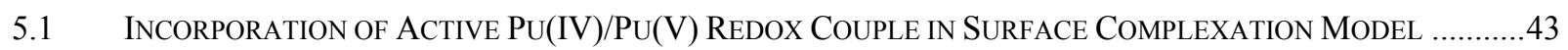

5.2 Refinement OF Model with ACTIVE PU(IV)/Pu(V) Redox COUPLE ...................................................47

5.3 Modeling Pu Sorption to Montmorillonite With Active Pu(IV)/Pu(V) Redox Couple .................51

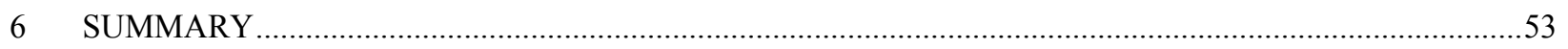

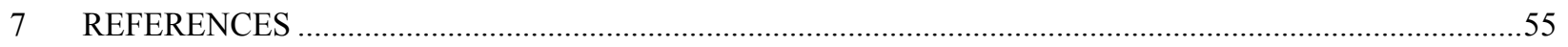

APPENDIX A - Solid Phase Charachterization Data Provided by Manufacturer .......................................................59 
APPENDIX B - Volumes of $\mathrm{NaCl}, \mathrm{HCl}, \mathrm{NaOH}$, Mineral Suspensions, Pu Working Solutions, and Carbonate Solutions Used for Sample Preparation at $\mathrm{I}=0.01 \mathrm{M}$.

APPENDIX C - Sorption Data and Species Concentrations Used for Development of Surface Complexation Model

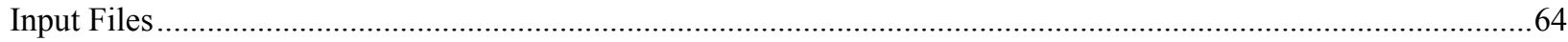




\section{ABSTRACT}

Due to their ubiquity in nature and chemical reactivity, aluminosilicate minerals play an important role in retarding actinide subsurface migration. However, very few studies have examined $\mathrm{Pu}$ interaction with clay minerals in sufficient detail to produce a credible mechanistic model of its behavior. In this work, $\mathrm{Pu}(\mathrm{IV})$ and $\mathrm{Pu}(\mathrm{V})$ interactions with silica, gibbsite (Aloxide), and Na-montmorillonite (smectite clay) were examined as a function of time and $\mathrm{pH}$. Sorption of $\mathrm{Pu}(\mathrm{IV})$ and $\mathrm{Pu}(\mathrm{V})$ to gibbsite and silica increased with $\mathrm{pH}$ (4 to 10). The $\mathrm{Pu}(\mathrm{V})$ sorption edge shifted to lower $\mathrm{pH}$ values over time and approached that of $\mathrm{Pu}(\mathrm{IV})$. This behavior is apparently due to surface mediated reduction of $\mathrm{Pu}(\mathrm{V})$ to $\mathrm{Pu}(\mathrm{IV})$. Surface complexation constants describing $\mathrm{Pu}(\mathrm{IV}) / \mathrm{Pu}(\mathrm{V})$ sorption to aluminol and silanol groups were developed from the silica and gibbsite sorption experiments and applied to the montmorillonite dataset. The model provided an acceptable fit to the montmorillonite sorption data for $\mathrm{Pu}(\mathrm{V})$. In order to accurately predict $\mathrm{Pu}(\mathrm{IV})$ sorption to montmorillonite, the model required inclusion of ion exchange. 


\section{INTRODUCTION}

\subsection{Motivation}

The objective of this work is to measure the sorption of $\mathrm{Pu}(\mathrm{IV})$ and $\mathrm{Pu}(\mathrm{V})$ to silica, gibbsite, and smectite (montmorillonite). Aluminosilicate minerals are ubiquitous at the Nevada National Security Site and improving our understanding of Pu sorption to aluminosilicates (smectite clays in particular) is essential to the accurate prediction of Pu transport rates. These data will improve the mechanistic approach for modeling the hydrologic source term (HST) and provide sorption $\mathrm{Kd}$ parameters for use in CAU models. In both alluvium and tuff, aluminosilicates have been found to play a dominant role in the radionuclide retardation because their abundance is typically more than an order of magnitude greater than other potential sorbing minerals such as iron and manganese oxides (e.g. Vaniman et al., 1996).

The sorption database used in recent HST models (Carle et al., 2006) and upscaled for use in CAU models (Stoller-Navarro, 2008) includes surface complexation constants for U, Am, Eu, $\mathrm{Np}$ and $\mathrm{Pu}$ (Zavarin and Bruton, 2004). Generally, between 15 to 30 datasets were used to develop the constants for each radionuclide. However, the constants that describe Pu sorption to aluminosilicates were developed using only 10 datasets, most of which did not specify the oxidation state of $\mathrm{Pu}$ in the experiment. Without knowledge or control of the $\mathrm{Pu}$ oxidation state, a high degree of uncertainty is introduced into the model. The existing Pu surface complexation model (e.g. Zavarin and Bruton, 2004) drastically underestimates Pu sorption and, thus, will overestimate Pu migration rates (Turner, 1995). Recent HST simulations at Cambric (Carle et al., 2006) suggest that the existing surface complexation model may underpredict $\mathrm{Pu} \mathrm{K}_{\mathrm{d}} \mathrm{s}$ by as much as 3 orders of magnitude. ${ }^{1}$ In order to improve HST and CAU-scale transport models (and, as a result, reduce the conservative nature $\mathrm{Pu}$ migration estimates), sorption experiments were performed over a range of solution conditions that brackets the groundwater chemistry of the Nevada National Security Site. The aluminosilicates examined were gibbsite, silica, and montmorillonite.

\subsection{Pu Geochemistry Relevant to UGTA Project}

Under environmental conditions, plutonium can exist in four possible oxidation states, possibly simultaneously. The coexistence of plutonium at several oxidation states is due to the proximity of electrochemical potentials among each redox couple (Table 1.1). In neutral $\mathrm{pH}$ oxic solutions, the predominant oxidation states are $\mathrm{Pu}(\mathrm{IV}), \mathrm{Pu}(\mathrm{V})$, and $\mathrm{Pu}(\mathrm{VI})$. Due to the negative formal electrochemical potential of the $\mathrm{Pu}(\mathrm{IV}) / \mathrm{Pu}$ (III) couple, $\mathrm{Pu}$ (III) can be oxidized by water at neutral $\mathrm{pH}$ values. Neither highly reducing nor highly oxidizing conditions were maintained in the present work. Therefore, the predominant oxidation states are expected to be $\mathrm{Pu}(\mathrm{IV})$ and $\mathrm{Pu}(\mathrm{V})$. These oxidation states represent the $\mathrm{Pu}$ species with the highest $(\mathrm{Pu}(\mathrm{V}))$ and lowest $(\mathrm{Pu}(\mathrm{IV}))$ subsurface mobilities and, therefore, "bound" the range of potential Pu mobility.

\footnotetext{
${ }^{1}$ The difference between measured and predicted cavity $\mathrm{k}_{\mathrm{d}} \mathrm{s}$ at Cambric are likely the result of a combination of effects which includes uncertainty in radionuclide partitioning, sorption/desorption reversibility, as well as sorption affinity.
} 
Table 1.1 Formal electrochemical potentials for Pu redox couples (versus SHE). Table modified from Clark et al. (2006).

\begin{tabular}{|c|c|c|c|}
\hline Couple & Acidic $^{\mathrm{a}}$ & Neutral $^{\mathrm{b}}$ & Basic $^{\mathrm{c}}$ \\
\hline $\mathrm{Pu}(\mathrm{IV}) / \mathrm{Pu}(\mathrm{III})$ & 0.982 & -0.39 & -0.96 \\
\hline $\mathrm{Pu}(\mathrm{V}) / \mathrm{Pu}(\mathrm{IV})$ & 1.170 & 0.70 & $-0.67,0.52^{\mathrm{d}}$ \\
\hline $\mathrm{Pu}(\mathrm{VI}) / \mathrm{Pu}(\mathrm{V})$ & 0.913 & 0.60 & 0.12 \\
\hline $\mathrm{Pu}(\mathrm{VI}) / \mathrm{Pu}(\mathrm{IV})$ & 1.043 & 0.65 & 0.34 \\
\hline \multicolumn{4}{|c|}{ 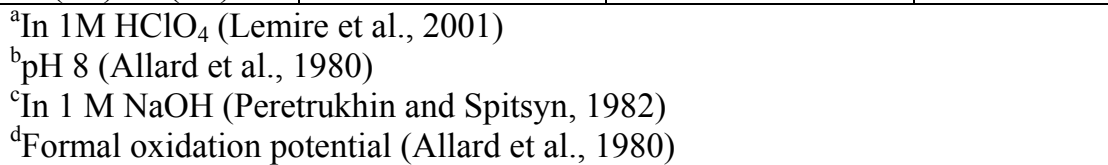 } \\
\hline
\end{tabular}

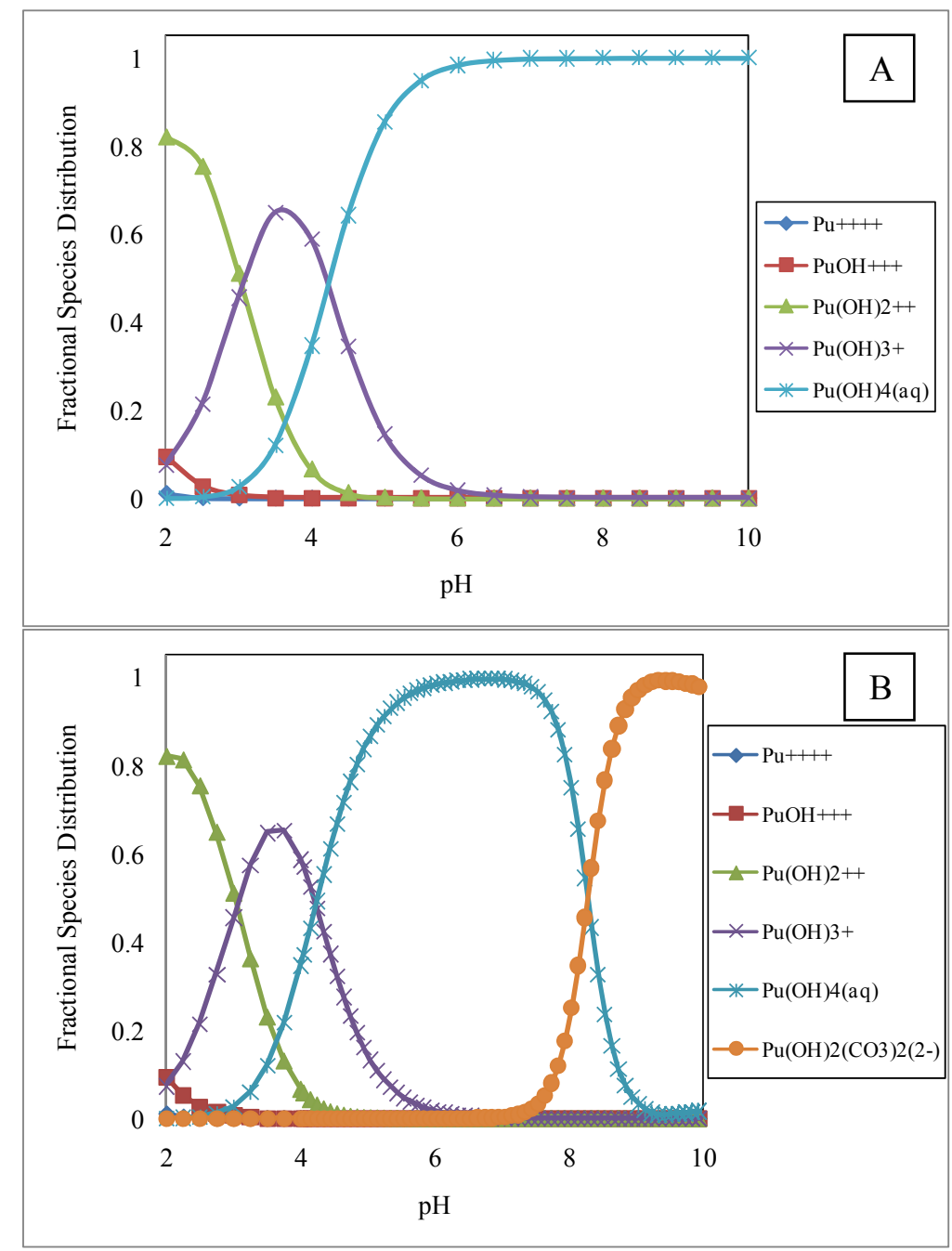

Figure 1.1: Speciation of $\mathrm{Pu}(\mathrm{IV})$ in(A) $\mathrm{CO}_{2}(\mathrm{~g})$-free and (B) atmospheric $\mathrm{CO}_{2}(\mathrm{~g})$-equilibrated systems, respectively. Calculations performed using thermodynamic constants from the existing UGTA database. 
Tetravalent $\mathrm{Pu}$ undergoes extensive hydrolysis to form $\mathrm{Pu}(\mathrm{OH})_{\mathrm{x}}{ }^{4-\mathrm{x}}$ species (Figure 1.1a). ${ }^{2}$ Even in acidic solutions, $\mathrm{Pu}(\mathrm{IV})$ is not present as a free ion. Rather hydrolysis begins near $\mathrm{pH} 1$ and progresses in a stepwise manner until the $\mathrm{Pu}(\mathrm{OH})_{4}(\mathrm{aq})$ species is dominant at $\mathrm{pH}>4$. In addition, hydrolysis products can polymerize and form colloidal or macroscopic precipitates. The aqueous phase concentration of $\mathrm{Pu}(\mathrm{IV})$ is limited by the formation of these insoluble precipitates. Rai et al. (2001) reported solubility product values for amorphous $\mathrm{Pu}(\mathrm{OH})_{4}(\mathrm{~s})$ of $10^{-56}$. Using only this constant, the maximum aqueous $\mathrm{Pu}$ concentration at neutral $\mathrm{pH}$ values would be in the $10^{-13}$ to $10^{-15} \mathrm{M}$ range. However, during Pu solubility studies in oxic solutions, $10^{-6} \mathrm{M}$ aqueous $\mathrm{Pu}$ concentrations are routinely measured. The higher $\mathrm{Pu}$ concentrations are due to oxidation of $\mathrm{Pu}(\mathrm{IV})$ to more soluble $\mathrm{Pu}$ (V/VI) species and formation of colloidal Pu(IV) (Neck et al., 2007; Rai et al., 2001). Neck et al. (2007) recently determined an equilibrium constant of $\log \mathrm{K}=-8.3$ $+/-1.0$ for $\mathrm{Pu}(\mathrm{IV})_{\text {colloid. }}$ Soderholm et al. (2008) determined that aggregated $\mathrm{Pu}$ colloids are comprised of $\sim 2 \mathrm{~nm}$ crystalline Pu colloids. Oxidation state measurements by Rai et al. (1999) and Neck et al. (2007) have verified aqueous $\mathrm{Pu}(\mathrm{V})$ and $\mathrm{Pu}(\mathrm{VI})$ in $\mathrm{Pu}$ solubility experiments. From these data, a solubility model based on equilibrium with $\mathrm{PuO}_{2+x}$ was reported. Trace levels of dissolved oxygen were observed to affect the data indicating oxidation of $\mathrm{Pu}(\mathrm{IV})$ by dissolved oxygen in these systems (Neck et al., 2007).

The highly charged nucleus of $\mathrm{Pu}(\mathrm{V})$ is stabilized by axial oxygen bonds such that the predominant $\mathrm{Pu}(\mathrm{V})$ solution species is $\mathrm{PuO}_{2}{ }^{+}$. The axial oxygen bonds lower the effective charge of $\mathrm{Pu}$ to approximately +2.2 . This lowered effective charge limits the affinity of $\mathrm{Pu}(\mathrm{V})$ for solid phases. Therefore, $\mathrm{Pu}(\mathrm{V})$ readily partitions to the aqueous phase and remains relatively mobile in the subsurface. At high $\mathrm{Pu}$ concentrations, $\mathrm{Pu}(\mathrm{V})$ has a tendency to disproportionate. As a result, there are very few studies of $\mathrm{Pu}(\mathrm{V}) \mathrm{O}_{2}{ }^{+}$hydrolysis. The thermodynamic constants used in the current UGTA database were taken primarily from DATACOM.V8.r6 of the GEMBOCHS thermodynamic database (Turner et al., 1998). These constants (discussed and listed in Chapter 4) were used to calculate the aqueous $\mathrm{Pu}(\mathrm{V})$ speciation shown in Figure 1.2. Due to its low complexation affinity, $\mathrm{PuO}_{2}{ }^{+}$remains a free oxycation up to $\mathrm{pH} 8$.

The hydrolysis behavior of $\mathrm{Pu}(\mathrm{IV})$ and $\mathrm{Pu}(\mathrm{V})$ is related to sorption behavior. At low $\mathrm{pH}, \mathrm{Pu}(\mathrm{IV})$ undergoes strong hydrolysis (Figure 1.1). Under these same conditions, $\mathrm{Pu}(\mathrm{IV})$ tends to sorb strongly to mineral surfaces, presumably through formation of inner sphere surface complexes with surface hydroxyl groups. $\mathrm{Pu}(\mathrm{V})$ does not undergo hydrolysis until $\mathrm{pH} \sim 8$ (Figure 1.2) and significant sorption is not typically observed until $\mathrm{pH}>7$. At low $\mathrm{pH}, \mathrm{Pu}(\mathrm{V})$ sorption is weak due to electrostatic repulsion of the positive mineral surface and the dioxycation $\mathrm{PuO}_{2}{ }^{+}$. The correlation between hydrolysis and sorption behavior was the basis for the proposal by Bradbury and Baeyens (2005) that linear free energy relationships between sorption constants and hydrolysis constants can be used to predict sorption behavior.

In systems with carbonate present, both $\mathrm{Pu}(\mathrm{IV})$ and $\mathrm{Pu}(\mathrm{V})$ are expected to form carbonate species above $\mathrm{pH} 8$ (Figures $1.1 \mathrm{~b}$ and 1.2b). The effects of these carbonate species on $\mathrm{Pu}$ sorption has not been rigorously examined. However, it is expected that formation of soluble, anionic carbonate species will prevent Pu sorption. The importance of soluble $\mathrm{Pu}(\mathrm{IV})$ carbonates

\footnotetext{
${ }^{2}$ The hydrolysis constants used to calculate the speciation diagrams in Figure 1.1 are those currently employed in the UGTA thermochemical database. The constants and this database will be discussed in greater detail below.
} 
was demonstrated in a study by Rai et al. (1999) where formation fo $\mathrm{Pu}(\mathrm{IV})$ hydroxycarbonates was found to increase the solubility of $\mathrm{Pu}(\mathrm{IV})$ in $\mathrm{PuO}_{2}(\mathrm{am})$ saturated systems.

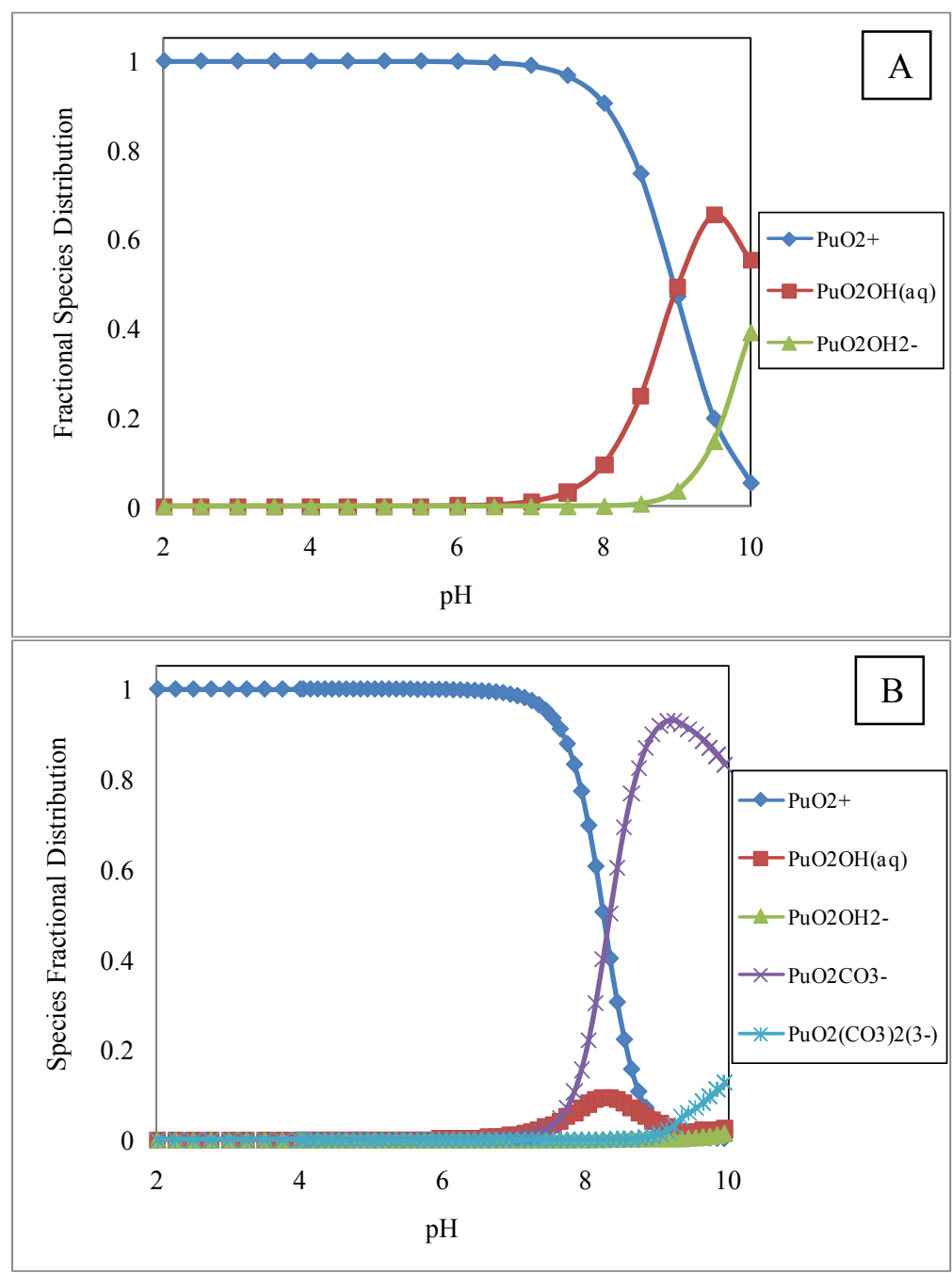

Figure 1.2: Speciation of $\mathrm{Pu}(\mathrm{V})$ in $(\mathrm{A}) \mathrm{CO}_{2}(\mathrm{~g})$-free and (B) atmospheric $\mathrm{CO}_{2}(\mathrm{~g})$-equilibrated systems, respectively. Calculations performed using thermodynamic constants from the existing UGTA database.

\subsection{Composite Surface Complexation Modeling Approach}

In the present work, a composite surface complexation model (SCM) was developed by first generating surface complexation constants describing $\mathrm{Pu}(\mathrm{IV})$ and $\mathrm{Pu}(\mathrm{V})$ sorption to gibbsite and silica. Those constants were then used to predict $\mathrm{Pu}$ sorption to montmorillonite. The major assumption in this model is that the clay edge sites on montmorillonite that contain tetrahedral silica sites and octahedral alumina sites (Figure 1.3) will behave as aluminol (AlOH) and silanol $(\mathrm{SiOH})$ sites in gibbsite and silica, respectively. A similar modeling approach was used by Turner et al. (1998) and McKinley et al. (1995) to model Np(V) and U(VI) sorption to montmorillonite, respectively. In the case of $\mathrm{Pu}$, this modeling approach is complicated by the 
redox cycling between $\mathrm{Pu}(\mathrm{IV})$ and $\mathrm{Pu}(\mathrm{V})$. As discussed above, the various $\mathrm{Pu}$ oxidation states exhibit drastically different sorption behavior. Therefore, a model capable of predicting not only partitioning of $\mathrm{Pu}$ but the oxidation state speciation would provide a more robust, mechanistic description of Pu geochemical behavior. To date, such a model has not been developed and incorporated into reactive transport modeling efforts. To allow for integration with the existing UGTA database and to compare the effects of the $\mathrm{Pu}(\mathrm{IV}) / \mathrm{Pu}(\mathrm{V})$ couple on model output, two modeling exercises are presented in this work. In the first, a non-electrostatic surface complexation model was developed without coupling $\mathrm{Pu}(\mathrm{IV})$ and $\mathrm{Pu}(\mathrm{V})$ (Chapter 4). In the second exercise, the $\mathrm{Pu}(\mathrm{IV}) / \mathrm{Pu}(\mathrm{V})$ redox couple was based upon the following reaction (Chapter $5)$ :

$$
\mathrm{Pu}^{4+}+0.25 \mathrm{O}_{2}(\mathrm{~g})+1.5 \mathrm{H}_{2} \mathrm{O} \leftrightarrow \mathrm{PuO}_{2}^{+}+3 \mathrm{H}^{+} \quad \log \mathrm{K}=3.439
$$

This second modeling exercise is meant to demonstrate incorporation of the $\mathrm{Pu}(\mathrm{IV}) / \mathrm{Pu}(\mathrm{V})$ redox couple into modeling efforts to provide a more technically accurate model.

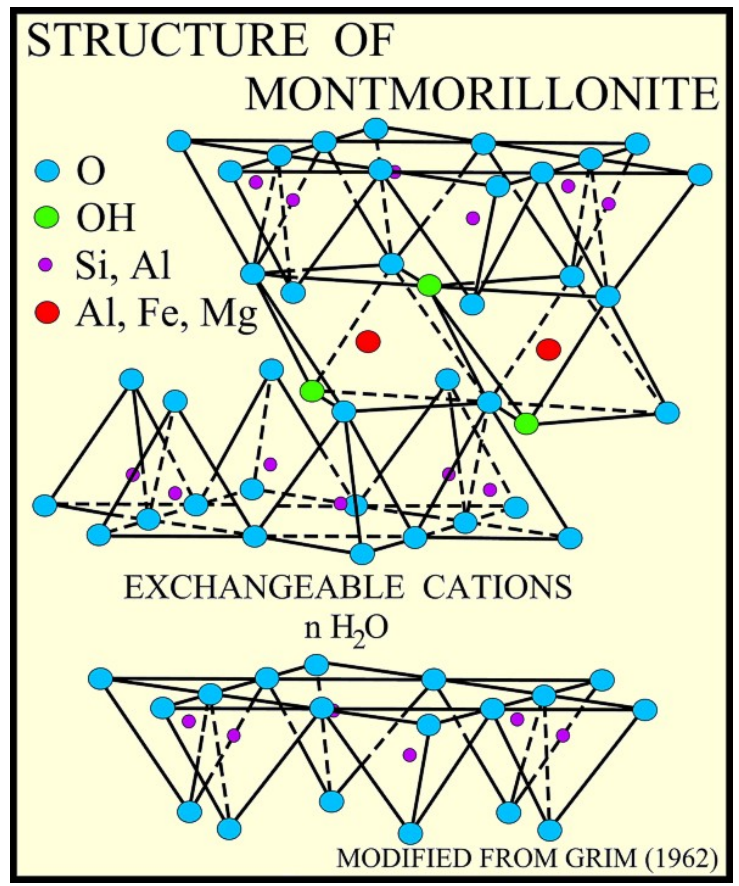

Figure 1.3 Structure of montmorillonite. Image downloaded from http://pubs.usgs.gov/of/2001/of01041/htmldocs/images/monstru.jpg

\section{MATERIALS AND METHODS}

\subsection{Solid Phase Preparation and Characterization}

The current work utilized silica, gibbsite and montmorillonite. The silica was obtained from Unimin Corporation (Spruce Pine, NC) as Iota 8 high purity quartz. Typical contaminant concentrations are shown in Appendix A. The gibbsite $\left(\alpha-\mathrm{Al}(\mathrm{OH})_{3}\right)$ was obtained from Ward's Natural Science (Rochester, NY). The montmorillonite is sample SWY-1 from the Clay Minerals 
Society. All available physical and chemical information provided by the manufacturers is reported in Appendix A. The $\mathrm{N}_{2}(\mathrm{~g})$-BET surface area of all solid phases was measured using a Micrometrics Gemini surface area analyzer. All solid phases were degassed using a nitrogen stream at $110^{\circ} \mathrm{C}$ for 24 hours prior to measuring surface area.

Unimun Corporation reports a silica particle size range of 75-300 $\mu \mathrm{m}$. In order to increase the surface area, 2 gram aliquots were ground in a ball-mill for 20 minutes each.

The gibbsite and milled silica were cleaned by adding $10 \mathrm{~g}$ of each phase to a $180 \mathrm{~mL}$ centrifuge bottle with approximately $180 \mathrm{~mL} 0.01 \mathrm{M} \mathrm{NaOH}$. The suspension was mixed for one hour then centrifuged 60 minutes at $4500 \mathrm{rpm}$ in a swing-bucket rotor (centrifuge: Allegra-22R, rotor: $\mathrm{S} 4180$ ). This left particles less than $150 \mathrm{~nm}$ in suspension. The $\mathrm{NaOH}$ supernatant was decanted and the solution was replaced with $0.01 \mathrm{M} \mathrm{HNO}_{3}$, mixed for 1 hour, then centrifuged as described above. The $\mathrm{HNO}_{3}$ phase was decanted and replaced with ultrapure $\mathrm{MQ} \mathrm{H}_{2} \mathrm{O}$. This suspension was mixed by hand for approximately 3 minutes then centrifuged, the aqueous phase decanted, and the procedure repeated 5 times. The final wet solids were transferred to a glass petri dish and dried in an oven at $105{ }^{\circ} \mathrm{C}$. After drying, the solids were lightly ground with a mortar and pestle to break up aggregates then stored in glass vials. The surface area of the silica and gibbsite were measured as $1.2 \mathrm{~m}^{2} \mathrm{~g}^{-1}$ and $1.9 \mathrm{~m}^{2} \mathrm{~g}^{-1}$, respectively.

The SWy-1 montmorillonite was pre-treated by suspending $15 \mathrm{~g}$ montmorillonite in $150 \mathrm{~mL}$ $0.001 \mathrm{M} \mathrm{HCl}$. The suspension was mixed for 30 minutes, $0.50 \mathrm{~mL} 30 \% \mathrm{H}_{2} \mathrm{O}_{2}$ (J.T. Baker) was then added, and the suspension was mixed for an additional 30 minutes. The suspension was centrifuged for 6 hours at $4500 \mathrm{rpm}$ (centrifuge: Allegra-22R, rotor: S4180). This was calculated to leave particles less than $50 \mathrm{~nm}$ in suspension. The supernatant was discarded and the wet solids were transferred to $6000-8000 \mathrm{MWCO}$ dialysis bags which were placed in a $4 \mathrm{~L}$ glass beaker with $0.01 \mathrm{M} \mathrm{NaCl}$. The solids were dialyzed for 7 days and the $\mathrm{NaCl}$ solution was changed at least once per day. The solids were extruded from the dialysis bags into two $200 \mathrm{~mL}$ centrifuge bottles and suspended in $150 \mathrm{~mL} \mathrm{MQ} \mathrm{H}_{2} \mathrm{O}$. These suspensions were mixed overnight to break up particle aggregates formed during dialysis. The suspensions were centrifuged for 5 minutes at $1000 \mathrm{rpm}$ and the supernatant decanted into two clean $200 \mathrm{~mL}$ centrifuge bottles. This supernatant phase now contained the $<2.0 \mu \mathrm{m}$ particle size fraction. The suspension was centrifuged 6 hours at $4500 \mathrm{rpm}$ and the supernatant was decanted and discarded to remove $>50 \mathrm{~nm}$ particles. The wet solids ( $50 \mathrm{~nm}$ to $2 \mu \mathrm{m}$ particles size) were transferred to a glass petri dish and dried for two weeks at $40^{\circ} \mathrm{C}$. A remarkable decrease in overall volume of the montmorillonite was observed after drying, presumably due to dehydration of the interlayer. A portion of the dried montmorillonite was resuspended in $\mathrm{MQ} \mathrm{H}_{2} \mathrm{O}$ to make a suspension with a montmorillonite concentration of $48.06 \mathrm{~g}_{\text {montmorillonite }} \mathrm{kg}^{-1}$ solution. This was used as a stock montmorillonite suspension. A small portion of the suspension was dried at $40^{\circ} \mathrm{C}$ and the particles were lightly ground then used for a surface area measurement. The particles had a surface area of $27.1 \mathrm{~m}^{2} \mathrm{~g}^{-1}$ which is near the reported value of $31.8 \mathrm{~m}^{2} \mathrm{~g}^{-1}$ (Clay Minerals Repository).

XRD patterns for all three solid phases were obtained on a PAD-V x-ray diffractometer (Figures 2.1-2.3). The observed spectra for each of the processed solid phases compares favorably with reference patterns from the ICDD. The diffractometer settings were as follows: $1 \mathrm{~mm}$ and $2 \mathrm{~mm}$ 
tube slit width, 0.3 and $0.2 \mathrm{~mm}$ detector slit width, $45 \mathrm{kV}$ voltage, $35 \mathrm{~mA}$ current, step scan with 0.02 step size, dwell time $1.0 \mathrm{~s}$.

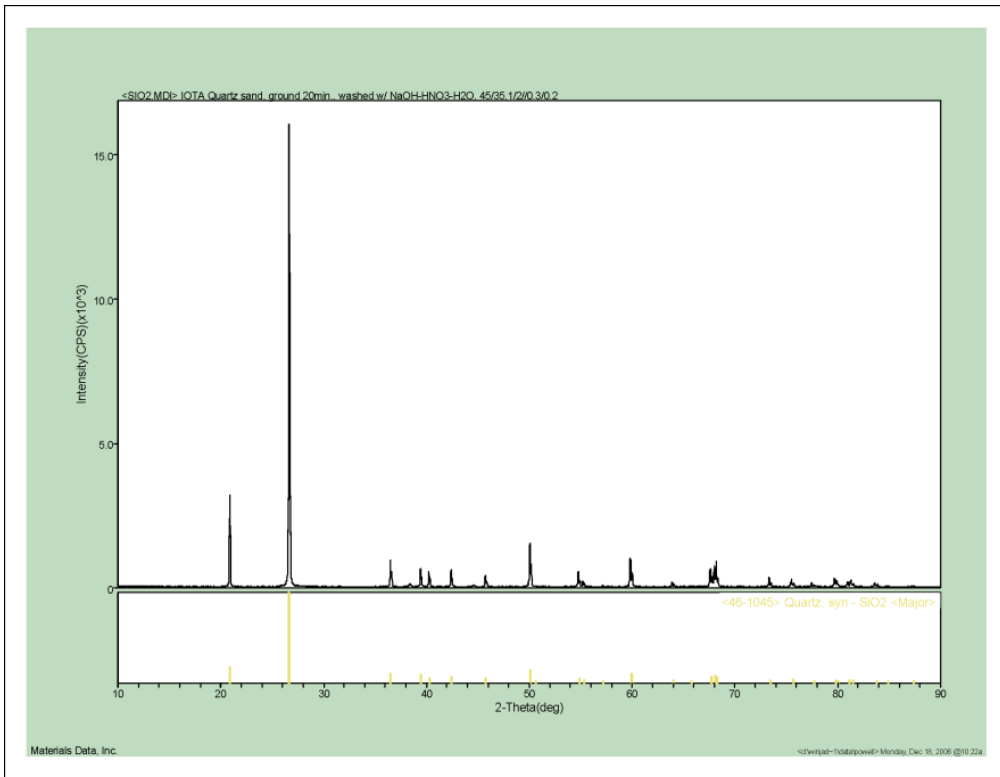

Figure 2.1: XRD pattern of milled and processed silica used in sorption experiments.

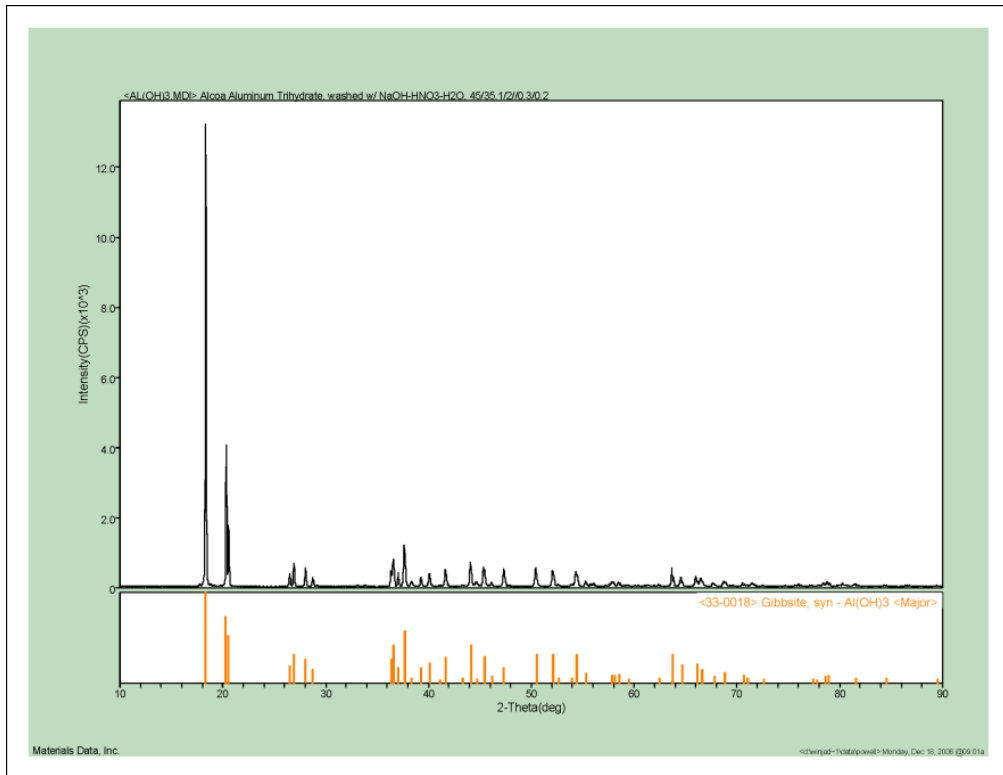

Figure 2.2: XRD pattern of processed gibbsite used in sorption experiments. 


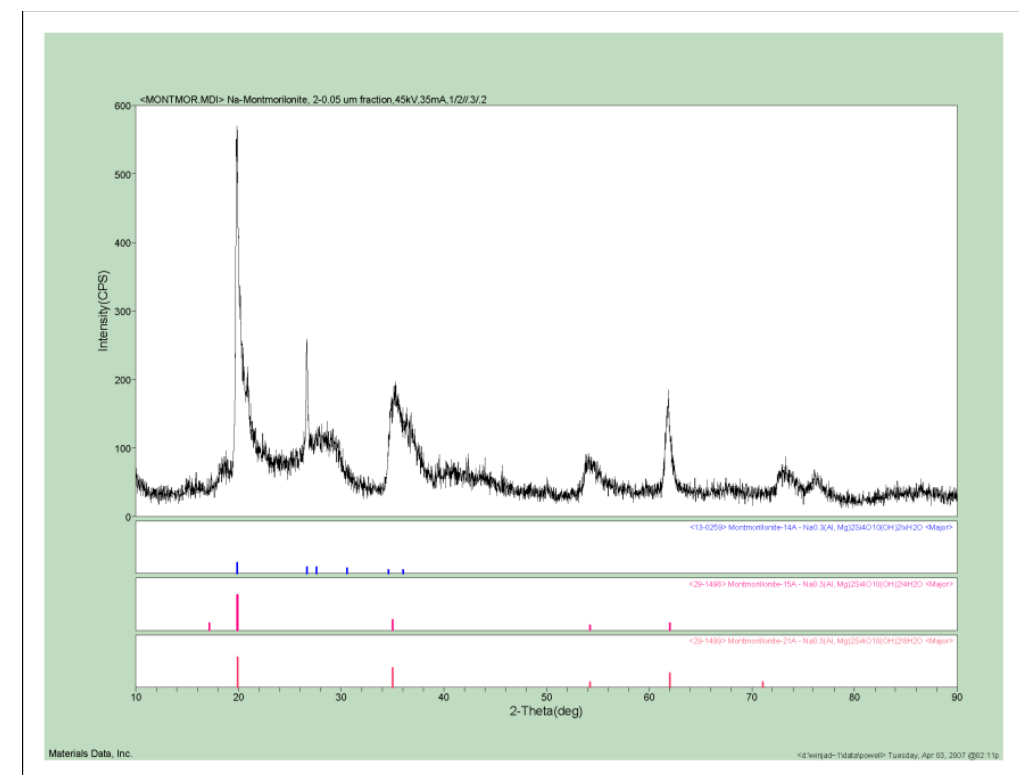

Figure 2.3: XRD pattern of processed montmorillonite used in sorption experiments.

\subsection{Plutonium Working Solution Preparation and Characterization}

\subsubsection{Pu Stock Solution}

A $1.2 \mu \mathrm{M} \mathrm{Pu}\left(\mathrm{NO}_{3}\right)_{4}$ stock solution in $1 \mathrm{M} \mathrm{HNO}_{3}$ containing $99.77 \%{ }^{238} \mathrm{Pu}, 0.16 \%{ }^{241} \mathrm{Pu}$, and $0.04 \%{ }^{239} \mathrm{Pu}$ by activity (Isotope Products) was used to prepare the Pu working solutions. The stock solution was purified by anion exchange prior to use to remove the ${ }^{241} \mathrm{Am}$ daughter from ${ }^{241} \mathrm{Pu}$ decay. A full description of the isotopic distribution is located in the Appendix B. Concentrations ${ }^{238} \mathrm{Pu}$ were determined on a Packard Tricarb 2550TR/XL Liquid Scintillation Analyzer in Ecolume (MP Biomedicals) cocktail.

\subsubsection{Pu Oxidation State Analysis}

The $\mathrm{Pu}$ concentration used here was too low to employ more traditional spectroscopic techniques to characterize Pu oxidation state distribution (Cleveland, 1979; Conradson et al., 1998). Instead, oxidation state analysis of the $\mathrm{Pu}$ working solution and effluent samples was performed using lanthanum fluoride coprecipitation and solvent extraction. The techniques reported here consider $\mathrm{Pu}(\mathrm{IV}), \mathrm{Pu}(\mathrm{V})$, and $\mathrm{Pu}(\mathrm{VI}) . \mathrm{Pu}(\mathrm{III})$ is not considered or quantified in the separation scheme as it will be unstable in the oxic, circumneutral $\mathrm{pH}$ solutions used in these experiments (Cleveland, 1979).

Separation of $\mathrm{Pu}$ oxidation state by lanthanum fluoride was based on the method described by Kobashi and Choppin (1988). The Pu concentration in the supernatant was determined by LSC and represents the $\mathrm{Pu}(\mathrm{V} / \mathrm{VI})$ fraction. The $\mathrm{Pu}(\mathrm{IV})$ fraction was calculated by difference. Separation of $\mathrm{Pu}$ oxidation states by solvent extraction was performed using $0.5 \mathrm{M}$ bis(ethylhexyl)-phosphoric acid (HDEHP) in xylene and 0.025 M 4-benzyol-3-methyl-1-phenyl-2pyrazolin-5-one (PMBP) in xylene as the extractants (Bertrand and Choppin, 1982; Foti and Freiling, 1964; Neu et al., 1994; Nitsche et al., 1988). The Pu oxidation state distribution in the 
working solution was determined using both HDEHP and PMBP as extractants. The error in the oxidation state distribution can be propagated from nuclear counting methods and is typically in the range of $1 \%$. An estimate of at least $5 \%$ error is recommended as these are inherently indirect methods for oxidation state analysis and therefore introduce the possibility of inducing redox changes during measurement.

\subsubsection{Pu(V) Working Solution Preparation}

To prepare a $\mathrm{Pu}(\mathrm{V})$ working solution, a small aliquot of the $1.2 \mu \mathrm{M} \mathrm{Pu}\left(\mathrm{NO}_{3}\right)_{4}$ stock solution was evaporated to dryness then dissolved in $0.5 \mathrm{~mL} 1.0 \mathrm{M} \mathrm{HCl} / 0.2 \mathrm{mM} \mathrm{KMnO}_{4}$ in a plastic vial. The vial was wrapped in $\mathrm{Al}$ foil and left for 8 hours to oxidize all $\mathrm{Pu}$ to $\mathrm{Pu}(\mathrm{VI})$. The solution was diluted approximately $200 \times$ with $5 \mathrm{mM} \mathrm{NaCl}$ to $\mathrm{pH} 2-3$. A $10 \mu \mathrm{L}$ aliquot of $0.01 \mathrm{M} \mathrm{MnCl}_{2}$ was added to precipitate any remaining permanganate. The $\mathrm{pH}$ was kept low $(<3)$ during this step to avoid coprecipitating Pu. The solution was then passed through a $100 \mathrm{~nm}$ nylon syringe filter into a Teflon bottle, adjusted to $\mathrm{pH} 3$ using $\mathrm{NaOH}$ and left for 5 days to allow autoreduction of $\mathrm{Pu}(\mathrm{VI})$ to $\mathrm{Pu}(\mathrm{V})$. The oxidation state purity of the working solution was verified prior to beginning each experiment (Table 2.1) and a fresh working solution was prepared for each set of experiments. The concentration and oxidation state distribution of these solutions did not change over the course of the experiment indicating the stability of $\mathrm{Pu}(\mathrm{V})$ at the trace levels used in these experiments.

Table 2.1 Pu Concentration and Oxidation State in $\mathrm{Pu}(\mathrm{V})$ Working Solutions

\begin{tabular}{|c|c|c|c|c|c|c|}
\hline $\begin{array}{c}\text { Experiment - Target Pu Ox. } \\
\text { State and Solid Phase }\end{array}$ & $\begin{array}{c}\text { Pu Conc. } \\
\mathrm{mol} \mathrm{L}^{-1}\end{array}$ & $\begin{array}{c}\text { Solv. } \\
\text { Extract. } \\
\text { Pu(IV) }\end{array}$ & $\begin{array}{c}\text { Solv. } \\
\text { Extract. } \\
\mathrm{Pu}(\mathrm{V})\end{array}$ & $\begin{array}{c}\text { Solv. } \\
\text { Extract. } \\
\text { Pu(VI) }\end{array}$ & $\begin{array}{c}\mathrm{LaF}_{3^{-}} \\
\text {Coprecip } \\
\mathrm{Pu}(\mathrm{III} / \mathrm{IV})\end{array}$ & $\begin{array}{c}\mathrm{LaF}_{3^{-}} \\
\text {Coprecip } \\
\mathrm{Pu}(\mathrm{V} / \mathrm{VI})\end{array}$ \\
\hline $\mathrm{Pu}(\mathrm{V})-\mathrm{Gibbsite} *$ & $5.90 \mathrm{E}-09$ & $1.1 \%$ & $92 \%$ & $6 \%$ & $1 \%$ & $99 \%$ \\
\hline $\mathrm{Pu}(\mathrm{V})-\mathrm{Silica} *$ & 5.90E-09 & $1.1 \%$ & $92 \%$ & $6 \%$ & $1 \%$ & $99 \%$ \\
\hline $\mathrm{Pu}(\mathrm{V})$-Gibbsite & $1.50 \mathrm{E}-09$ & $0.3 \%$ & $97 \%$ & $2 \%$ & $2 \%$ & $98 \%$ \\
\hline $\mathrm{Pu}(\mathrm{V})$-Silica & 7.90E-09 & $1.4 \%$ & $95 \%$ & $5 \%$ & $4 \%$ & $96 \%$ \\
\hline $\mathrm{Pu}(\mathrm{V})$-Montmorillonite* & 5.90E-09 & $0.6 \%$ & $96 \%$ & $2 \%$ & $2 \%$ & $96 \%$ \\
\hline $\mathrm{Pu}(\mathrm{V})$-Montmorillonite & 8.30E-09 & $0.6 \%$ & $96 \%$ & $1 \%$ & $0 \%$ & $100 \%$ \\
\hline
\end{tabular}

*Used in experiments where $\mathrm{CO}_{2}(\mathrm{~g})$ was removed

\subsubsection{Pu(IV) Working Solution Preparation}

New $\mathrm{Pu}(\mathrm{IV})$ working solutions were prepared for each experiment. $\mathrm{Pu}(\mathrm{IV})$ was prepared by transferring a small aliquot of the ${ }^{238} \mathrm{Pu}$ stock solution to a Teflon vial. The solution was heated until incipient dryness was reached followed by the addition of $0.1 \mathrm{M} \mathrm{HCl}$ (less than $1 \mathrm{~mL}$ ) along with $10 \mu \mathrm{L} 0.1 \mathrm{M} \mathrm{NaNO}_{2}$. To prevent precipitation of $\mathrm{Pu}(\mathrm{OH})_{4}(\mathrm{~s})$ and to keep $\mathrm{Pu}$ in the tetravalent oxidation state, the solution was maintained at $\mathrm{pH}<1$. The total volume was kept low to minimize adjustment of sample $\mathrm{pHs}$ following the addition of the $\mathrm{Pu}(\mathrm{IV})$ spike. The $\mathrm{Pu}$ concentration and oxidation state distribution of each $\mathrm{Pu}(\mathrm{IV})$ working solution was determined immediately prior to starting an experiment (Table 2.2). 
Table 2.2 Pu Concentration and Oxidation State in Pu(IV) Working Solutions

\begin{tabular}{ccccccc}
\hline $\begin{array}{c}\text { Experiment - Target Pu Ox. } \\
\text { State and Solid Phase }\end{array}$ & $\begin{array}{c}\text { Pu Conc. } \\
\text { mol L }\end{array}$ & $\begin{array}{c}\text { Solv. } \\
\text { Extract. } \\
\mathrm{Pu}(\mathrm{IV})\end{array}$ & $\begin{array}{c}\text { Solv. } \\
\text { Extract. } \\
\mathrm{Pu}(\mathrm{V})\end{array}$ & $\begin{array}{c}\text { Solv. } \\
\text { Extract. } \\
\mathrm{Pu}(\mathrm{VI})\end{array}$ & $\begin{array}{c}\mathrm{LaF}_{3^{-}} \\
\text {Coprecip } \\
\mathrm{Pu}(\mathrm{III} / \mathrm{IV})\end{array}$ & $\begin{array}{c}\mathrm{LaF}_{3^{-}} \\
\text {Coprecip } \\
\mathrm{Pu}(\mathrm{V} / \mathrm{VI})\end{array}$ \\
\hline \hline $\mathrm{Pu}(\mathrm{IV})-$ Gibbsite* & $1.21 \mathrm{E}-07$ & $96 \%$ & $2 \%$ & $1 \%$ & $98 \%$ & $2 \%$ \\
$\mathrm{Pu}(\mathrm{IV})-$ Silica* & $1.21 \mathrm{E}-07$ & $96 \%$ & $2 \%$ & $1 \%$ & $98 \%$ & $2 \%$ \\
$\mathrm{Pu}(\mathrm{IV})-$ Gibbsite & $1.30 \mathrm{E}-07$ & $95 \%$ & $3 \%$ & $2 \%$ & $99 \%$ & $1 \%$ \\
$\mathrm{Pu}(\mathrm{IV})-$ Silica & $1.30 \mathrm{E}-07$ & $95 \%$ & $3 \%$ & $2 \%$ & $99 \%$ & $1 \%$ \\
$\mathrm{Pu}(\mathrm{IV})-$ Montmorillonite* & $1.67 \mathrm{E}-07$ & $97 \%$ & $1 \%$ & $2 \%$ & $99 \%$ & $2 \%$ \\
$\mathrm{Pu}(\mathrm{IV})-$ Montmorillonite & $1.20 \mathrm{E}-07$ & $99 \%$ & $1 \%$ & $1 \%$ & $99 \%$ & $1 \%$ \\
\hline
\end{tabular}

*Used in experiments where $\mathrm{CO}_{2}(\mathrm{~g})$ was removed

\subsection{Sorption Edge Experimental Method}

Working suspensions of silica, gibbsite, and montmorillonite were prepared to yield a calculated surface area concentration of approximately $100 \mathrm{~m}^{2} \mathrm{~L}^{-1}$. A constant surface area in each solution allows for a more direct comparison of sorption properties. Batch sorption samples were prepared in acid-washed $15 \mathrm{~mL}$ polypropylene centrifuge tubes by mixing calculated amounts of $0.001 \mathrm{M} \mathrm{HCl}, 0.001 \mathrm{M} \mathrm{NaOH}, 0.1 \mathrm{M} \mathrm{NaCl}, \mathrm{MQ} \mathrm{H} \mathrm{H}_{2} \mathrm{O}$ (distilled-deionized water through Milli-Q system, $18.2 \mathrm{M} \Omega \mathrm{cm}$ resistivity), and an aliquot of the silica, gibbsite, or montmorillonite working suspension. The amount of $\mathrm{HCl}$ or $\mathrm{NaOH}$ was adjusted to achieve a desired $\mathrm{pH}$ and the amount of $\mathrm{NaCl}$ was adjusted to maintain a constant ionic strength of $0.01 \mathrm{M}$. The volumes of each solution/suspension used for each experimental system are listed in Appendix B. Although listed as volumes in Tables B1-B4, these values were used as "guides" and the mass of each solution for every sample was monitored gravimetrically to prevent inclusion of pipetting error into calculations. This was especially important when adding a $10 \mu \mathrm{L} \mathrm{Pu}(\mathrm{IV})$ spike. Samples were prepared across the $\mathrm{pH}$ range 4 to 10 . For experiments where $\mathrm{CO}_{2}(\mathrm{~g})$ was excluded, all solutions were prepared from $\mathrm{MQ} \mathrm{H}_{2} \mathrm{O}$ which had been boiled for one hour then cooled while purging the vessel headspace with $\mathrm{NaOH}$-scrubbed $\mathrm{N}_{2}(\mathrm{~g})$. All sample preparation and manipulation for $\mathrm{CO}_{2}(\mathrm{~g})$-free experiments was performed in a glovebox that was purged with $\operatorname{Ar}(\mathrm{g})$ to decrease the $\mathrm{CO}_{2}(\mathrm{~g})$ concentration then backfilled with $\mathrm{CO}_{2}(\mathrm{~g})$-free air (Ultra Zero Air) such that a constant $\mathrm{O}_{2}(\mathrm{~g})$ concentration was maintained in all experiments. Experiments performed under atmospheric conditions $\left(\mathrm{CO}_{2}(\mathrm{~g})\right.$-equilibrated $)$ were prepared as described above except $\mathrm{Na}_{2} \mathrm{CO}_{3}$ and $\mathrm{NaHCO}_{3}$ were added to ensure equilibration with atmospheric $\mathrm{CO}_{2}(\mathrm{~g})$. At $\mathrm{pH}$ values greater than 9 the total carbonate concentration was limited to less than $0.01 \mathrm{M}$ to maintain a constant ionic strength.

After preparing the initial suspensions for either $\mathrm{CO}_{2}(\mathrm{~g})$-free or $\mathrm{CO}_{2}(\mathrm{~g})$-equilibrated experiments, suspensions were spiked with either a $\mathrm{Pu}(\mathrm{IV})$ or $\mathrm{Pu}(\mathrm{V})$ working solution and the $\mathrm{pH}$ adjusted to the target $\mathrm{pH}$ using dilute $\mathrm{HCl}$ or $\mathrm{NaOH}$. The $\mathrm{pH}$ of each suspension was measured with an Orion Ross semi-micro electrode calibrated with standard $\mathrm{pH}$ buffers on an Orion 420A meter. After adjusting the $\mathrm{pH}$ to the target value, the samples were transferred to a shaking table and mixed at $150 \mathrm{rpm}$ about their longitudinal axis. It is important to note that the shaker table was located outside of the glovebox so samples prepared under $\mathrm{CO}_{2}(\mathrm{~g})$ free conditions were mixed outside of the glovebox. Although the samples were sealed, $\mathrm{CO}_{2}(\mathrm{~g})$ diffusion into the suspension 
became significant at longer time intervals ( $>3$ days). The diffusion of $\mathrm{CO}_{2}(\mathrm{~g})$ caused a notable $\mathrm{pH}$ decrease due to formation of bicarbonate during equilibration off the suspension with $\mathrm{CO}_{2}(\mathrm{~g})$.

At various time intervals, the $\mathrm{pH}$ (and on some occasions $\mathrm{E}_{\mathrm{H}}$ ) was measured. The aqueous $\mathrm{Pu}$ concentration was determined by centrifuging $1.8 \mathrm{~mL}$ of the suspension at $10,000 \mathrm{rpm}$ for 2 hours. This centrifuge speed and time was calculated to remove particles greater than $30 \mathrm{~nm}$ from the supernatant. A $1.0 \mathrm{~mL}$ aliquot of the supernatant was mixed with $5 \mathrm{~mL}$ Ecolume LSC cocktail for Pu determination via LSC. In selected cases, additional aliquots were removed and passed through $3 \mathrm{k}$ Molecular Weight Cut-Off (MWCO) filters to verify that the centrifugation scheme removed the selected particle size fraction. The Pu oxidation state distribution was measured in the filtrate using the techniques described above.

\subsection{Surface Complexation Modeling}

To remain consistent with the current modeling efforts and databases employed in UGTA project, the data were modeled using a non-electrostatic surface complexation model. The computer program FIT4FD was used in all modeling efforts. FIT4FD was created by modifying the program FITEQL 4.0 (Herbelin and Westall, 1994) to allow for rapid data input and analysis of complex datasets. The specific details of each modeling exercise are discussed in Chapters 4 and 5 .

\section{SORPTION EDGE EXPERIMENT RESULTS AND DISCUSSION}

\subsection{Pu(IV) and Pu(V) Control (Solid-free) Solutions}

\subsection{1 $\mathrm{Pu}(\mathrm{V})$ Control Solutions}

Solid-free control samples were included in each sorption experiment. In addition to determining aqueous $\mathrm{Pu}$ in each sample, the oxidation state of the aqueous $\mathrm{Pu}$ was determined after 2 hours, 24 hours, and 60 days. The aqueous Pu fraction was determined via centrifugation (Figure 3.1). The oxidation state was determined using $\mathrm{LaF}_{3}$-coprecipitation (Figure 3.2). With the exception of the final sampling event at high $\mathrm{pH}, \mathrm{Pu}(\mathrm{V})$ solutions remained in the aqueous phase throughout the experiment. $\mathrm{The} \mathrm{Pu}(\mathrm{V})$ solutions remained predominantly $\mathrm{Pu}(\mathrm{V})$ throughout the experiment. The only exception appears to be the high $\mathrm{pH}$ system, which also showed a loss of total aqueous $\mathrm{Pu}$ after 60 days. The data suggest that some $\mathrm{Pu}$ precipitation occurred at this $\mathrm{pH}$. 


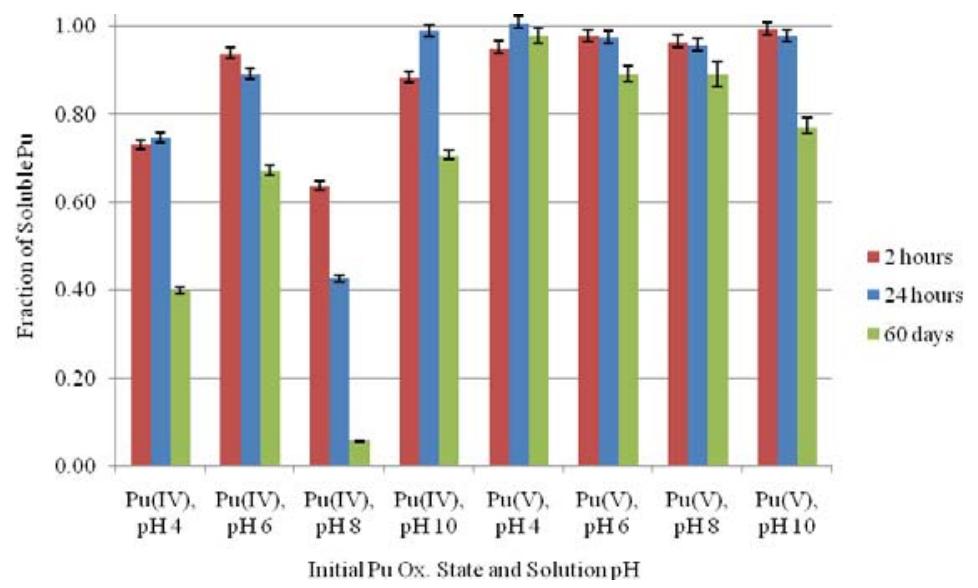

Figure 3.1: Fraction of soluble $\mathrm{Pu}$ in $\mathrm{Pu}(\mathrm{IV})$ and $\mathrm{Pu}(\mathrm{V})$ control solutions (no solid phase present, $\mathrm{CO}_{2}(\mathrm{~g})-$ equilibrated system).

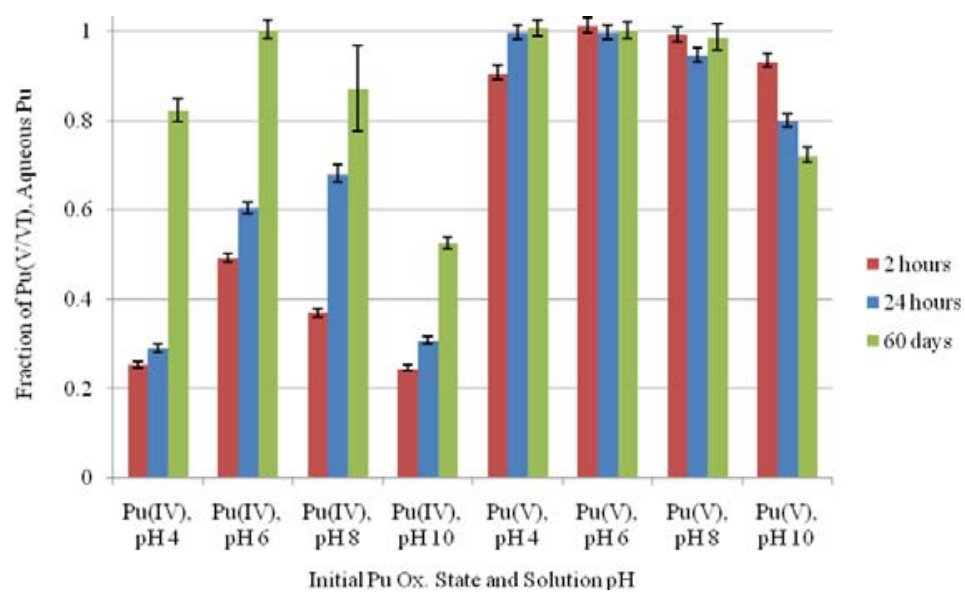

Figure 3.2: Oxidation state distribution of aqueous $\mathrm{Pu}$ in $\mathrm{Pu}(\mathrm{IV})$ and $\mathrm{Pu}(\mathrm{V})$ control solutions (no solid phase present, $\mathrm{CO}_{2}(\mathrm{~g})$-equilibrated system). Note: error bars account for nuclear counting statistics only.

\subsection{2 $\mathrm{Pu}(\mathrm{IV})$ Control Solutions}

The $\mathrm{Pu}(\mathrm{IV})$ solutions showed a considerable loss of $\mathrm{Pu}$ from the aqueous phase. This is due to either sorption of $\mathrm{Pu}$ to the vessel walls or precipitation of $\mathrm{Pu}(\mathrm{OH})_{4}(\mathrm{~s})$. Using the solubility product for $\mathrm{Pu}(\mathrm{OH})_{4}(\mathrm{~s})$ reported by Neck and Kim (2001), the $\mathrm{Pu}(\mathrm{IV})$ concentration should be limited to approximately $10^{-11} \mathrm{M}$. However, solubility experiments frequently observe aqueous $\mathrm{Pu}$ concentrations ranging from $10^{-11}$ to $10^{-7} \mathrm{M}$. The discrepancy is due to oxidation of $\mathrm{Pu}(\mathrm{IV})$ to $\mathrm{Pu}(\mathrm{V})$ and mischaracterization of colloidal $\mathrm{Pu}$ as an aqueous species. Neck et al. (2007) proposed that $\mathrm{Pu}(\mathrm{V})$ is formed through oxidation of $\mathrm{PuO}_{2}(\mathrm{~s})$ by dissolved oxygen to form the hydrous oxide $\mathrm{PuO}_{2+\mathrm{x}}$. They reported that $\mathrm{Pu}$ polymers will be present at a constant level of $\log [\mathrm{Pu}(\mathrm{IV})]_{\mathrm{coll}}=-8.3 \pm 1.0$. Recently, Soderholm et al. (2008) observed monodispere, nanometer sized $\mathrm{Pu}$ "nanoclusters" which persisted in solution indefinitely. Colloids of this nature are not expected in this work due to the relatively low Pu concentration $\left(10^{-10} \mathrm{M}\right)$. However, formation 
of some colloidal $\mathrm{Pu}(\mathrm{IV})$ cannot be altogether discounted. In light of these observations, there are three main factors that must be considered in the analysis of the $\mathrm{Pu}(\mathrm{IV})$ control solutions:

1. Sorption of $\mathrm{Pu}$ to the vial walls

2. Oxidation of $\mathrm{Pu}(\mathrm{IV})$ to $\mathrm{Pu}(\mathrm{V})$ mediated by dissolved oxygen

3. Formation of colloidal $\mathrm{Pu}(\mathrm{IV})$ and possible mischaracterization as aqueous $\mathrm{Pu}$

After 2 hours, the aqueous $\mathrm{Pu}$ concentration varied with $\mathrm{pH}$. The lowest values were observed at pH 8. A steady decrease in the aqueous Pu concentration was observed for each solution over time. Sorption to the vial walls is expected to occur rapidly. Therefore, the steady loss of aqueous $\mathrm{Pu}$ over 60 days is not indicative of sorption to vial walls. Oxidation state analysis of aqueous $\mathrm{Pu}$ revealed that even after 2 hours, there was a significant fraction of $\mathrm{Pu}(\mathrm{V})$ present. As shown in Table 2.2, the $\mathrm{Pu}(\mathrm{IV})$ solutions were initially $>95 \% \mathrm{Pu}(\mathrm{IV})$. Therefore, the observation of $\mathrm{Pu}(\mathrm{V} / \mathrm{VI})$ in each solution indicates oxidation of $\mathrm{Pu}(\mathrm{IV})$ to $\mathrm{Pu}(\mathrm{V} / \mathrm{VI})$, presumably by dissolved oxygen. The fraction of aqueous $\mathrm{Pu}$ characterized as $\mathrm{Pu}(\mathrm{V} / \mathrm{VI})$ increased over time (Figure 3.2). However, oxidation state data were collected only on the aqueous $\mathrm{Pu}$ fraction, not the total $\mathrm{Pu}$. Based on Figure 3.1, there was a corresponding decrease in the total aqueous $\mathrm{Pu}$ in the system. Since the concentration and oxidation state distribution of the $\mathrm{Pu}(\mathrm{V})$ solutions remained constant, it can be logically assumed that the loss of $\mathrm{Pu}$ observed in the $\mathrm{Pu}(\mathrm{IV})$ solutions can be attributed to $\mathrm{Pu}(\mathrm{IV})$ precipitation. The fraction of $\mathrm{Pu}(\mathrm{V} / \mathrm{VI})$ as a function of the total $\mathrm{Pu}$ concentrations can be calculated by subtracting the concentration of "lost" $\mathrm{Pu}$ and the concentration of measured $\mathrm{Pu}(\mathrm{III} / \mathrm{IV}$ ) from the total $\mathrm{Pu}$ concentrations (Figure 3.3). Except for the $\mathrm{pH} 8$ solution, there was a constant increase in the total $\mathrm{Pu}(\mathrm{V})$ in each solution over time. Therefore, despite the initial decrease in the aqueous $\mathrm{Pu}$ concentration versus time (Figure 3.1), there was an overall increase in $\mathrm{Pu}(\mathrm{V} / \mathrm{VI})$ over time. Formation of aqueous $\mathrm{Pu}(\mathrm{V})$ from $\mathrm{Pu}(\mathrm{IV})$ solutions is vitally important in explaining the observed sorption behavior in this work.

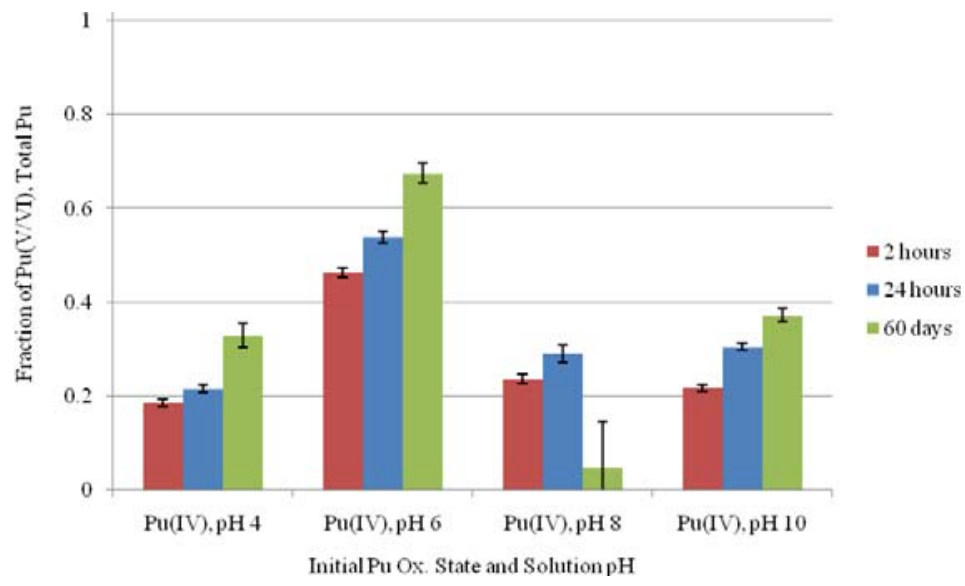

Figure 3.3: Fraction of $\mathrm{Pu}(\mathrm{V} / \mathrm{VI})$ referenced to total $\mathrm{Pu}$ in $\mathrm{Pu}(\mathrm{IV})$ control solutions (no solid phase present, $\mathrm{CO}_{2}(\mathrm{~g})$ equilibrated system). 


\subsection{Pu(IV) and Pu(V) Sorption to Gibbsite}

Sorption edges for $\mathrm{Pu}(\mathrm{V})$ and $\mathrm{Pu}(\mathrm{IV})$ on gibbsite are shown in Figure 3.4. Data for sampling intervals of 24 hours, 62 days, and 306 days are represented by squares, diamonds, and triangles, respectively, in both $\mathrm{Pu}(\mathrm{IV})$ and $\mathrm{Pu}(\mathrm{V})$ systems. Open symbols were used to represent $\mathrm{Pu}$ sorption in $\mathrm{CO}_{2}(\mathrm{~g})$ free systems. The $\mathrm{CO}_{2}(\mathrm{~g})$-free data are available for the 24 hours sampling event only. Diffusion of $\mathrm{CO}_{2}(\mathrm{~g})$ into the $\mathrm{CO}_{2}(\mathrm{~g})$-free samples limited the reliability of data obtained from longer sampling intervals.
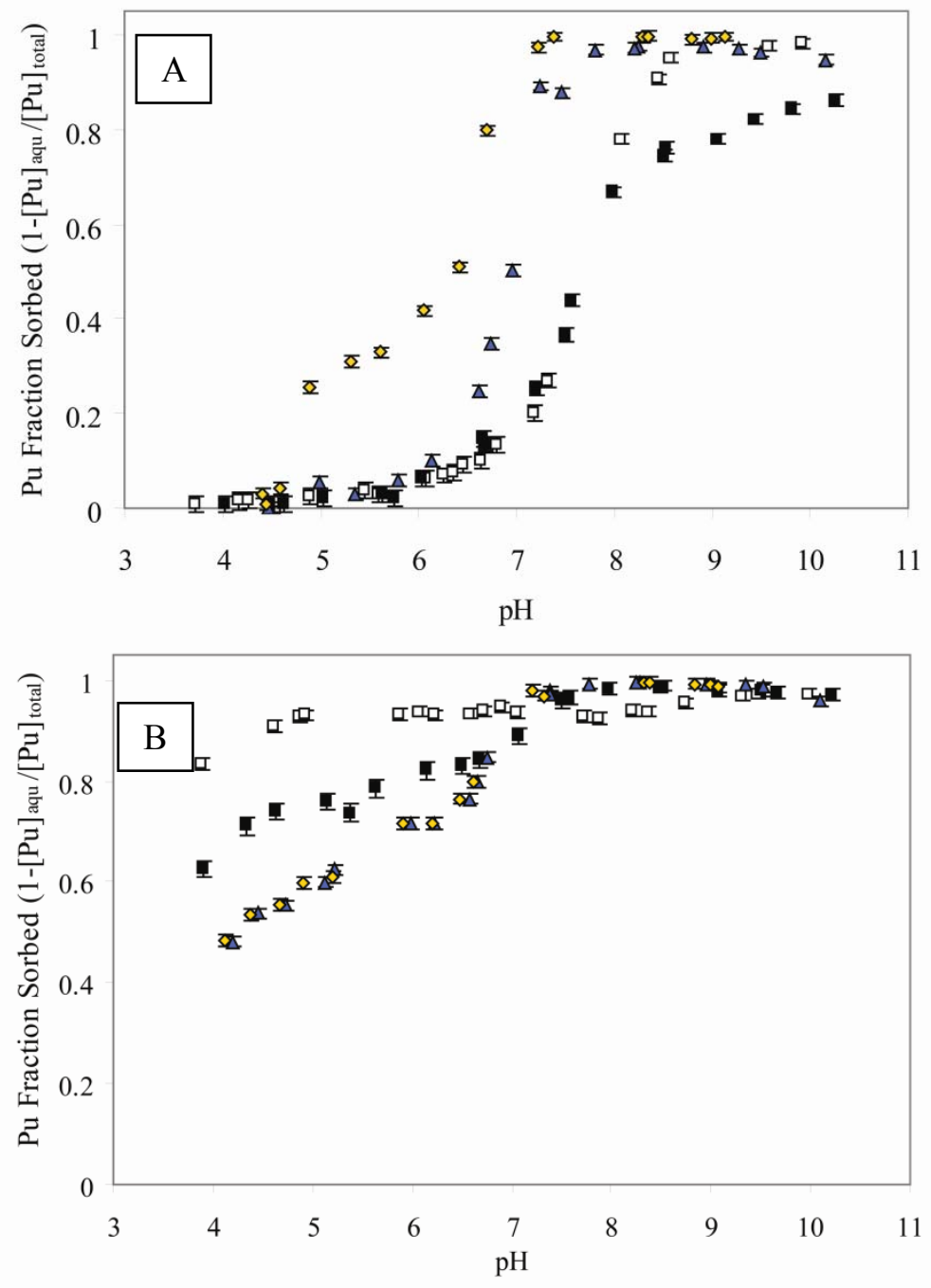

Figure 3.4: Sorption of (A) $\mathrm{Pu}(\mathrm{V})$ and (B) $\mathrm{Pu}(\mathrm{IV})$ to gibbsite. Data plotted after 24 hours (squares), 62 days (triangles), and 306 days (diamonds). Open squares represent systems where atmospheric $\mathrm{CO}_{2}(\mathrm{~g})$ was excluded.

In both $\mathrm{Pu}$ oxidation state samples, the fraction sorbed increased with $\mathrm{pH}$. The sorption behavior as a function of $\mathrm{pH}$ is due to changing $\mathrm{Pu}(\mathrm{IV})$ and $\mathrm{Pu}(\mathrm{V})$ solution species as well as the 
protonation and deprotonation of the surface hydroxyl groups $(\mathrm{AlOH})$. In acidic solutions, the aluminol sites on the gibbsite surface will be protonated $\left(\mathrm{AlOH}_{2}^{+}\right)$, giving the surface and overall net positive charge. As the $\mathrm{pH}$ of the solution increases, the aluminol sites depronate to form $\mathrm{AlOH}$ and $\mathrm{AlO}^{-}$. Therefore, the surface transitions to having a net negative charge in basic solutions. The $\mathrm{pH}$ at which the net surface charge is zero is called the point of zero charge. This occurs around $\mathrm{pH} 8$ to 9 for gibbsite (Sposito, 1989). This changing surface charge has a profound effect on sorption of charged ions such as $\mathrm{Pu}(\mathrm{V})$. At low $\mathrm{pH}$ values, $\mathrm{Pu}(\mathrm{V})$ is predominantly present as the dioxycation, $\mathrm{PuO}_{2}{ }^{+}$. Due to the net positive surface charge carried by the gibbsite in acidic solutions, cationic $\mathrm{PuO}_{2}{ }^{+}$is repelled by the surface and sorption is negligible (Figure 3.4a, 24 hours). The predominant forms of $\mathrm{Pu}(\mathrm{IV})$ under environmental conditions are the solution species $\mathrm{Pu}(\mathrm{OH})_{4}(\mathrm{aq})$ and the insoluble hydrolysis product $\mathrm{Pu}(\mathrm{OH})_{4}(\mathrm{~s})$. As demonstrated by the strong hydrolysis of $\mathrm{Pu}(\mathrm{IV})$ even under acidic conditions, $\mathrm{Pu}(\mathrm{IV})$ is strongly attracted to aluminol surface sites and the neutrally charged $\mathrm{Pu}(\mathrm{OH})_{4}(\mathrm{aq})$ species is not repelled by the mineral surface. This allows for strong sorption of $\mathrm{Pu}(\mathrm{IV})$ even at low $\mathrm{pH}$ values (Figure 3.4b).

The effect of carbonate was only observed in $\mathrm{Pu}(\mathrm{V})$ samples. Sorption of $\mathrm{Pu}(\mathrm{V})$ becomes significant at circumneutral $\mathrm{pH}$ values where the gibbsite surface maintains a neutral or net negative surface charge and where the free $\mathrm{Pu}(\mathrm{V}) \mathrm{O}_{2}{ }^{+}$cation begins to hydrolyze to $\mathrm{Pu}(\mathrm{V}) \mathrm{O}_{2} \mathrm{OH}(\mathrm{aq})$. At approximately $\mathrm{pH} 8$, the effects of carbonate on $\mathrm{Pu}(\mathrm{V})$ sorption can be observed. While sorption of $\mathrm{Pu}(\mathrm{V})$ steadily increases in the $\mathrm{CO}_{2}(\mathrm{~g})$-free system, a marked diversion in the sorption behavior was observed in the $\mathrm{CO}_{2}(\mathrm{~g})$-equilibrated system. This is due to the formation of anionic plutonyl-carbonate species such as $\mathrm{PuO}_{2} \mathrm{CO}_{3}{ }^{-}$which have a higher affinity for the aqueous phase. Similar behavior at high $\mathrm{pH}$ values was not observed for the $\mathrm{Pu}(\mathrm{IV})$ systems. Formation of $\mathrm{Pu}(\mathrm{IV})$-carbonates requires relatively high carbonate concentrations as the strength of $\mathrm{Pu}(\mathrm{IV})$ hydrolysis is greater than the strength of carbonate complexation.

There is a notable difference in the $\mathrm{Pu}(\mathrm{IV}) \mathrm{CO}_{2}(\mathrm{~g})$-free and $\mathrm{CO}_{2}(\mathrm{~g})$-equilibrated experiments at low $\mathrm{pH}$ values. This appears to be an experimental artifact due to the oxidation of $\mathrm{Pu}(\mathrm{IV})$ to $\mathrm{Pu}(\mathrm{V})$. When preparing these suspensions, calculated amounts of acid and base were added to each suspension to achieve a desired $\mathrm{pH}$. In the case of $\mathrm{Pu}(\mathrm{IV})$, the exact acid concentration of the stock solution was not known due to the repeated evaporation and re-dissolution of the solution. As a result, insufficient base was initially added to reach the desired $\mathrm{pH}$ and several of the $\mathrm{Pu}(\mathrm{IV})$ suspensions remained at an acidic $\mathrm{pH}$ for as much as 30 minutes. As shown in the $\mathrm{Pu}(\mathrm{IV})$ control solutions, some oxidation of $\mathrm{Pu}(\mathrm{IV})$ to $\mathrm{Pu}(\mathrm{V})$ occurs in acidic and neutral $\mathrm{pH}$ solutions at trace $\mathrm{Pu}$ concentrations. Over the time at which these samples remained in an acidic solution, some $\mathrm{Pu}(\mathrm{V})$ may have formed which would not readily sorb to gibbsite at low $\mathrm{pH}$. The rate of these changes cannot be predicted using current thermodynamic and kinetic data. However, it can be stated that the differences in the $\mathrm{Pu}(\mathrm{IV})$ datasets under $\mathrm{CO}_{2}(\mathrm{~g})$-free and $\mathrm{CO}_{2}(\mathrm{~g})$-equilibrated conditions at low $\mathrm{pH}$ values are likely due to oxidation of $\mathrm{Pu}(\mathrm{IV})$ to $\mathrm{Pu}(\mathrm{V})$ during sample preparation. The formation of aqueous $\mathrm{Pu}(\mathrm{V})$ was verified in $\mathrm{Pu}(\mathrm{IV})$ suspensions in the $\mathrm{CO}_{2}(\mathrm{~g})$-equilibrated dataset. It is also noteworthy that similar behavior was observed for the $\mathrm{Pu}(\mathrm{IV})$ systems in silica suspensions (discussed in Section 3.3). 
The $\mathrm{Pu}(\mathrm{IV})$ and $\mathrm{Pu}(\mathrm{V})$ data in $\mathrm{CO}_{2}(\mathrm{~g})$-equilibrated systems are plotted together in Figure 3.5. Sorption of $\mathrm{Pu}(\mathrm{V})$ to gibbsite increased as a function of time. This is proposed to be due to surface mediated reduction of $\mathrm{Pu}(\mathrm{V})$ to $\mathrm{Pu}(\mathrm{IV})$. The slope of the sorption edge decreases and appears to more closely resemble that of $\mathrm{Pu}(\mathrm{IV})$. There is no significant change in the $\mathrm{Pu}(\mathrm{IV})$ data between 62 and 300 days, indicating the system had reached a steady state. The $\mathrm{Pu}(\mathrm{V})$ sorption edge had drifted between 62 and 300 days indicating the system had not reached steady state. Presumably, the $\mathrm{Pu}(\mathrm{V})$ sorption edge would eventually align with the $\mathrm{Pu}(\mathrm{IV})$ sorption edge. It is unclear what the identity of the reductant in this system is. However, based upon the known thermodynamic favorability of $\mathrm{Pu}(\mathrm{IV})$ hydroxide species, a plausible hypothesis is that reduction of $\mathrm{Pu}(\mathrm{V})$ is based upon a Nerstian behavior where the free energy of the $\mathrm{Pu}(\mathrm{IV})$ surface species sufficiently energetically favorable that reduction of $\mathrm{Pu}(\mathrm{V})$ to $\mathrm{Pu}(\mathrm{IV})$ can be facilitated by water. An alternate hypothesis is that light or alpha particle induced peroxide formation may result in the reduction of $\mathrm{Pu}(\mathrm{V})$ to $\mathrm{Pu}(\mathrm{IV})$. Reduction of $\mathrm{Pu}(\mathrm{V})$ to $\mathrm{Pu}(\mathrm{IV})$ on a variety of mineral surfaces has been observed (Keeney-Kennicutt and Morse, 1985; Penrose et al., 1987; Powell et al., 2006; Powell et al., 2004; Powell et al., 2005; Sanchez et al., 1985). Most notably, Pu(V) reduction to $\mathrm{Pu}(\mathrm{IV})$ was observed on surfaces expected to be either oxidizing or non-reactive such as pyrolusite $\left(\delta-\mathrm{MnO}_{2}\right)$, tuff ( $\mathrm{Pu}$ predominantly associated with ranciete/Mn(IV) phase), hematite $\left(\alpha-\mathrm{Fe}_{2} \mathrm{O}_{3}\right)$, goethite $(\alpha-\mathrm{FeOOH})$, and silica $\left(\mathrm{SiO}_{2}\right)$ (Powell et al., 2006; Powell et al., 2005). In those studies reduction of $\mathrm{Pu}(\mathrm{V})$ was verified using direct (XANES) and indirect (solvent extraction) methods.

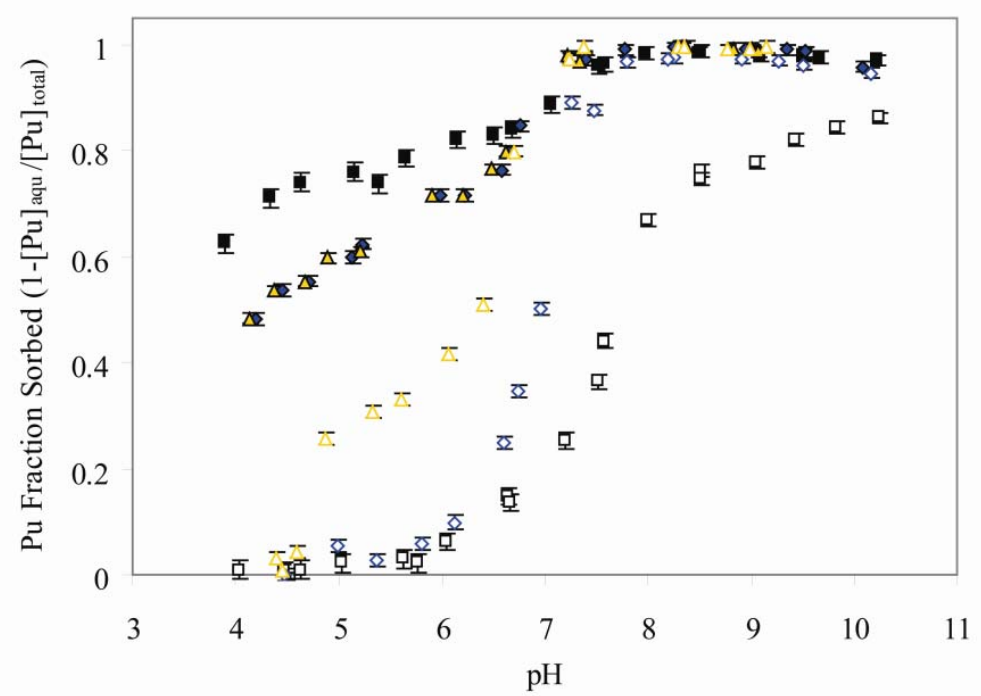

Figure 3.5: $\mathrm{Pu}(\mathrm{IV})$ (closed symbols) and $\mathrm{Pu}(\mathrm{V})$ (open symbols) sorption to gibbsite at 24 hours (squares), 62 days (diamonds), 300 days (triangles) in $\mathrm{CO}_{2}(\mathrm{~g})$-equilibrated solutions.

Interestingly, there was an increase in the aqueous $\mathrm{Pu}$ concentration in $\mathrm{Pu}(\mathrm{IV})$ samples between 24 hours and 62 days. Therefore, $\mathrm{Pu}$ initially sorbed as $\mathrm{Pu}(\mathrm{IV})$ desorbed over time in the $\mathrm{pH}$ range 4 to 7 . This is likely due to reoxidation of sorbed $\mathrm{Pu}(\mathrm{IV})$ to aqueous $\mathrm{Pu}(\mathrm{V})$. Surface mediated reduction of $\mathrm{Pu}(\mathrm{V})$ to $\mathrm{Pu}(\mathrm{IV})$ as discussed above is affected by $\mathrm{pH}$. Powell et al. (2005) found a -0.2 and -0.4 order dependence on the hydrogen ion concentration for the rate of $\mathrm{Pu}(\mathrm{V})$ reduction on goethite and hematite, respectively. Therefore, reduction of $\mathrm{Pu}(\mathrm{V})$ was expected to 
be more favored with increasing $\mathrm{pH}$. Conversely, at low $\mathrm{pH}$ values where a significant fraction of $\mathrm{Pu}$ is in the aqueous phase, $\mathrm{Pu}(\mathrm{V})$ is expected to be the dominant aqueous phase species. This is consistent with the observation of $\mathrm{Pu}(\mathrm{V})$ as the stable aqueous oxidation state in slightly acidic to neutral solutions including ocean and lake water and suspensions from $\mathrm{Pu}(\mathrm{IV})$ solubility experiments. Additionally, in all Pu sorption experiments where the oxidation state of the aqueous $\mathrm{Pu}$ fraction in a solid suspension was measured, $\mathrm{Pu}(\mathrm{V})$ was found to be the dominant oxidation state (Banik et al., 2007; Keeney-Kennicutt and Morse, 1985; Penrose et al., 1987; Powell et al., 2006; Powell et al., 2005; Powell et al., 2008; Sanchez et al., 1985). This was found to be the case for this work as well. Selected samples from the $\mathrm{Pu}(\mathrm{IV})$ experiments were analyzed after 6 days and after 62 days. The aqueous phase was separated by centrifugation and $\mathrm{Pu}$ oxidation state determined using $\mathrm{LaF}_{3}$-coprecipitation. The data (Table 3.1) clearly show that $\mathrm{Pu}(\mathrm{V})$ is the predominant aqueous phase oxidation state. $\mathrm{Pu}$, which initially sorbed as $\mathrm{Pu}(\mathrm{IV})$ repartitioned to the aqueous phase as $\mathrm{Pu}(\mathrm{V})$ over time. This is consistent with the observed behavior of the control (solid phase free) $\mathrm{Pu}(\mathrm{IV})$ and $\mathrm{Pu}(\mathrm{V})$ solutions. Assuming that the majority of sorbed $\mathrm{Pu}$ was $\mathrm{Pu}(\mathrm{IV})$, these $\mathrm{Pu}(\mathrm{IV})$-gibbsite suspensions at 62 and 306 days represent an equilibrium state with regard to all facets of Pu geochemistry including sorption, precipitation, and redox chemistry. The weakly sorbing gibbsite allows for a system to be maintained where significant and measureable quantities of aqueous phase $\mathrm{Pu}(\mathrm{V})$ and solid phase $\mathrm{Pu}(\mathrm{IV})$ are in equilibrium. This presents a very unique modeling opportunity that will be further explored in Chapter 5.

Table 3.1: Oxidation State Analysis of $\mathrm{Pu}(\mathrm{IV})$-gibbsite $\mathrm{CO}_{2}(\mathrm{~g})$-equilibrated suspensions determined via $\mathrm{LaF}_{3}$-coprecipitation.

\begin{tabular}{cccc}
\hline Sample $\mathrm{pH}$ & Fraction Sorbed & Fraction $\mathrm{Pu}(\mathrm{III} / \mathrm{IV})$ & Fraction $\mathrm{Pu}(\mathrm{V} / \mathrm{VI})$ \\
\hline \hline After 6 days & & & \\
4.3 & 0.60 & $0.02 \pm 0.03$ & $0.98 \pm 0.03$ \\
6.5 & 0.84 & $0.02 \pm 0.05$ & $0.98 \pm 0.05$ \\
After 62 days & & & \\
4.5 & 0.54 & $0.01 \pm 0.01$ & $0.99 \pm 0.01$ \\
6.6 & 0.78 & $0.05 \pm 0.02$ & $0.95 \pm 0.01$ \\
9.5 & 0.99 & $0.00 \pm 0.07$ & $1.00 \pm 0.07$ \\
\hline
\end{tabular}

\subsection{Pu(IV) and Pu(V) Sorption to Silica}

As with the gibbsite suspensions, $\mathrm{Pu}$ sorption to silica generally increased with $\mathrm{pH}$ for both $\mathrm{Pu}(\mathrm{IV})$ and $\mathrm{Pu}(\mathrm{V})$ (Figure 3.6). This is due to electrostatic interactions with silanol ( $\mathrm{SiOH})$ surface sites, rather than the aluminol surface. There was a notable difference in the low $\mathrm{pH}$ $\mathrm{Pu}(\mathrm{IV})$ samples in $\mathrm{CO}_{2}(\mathrm{~g})$ and $\mathrm{CO}_{2}(\mathrm{~g})$-equilibrated suspensions after 24 hours. As with the $\mathrm{Pu}(\mathrm{IV})$-gibbsite systems, this difference is believed to be due to oxidation of $\mathrm{Pu}(\mathrm{IV})$ to $\mathrm{Pu}(\mathrm{V})$ during neutralization of the $\mathrm{Pu}(\mathrm{IV})$ working solution. However, this difference was found to be negligible at later sampling intervals as the data for both $\mathrm{CO}_{2}(\mathrm{~g})$-free (data not shown) and $\mathrm{CO}_{2}(\mathrm{~g})$-equilibrated systems were similar after 62 days for all $\mathrm{Pu}$-silica systems (including $\mathrm{Pu}(\mathrm{V})$ samples). 

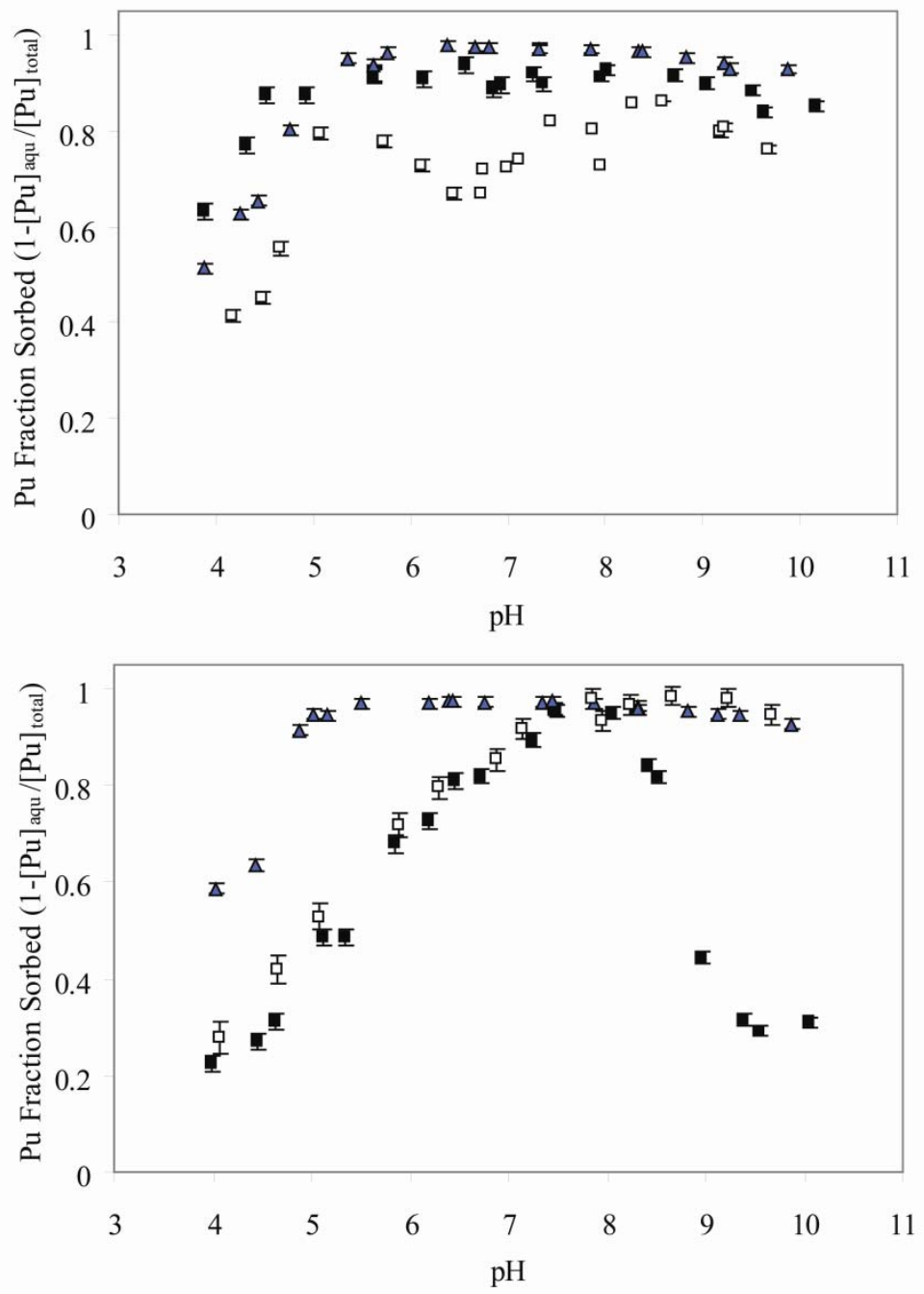

Figure 3.6: Sorption of (A) Pu(IV) and (B) Pu(V) to silica at 24 hours ( $\square, \boldsymbol{\square})$ and 62 days ( $\mathbf{\Delta})$. Open symbols represent systems where atmospheric $\mathrm{CO}_{2}(\mathrm{~g})$ was excluded.

The $\mathrm{Pu}(\mathrm{IV})$ samples showed significant changes in partitioning between 24 hours and 62 days $\left(\mathrm{CO}_{2}(\mathrm{~g})\right.$-equilibrated samples). Between $\mathrm{pH} 5$ and 9 , the fraction of $\mathrm{Pu}$ sorbed was $\sim 90 \%$ after 24 hours and increased to greater than $95 \%$ after 62 days. Due to the low aqueous Pu concentration, oxidation state analysis of the aqueous phase could not be performed. In $\mathrm{pH} 4$ to 5 suspensions, a slight desorption of $\mathrm{Pu}$ was observed between the 24 hour and 62 days. Measurement of the oxidation state distribution of the aqueous $\mathrm{Pu}$ indicated that oxidized $\mathrm{Pu}(\mathrm{V} / \mathrm{VI})$ was the predominant oxidation state (Table 3.2). The observed oxidation of $\mathrm{Pu}$ to aqueous $\mathrm{Pu}(\mathrm{V})$ is proposed to be responsible for the slight "desorption" of Pu between 24 hours and 62 days between $\mathrm{pH} 4$ and 5 . 
Table 3.2: Oxidation State Analysis of $\mathrm{Pu}(\mathrm{IV})$-silica $\mathrm{CO}_{2}(\mathrm{~g})$-equilibrated suspensions determined via $\mathrm{LaF}_{3}$-coprecipitation.

\begin{tabular}{cccc}
\hline Sample $\mathrm{pH}$ & $\mathrm{Pu}$ Fraction Sorbed & Fraction $\mathrm{Pu}(\mathrm{III} / \mathrm{IV})$ & Fraction $\mathrm{Pu}(\mathrm{V} / \mathrm{VI})$ \\
\hline \hline After 6 days & & & \\
3.9 & $0.64 \pm 0.02$ & $0.01 \pm 0.03$ & $0.90 \pm 0.03$ \\
5.8 & $0.43 \pm 0.04$ & $0.13 \pm 0.04$ & $0.87 \pm 0.04$ \\
9.5 & $0.83 \pm 0.01$ & $0.28 \pm 0.20$ & $0.72 \pm 0.20$ \\
After 62 days & & & $0.96 \pm 0.01$ \\
4.4 & $0.67 \pm 0.02$ & $0.04 \pm 0.01$ & below level of detection \\
6.4 & $0.98 \pm 0.02$ & below level of detection \\
9.3 & $0.97 \pm 0.02$ & \multicolumn{2}{c}{} \\
\hline
\end{tabular}

Carbonate did not appear to have a significant influence on $\mathrm{Pu}(\mathrm{IV})$ sorption across the high $\mathrm{pH}$ region where $\mathrm{Pu}$-carbonate and $\mathrm{Pu}$-hydroxycarbonate species form. Sorption and hydrolysis of $\mathrm{Pu}(\mathrm{IV})$ appears to be more energetically favorable than formation of soluble carbonate species. This is expected based upon the relatively low carbonate concentrations used in these experiments and the propensity of $\mathrm{Pu}(\mathrm{IV})$ to sorb and/or hydrolyze. Conversely, in the $\mathrm{Pu}(\mathrm{V})$ samples, formation of $\mathrm{PuO}_{2}\left(\mathrm{CO}_{3}\right)_{\mathrm{x}}{ }^{1-2 \mathrm{x}}$ species clearly influenced sorption (Figure 3.6b). Between pH 4 and 8 (24 hour data), $\mathrm{CO}_{2}(\mathrm{~g})$-free and $\mathrm{CO}_{2}(\mathrm{~g})$-equilibrated samples behave nearly identically. However, at $\mathrm{pH}>8$, there is a sharp decrease in the $\mathrm{Pu}$ fraction sorbed in the $\mathrm{CO}_{2}(\mathrm{~g})$ equilibrated samples. This is consistent with the onset of $\mathrm{Pu}(\mathrm{V})$-carbonate formation $\left(\log \mathrm{K}^{\mathrm{o}}\right.$ $\mathrm{PuO}_{2} \mathrm{CO}_{3}{ }^{-}=5.1$, (Clark et al., 1995)). Between $\mathrm{pH} 9.5$ and 10, the effect of carbonate appears to plateau. This is likely due to the fixed carbonate concentration used over this $\mathrm{pH}$ range in these samples. The effect of carbonate is more substantial in the silica systems relative to the gibbsite systems. For example, at $\mathrm{pH} 9$ the $\mathrm{Pu}$ fraction sorbed was $78 \%$ and $44 \%$ for the gibbsite and silica systems, respectively. All other system parameters were the same. However, it is noteworthy that the effect of carbonate appears to be transient. At higher $\mathrm{pH}$ values, the aqueous phase $\mathrm{Pu}$ concentration after 62 days was significantly higher than after 24 hours. The data appear to more closely resemble the $\mathrm{CO}_{2}(\mathrm{~g})$-free system. The decreased sorption due to formation of aqueous $\mathrm{Pu}(\mathrm{V})$-carbonate species will not affect long term sorption behavior under these system conditions (longterm reduction to $\mathrm{Pu}(\mathrm{IV})$ ).

The $\mathrm{Pu}(\mathrm{V})$ samples appear to have undergone redox transformation over the course of the experiment. Similar to the gibbsite systems, the $\mathrm{Pu}$ fraction sorbed over time in neutral and acidic $\mathrm{pH}$ regions increased with time. The sorption of both $\mathrm{Pu}(\mathrm{IV})$ and $\mathrm{Pu}(\mathrm{V})$ samples after 24 hours and 62 days is shown in Figure 3.7. The data are dissimilar at 24 hours. However, after 62 days, the data appear to merge suggesting that a steady state has been reached. The shape and slope of the $\mathrm{Pu}(\mathrm{V})$ dataset underwent drastic changes to more closely resemble that of the $\mathrm{Pu}(\mathrm{IV})$ dataset. This provides circumstantial evidence of the surface mediated reduction of $\mathrm{Pu}(\mathrm{V})$ to $\mathrm{Pu}(\mathrm{IV})$. The equilibrium distribution of $\mathrm{Pu}$ in these silica suspensions appears to be defined as a steady state partitioning between aqueous $\mathrm{Pu}(\mathrm{V})$ and solid phase $\mathrm{Pu}(\mathrm{IV})$. Measurement of the aqueous $\mathrm{Pu}$ in $\mathrm{Pu}(\mathrm{IV})$ solutions in the acidic region indicate that the aqueous $\mathrm{Pu}$ was $\mathrm{Pu}(\mathrm{V})$. The oxidation state of aqueous $\mathrm{Pu}$ from the initially $\mathrm{Pu}(\mathrm{V})$ experiment was not performed. However, some filtration tests were performed and greater than $96 \%$ of the $\mathrm{Pu}$ was able to pass through a 3k MWCO centrifugal filter. This verified that $\mathrm{Pu}$ was not associated with a colloidal phase and likely a truly soluble species, most likely $\mathrm{Pu}(\mathrm{V})$. 


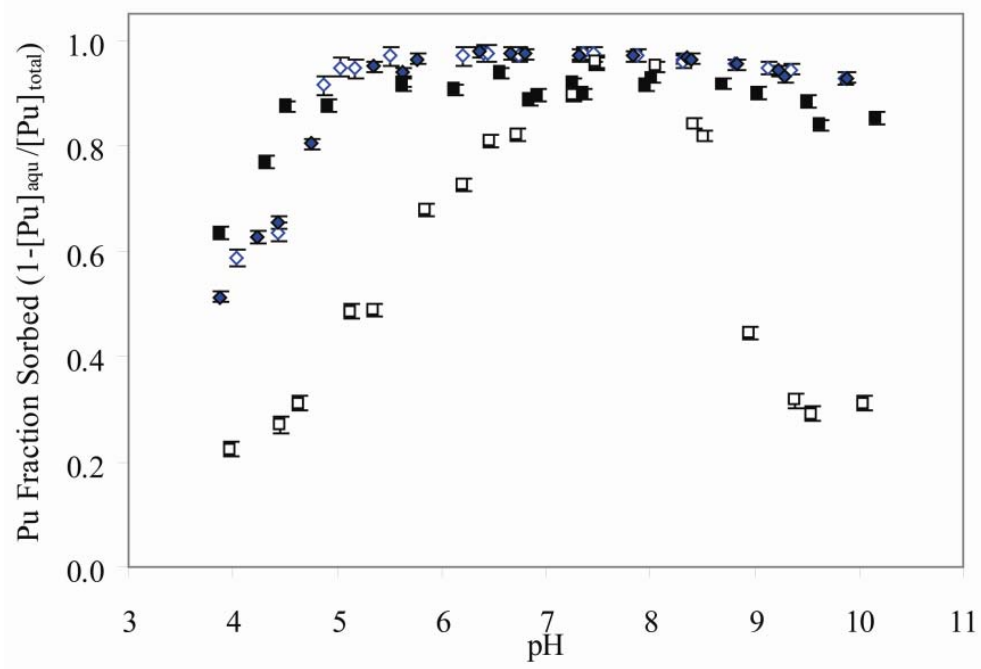

Figure 3.7: $\mathrm{Pu}(\mathrm{IV})$ (closed symbols) and $\mathrm{Pu}(\mathrm{V})$ (open symbols) sorption to silica after 24 hours (squares) and 62 days (diamonds) in $\mathrm{CO}_{2}(\mathrm{~g})$-equilibrated solutions.

It is interesting to note that sorption of $\mathrm{Pu}$ to silica is stronger at low $\mathrm{pH}$ values relative to gibbsite. A plot of the Pu distribution at equilibrium (62 days for silica and 300 days for gibbsite) is shown in Figure 3.8. While Pu strongly partitions to both minerals at high $\mathrm{pH}$, sorption of $\mathrm{Pu}$ to silica is stronger at low $\mathrm{pH}$. This is proposed to be due to low $\mathrm{pK}_{\mathrm{a}}$ of silanol surface sites (log $\mathrm{K} \cong 2$ ) which generate a net negative surface charge which may attract cationic Pu species in low $\mathrm{pH}$ suspensions.

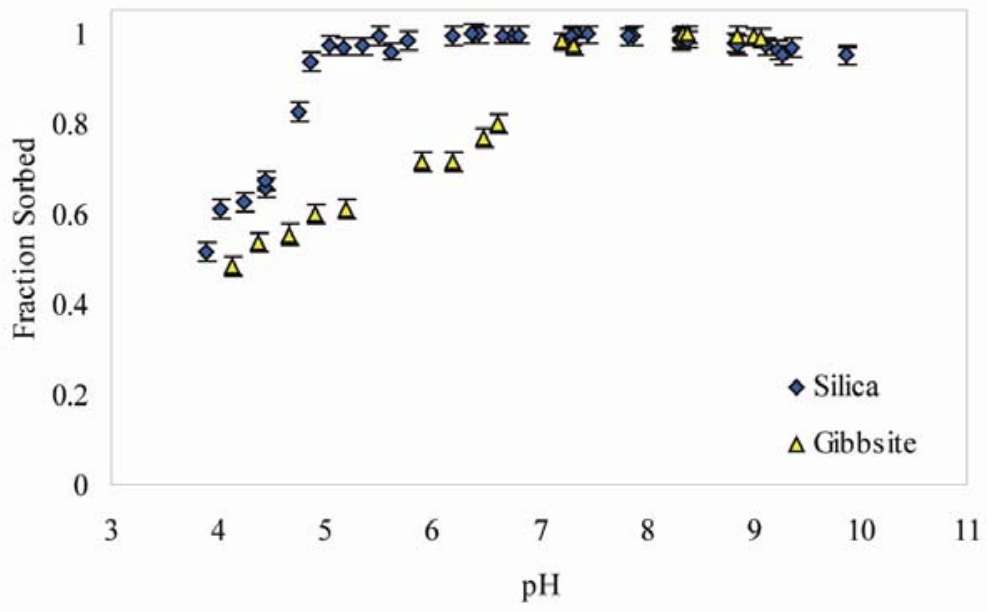

Figure 3.8: Pu sorption to silica (62 days) and gibbsite (300 days) in $\mathrm{CO}_{2}$ (g)-equilibrated solutions. 


\subsection{Pu(IV) and Pu(V) Sorption to Montmorillonite}

The results from $\mathrm{Pu}(\mathrm{IV})$ and $\mathrm{Pu}(\mathrm{V})$ sorption experiments in montmorillonite suspensions after 24 hours are shown in Figure 3.9. Pu(IV) strongly sorbed to montmorillonite within 24 hours at all $\mathrm{pH}$ values examined (Figure 3.9a). Additionally, there appears to be no effect of carbonate on $\mathrm{Pu}(\mathrm{IV})$ sorption as both $\mathrm{CO}_{2}(\mathrm{~g})$-equilibrated and $\mathrm{CO}_{2}(\mathrm{~g})$-free samples behave similarly. The partitioning of $\mathrm{Pu}(\mathrm{V})$ to montmorillonite after 24 hours was similar to that observed for silica and gibbsite systems (Figure 3.9b). Minimal sorption was observed up to $\mathrm{pH} 7$. Sorption in the $\mathrm{CO}_{2}(\mathrm{~g})$-free system increased between $\mathrm{pH} 7$ and 9 . $\mathrm{In}_{2}(\mathrm{~g})$-equilibrated suspensions, there was a lower $\mathrm{Pu}$ fraction sorbed between $\mathrm{pH} 8$ and 9 relative to the $\mathrm{CO}_{2}(\mathrm{~g})$ free system. Similar to silica and gibbsite systems discussed above, it appears formation of $\mathrm{PuO}_{2}\left(\mathrm{CO}_{3}\right)_{\mathrm{x}}{ }^{1-2 \mathrm{x}}$ carbonate species significantly decreases $\mathrm{Pu}(\mathrm{V})$ sorption above $\mathrm{pH} 8$.

At higher $\mathrm{pH}$ values (8 to 10$) \mathrm{Pu}(\mathrm{IV})$ sorption underwent a gradual decrease. There was a slight decrease in the $\mathrm{Pu}(\mathrm{V})$ fraction sorbed but this phenomena was considerably more pronounced in the $\mathrm{Pu}(\mathrm{IV})$ systems. The decrease in $\mathrm{Pu}$ sorption at high $\mathrm{pH}$ values is interesting in these systems as it was not observed for silica and gibbsite systems. Similar behavior was observed by Sanchez (1983) but the aqueous chemical species was not determined and no mechanism was proposed. The sorption appeared to achieve a steady state within 24 hours. Further sampling of the Pu(IV)montmorillonite suspensions after 21, 60, and 90 days showed little change in Pu sorption (Figure 3.10a).

After 160 days the concentration and oxidation state of aqueous $\mathrm{Pu}$ was measured. The aqueous $\mathrm{Pu}$ concentration was determined by measuring the Pu concentration in the supernatant of a centrifuged sample. For comparison, the Pu concentration was also measured in the filtrate obtained by passing $3 \mathrm{~mL}$ of the suspensions through a $3 \mathrm{k}$ MWCO centrifugal filter (Table 3.3). The results are comparable. The $3 \mathrm{k}$ MWCO filters have approximately a $4 \mathrm{~nm}$ pore size. Soderholm et al. (2008) found that concentrated Pu solutions form roughly $2 \mathrm{~nm}$ particles that may aggregate to greater than $20 \mathrm{~nm}$ particles. Recent work in our laboratory has shown that colloidal $\mathrm{Pu}(\mathrm{IV})$ sorbs to synthetic goethite crystals in approximately the same size range but is dominated by $2 \mathrm{~nm}$ colloids that aggregate to form $<20 \mathrm{~nm}$ particles. The size of the aggregate is no doubt a function of the initial concentration of $\mathrm{Pu}$ in solution. The oxidation state of $\mathrm{Pu}$ in the filtrate was measured using $\mathrm{LaF}_{3}$-coprecipitation and solvent extraction. The results (Table 3.3) indicate that $\mathrm{Pu}(\mathrm{V} / \mathrm{VI})$ was the predominant aqueous oxidation state. 

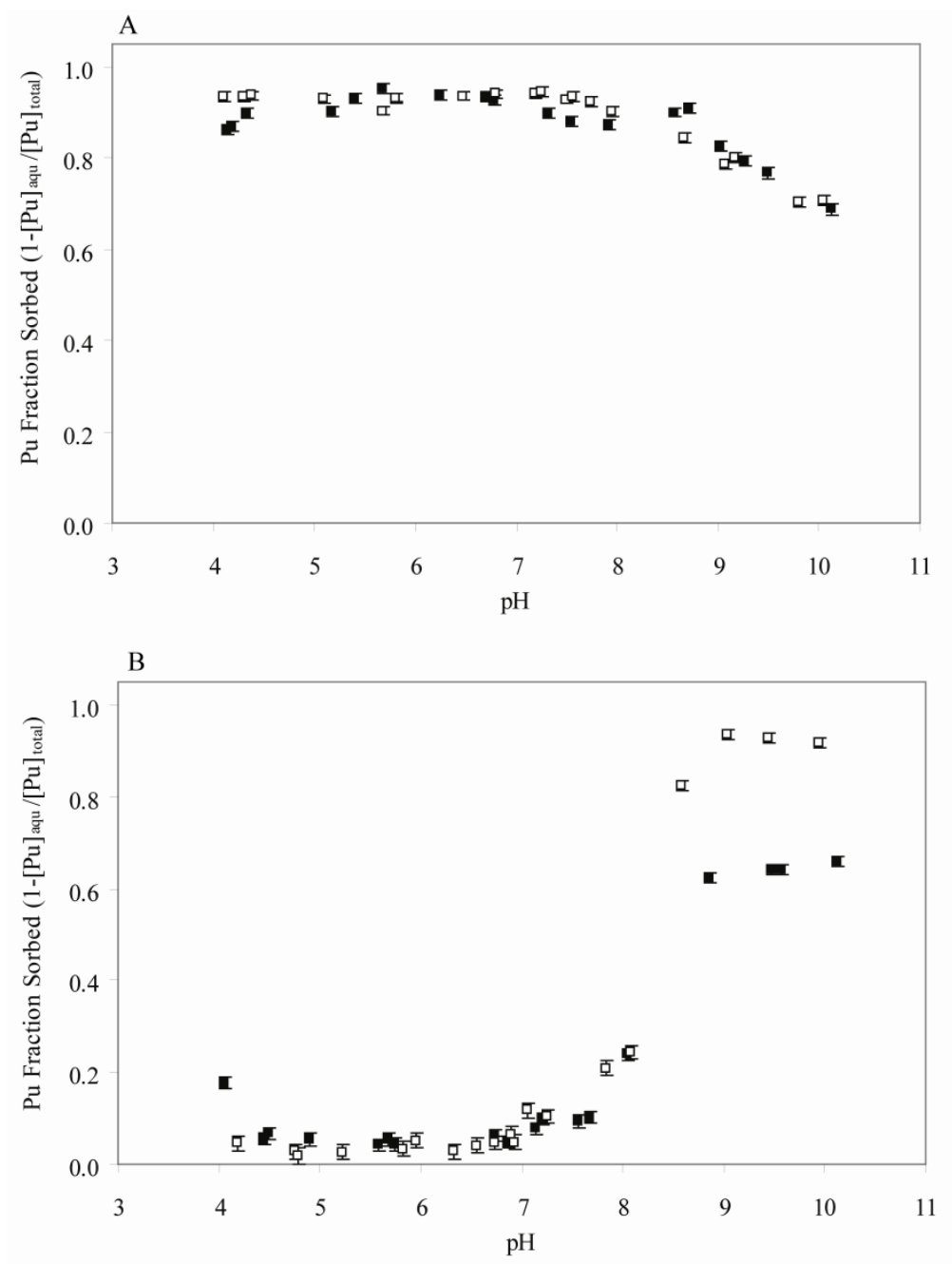

Figure 3.9: Sorption of (A) Pu(IV) and (B) Pu(V) to SWy-1 Na-montmorillonite at 24 hours. Open symbols represent systems where atmospheric $\mathrm{CO}_{2}(\mathrm{~g})$ was excluded.

Table 3.3: Fraction of Sorbed Pu and Oxidation State Analysis of Aqueous Pu in Montmorillonite Suspensions after 160 days. $\mathrm{Pu}(\mathrm{IV})$-montmorillonite experiment.

\begin{tabular}{cccccccc}
\hline & $\begin{array}{c}\text { Supernatant } \\
\text { Fraction } \\
\text { Sorbed }^{\mathrm{a}}\end{array}$ & $\begin{array}{c}\text { Filtrate } \\
\text { Fraction } \\
\text { Sorbed }^{\mathrm{b}}\end{array}$ & $\begin{array}{c}\text { Fraction } \\
\mathrm{Pu}(\mathrm{III} / \mathrm{IV})^{\mathrm{c}, \mathrm{e}}\end{array}$ & $\begin{array}{c}\text { Fraction } \\
\mathrm{Pu}(\mathrm{V} / \mathrm{VI})^{\mathrm{c}, \mathrm{e}}\end{array}$ & $\begin{array}{c}\text { Fraction } \\
\mathrm{Pu}(\mathrm{IV})^{\mathrm{d}, \mathrm{e}}\end{array}$ & $\begin{array}{c}\text { Fraction } \\
\mathrm{Pu}(\mathrm{V})^{\mathrm{d}, \mathrm{e}}\end{array}$ & $\begin{array}{c}\text { Fraction } \\
\mathrm{Pu}(\mathrm{VI})^{\mathrm{d}, \mathrm{e}}\end{array}$ \\
\hline \hline 7.95 & $0.92 \pm 0.05$ & $0.92 \pm 0.05$ & 0.09 & 0.91 & 0.02 & 0.91 & 0.07 \\
8.25 & $0.91 \pm 0.04$ & $0.91 \pm 0.04$ & 0.07 & 0.93 & 0.03 & 0.90 & 0.06 \\
8.31 & $0.93 \pm 0.05$ & $0.93 \pm 0.05$ & 0.06 & 0.94 & \multicolumn{2}{c}{ error $^{\text {in sample processing }}$} \\
9.12 & $0.79 \pm 0.03$ & $0.83 \pm 0.03$ & 0.12 & 0.88 & 0.22 & 0.69 & 0.09 \\
9.9 & $0.72 \pm 0.03$ & $0.78 \pm 0.03$ & 0.02 & 0.98 & 0.21 & 0.72 & 0.07 \\
\hline
\end{tabular}

${ }^{\mathrm{a}}$ Phases separated via centrifugation as done during sampling intervals

${ }^{b}$ Phases separated by passing suspension through $3 \mathrm{k}$ MWCO centrifugal filter of supernatant

${ }^{c}$ Using $\mathrm{LaF}_{3}$-coprecipitation technique

${ }^{\mathrm{d}}$ Using solvent extraction technique

${ }^{\mathrm{e}}$ Due to low concentration of $\mathrm{Pu}$ in all samples, minimum error of $10 \%$ should be assumed 
The surface-area-normalized sorption of $\mathrm{Pu}(\mathrm{IV})$ was greater in the montmorillonite suspension than might be expected based on an equivalent mixture of silica and gibbsite. The fraction of $\mathrm{Pu}$ sorbed after 24 hours in the montmorillonite, silica, and gibbsite suspensions around $\mathrm{pH} 4.5$ was $86 \%, 63 \%$, and $62 \%$, respectively. The surface area concentration in silica and gibbsite suspensions was $10 \mathrm{~m} \mathrm{~L}^{2} \mathrm{~L}^{-1}$ while the montmorillonite suspensions were $6.3 \mathrm{~m}^{2} \mathrm{~L}^{-1}$. Furthermore, since surface complexation is expected to only occur on the clay edge sites in the montmorillonite suspension, the effective surface area for surface complexation is likely considerably lower for montmorillonite. Apparently, partitioning of $\mathrm{Pu}(\mathrm{IV})$ in low $\mathrm{pH}$ montmorillonite is controlled by an additional mechanism not available to gibbsite and silica surfaces, such as ion exchange. Given the high effective charge of $\mathrm{Pu}(\mathrm{IV})$ and the exchange capacity of the Swy-1 montmorillonite (Appendix A) this appears to be a plausible explanation that will be discussed in greater detail below.

The $\mathrm{Pu}$ fraction sorbed in $\mathrm{Pu}(\mathrm{V})$ suspensions changed over the course of the experiment (Figure $3.10 \mathrm{~b})$. The system did not appear to reach a steady state after 90 days. With the exception of the samples at the highest $\mathrm{pH}$ values, the $\mathrm{Pu}$ fraction sorbed increased over time. In a similar set of experiments (Zavarin et al., 2008), the rate of $\mathrm{Pu}(\mathrm{V})$ sorption to montmorillonite at low $\mathrm{pH}$ values (3 to 6) was found to be significantly affected by $\mathrm{pH}$. $\mathrm{Pu}(\mathrm{V})$ sorption to montmorillonite was also found to be drastically affected by the background electrolyte concentration. The rate of $\mathrm{Pu}$ sorption was inversely related to the $\mathrm{NaCl}$ concentration and consistent with an ion exchange mechanism controlling Pu partitioning at low $\mathrm{pH}$. The slow sorption of $\mathrm{Pu}$ in the $\mathrm{Pu}(\mathrm{V})$ systems was proposed to be due to either cation or proton exchange of Pu coupled with surface mediated reduction of $\mathrm{Pu}(\mathrm{V})$ to $\mathrm{Pu}(\mathrm{IV})$. The "dip" in the fraction of Pu sorbed between $\mathrm{pH} 5$ and 7 (Figure $3.10 \mathrm{~b}$ ) is indicative of a transition point when ion exchange becomes negligible and surface complexation becomes the primary mechanism controlling Pu partitioning. This "dip" was also observed by Sanchez (1983) when examining Pu sorption to montmorillonite and Banik et al. (2007) when examining Pu sorption to kaolinite.

The $\mathrm{Pu}$ fraction sorbed in the $\mathrm{Pu}(\mathrm{V})$ systems after 90 days is slightly higher than that of the $\mathrm{Pu}(\mathrm{IV})$ systems. This is further circumstantial evience that formation of colloidal $\mathrm{Pu}(\mathrm{IV})$ may be controlling a small fraction of $\mathrm{Pu}$ in the $\mathrm{Pu}(\mathrm{IV})$ experiments. However, based upon the sorption behavior, solid free controls, and the measurement of $\mathrm{Pu}(\mathrm{V})$ within the initially $\mathrm{Pu}(\mathrm{IV})$ solutions, the fraction of colloidal $\mathrm{Pu}(\mathrm{IV})$ is expected to be less than $10 \%$. 

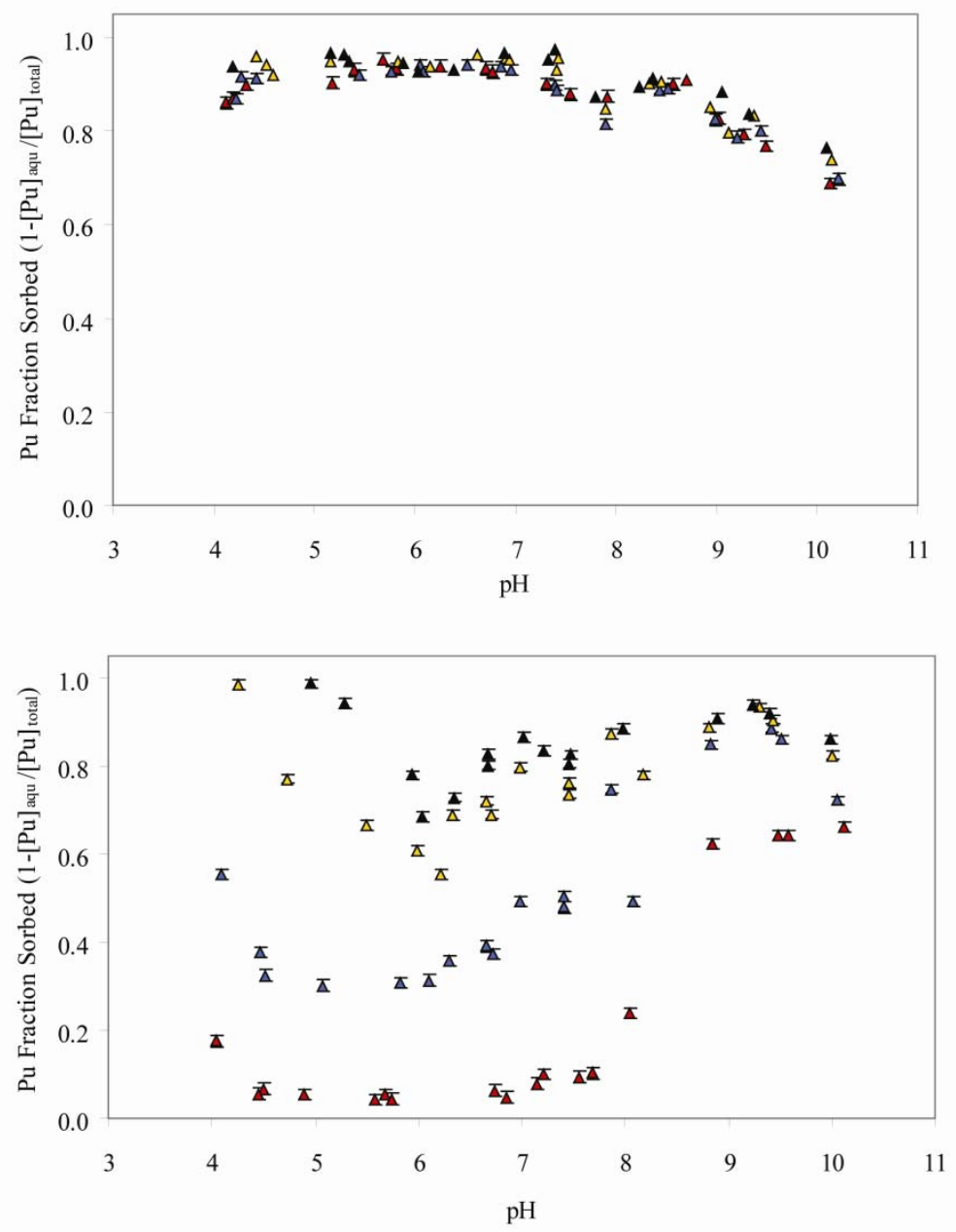

Figure 3.10: Sorption of (A) $\mathrm{Pu}(\mathrm{IV})$ and (B) $\mathrm{Pu}(\mathrm{V})$ to $\mathrm{SWy}-1$ Na-montmorillonite in carbonate equilibrated solutions at 24 hours (red), 21 days (blue), 60 days (orange), and 90 days (black).

\section{SURFACE COMPLEXATION MODELING USING EXISTING UGTA CONCEPTUAL MODEL}

\subsection{Description of Current UGTA Non-Electrostatic Surface Complexation Model}

A listing of the relevant aqueous species thermodynamic constants from the current UGTA thermochemical database is shown in Table 4.1. The ion sizes listed are used in the extended Debye-Huckel activity coefficent model (also known as the B-dot model). Modeling efforts in this work utilized the Davies equation with constants 0.509 and 0.30 , respectively. A value for the $\mathrm{Pu}(\mathrm{V}) / \mathrm{Pu}(\mathrm{IV})$ redox couple is reported in Table 4.1 but it has not been explicitly incorporated into current modeling efforts described in this chapter in order to remain consistent with the current UGTA database. Efforts have been made in Chapter 5 to fix a redox potential of the system and allow the $\mathrm{Pu}(\mathrm{IV} / \mathrm{V})$ couple to come to equilibrium. 
Table 4.1 Summary of Aqueous Complex Thermodynamic Constants in Current UGTA Database*

\begin{tabular}{|c|c|c|c|}
\hline Species & Reaction & $\begin{array}{c}\text { Ion Size } \\
(\mathrm{A})^{* *}\end{array}$ & $\begin{array}{l}\log \mathrm{K} \\
\left(25^{\circ} \mathrm{C}\right)\end{array}$ \\
\hline \multicolumn{4}{|l|}{ Complexation } \\
\hline$\overline{\mathrm{OH}^{-}}$ & $\mathrm{H}_{2} \mathrm{O} \leftrightarrow \mathrm{OH}^{-}+\mathrm{H}^{+}$ & 3.5 & -14 \\
\hline $\mathrm{CO}_{2}(\mathrm{aq})$ & $\mathrm{H}++\mathrm{HCO}_{3}^{-} \leftrightarrow \mathrm{CO}_{2}(\mathrm{aq})$ & 3 & 6.34 \\
\hline $\mathrm{CO}_{3}^{--}$ & $\mathrm{HCO}_{3}^{-} \leftrightarrow \mathrm{H}++\mathrm{CO}_{3}^{--}$ & 4.5 & -10.33 \\
\hline$\overline{\mathrm{NaCl}(\mathrm{aq})}$ & $\mathrm{Na}++\mathrm{Cl}^{-} \leftrightarrow \mathrm{NaCl}(\mathrm{aq})$ & 3 & -0.777 \\
\hline $\mathrm{NaCO}_{3}^{-}$ & $\mathrm{Na}++\mathrm{HCO}_{3}^{-} \leftrightarrow \mathrm{H}^{+}+\mathrm{NaCO}_{3}^{-}$ & 4 & -9.814 \\
\hline $\mathrm{NaHCO}_{3}(\mathrm{aq})$ & $\mathrm{Na}++\mathrm{HCO}_{3}^{-} \leftrightarrow \mathrm{NaCO}_{3}^{-}$ & 3 & 0.154 \\
\hline $\mathrm{NaOH}(\mathrm{aq})$ & $\mathrm{Na}++\mathrm{H}_{2} \mathrm{O} \leftrightarrow \mathrm{NaOH}(\mathrm{aq})+\mathrm{H}^{+}$ & 3 & -14.205 \\
\hline $\mathrm{PuOH}^{+++}$ & $\mathrm{Pu}^{4+}+\mathrm{H}_{2} \mathrm{O} \leftrightarrow \mathrm{PuOH}^{+++}+\mathrm{H}^{+}$ & 5 & -0.78 \\
\hline $\mathrm{Pu}(\mathrm{OH})_{2}{ }^{++}$ & $\mathrm{Pu}^{4+}+2 \mathrm{H}_{2} \mathrm{O} \leftrightarrow \mathrm{Pu}(\mathrm{OH})_{2}^{++}+2 \mathrm{H}^{+}$ & 4.5 & -1.66 \\
\hline $\mathrm{Pu}(\mathrm{OH})_{3}^{+}$ & $\mathrm{Pu}^{4+}+3 \mathrm{H}_{2} \mathrm{O} \leftrightarrow \mathrm{Pu}(\mathrm{OH})_{3}^{+}+3 \mathrm{H}^{+}$ & 4 & -4.62 \\
\hline $\mathrm{Pu}(\mathrm{OH})_{4}(\mathrm{aq})$ & $\mathrm{Pu}^{4+}+4 \mathrm{H}_{2} \mathrm{O} \leftrightarrow \mathrm{Pu}(\mathrm{OH})_{4}(\mathrm{aq})+4 \mathrm{H}^{+}$ & 3 & -8.85 \\
\hline $\mathrm{Pu}(\mathrm{OH})_{2}\left(\mathrm{CO}_{3}\right)_{2}^{--}$ & $\mathrm{Pu}^{4+}+2 \mathrm{H}_{2} \mathrm{O}+2 \mathrm{HCO}_{3}^{-} \leftrightarrow \mathrm{Pu}(\mathrm{OH})_{2}\left(\mathrm{CO}_{3}\right)^{2--}+4 \mathrm{H}^{+}$ & 4 & -2.75 \\
\hline $\mathrm{Pu}(\mathrm{OH})_{4}\left(\mathrm{CO}_{3}\right)_{2}$ & $\mathrm{Pu}^{4+}+4 \mathrm{H}_{2} \mathrm{O}+2 \mathrm{HCO}_{3}^{-} \leftrightarrow \mathrm{Pu}(\mathrm{OH})_{4}\left(\mathrm{CO}_{3}\right)^{2--}+6 \mathrm{H}^{+}$ & 5 & -25.53 \\
\hline $\mathrm{Pu}\left(\mathrm{CO}_{3}\right)_{4}^{---}$ & $\mathrm{Pu}^{4+}+4 \mathrm{HCO}_{3}^{-} \leftrightarrow \mathrm{Pu}\left(\mathrm{CO}_{3}\right)_{4}^{4-}+4 \mathrm{H}^{+}$ & 5 & -4.62 \\
\hline $\mathrm{Pu}\left(\mathrm{CO}_{3}\right)_{5}^{6-}$ & $\mathrm{Pu}^{4+}+5 \mathrm{HCO}_{3}^{-} \leftrightarrow \mathrm{Pu}\left(\mathrm{CO}_{3}\right)_{5}^{6-}+5 \mathrm{H}^{+}$ & 5 & -16.3 \\
\hline $\mathrm{PuO}_{2} \mathrm{OH}(\mathrm{aq})$ & $\mathrm{PuO}_{2}^{+}+\mathrm{H}_{2} \mathrm{O} \leftrightarrow \mathrm{PuO}_{2} \mathrm{OH}(\mathrm{aq})+\mathrm{H}^{+}$ & 3 & -9.7 \\
\hline $\mathrm{PuO}_{2} \mathrm{CO}_{3}^{-}$ & $\mathrm{PuO}_{2}^{+}+\mathrm{HCO}_{3}^{-} \leftrightarrow \mathrm{PuO}_{2} \mathrm{CO}_{3}^{-}+\mathrm{H}^{+}$ & 4 & -5.21 \\
\hline $\mathrm{PuO}_{2}\left(\mathrm{CO}_{3}\right)_{2}^{---}$ & $\mathrm{PuO}_{2}^{+}+2 \mathrm{HCO}_{3}^{-} \leftrightarrow \mathrm{PuO}_{2}\left(\mathrm{CO}_{3}\right)_{2}^{3-}+2 \mathrm{H}^{+}$ & 4 & -14.12 \\
\hline $\mathrm{PuO}_{2}\left(\mathrm{CO}_{3}\right)_{3}{ }^{5-}$ & $\mathrm{PuO}_{2}^{+}+3 \mathrm{HCO}_{3}^{-} \leftrightarrow \mathrm{PuO}_{2}\left(\mathrm{CO}_{3}\right)_{3}{ }^{5-}+3 \mathrm{H}^{+}$ & 5 & -26 \\
\hline \multicolumn{4}{|l|}{ Redox } \\
\hline $\mathrm{PuO}_{2}^{+} / \mathrm{Pu}^{+++}$ & $\mathrm{Pu}^{++++}+0.25 \mathrm{O}_{2}(\mathrm{~g})+1.5 \mathrm{H}_{2} \mathrm{O} \leftrightarrow \mathrm{PuO}_{2}^{+}+3 \mathrm{H}^{+}$ & 4 & 3.439 \\
\hline
\end{tabular}

*Constants predominantly taken from DATACOM.V8.R6 of the GEMBOCHS thermodynamic database (Turner et al., 1998) and associated revisions (Carle et al., 2006; Pawloski et al., 2000;

Pawloski et al., 2001; Tompson et al., 1999).

A summary of the relevant Non-electrostatic Surface Complexation Constants in the current UGTA database is listed in Table 4.2. We initially present predicted Pu sorption to silica, gibbsite, and montmorillonite using the current UGTA database (Tables 4.1 and 4.2). The data are later re-fit and non-electrostatic surface complexation constants updated.

Mineral characteristics used in surface complexation modeling are presented in Table 4.3. The site density of 2.3 sites per $\mathrm{nm}^{2}$ used for gibbsite and silica is the recommended value for all minerals suggested by Davis and Kent (1990). It is assumed that the edge sites of montmorillonite are the locations for reactive surface sites. These sites represent $10 \%$ of the total available surface area (Turner et al., 1998). Therefore, the site density was decreased to 0.23 sites per $\mathrm{nm}^{2}$ when calculating the aluminol and silanol site concentrations. White and Zelazny (1988) proposed an Al:Si ratio of 0.83 for the edge sites on montrmorillonite. This ratio was used to adjust the surface site distribution as shown in Table 4.3. 
Table 4.2: Summary of non-electrostatic surface complexation constants from current UGTA database

\begin{tabular}{|c|c|c|}
\hline Species & Reaction & $\begin{array}{l}\text { Current UGTA Database, } \\
\log \mathrm{K}^{*}\end{array}$ \\
\hline $\mathrm{AlO}^{-}$ & $\mathrm{AlOH} \leftrightarrow \mathrm{AlO}^{-}+\mathrm{H}^{+}$ & -9.73 \\
\hline $\mathrm{AlOH}_{2}^{+}$ & $\mathrm{AlOH}+\mathrm{H}^{+} \leftrightarrow \mathrm{AlOH}_{2}^{+}$ & 8.33 \\
\hline $\mathrm{AlOPu}(\mathrm{OH})_{2}{ }^{+}$ & $\mathrm{AlOH}+\mathrm{Pu}^{4+}+2 \mathrm{H}_{2} \mathrm{O} \leftrightarrow \mathrm{AlOPu}(\mathrm{OH})_{2}^{+}+3 \mathrm{H}^{+}$ & 5.95 \\
\hline $\mathrm{AlOPu}(\mathrm{OH})_{4}^{-}$ & $\mathrm{AlOH}+\mathrm{Pu}^{4+}+4 \mathrm{H}_{2} \mathrm{O} \leftrightarrow \mathrm{AlOPu}(\mathrm{OH})_{4}^{-}+5 \mathrm{H}^{+}$ & -11.93 \\
\hline $\mathrm{AlOPuO}_{2}{ }^{\circ}$ & $\mathrm{AlOH}+\mathrm{PuO}_{2}^{+} \leftrightarrow \mathrm{AlOPuO}_{2}{ }^{\circ}+\mathrm{H}+$ & -3.09 \\
\hline $\mathrm{SiO}^{-}$ & $\mathrm{SiOH} \leftrightarrow \mathrm{SiO}^{-}+\mathrm{H}^{+}$ & -7.2 \\
\hline $\mathrm{SiOPu}(\mathrm{OH})_{2}^{+}$ & $\mathrm{SiOH}+\mathrm{Pu}^{4+}+2 \mathrm{H}_{2} \mathrm{O} \leftrightarrow \mathrm{SiOPu}(\mathrm{OH})_{2}^{+}+3 \mathrm{H}^{+}$ & 2.32 \\
\hline $\mathrm{SiOPuO}_{2}{ }^{\mathrm{O}}$ & $\mathrm{SiOH}+\mathrm{PuO}_{2}^{+} \leftrightarrow \mathrm{SiOPuO}_{2}^{\circ}+\mathrm{H}^{+}$ & -6.43 \\
\hline $\mathrm{SiOPuO}_{2} \mathrm{OH}^{-}$ & $\mathrm{SiOH}+\mathrm{H}_{2} \mathrm{O}+\mathrm{PuO}_{2}^{+} \leftrightarrow \mathrm{SiOPuO}_{2} \mathrm{OH}^{-}+2 \mathrm{H}^{+}$ & -14.8 \\
\hline
\end{tabular}

Table 4.3: Mineral characteristics used in surface complexation modeling

\begin{tabular}{ccccc}
\hline Mineral & $\begin{array}{c}\text { Surface Area } \\
\left(\mathrm{m}^{2} \mathrm{~g}^{-1}\right)\end{array}$ & Site Density & Site Type & $\begin{array}{c}\text { Estimated Site Concentration in } 10 \\
\mathrm{~m}^{2} \mathrm{~L}^{-1} \text { Suspension }\left(\mathrm{mol} \mathrm{L}^{-1}\right)\end{array}$ \\
\hline Silica & 1.18 & 2.3 & $>\mathrm{SiOH}$ & $3.85 \mathrm{E}-5$ \\
\hline Gibbsite & 1.85 & 2.3 & $>\mathrm{AlOH}$ & $3.85 \mathrm{E}-5$ \\
\hline Montmorillonite & 27.17 & 0.23 & $\begin{array}{c}>\mathrm{SiOH}(0.45)^{*} \\
>\mathrm{AlOH}(0.55)^{*}\end{array}$ & $\begin{array}{c}\text { > SiOH, 9.64E-7 } \\
\text { Total, } 1.76 \mathrm{E}-6\end{array}$ \\
\hline
\end{tabular}

*Fraction of Total Sites based upon assumed Al:Si ratio of 0.83 (White and Zelazny, 1988)

\subsection{Prediction of Pu Sorption Using Current UGTA Database}

\subsubsection{Prediction of Pu Sorption to Gibbsite}

Using the current UGTA database (Tables 4.1 and 4.2) along with the mineral characteristics (Table 4.3), $\mathrm{Pu}(\mathrm{IV})$ and $\mathrm{Pu}(\mathrm{V})$ sorption to gibbsite was predicted and compared with sorption data. The 24 hour data was used to minimize effects of $\mathrm{Pu}(\mathrm{IV})$ oxidation and $\mathrm{Pu}(\mathrm{V})$ reduction in sorption data. The model output is shown in Figure 4.1. A table listing the concentrations for all species in each system that used to generate the model input files is reported in Appendix C.

Sorption of $\mathrm{Pu}(\mathrm{IV})$ was over-predicted at low $\mathrm{pH}$ values and provided a reasonable fit to the data at high $\mathrm{pH}$ values. As discussed earlier, the low $\mathrm{Pu}$ sorption at low $\mathrm{pH}$ may be the result of $\mathrm{Pu}(\mathrm{IV})$ oxidation by dissolved oxygen. Since $\mathrm{Pu}(\mathrm{V})$ was not considered in this model, this is considered a modeling artifact. The $\mathrm{Pu}(\mathrm{IV})-\mathrm{AlOH}$ constants listed in Table 4.2 were calculated by Zavarin and Bruton (2004) based upon the data of Righetto et al. (1991) and Allard et al. (1982). Neither of the earlier studies measured or attempted to control the oxidation state of $\mathrm{Pu}$ used in their experiments. Therefore, Zavarin and Bruton (2004) were required to deduce the Pu oxidation state based upon sorption behavior. In this manner, constants for both $\mathrm{Pu}(\mathrm{IV})$ and $\mathrm{Pu}(\mathrm{V})$ were calculated from the data reported by Righetto et al. (1991) and constants for $\mathrm{Pu}(\mathrm{IV})$ were calculated based on the data of Allard et al. (1982). 
Sorption of $\mathrm{Pu}(\mathrm{V})$ was accurately predicted for the $\mathrm{CO}_{2}(\mathrm{~g})$-free system (Figure 4.1c). The good agreement supports the assumption of Zavarin and Bruton (Zavarin and Bruton, 2004) that $\mathrm{Pu}(\mathrm{V})$ was present in the experiments performed by Righetto et al. (1991). Prediction of $\mathrm{Pu}(\mathrm{V})$ sorption in the presence of carbonate was under-predicted. This may be due to uncertainty in the thermodynamic constants for $\mathrm{Pu}(\mathrm{V})$-carbonates or due to an underprediction of the stability of the $\mathrm{AlOPuO}_{2}{ }^{\mathrm{O}}$ surface complex.

\subsubsection{Prediction of Pu Sorption to Silica}

Predictions of $\mathrm{Pu}(\mathrm{IV})$ and $\mathrm{Pu}(\mathrm{V})$ sorption to silica using the current UGTA database are shown in Figure 4.2. The constants within the current database cannot accurately predict $\mathrm{Pu}$ sorption to silica. Sorption of $\mathrm{Pu}(\mathrm{IV})$ is simulated using only one surface species, $\mathrm{SiOPu}(\mathrm{OH})_{2}{ }^{+}$. This species is predicted to sorb significantly at low $\mathrm{pH}$. However, no additional $\mathrm{Pu}(\mathrm{IV})-\mathrm{SiOH}$ species are included in the model so no sorption of $\mathrm{Pu}(\mathrm{IV})$ is predicted at high $\mathrm{pH}$. The poor $\mathrm{SiOH}-\mathrm{Pu}(\mathrm{IV})$ predition is primarily due to insufficient data available for $\mathrm{Pu}(\mathrm{IV})$-silica system. Zavarin and Bruton (2004) estimated the $\mathrm{SiOPu}(\mathrm{OH})_{2}{ }^{+}$constant from data describing $\mathrm{Pu}(\mathrm{IV})$ sorption to montmorillonite. In that model fit, $\mathrm{Pu}(\mathrm{IV})-\mathrm{AlOH}$ species were assumed to predominate in the high $\mathrm{pH}$ region. Therefore, there was little need for additional $\mathrm{Pu}(\mathrm{IV})-\mathrm{SiOH}$ species in the model.

Constants for the two $\mathrm{Pu}(\mathrm{V})-\mathrm{SiOH}$ species included in the current database were fitted to data collected in a single sorption experiment (Sanchez, 1983). Sanchez (1983) examined $\mathrm{Pu}(\mathrm{V})$ sorption to silica gel and observed minimal sorption even up to $\mathrm{pH} 9$ in a solution with a total $\mathrm{Pu}$ concentration of $10^{-14} \mathrm{M}$. The weak sorption coupled with a low total Pu concentration and very high silica gel surface areas resulted in relatively low fitted constants for the $\mathrm{SiOPuO}_{2}{ }^{\circ}$ and $\mathrm{SiOPuO}{ }_{2} \mathrm{OH}^{-}$species.

\subsubsection{Prediction of Pu Sorption to Montmorillonite}

Prediction of $\mathrm{Pu}(\mathrm{IV})$ sorption to montmorillonite provides acceptable fits to the data but several of the subtle effects of $\mathrm{pH}$ are not accurately predicted (Figure 4.3). The model incorrectly predicts a decrease in sorption at low $\mathrm{pH}$. Additionally, the model does not predict the decrease in sorption observed at high $\mathrm{pH}$. As discussed in Chapter 3, the aqueous $\mathrm{Pu}$ at high $\mathrm{pH}$ regions was likely a mixture of $\mathrm{Pu}(\mathrm{V})$ and colloidal $\mathrm{Pu}(\mathrm{IV})$. Since the model does not consider formation of either of these species, it would not be expected to provide a good fit to the data.

Due to the low constants for $\mathrm{Pu}(\mathrm{V})-\mathrm{SiOH}$ species, sorption of $\mathrm{Pu}(\mathrm{V})$ to montmorillonte at low $\mathrm{pH}$ is drastically underpredicted (Figure 4.3). As the $\mathrm{pH}$ of the system increases, sorption of $\mathrm{Pu}(\mathrm{V})$ to aluminol sites increases and the model fit improves. However, an acceptable prediction of the $\mathrm{Pu}(\mathrm{V})$-montmorillonite sorption data was not possible with the constants available in the current database. 

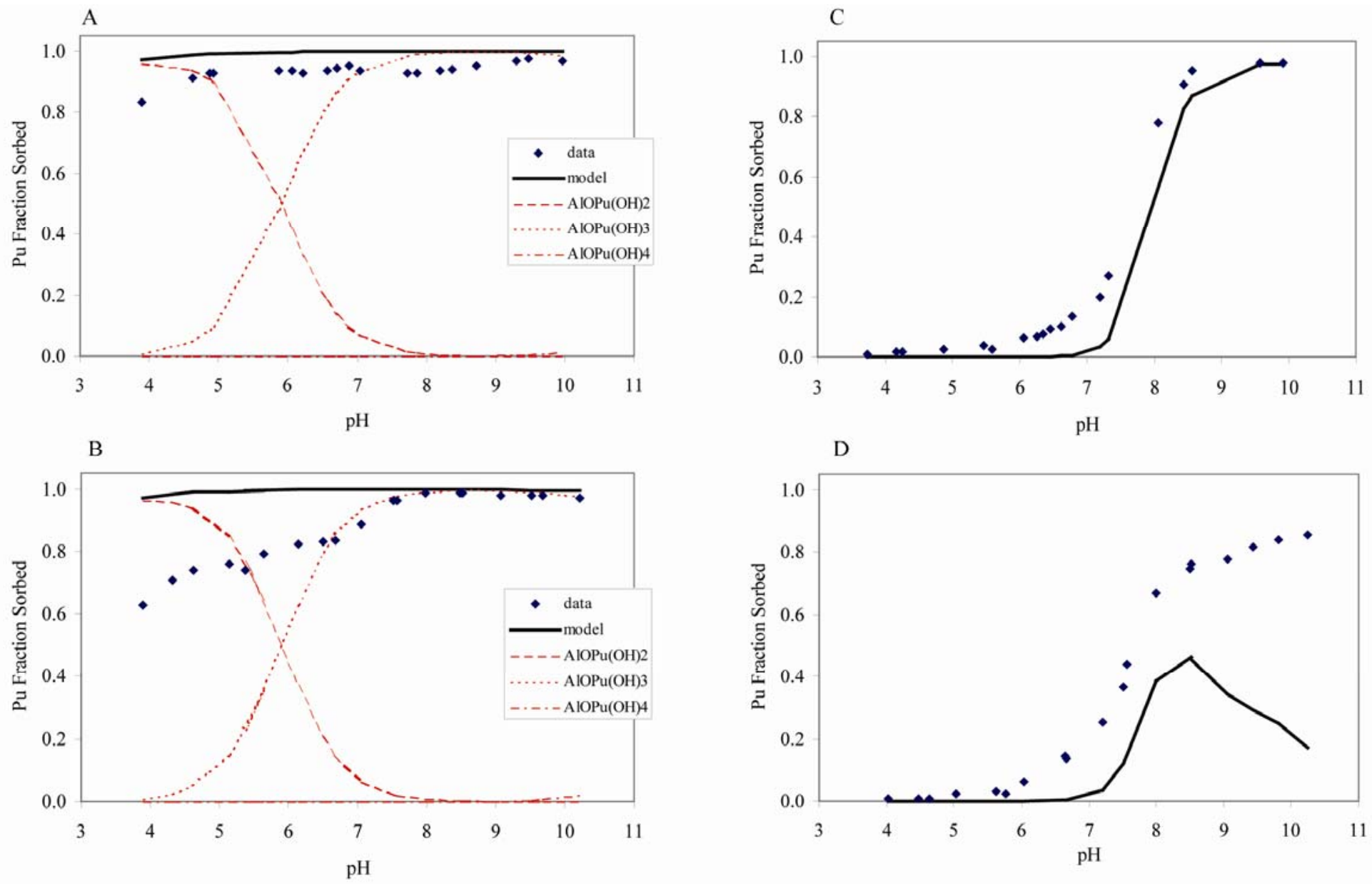

Figure 4.1: Prediction of Pu sorption to gibbsite after 24 hours using non-electrostatic surface complexation constants defined in the current UGTA database for (A) initially $\mathrm{Pu}(\mathrm{IV})-\mathrm{CO}_{2}(\mathrm{~g})$ free, (B) initially $\mathrm{Pu}(\mathrm{IV}), \mathrm{CO}_{2}(\mathrm{~g})$-equilibrated, $(\mathrm{C})$ initially $\mathrm{Pu}(\mathrm{V}), \mathrm{CO}_{2}(\mathrm{~g})$-free, and (D) initially $\mathrm{Pu}(\mathrm{V}), \mathrm{CO}_{2}(\mathrm{~g})$-equilibrated sorption data. Speciation in $\mathrm{Pu}(\mathrm{V})$ systems is not displayed as $\mathrm{AlOPuO}_{2}{ }^{0}$ is the only surface complex defined in the current UGTA model. 

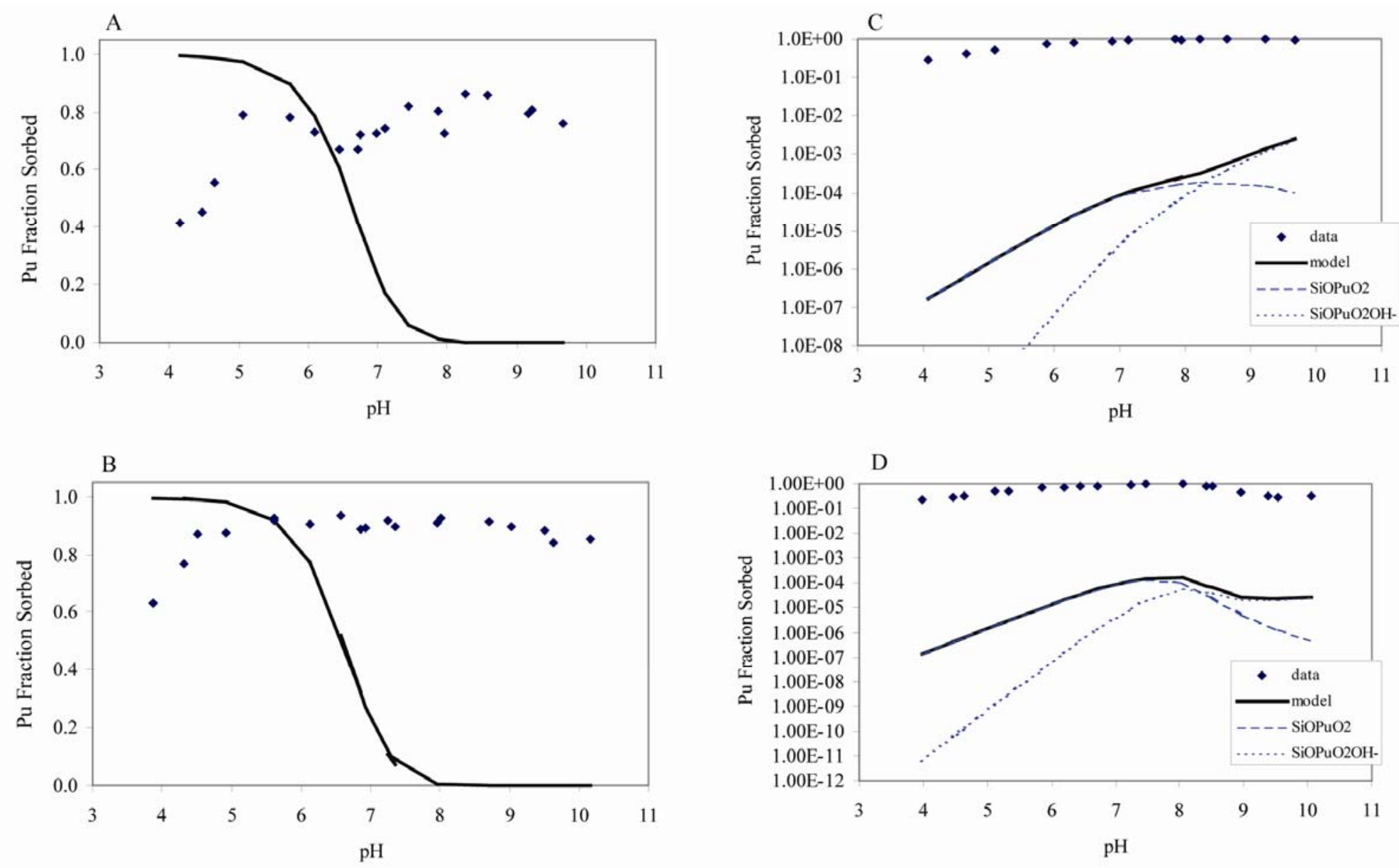

Figure 4.2: Prediction of Pu sorption to silica after 24 hours using non-electrostatic surface complexation constants defined in the current UGTA database for (A) initially $\mathrm{Pu}(\mathrm{IV})-\mathrm{CO}_{2}(\mathrm{~g})$ free, (B) initially $\mathrm{Pu}(\mathrm{IV}), \mathrm{CO}_{2}(\mathrm{~g})$-equilibrated (C) initially $\mathrm{Pu}(\mathrm{V}), \mathrm{CO}_{2}(\mathrm{~g})$-free, and (D) initially $\mathrm{Pu}(\mathrm{V}), \mathrm{CO}_{2}(\mathrm{~g})$-equilibrated sorption data. Speciation in $\mathrm{Pu}(\mathrm{IV})$ systems is not displayed as only one surface complex is defined in the current UGTA model. 

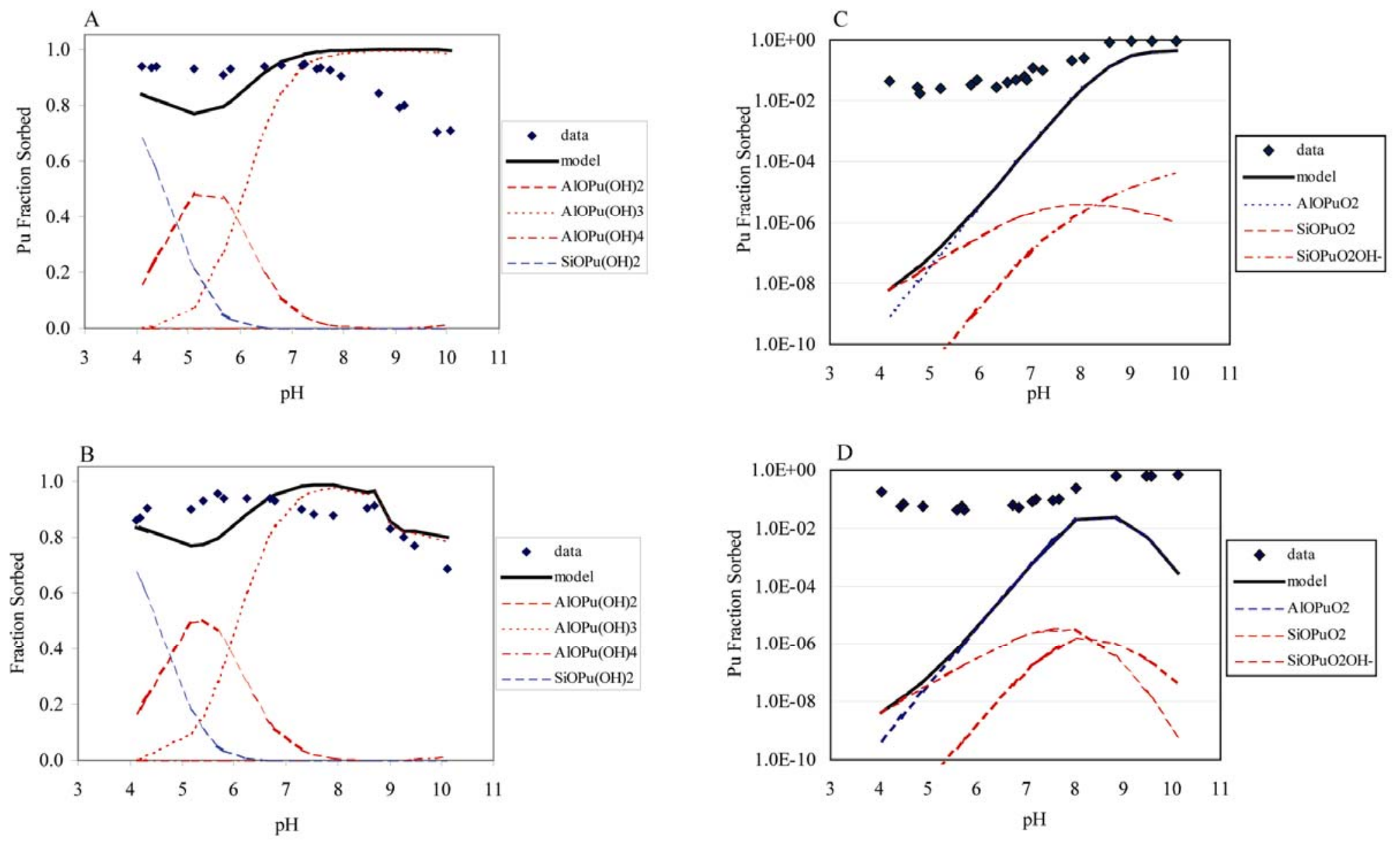

Figure 4.3: Prediction of Pu sorption to montmorillonite after 24 hours using non-electrostatic surface complexation constants defined in the current UGTA database for (A) initially $\mathrm{Pu}(\mathrm{IV})-\mathrm{CO}_{2}(\mathrm{~g})$ free (B) initially $\mathrm{Pu}(\mathrm{IV}), \mathrm{CO}_{2}(\mathrm{~g})$-equilibrated (C) initially $\mathrm{Pu}(\mathrm{V}), \mathrm{CO}_{2}(\mathrm{~g})$-free, and (D) initially $\mathrm{Pu}(\mathrm{V}), \mathrm{CO}_{2}(\mathrm{~g})$ equilibrated sorption data. 


\subsection{Determination of Revised Sorption Constants}

$\mathrm{Pu}(\mathrm{IV})$ and $\mathrm{Pu}(\mathrm{V})$ sorption to silica and gibbsite were fit to obtain new non-electrostatic SCM constants for use in a revised UGTA database. To remain compatible with the current database, the aqueous thermodynamic constants listed in Table 4.1 and the protonation/deprotonation constants for aluminol and silanol groups (Table 4.2) were used. Changing these constants would require refitting of the entire database prior to incorporation of the revised $\mathrm{Pu}$ constants.

When modeling $\mathrm{Pu}(\mathrm{V})$ systems, only the data from $\mathrm{CO}_{2}(\mathrm{~g})$-free systems was used to generate sorption constants. Those constants were used to simulate the $\mathrm{CO}_{2}(\mathrm{~g})$-equilibrated system without additional fitting as a test of the reliability of the constants. Unfortunately, due to the observed instability of aqueous $\mathrm{Pu}(\mathrm{IV})$, we were not able to implement this approach when modeling $\mathrm{Pu}(\mathrm{IV})$ sorption data. Sorption constants were determined from each dataset and compared to determine the most "reliable" constant. It is important to note that similar considerations should be made for the $\mathrm{Pu}(\mathrm{V})$ dataset due to surface mediated reduction to $\mathrm{Pu}(\mathrm{IV})$. However, reduction of $\mathrm{Pu}(\mathrm{V})$ on non-redox active surfaces such as the gibbsite and silica used here is expected to be relatively slow, as demonstrated by the slow shift in the sorption edge in $\mathrm{Pu}(\mathrm{V})$ sorption experiments (Figures 3.5 and 3.10). Modeling of $\mathrm{Pu}(\mathrm{V})$ constants was only performed using sorption data obtained after 24 hours where the fraction of $\mathrm{Pu}(\mathrm{IV})$ on the surface would be minimal. This may not be a valid assumption. However, the alternative is to couple $\mathrm{Pu}(\mathrm{V} / \mathrm{IV})$ in the sorption model which is beyond the scope of the modeling effort presented in this chapter. (Note: Such a modeling effort will require reconsideration of the conceptual framework of Pu sorption in the current UGTA database. Such a revised model is proposed in Chapter 5.) A list of the constants determined from each dataset is shown in Table 4.4. Model fits for each dataset and relevant discussion are presented below.

\subsection{1 $\mathrm{Pu}(\mathrm{IV})$ Sorption to Gibbsite}

Three separate model fits to Pu(IV)-gibbsite sorption data are shown in Figure 4.4. As discussed in Chapter 3, there was an observed difference between the sorption of $\mathrm{Pu}(\mathrm{IV})$ after 24 hours in $\mathrm{CO}_{2}(\mathrm{~g})$-free and $\mathrm{CO}_{2}(\mathrm{~g})$-equilibrated systems at low $\mathrm{pH}$ values. The constants obtained from fits to each dataset are shown in Table 4.4. In all systems the dominant surface species at low $\mathrm{pH}$ was $\mathrm{AlOPu}(\mathrm{OH})_{2}{ }^{+}$. In accordance with the observed sorption behavior at low $\mathrm{pH}$ values the log $\mathrm{K}$ for $\mathrm{AlOPu}(\mathrm{OH})_{2}{ }^{+}$was 5.1 for the $\mathrm{CO}_{2}(\mathrm{~g})$-free system and 4.55 for the $\mathrm{CO}_{2}(\mathrm{~g})$-equilibrated system. The $\log \mathrm{K}$ fitted for the 62 day sorption data further decreased to 4.1 due to the net desorption of Pu observed. The $\log \mathrm{K}$ of 5.1 obtained for the $\mathrm{CO}_{2}(\mathrm{~g})$-free 24 hour sorption dataset compared most favorably with the value of 5.95 in the current UGTA database. Since it was shown that the aqueous $\mathrm{Pu}$ in the $\mathrm{CO}_{2}(\mathrm{~g})$-equilibrated datasets was predominantly $\mathrm{Pu}(\mathrm{V})$, the $\log \mathrm{K}$ values for $\mathrm{Pu}(\mathrm{IV})$ sorption constants in that range will be artificially low. Therefore, the $\log \mathrm{K}$ value of 5.1 for the $\mathrm{AlOPu}(\mathrm{OH})_{2}{ }^{+}$species is recommended as a lower limit.

The $\log \mathrm{K}$ values for the neutrally charged $\mathrm{AlOPu}(\mathrm{OH})_{3}{ }^{\mathrm{o}}$ species were -3.37 and -3.52 for the 24 hours datasets in $\mathrm{CO}_{2}(\mathrm{~g})$-free and $\mathrm{CO}_{2}(\mathrm{~g})$-equilibrated systems, respectively. There is no corresponding neutrally charged species considered in the current UGTA database. 
Table 4.4: Summary of Surface Complexation Constants Determined for Pu-silica and Pu-gibbsite Interactions. The corresponding constants from the current UGTA database are provided for comparison.

\begin{tabular}{|c|c|c|c|c|c|c|}
\hline Dataset & $\begin{array}{l}\text { Reaction } \\
\text { Time } \\
\end{array}$ & $\mathrm{CO}_{2}(\mathrm{~g})$ & Reaction & Species & $\begin{array}{c}\text { Revised } \\
\log \mathrm{K} \\
\end{array}$ & $\begin{array}{c}\log \mathrm{K} \text { from } \\
\text { Current UGTA } \\
\text { Database* } \\
\end{array}$ \\
\hline $\mathrm{Pu}(\mathrm{IV})$-gibbsite & $24 \mathrm{~h}$ & free & $\begin{array}{l}\mathrm{AlOH}+\mathrm{Pu}^{4+}+2 \mathrm{H}_{2} \mathrm{O} \leftrightarrow \mathrm{AlOPu}(\mathrm{OH})_{2}{ }^{+}+3 \mathrm{H}^{+} \\
\mathrm{AlOH}+\mathrm{Pu}^{4+}+3 \mathrm{H}_{2} \mathrm{O} \leftrightarrow \mathrm{AlOPu}(\mathrm{OH})_{3}{ }^{\mathrm{o}}+4 \mathrm{H}^{+} \\
\mathrm{AlOH}+\mathrm{Pu}^{4+}+4 \mathrm{H}_{2} \mathrm{O} \leftrightarrow \mathrm{AlOPu}(\mathrm{OH})_{4}{ }^{-}+5 \mathrm{H}^{+}\end{array}$ & $\begin{array}{l}\mathrm{AlOPu}(\mathrm{OH})_{2}{ }^{+} \\
\mathrm{AlOPu}(\mathrm{OH})_{3}{ }^{\mathrm{o}} \\
\mathrm{AlOPu}(\mathrm{OH})_{4}{ }^{-}\end{array}$ & $\begin{array}{c}5.1 \\
-3.37 \\
-12.3\end{array}$ & $\begin{array}{r}5.95 \\
-11.93\end{array}$ \\
\hline $\mathrm{Pu}(\mathrm{IV})$-gibbsite & $24 \mathrm{~h}$ & equilibrated & $\begin{array}{l}\mathrm{AlOH}+\mathrm{Pu}^{4+}+2 \mathrm{H}_{2} \mathrm{O} \leftrightarrow \mathrm{AlOPu}(\mathrm{OH})_{2}{ }^{+}+3 \mathrm{H}^{+} \\
\mathrm{AlOH}+\mathrm{Pu}^{4+}+3 \mathrm{H}_{2} \mathrm{O} \leftrightarrow \mathrm{AlOPu}(\mathrm{OH})_{3}{ }^{\mathrm{O}}+4 \mathrm{H}^{+} \\
\mathrm{AlOH}+\mathrm{Pu}^{4+}+4 \mathrm{H}_{2} \mathrm{O} \leftrightarrow \mathrm{AlOPu}(\mathrm{OH})_{4}{ }^{-}+5 \mathrm{H}^{+}\end{array}$ & $\begin{array}{l}\mathrm{AlOPu}(\mathrm{OH})_{2}{ }^{+} \\
\mathrm{AlOPu}(\mathrm{OH})_{3}{ }^{\mathrm{o}} \\
\mathrm{AlOPu}(\mathrm{OH})_{4}{ }^{-}\end{array}$ & $\begin{array}{r}4.55 \\
-3.52 \\
-9.81\end{array}$ & $\begin{array}{r}5.95 \\
-11.93 \\
\end{array}$ \\
\hline $\mathrm{Pu}(\mathrm{IV})$-gibbsite & $62 d$ & equilibrated & $\begin{array}{l}\mathrm{AlOH}+\mathrm{Pu}^{4+}+2 \mathrm{H}_{2} \mathrm{O} \leftrightarrow \mathrm{AlOPu}(\mathrm{OH})_{2}{ }^{+}+3 \mathrm{H}^{+} \\
\mathrm{AlOH}+\mathrm{Pu}^{4+}+3 \mathrm{H}_{2} \mathrm{O} \leftrightarrow \mathrm{AlOPu}(\mathrm{OH})_{3}{ }^{\circ}+4 \mathrm{H}^{+} \\
\mathrm{AlOH}+\mathrm{Pu}^{4+}+4 \mathrm{H}_{2} \mathrm{O} \leftrightarrow \mathrm{AlOPu}(\mathrm{OH})_{4}{ }^{-}+5 \mathrm{H}^{+}\end{array}$ & $\begin{array}{l}\mathrm{AlOPu}(\mathrm{OH})_{2}{ }^{+} \\
\mathrm{AlOPu}(\mathrm{OH})_{3}{ }^{\circ} \\
\mathrm{AlOPu}(\mathrm{OH})_{4}{ }^{-}\end{array}$ & $\begin{array}{r}4.16 \\
-2.64 \\
-9.47 \\
\end{array}$ & $\begin{array}{r}5.95 \\
-11.93 \\
\end{array}$ \\
\hline $\mathrm{Pu}(\mathrm{IV})$-silica & $24 \mathrm{~h}$ & equilibrated & $\begin{array}{l}\mathrm{SiOH}+\mathrm{Pu}^{4+}+2 \mathrm{H}_{2} \mathrm{O} \leftrightarrow \mathrm{SiOPu}(\mathrm{OH})_{2}{ }^{+}+3 \mathrm{H}^{+} \\
\mathrm{SiOH}+\mathrm{Pu}^{4+}+3 \mathrm{H}_{2} \mathrm{O} \leftrightarrow \mathrm{SiOPu}(\mathrm{OH})_{3}{ }^{0}+4 \mathrm{H}^{+} \\
\mathrm{SiOH}+\mathrm{Pu}^{4+}+4 \mathrm{H}_{2} \mathrm{O} \leftrightarrow \mathrm{SiOPu}(\mathrm{OH})_{4}{ }^{-}+5 \mathrm{H}^{+}\end{array}$ & $\begin{array}{l}\mathrm{SiOPu}(\mathrm{OH})_{2}{ }^{+} \\
\mathrm{SiOPu}(\mathrm{OH})_{3}{ }^{\mathrm{o}} \\
\mathrm{SiOPu}(\mathrm{OH})_{4}{ }^{-}\end{array}$ & $\begin{array}{c}-3.55 \\
-9.05^{\#},-10.71\end{array}$ & 2.32 \\
\hline $\mathrm{Pu}(\mathrm{IV})$-silica & $62 d$ & equilibrated & $\begin{array}{l}\mathrm{SiOH}+\mathrm{Pu}^{4+}+2 \mathrm{H}_{2} \mathrm{O} \leftrightarrow \mathrm{SiOPu}(\mathrm{OH})_{2}{ }^{+}+3 \mathrm{H}^{+} \\
\mathrm{SiOH}+\mathrm{Pu}^{4+}+3 \mathrm{H}_{2} \mathrm{O} \leftrightarrow \mathrm{SiOPu}(\mathrm{OH})_{3}{ }^{\circ}+4 \mathrm{H}^{+} \\
\mathrm{SiOH}+\mathrm{Pu}^{4+}+4 \mathrm{H}_{2} \mathrm{O} \leftrightarrow \mathrm{SiOPu}(\mathrm{OH})_{4}{ }^{-}+5 \mathrm{H}^{+}\end{array}$ & $\begin{array}{l}\mathrm{SiOPu}(\mathrm{OH})_{2}^{+} \\
\mathrm{SiOPu}(\mathrm{OH})_{3}{ }^{\circ} \\
\mathrm{SiOPu}(\mathrm{OH})_{4}^{-}\end{array}$ & $\begin{array}{c}-3.94 \\
-8.77^{\#},-9.07\end{array}$ & \\
\hline $\mathrm{Pu}(\mathrm{V})$-gibbsite & $24 \mathrm{~h}$ & free & $\begin{array}{c}\mathrm{AlOH}+\mathrm{PuO}_{2}^{+} \leftrightarrow \mathrm{AlOHPuO}_{2}^{+} \\
\mathrm{AlOH}+\mathrm{PuO}_{2}^{+} \leftrightarrow \mathrm{AlOPuO}_{2}{ }^{\circ}+\mathrm{H}^{+} \\
\mathrm{AlOH}+\mathrm{H}_{2} \mathrm{O}+\mathrm{PuO}_{2}^{+} \leftrightarrow \mathrm{AlOPuO}_{2} \mathrm{OH}^{-}+2 \mathrm{H}^{+}\end{array}$ & $\begin{array}{c}\mathrm{AlOHPuO}_{2}^{+} \\
\mathrm{AlOPuO}_{2}{ }^{\circ} \\
\mathrm{AlOPuO}_{2} \mathrm{OH}^{-}\end{array}$ & $\begin{array}{r}5.36 \\
-3.09 \\
-11.6 \\
\end{array}$ & -3.09 \\
\hline $\mathrm{Pu}(\mathrm{V})$-silica & $24 \mathrm{~h}$ & free & $\begin{array}{c}\mathrm{SiOH}+\mathrm{PuO}_{2}^{+} \leftrightarrow \mathrm{SiOHPuO}_{2}^{+} \\
\mathrm{SiOH}+\mathrm{PuO}_{2}^{+} \leftrightarrow \mathrm{SiOPuO}_{2}{ }^{\circ}+\mathrm{H}^{+} \\
\mathrm{SiOH}+\mathrm{H}_{2} \mathrm{O}+\mathrm{PuO}_{2}^{+} \leftrightarrow \mathrm{SiOPuO}_{2} \mathrm{OH}^{-}+2 \mathrm{H}^{+}\end{array}$ & $\begin{array}{l}\mathrm{SiOHPuO}_{2}^{+} \\
\mathrm{SiOPuO}_{2}{ }^{\mathrm{o}} \\
\mathrm{SiOPuO}_{2} \mathrm{OH}^{-}\end{array}$ & $\begin{array}{r}4.11 \\
-1.10 \\
-11.3\end{array}$ & $\begin{array}{l}-6.43 \\
-14.80\end{array}$ \\
\hline
\end{tabular}




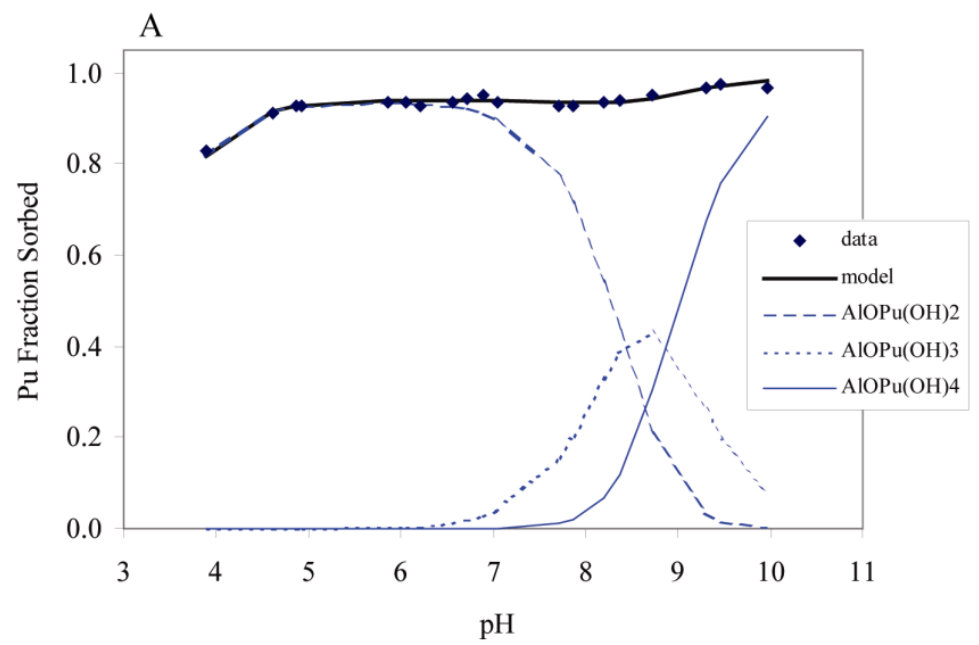

B
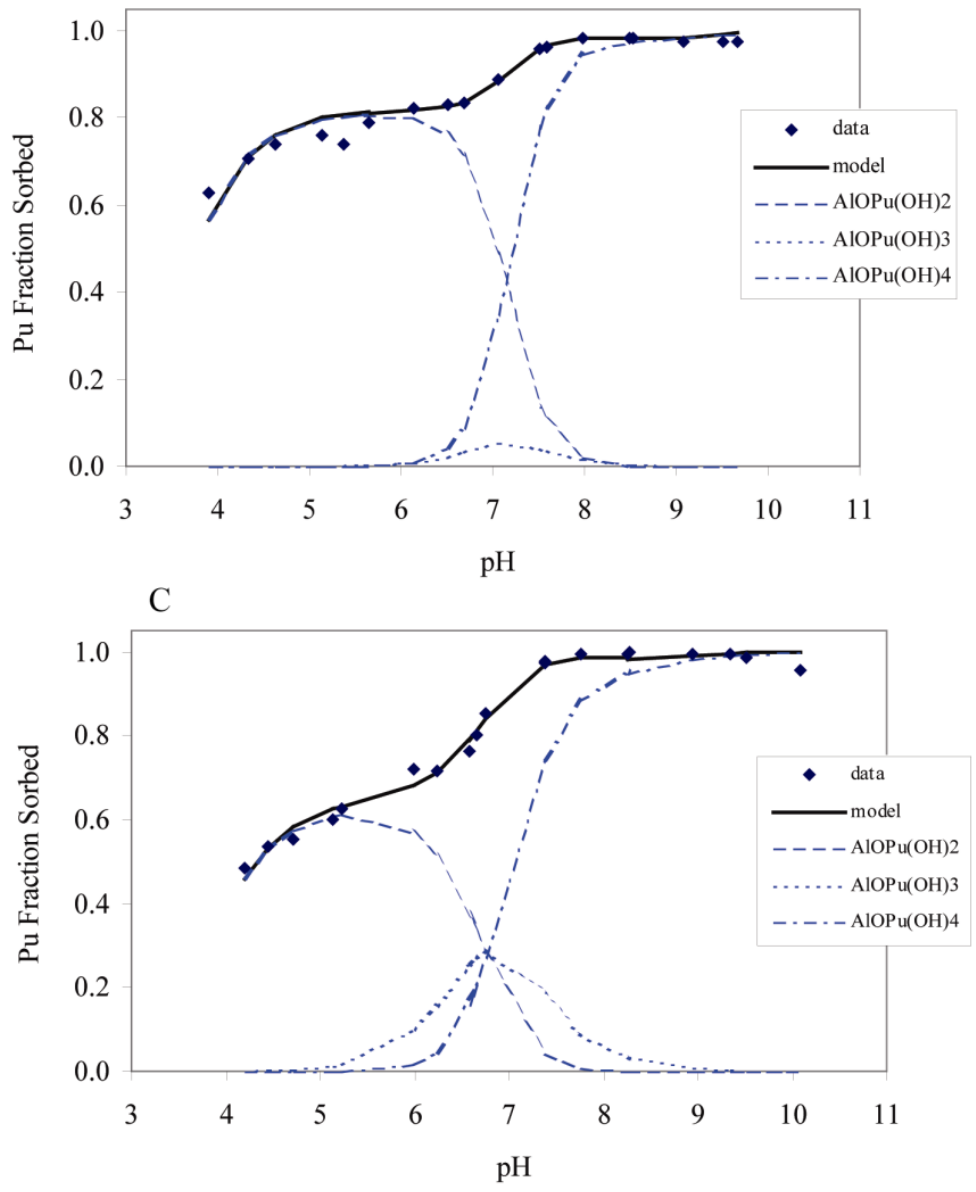

Figure 4.4: Sorption of $\mathrm{Pu}(\mathrm{IV})$ to gibbsite for (A) 24 hours $\mathrm{CO}_{2}$ (g)-free (B) 24 hours $\mathrm{CO}_{2}$ (g)-equilibrated, and (C) 62 days $\mathrm{CO}_{2}(\mathrm{~g})$-equilibrated sorption data. Solid black lines represent total model fit to data and broken blue lines represent individual species distribution within model. 
The $\log \mathrm{K}$ values for the $\mathrm{Pu}$ species predominating at high $\mathrm{pH}$ vary significantly due to the influence of carbonate when determining the constants. The $\log \mathrm{K}$ of -12.3 obtained from the 24hour $\mathrm{CO}_{2}(\mathrm{~g})$-free dataset is most consistent with the value of -11.93 from the current UGTA database. The $\log \mathrm{K}$ constants of -9.8 and -9.5 for the $\mathrm{CO}_{2}(\mathrm{~g})$-equilibrated datasets after 24 hours and 62 days, respectively, appear to be artificially low due to inclusion of carbonate species when determining the constants. In the high $\mathrm{pH}$ regions, there does not appear to be an observable difference in the sorption behavior in $\mathrm{CO}_{2}(\mathrm{~g})$-free and $\mathrm{CO}_{2}(\mathrm{~g})$-equilibrated systems. Therefore, either $\mathrm{Pu}(\mathrm{IV})$-carbonate/hydroxycarbonate species have similar sorption affinities as $\mathrm{Pu}(\mathrm{IV})$-hydroxides or aqueous $\mathrm{Pu}(\mathrm{IV})$-carbonates/hydroxycarbonates did not form in sufficient quantities to significantly affect sorption. The $\log \mathrm{K}$ values determined for $\mathrm{CO}_{2}$ (g)-equilibrated systems may have been artificially increased to negate the formation of $\mathrm{Pu}(\mathrm{IV})$ carbonates/hydroxycarbonates.

\subsubsection{Pu(IV) Sorption to Silica}

As discussed above, the current UGTA database is unable to accurately predict $\mathrm{Pu}$ sorption to silica since $\mathrm{SiOPu}(\mathrm{OH})_{2}{ }^{+}$is the only assumed surface species and it is not predicted to sorb at high $\mathrm{pH}$ values. Attempts to fit the data with only $\mathrm{SiOPu}(\mathrm{OH})_{2}{ }^{+}$were unsuccessful. The best model fits were obtained assuming $\mathrm{SiOPu}(\mathrm{OH})_{3}{ }^{\mathrm{o}}$ and $\mathrm{SiOPu}(\mathrm{OH})_{4}{ }^{-}$as the sorbing species. An acceptable fit to the data could also be achieved by including $\mathrm{SiOPu}(\mathrm{OH})_{2}{ }^{+}$as a sorbing species but $\mathrm{SiOPu}(\mathrm{OH})_{3}{ }^{\circ}$ provided a better fit to the data. Based on known $\mathrm{Pu}(\mathrm{IV})$ solution chemistry, the predominance of a fully hydrolyzed $\mathrm{Pu}(\mathrm{IV})$ hydroxide species at the silica surface at circumneutral $\mathrm{pH}$ is more plausible.

Constants for $\mathrm{Pu}(\mathrm{IV})$-silanol species were only determined for the datasets equilibrated with carbonate. As discussed above, the data from $\mathrm{CO}_{2}(\mathrm{~g})$-free experiments are proposed to contain a significant fraction of $\mathrm{Pu}(\mathrm{V})$ and therefore be unrepresentative of $\mathrm{Pu}(\mathrm{IV})$ sorption. This is supported by the measurement of $\mathrm{Pu}(\mathrm{V} / \mathrm{VI})$ as the predominant oxidation state of aqueous $\mathrm{Pu}$ in low $\mathrm{pH}$ silica suspensions. Therefore, the most reliable data are from the $\mathrm{CO}_{2}(\mathrm{~g})$-equilibrated dataset after 62 days as it contained the largest fraction of $\mathrm{Pu}(\mathrm{IV})$. This assumption is supported by the convergence of the initially $\mathrm{Pu}(\mathrm{IV})$ and initially- $\mathrm{Pu}(\mathrm{V})$ datasets after 62 days. The model fits for the $\mathrm{CO}_{2}(\mathrm{~g})$-equilibrated dataset after 24 hours are shown for reference. Both datasets yielded similar $\log \mathrm{K}$ values. The $\log \mathrm{K}$ for $\mathrm{SiOPu}\left(\mathrm{OH}_{3}\right)^{\mathrm{o}}$ decreased from -3.55 to -3.94 due to the slight desorption of Pu observed in these systems over between 24 hours and 62 days, respectively. Since the aqueous Pu was determined to be predominantly $\mathrm{Pu}(\mathrm{IV})$, the higher $\log \mathrm{K}$ value of -3.55 from the 24 hour dataset is proposed to be more representative of $\mathrm{Pu}(\mathrm{IV})$. There was a more significant difference in the $\log \mathrm{K}$ values for $\mathrm{SiOPu}(\mathrm{OH})_{4}{ }^{-}$. As discussed for the gibbsite datasets above, formation of $\mathrm{Pu}(\mathrm{OH})_{2}\left(\mathrm{CO}_{3}\right)_{2}{ }^{2-}$ significantly affects the results. For the 62 day dataset, the $\log \mathrm{K}$ decreased from -8.77 to -9.07 when $\mathrm{Pu}(\mathrm{OH})_{2}\left(\mathrm{CO}_{3}\right)_{2}{ }^{2-}$ was excluded. For the 24 day dataset, $\mathrm{Pu}(\mathrm{OH})_{2}\left(\mathrm{CO}_{3}\right)_{2}{ }^{2-}$ has a greater effect on the sorption constants due to the higher concentration of aqueous $\mathrm{Pu}$ at high $\mathrm{pH}$ values. The similarity of the values for both datasets when $\mathrm{Pu}(\mathrm{OH})_{2}\left(\mathrm{CO}_{3}\right)_{2}{ }^{2-}$ is included indicates that the most accurate value may be approximately -9 . 


\subsection{3 $\quad \mathrm{Pu}(\mathrm{V})$ Sorption to Gibbsite}

Sorption constants for $\mathrm{Pu}(\mathrm{V})$-aluminol species were determined from the dataset obtained after 24 hours. Again, the assumption in this modeling effort is that surface mediated reduction of $\mathrm{Pu}(\mathrm{V})$ to $\mathrm{Pu}(\mathrm{IV})$ is kinetically hindered and the data are most representative of $\mathrm{Pu}(\mathrm{V})$ sorption. A good fit was obtained assuming three surface complexes as noted in Table 4.4. The model fit is shown in Figure 4.6a. The current model includes only one sorbing species, $\mathrm{AlOPuO}_{2}{ }^{\mathrm{o}}$ with a $\log$ $\mathrm{K}$ of -3.09 . Attempts to model the $\mathrm{Pu}(\mathrm{V})$-gibbsite sorption data with only one species were unsuccessful.
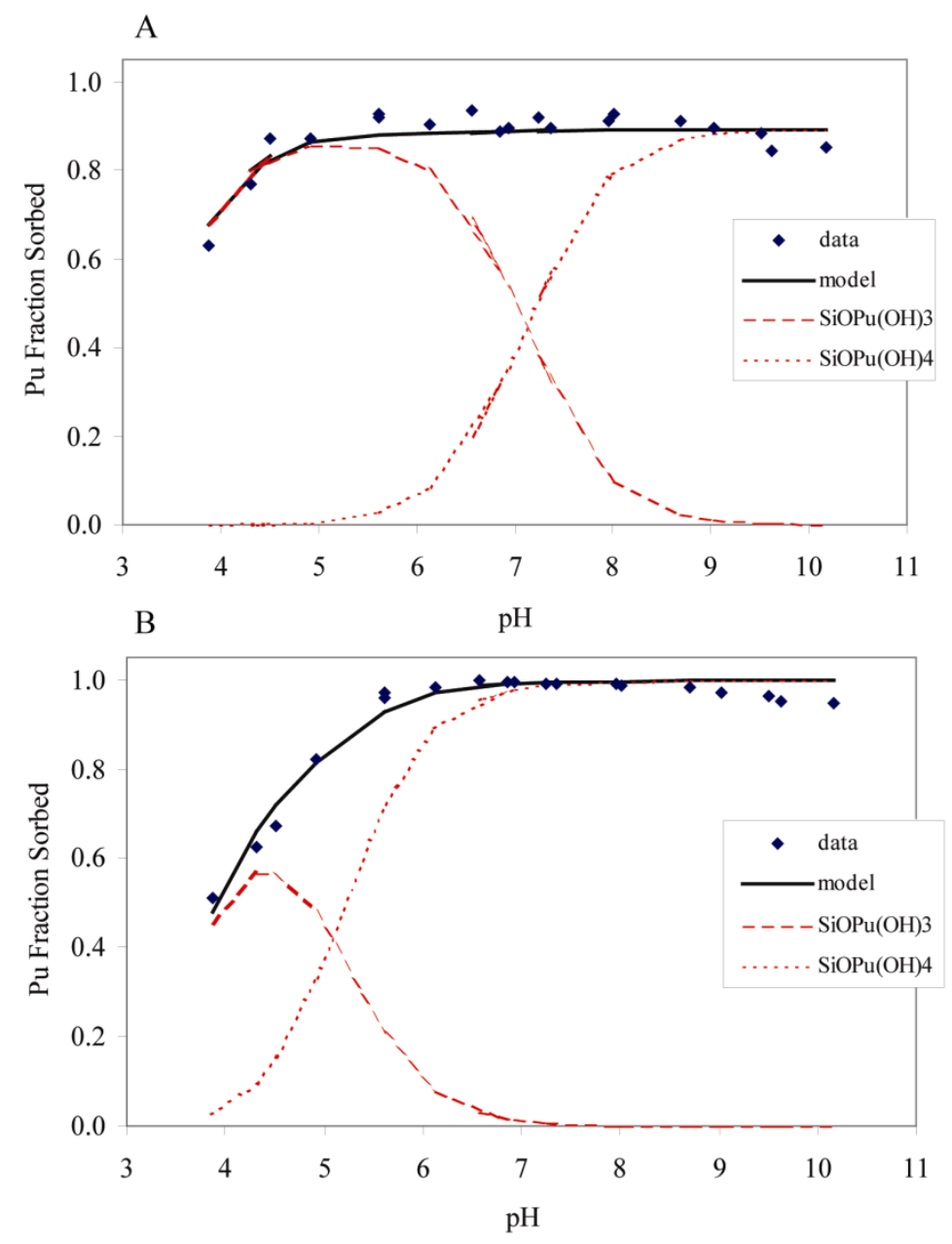

Figure 4.5: Sorption of $\mathrm{Pu}(\mathrm{IV})$ to silica under the following conditions a). 24 hours, $\mathrm{CO}_{2}$ (g)-equilibrated and b). 62 days, $\mathrm{CO}_{2}(\mathrm{~g})$-equilibrated. Solid black lines represent total model fit to data and broken red lines represent individual species distribution within model.

The $\log \mathrm{K}$ value of $\mathrm{AlOPuO}_{2}{ }^{ }$was fixed at -3.09 to remain consistent with the current UGTA database and the constants for $\mathrm{AlOHPuO}_{2}{ }^{+}$and $\mathrm{AlOPuO}_{2} \mathrm{OH}^{-}$were fitted (Figure 4.6a). Using these constants to predict the effect of carbonate on $\mathrm{Pu}(\mathrm{V})$ sorption to gibbsite resulted in a reasonable fit to the data (Figure 4.6b). The model accurately predicts the "sorption edge" and 
general shape of the curve. It is noteworthy that the $\mathrm{HCO}_{3}{ }^{-} / \mathrm{CO}_{3}{ }^{2-}$ concentration used in these experiments is in equilibrium with atmosphereic $\mathrm{CO}_{2}(\mathrm{~g})$ up to $\mathrm{pH} 9$. Thereafter, the concentration is limited to $10 \mathrm{mM}$ total carbonate. There is a notable divergence between $\mathrm{CO}_{2}(\mathrm{~g})$-free and $\mathrm{CO}_{2}(\mathrm{~g})$-equilibrated $\mathrm{Pu}(\mathrm{V})$ systems at $\mathrm{pH} 7$ to 8 as the formation of $\mathrm{Pu}(\mathrm{V})$ carbonate complexes becomes favorable. As the $\mathrm{pH}$ rises above 8, competition between formation of $\mathrm{Pu}(\mathrm{V})$-carbonates and $\mathrm{Pu}(\mathrm{V})$-hydroxide occurs and the effect of carbonate on $\mathrm{Pu}(\mathrm{V})$ sorption is diminished.
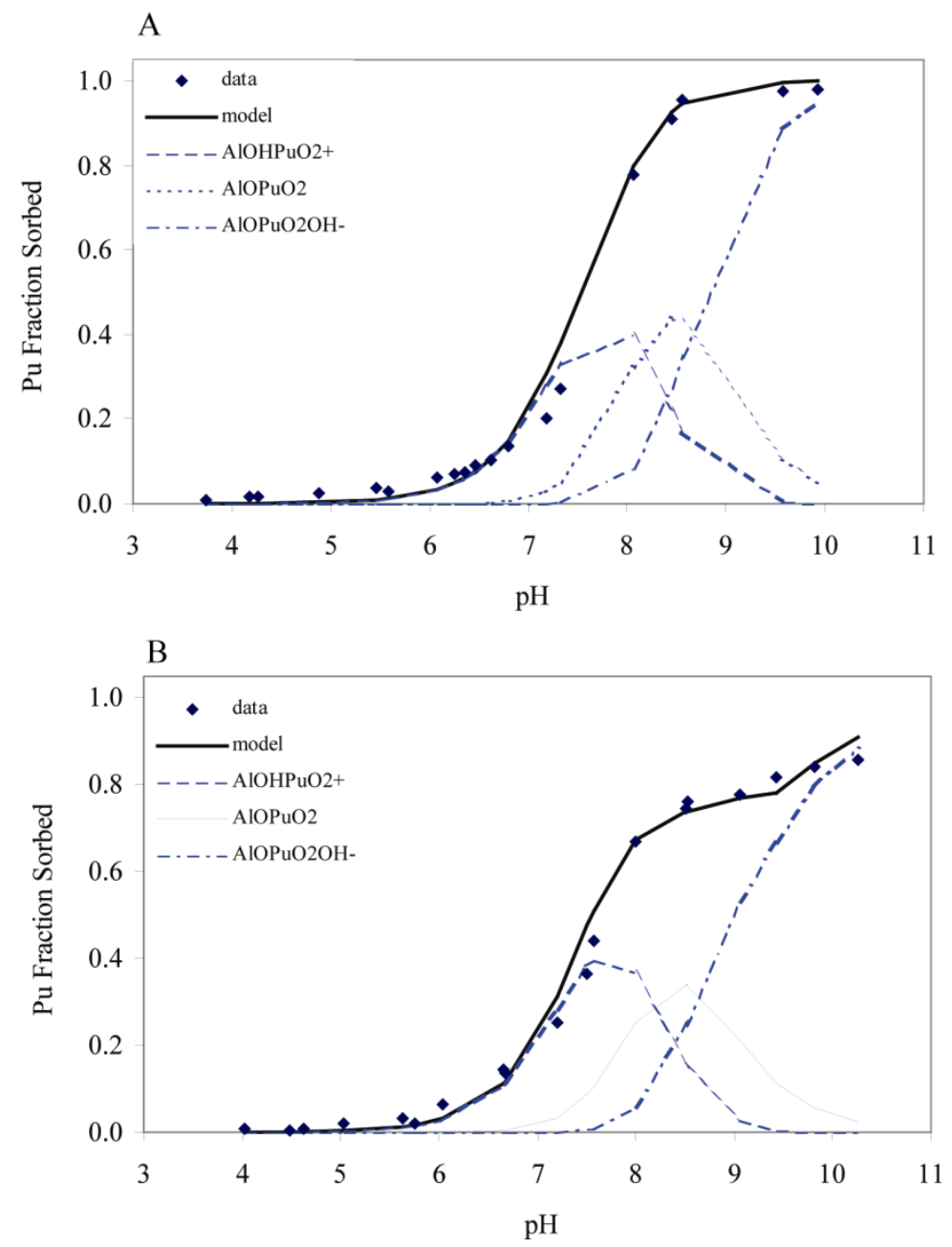

Figure 4.6: Sorption of $\mathrm{Pu}(\mathrm{V})$ to gibbsite after 24 hours for $(\mathrm{A}) \mathrm{CO}_{2}(\mathrm{~g})$-free and (B) $\mathrm{CO}_{2}(\mathrm{~g})$-equilibrated sorption data. Solid black lines represent total model fit to data and broken red lines represent individual species distribution within model.

\subsubsection{Pu(V) Sorption to Silica}

$\mathrm{Pu}(\mathrm{V})$ sorption to silica was accurately modeled assuming three solid phase species, $\mathrm{SiOHPuO}_{2}^{+}$, $\mathrm{SiOPuO}_{2}{ }^{0}$, and $\mathrm{SiOPuO}_{2} \mathrm{OH}^{-}$. The $\log \mathrm{K}$ values for the $\mathrm{SiOPuO}_{2}{ }^{\mathrm{o}}$ and $\mathrm{SiOPuO}_{2} \mathrm{OH}^{-}$species are 5.3 and 3.5 orders of magnitude higher, respectively, than the corresponding species in the 
current UGTA database. $\mathrm{Pu}(\mathrm{V})$ sorption was drastically under-predicted using the current UGTA database (Figures 4.2c and 4.2d). Efforts to model the data using only the two $\mathrm{Pu}(\mathrm{V})$-silanol species assumed in the current UGTA database provided a good fit to the data in the high $\mathrm{pH}$ region but overpredicted sorption at neutral $\mathrm{pH}$ values. Therefore, an additional sorbing species was added, $\mathrm{SiOHPuO}_{2}{ }^{+}$. The single datapoint at $\mathrm{pH} 4$ was found to be very influential on the log $\mathrm{K}$ value for $\mathrm{SiOHPuO}_{2}{ }^{+}$and impeded model convergence. The $\mathrm{SiOHPuO}_{2}{ }^{+}$species was manually adjusted to -4.1 to achieve the fit shown in Figure 4.7. Alternatively, by omitting the single datapoint at $\mathrm{pH} 4$, FIT4FD was able to converge on all three surface species. The log $\mathrm{K}$ values for $\mathrm{SiOPuO}_{2}{ }^{\mathrm{o}}$ and $\mathrm{SiOPuO}_{2} \mathrm{OH}^{-}$did not significantly change but the log $\mathrm{K}$ for $\mathrm{SiOHPuO}_{2}{ }^{+}$ increased to 4.4. Due to the sensitivity of the $\log \mathrm{K}_{\text {value for }} \mathrm{SiOHPuO}_{2}{ }^{+}$, an error of at least 0.5 $\log$ units is recommended. It is noteworthy that the sensitivity of this value is also linked to the assumed $\mathrm{SiOH}$ deprotonation constant of -7.0. As shown in Figure 4.7b, the revised constants were able to accurately predict the effect of carbonate on $\mathrm{Pu}(\mathrm{V})$ sorption to silica.
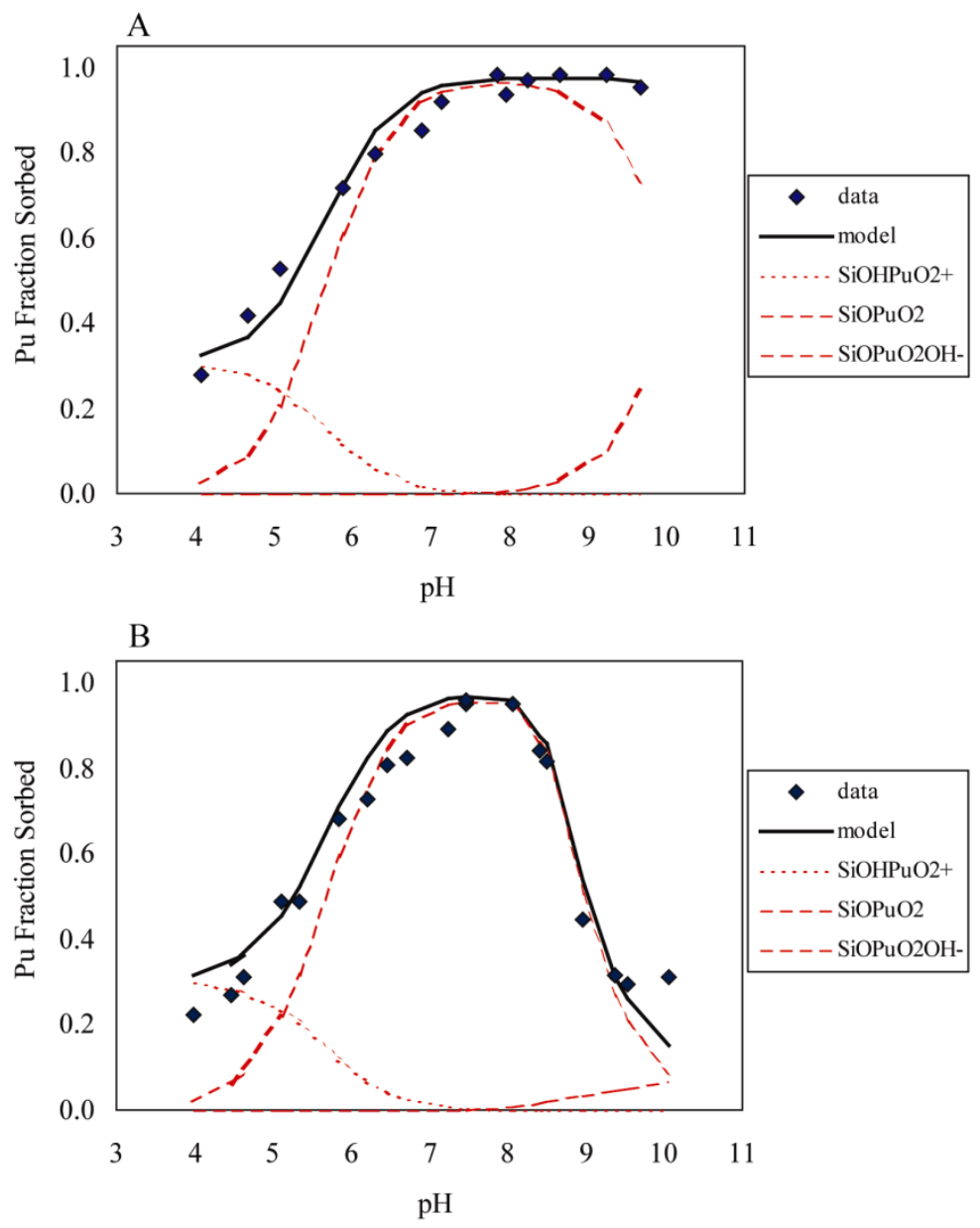

Figure 4.7: Sorption of $\mathrm{Pu}(\mathrm{V})$ to silica after 24 hours for $(\mathrm{A}) \mathrm{CO}_{2}(\mathrm{~g})$-free and (B) $\mathrm{CO}_{2}(\mathrm{~g})$-equilibrated sorption data. Solid black lines represent total model fit to data and broken red lines represent individual species distribution within model. 


\subsection{Modeling Pu Sorption to Montmorillonite using Revised Sorption Constants}

\subsubsection{Pu(V) Sorption to Montmorillonite}

The $\mathrm{Pu}(\mathrm{V})$-silanol and $\mathrm{Pu}(\mathrm{V})$-aluminol constants listed in Table 4.5 were selected from the modeling effort described above to perform predictive modeling of the $\mathrm{Pu}(\mathrm{V})$-montmorillonite sorption data. These constants were selected as the most reliable based on the discussion above. The constants were utilized in FIT4FD along with the montmorillonite surface data listed in Table 4.3 to generate the model shown in Figure 4.8a. All constants and surface site concentrations were fixed in this model to evaluate how well constants derived from silica and gibbsite sorption data could predict $\mathrm{Pu}(\mathrm{V})$ sorption to montmorillonite. As shown in Figure 4.8a, the model approximates the shape of the sorption curve but does not accurately predict the data. The model overpredicts sorption in the $\mathrm{pH}$ range 6 to 8 through predominance of $\mathrm{SiOPuO}_{2}{ }^{\circ}$. Additionally, the model underpredicts sorption at high $\mathrm{pH}$ values and is not able to accurately fit the slight decrease in sorption at $\mathrm{pH}$ greater than 9.

Additional modeling exercises were preformed to determine sensitivity of log K values (Table 4.5). Reasonable fits to the data were achieved in two cases. In both cases, the constant for $\mathrm{SiOPuO}_{2}{ }^{\mathrm{O}}$ was changed to approximately -1.9 . However reasonable fits to the high $\mathrm{pH}$ data were achieved by adjusting the log $\mathrm{K}$ values for either $\mathrm{SiOPuO}_{2} \mathrm{OH}^{-}$or $\mathrm{AlOPuO}_{2} \mathrm{OH}^{-}$(Table 4.5). The best fit was obtained by adjusting $\mathrm{SiOPuO}_{2}{ }^{\circ}$ and $\mathrm{AlOPuO}_{2} \mathrm{OH}^{-}$simultaneously. The model fit using these constants is shown in Figure $4.8 \mathrm{~b}$. It is important to note that this is purely a fitting exercise with no evidence to support preferentially modifying either Pu-aluminol or Pu-silanol surface complexation constants. Using the constants from "Adjusted Model 1" (Table 4.5), the effect of $\mathrm{CO}_{2}(\mathrm{~g})$ was reasonably predicted as shown in Figure 4.9.

Overall, the use of sorption constants derived from $\mathrm{Pu}(\mathrm{V})$-gibbsite and $\mathrm{Pu}(\mathrm{V})$-silica experiments appears to be capable of qualitatively predicting sorption of $\mathrm{Pu}(\mathrm{V})$ to montmorillonite. By adjusting two constants by approximately one log unit, a substantially better fit to the data could be achieved.

Table 4.5: $\mathrm{Pu}(\mathrm{V})$ - Surface Complexation Constants Used in Montmorillonite Sorption Modeling

\begin{tabular}{ccccc}
\hline Dataset & Species & $\begin{array}{c}\text { Selected Constants } \\
\text { from Table 4.4 }\end{array}$ & $\begin{array}{c}\text { Adjusted } \\
\text { Model 1 }\end{array}$ & $\begin{array}{c}\text { Adjusted } \\
\text { Model 2 }\end{array}$ \\
\hline \hline $\mathrm{Pu}(\mathrm{V})$-gibbsite & $\mathrm{AlOHPuO}_{2}^{+}$ & 5.36 & same, fixed & same, fixed \\
& $\mathrm{AlOPuO}_{2}$ & -3.09 & same, fixed & same, fixed \\
& $\mathrm{AlOPuO}_{2}(\mathrm{OH})^{-}$ & -11.6 & -10.5 & same, fixed \\
\hline $\mathrm{Pu}(\mathrm{V})$-silica & $\mathrm{SiOHPuO}_{2}^{+}$ & 4.11 & same, fixed & same, fixed \\
& $\mathrm{SiOPuO}_{2}$ & -1.1 & -1.91 & -1.94 \\
& $\mathrm{SiOPuO}_{2} \mathrm{OH}^{-}$ & -11.3 & same, fixed & -9.95 \\
\hline
\end{tabular}



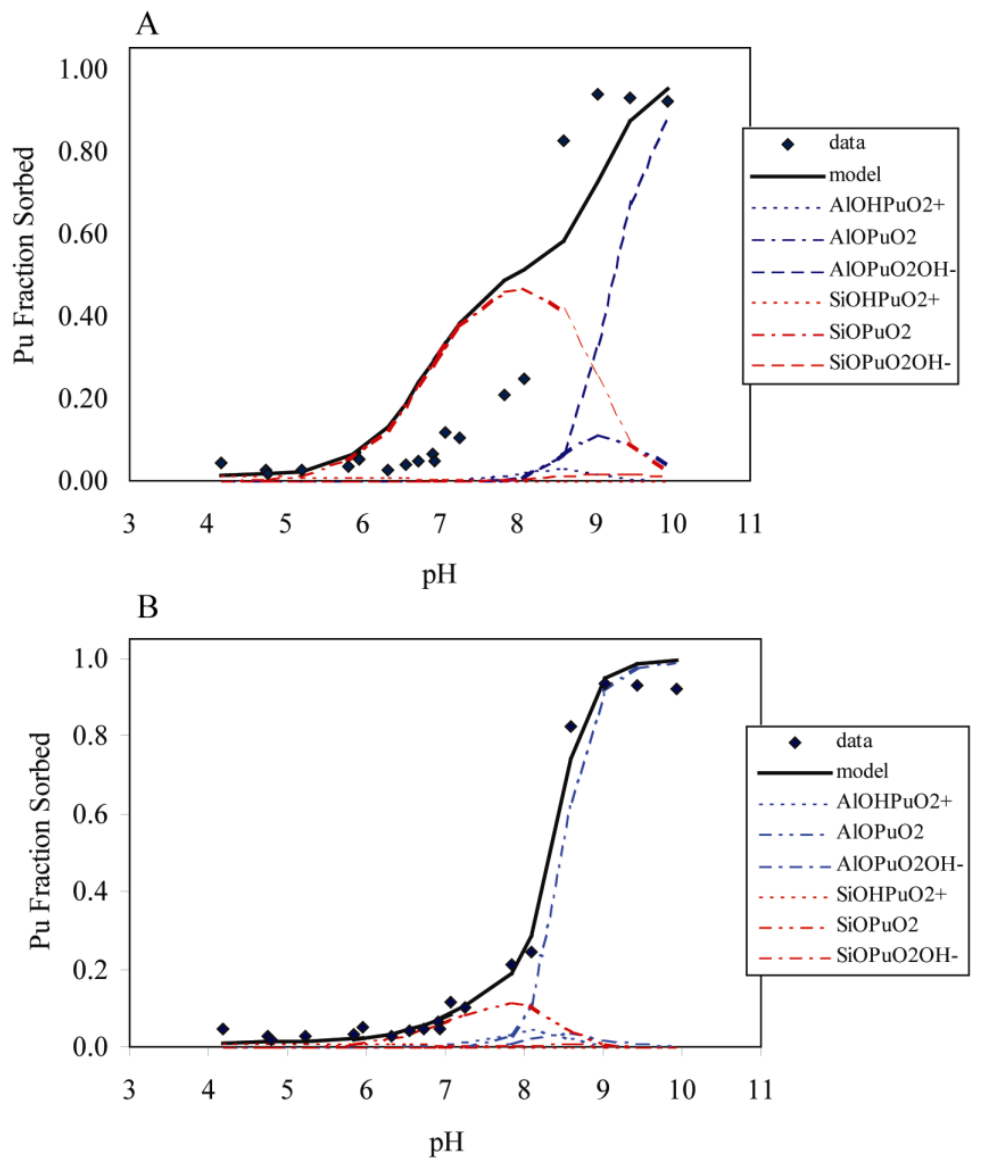

Figure 4.8: $\mathrm{Pu}(\mathrm{V})$ sorption to montmorillonite under $\mathrm{CO}_{2}(\mathrm{~g})$ free conditions after 24 hours using $(\mathrm{A})$ constants determined from $\mathrm{Pu}(\mathrm{V})$-gibbsite and $\mathrm{Pu}(\mathrm{V})$-silica studies and (B) revised constants for $\mathrm{SiOPuO}_{2}{ }^{\circ}$ and $\mathrm{AlOPuO}_{2} \mathrm{OH}^{-}$. Surface complexation constants used in model are listed in Table 4.5.

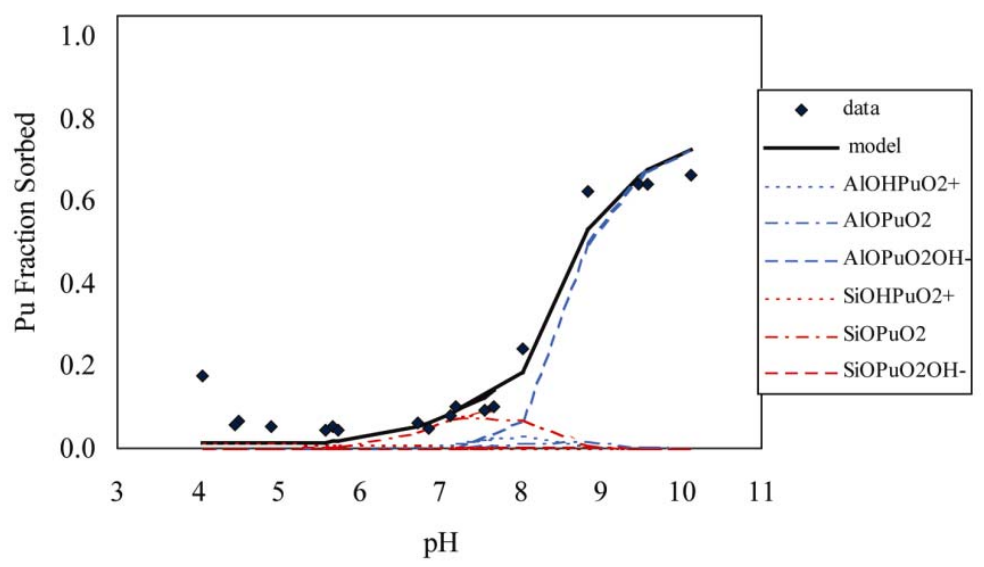

Figure 4.9: Prediction of $\mathrm{Pu}(\mathrm{V})$ sorption to montmorillonite after 24 hours under $\mathrm{CO}_{2}(\mathrm{~g})$ equilibrated conditions using adjusted model constants listed in Table 4.4. 


\subsection{2 $\mathrm{Pu}(\mathrm{IV})$ Sorption to Montmorillonite}

Predictions of $\mathrm{Pu}(\mathrm{IV})$ sorption to montmorillonite are shown in Figure 4.9. The $\mathrm{Pu}(\mathrm{IV})$-aluminol and $\mathrm{Pu}(\mathrm{IV})$-silanol constants selected from the silica and gibbsite model fits are listed in Table 4.6. Overall the model did a poor job of fitting using the $\mathrm{Pu}(\mathrm{IV})$-aluminol and $\mathrm{Pu}(\mathrm{IV})$-silanol constants determined from gibbsite and silica studies. At low $\mathrm{pH}$, sorption of $\mathrm{Pu}$ was drastically under-predicted and at high $\mathrm{pH}$ sorption was over-predicted.

Some additional modeling exercises were performed to determine sensitivity of $\log \mathrm{K}$ values. The surface complexation constants determined from some of these exercises are listed in Table 4.6 and fits to the data are shown in Figure 4.10. When performing these modeling exercises, not all surface species were considered at once. Within individual exercises, only selected surface complexes were considered. From Figure 4.10, it is clear that acceptable fits to the data can be obtained using several non-unique sets of constants.
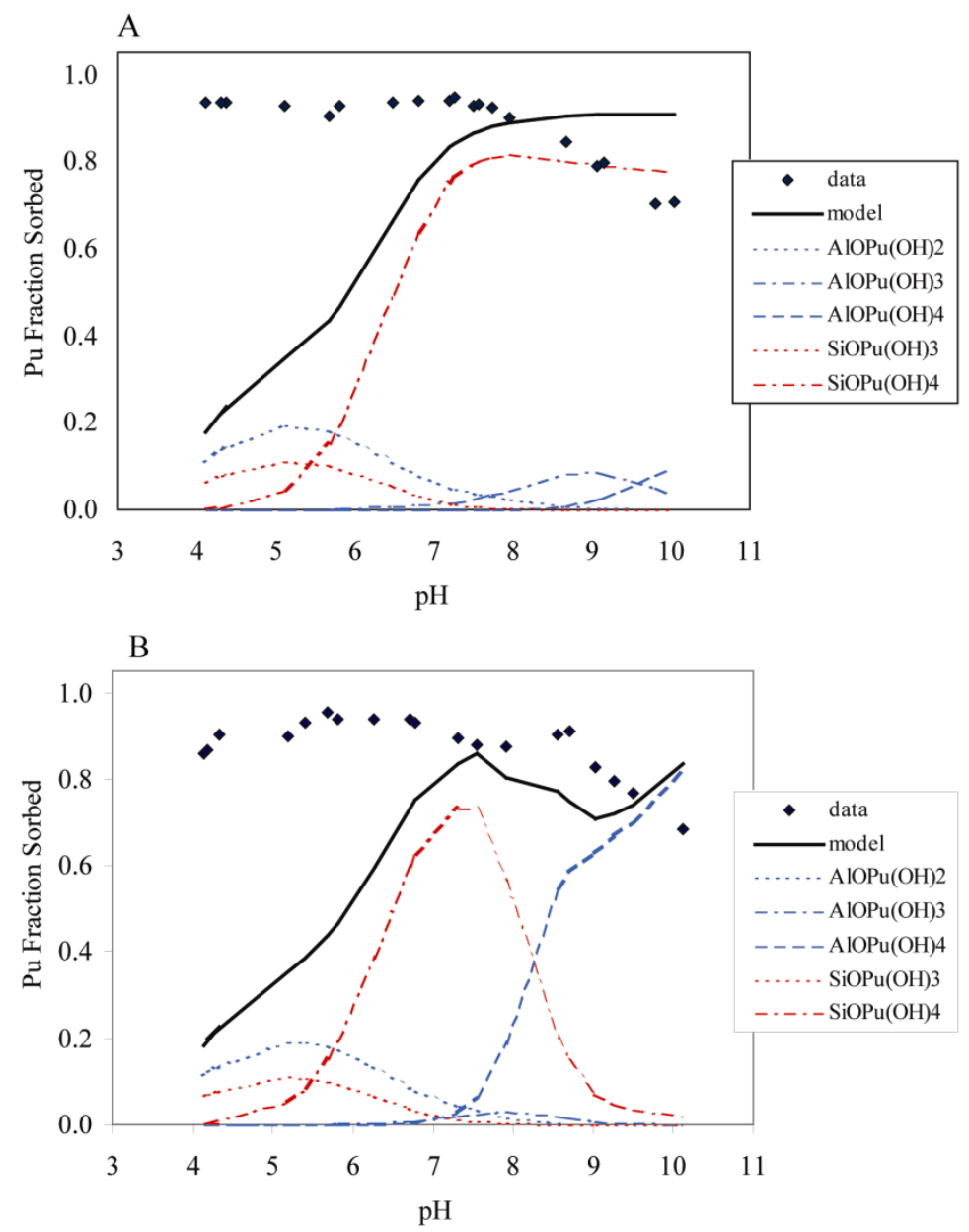

Figure 4.9: $\mathrm{Pu}(\mathrm{IV})$ sorption to montmorillonite after 24 hours under $(\mathrm{A}) \mathrm{CO}_{2}(\mathrm{~g})$-free and $(\mathrm{B}) \mathrm{CO}_{2}(\mathrm{~g})$-equilibrated conditions using constants determined from $\mathrm{Pu}(\mathrm{IV})$-gibbsite and $\mathrm{Pu}(\mathrm{IV})$-silica studies. Surface complexation constants used in model are listed in Table 4.6. 
Table 4.6: $\mathrm{Pu}(\mathrm{IV})$ Surface Complexation Constants Used in Montmorillonite Sorption Modeling

\begin{tabular}{|c|c|c|c|c|c|c|c|c|}
\hline Species & $\begin{array}{c}\text { Selected for } \\
\text { Montmorillonite } \\
\text { Sorption } \\
\text { Modeling } \\
\end{array}$ & $\begin{array}{l}\text { Adjusted } \\
\text { Model } 1 \\
\end{array}$ & $\begin{array}{l}\text { Adjusted } \\
\text { Model } 2 \\
\end{array}$ & $\begin{array}{l}\text { Adjusted } \\
\text { Model } 3 \\
\end{array}$ & $\begin{array}{c}\text { Adjusted } \\
\text { Model } 4\end{array}$ & $\begin{array}{c}\text { Adjusted } \\
\text { Model } 5\end{array}$ & $\begin{array}{c}\text { Adjusted } \\
\text { Model } 6\end{array}$ & $\begin{array}{c}\text { Adjusted } \\
\text { Model } 7\end{array}$ \\
\hline $2 \mathrm{AlOPu}(\mathrm{OH})_{2}{ }^{+}$ & $\overline{5.10}$ & & 6.93 & & 6.66 & 6.93 & 26.61 & \\
\hline $\mathrm{AlOPu}(\mathrm{OH})_{3}{ }^{\circ}$ & -2.64 & & & -2.07 & -1.98 & & & \\
\hline $\mathrm{AlOPu}(\mathrm{OH})_{4}^{-}$ & -12.3 & & -11.92 & -12.45 & & & & -11.97 \\
\hline $\mathrm{SiOPu}(\mathrm{OH})_{2}^{+}$ & & 2.66 & 2.27 & & 2.70 & & & \\
\hline $\mathrm{SiOPu}(\mathrm{OH})_{3}{ }^{\circ}$ & -3.55 & & & -1.27 & & & -1.80 & -0.46 \\
\hline $\mathrm{SiOPu}(\mathrm{OH})_{4}^{-}$ & -9.10 & -9.67 & & & & -9.69 & -9.66 & \\
\hline
\end{tabular}

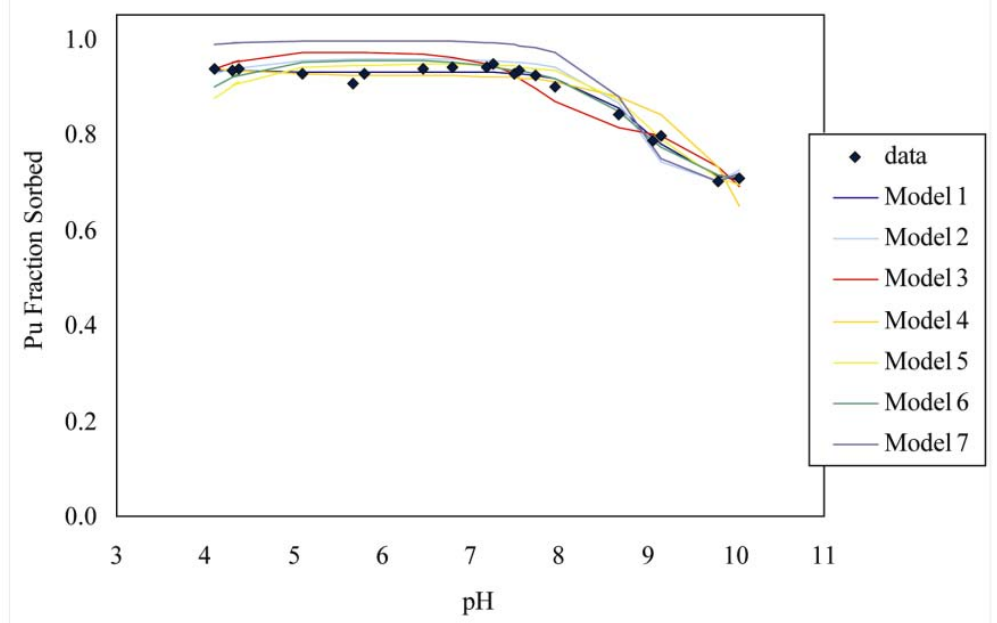

Figure 4.10: Additional model fits to $\mathrm{Pu}(\mathrm{IV})$ montmorillonite sorption data assuming various $\mathrm{Pu}(\mathrm{IV})$ surface complexes as listed in Table 4.6.

Finding multiple solutions to a sorption dataset is a common problem in surface complexation modeling. Turner et al. (1998) calculated $\mathrm{Np}$-silanol and $\mathrm{Np}$-aluminol surface complexation constants based solely on montmorillonite sorption data. A good fit was achieved using only two species: $\mathrm{AlONpO}_{2}{ }^{\mathrm{O}}$ and $\mathrm{SiOHNpO}_{2}{ }^{+}$. However, the possibility of this being a non-unique solution was not discussed. These surface complexation constants cannot be assumed to represent true surface species as they represent non-unique solutions. However, general trends can be observed. In order to account for the drastic under-prediction of $\mathrm{Pu}$ sorption at low $\mathrm{pH}$, the $\log \mathrm{K}$ values for the $\mathrm{SiOPu}(\mathrm{OH})_{3}{ }^{0}$ and $\mathrm{AlOPu}(\mathrm{OH})_{2}{ }^{+}$species were required to increase by approximately $1.5 \mathrm{log}$ units. Additionally, the $\mathrm{SiOPu}(\mathrm{OH})_{2}{ }^{+}$species could be assumed to account for the high sorption at low $\mathrm{pH}$. Although Figure 4.9 shows that the model over-predicted $\mathrm{Pu}$ sorption at high $\mathrm{pH}$, the surface complexation constants for $\mathrm{AlOPu}(\mathrm{OH})_{4}{ }^{-}$and $\mathrm{SiOPu}(\mathrm{OH})_{4}{ }^{-}$ species are relatively consistent for all models listed in Table 4.6.

There are a number of factors contributing to the under-prediction of $\mathrm{Pu}$ sorption at low $\mathrm{pH}$ and the over-prediction at high $\mathrm{pH}$. The high degree of $\mathrm{Pu}(\mathrm{IV})$ sorption at low $\mathrm{pH}$ is not expected based upon the observations from the $\mathrm{Pu}(\mathrm{IV})$-gibbsite and $\mathrm{Pu}(\mathrm{IV})$-silica datasets. As shown in Figure 3.4 (gibbsite) and Figure 3.6 (silica), at $\mathrm{pH}<5$ less than $90 \%$ of the $\mathrm{Pu}$ is sorbed after 62 days for both systems. For the $\mathrm{Pu}(\mathrm{IV})$-gibbsite system, less than $60 \%$ of the $\mathrm{Pu}$ is sorbed after 62 
days. The silica and gibbsite suspensions were estimated to have $3.85 \times 10^{-5} \mathrm{~mol} \mathrm{~L}^{-1}$ total surface sites while the montmorillonite suspensions were estimated to have $1.76 \times 10^{-6} \mathrm{~mol} \mathrm{~L}^{-1}$. Since the total number of surface sites in the montmorillonite suspensions are a factor of 30 lower than the silica and gibbsite suspensions, the sorption observed in the montmorillonite suspension cannot be attributed to equivalent reactions on gibbsite or silica. There are two very important assumptions in the above analysis that do not correctly describe the systems. They are:

1. $\mathrm{Pu}(\mathrm{IV})$ is the only $\mathrm{Pu}$ oxidation state in the system. While this was assumed for the gibbsite and silica systems, this was shown to be incorrect through chemical oxidation state analysis for all systems. In most cases, $\mathrm{Pu}(\mathrm{V})$ was the predominant aqueous oxidation state. There is also some evidence that $\mathrm{Pu}(\mathrm{IV})$ hydroxide polymer may have formed at high $\mathrm{pH}$ (see control samples Figure 3.1). By assuming $\mathrm{Pu}(\mathrm{IV}$ ) is the only oxidation state present in the silica and gibbsite suspensions, the $\mathrm{Pu}(\mathrm{IV})$ surface complexation constants are artificially lowered because they assume the aqueous $\mathrm{Pu}$ is $\mathrm{Pu}(\mathrm{IV})$ while it is actually $\mathrm{Pu}(\mathrm{V})$.

2. The only mechanism for sorption is surface complexation. This neglects ion exchange processes known to occur with montmorillonite clays, particularly at low $\mathrm{pH}$. Therefore, the increased sorption at low $\mathrm{pH}$ could very well be the result of ion exchange.

\section{SURFACE COMPLEXATION MODELING WITH INCORPORATION OF $\mathrm{Pu}(\mathrm{IV}) / \mathrm{Pu}(\mathrm{V}) \mathrm{REDOX}$ COUPLE}

\subsection{Incorporation of Active Pu(IV)/Pu(V) Redox Couple in Surface Complexation Model}

A revised conceptual model of $\mathrm{Pu}$ aqueous chemistry and sorption behavior can be devised from the following general observations of Pu solution chemistry and sorption behavior.

1. $\mathrm{Pu}(\mathrm{V} / \mathrm{VI}))$ is the predominant aqueous phase oxidation state even in the presence of minimal dissolved oxygen. This was demonstrated during $\mathrm{Pu}(\mathrm{OH})_{4}(\mathrm{~s})$ and $\mathrm{PuO}_{2}(\mathrm{~s})$ solubility experiments in which the aqueous phase oxidation state was measured (Neck et al., 2007; Rai, 1984; Rai et al., 2001; Rai et al., 1980)

2. Following sorption of $\mathrm{Pu}$ initially added as $\mathrm{Pu}(\mathrm{V})$, reduction to $\mathrm{Pu}(\mathrm{IV})$ progresses at various rates ranging from minutes to months. This has been shown using both indirect chemical separation oxidation state analysis techniques as well as direct x-ray absorption spectroscopy for the following solids:

- magnetite, $\mathrm{Fe}_{3} \mathrm{O}_{4}$ (Powell et al., 2003)

- goethite, $\alpha-\mathrm{FeOOH}$ (Keeney-Kennicutt and Morse, 1985; Penrose et al., 1987; Powell et al., 2005; Sanchez et al., 1985)

- hematite, $\alpha-\mathrm{Fe}_{2} \mathrm{O}_{3}$ (Keeney-Kennicutt and Morse, 1985; Powell et al., 2005)

- $\quad$ silica, $\mathrm{SiO}_{2}(\mathrm{Sanchez}, 1983)$ indirectly inferred

- gibbsite, $\alpha-\mathrm{Al}(\mathrm{OH})_{3}$ (Sanchez, 1983) indirectly inferred

- hausmannite, $\mathrm{Mn}_{3} \mathrm{O}_{4}$ and manganite, $\gamma$-MnOOH (Powell et al., 2003; Shaughnessey et al., 2003) 
- pyrolusite, $\beta-\mathrm{MnO}_{2}$ and ranceite (incorporated in Yucca Mountain tuff (Powell et al., 2006)

- $\quad$ sandy soils, (Kaplan et al., 2004)

3. Desorption of $\mathrm{Pu}(\mathrm{IV})$ appears to be coupled with reoxidation to $\mathrm{Pu}(\mathrm{V})$ at a rate approximately 5 orders of magnitude slower than the forward reduction rate. This yields a constant distribution of aqueous $\mathrm{Pu}(\mathrm{V})$ and sorbed $\mathrm{Pu}(\mathrm{IV})$ which appears to be significantly affected by $\mathrm{pH}$. This has been clearly demonstrated in Zavarin et al. ( 2008) with a series of batch flow-through experiments examining Pu sorption to goethite. Additionally, a similar difference in relative rates was required in a reactive transport model to predict the observed long-term Pu mobility (Kaplan et al., 2004).

4. Based upon preliminary results reported by Zavarin et al. (2008), ion exchange appears to significantly contribute to $\mathrm{Pu}(\mathrm{IV})$ sorption at low $\mathrm{pH}$ but has little contribution to $\mathrm{Pu}(\mathrm{V})$ sorption at intermediate and high ionic strengths.

A revised modeling scheme was developed based on the known Pu behavior. A flowsheet of the modeling scheme is shown in Figure 5.1. First, the surface complexation constants for $\mathrm{Pu}(\mathrm{V})$ are determined from the 24 hours sorption datasets for gibbsite and silica assuming $\mathrm{Pu}(\mathrm{V})$ is the predominant oxidation state. Note that inherent in this assumption is a further assumption that surface mediated reduction of $\mathrm{Pu}(\mathrm{V})$ to $\mathrm{Pu}(\mathrm{IV})$ is negligible within the first 24 hours. This step has already been performed as discussed above. The surface complexation constants are listed in Table 4.5.

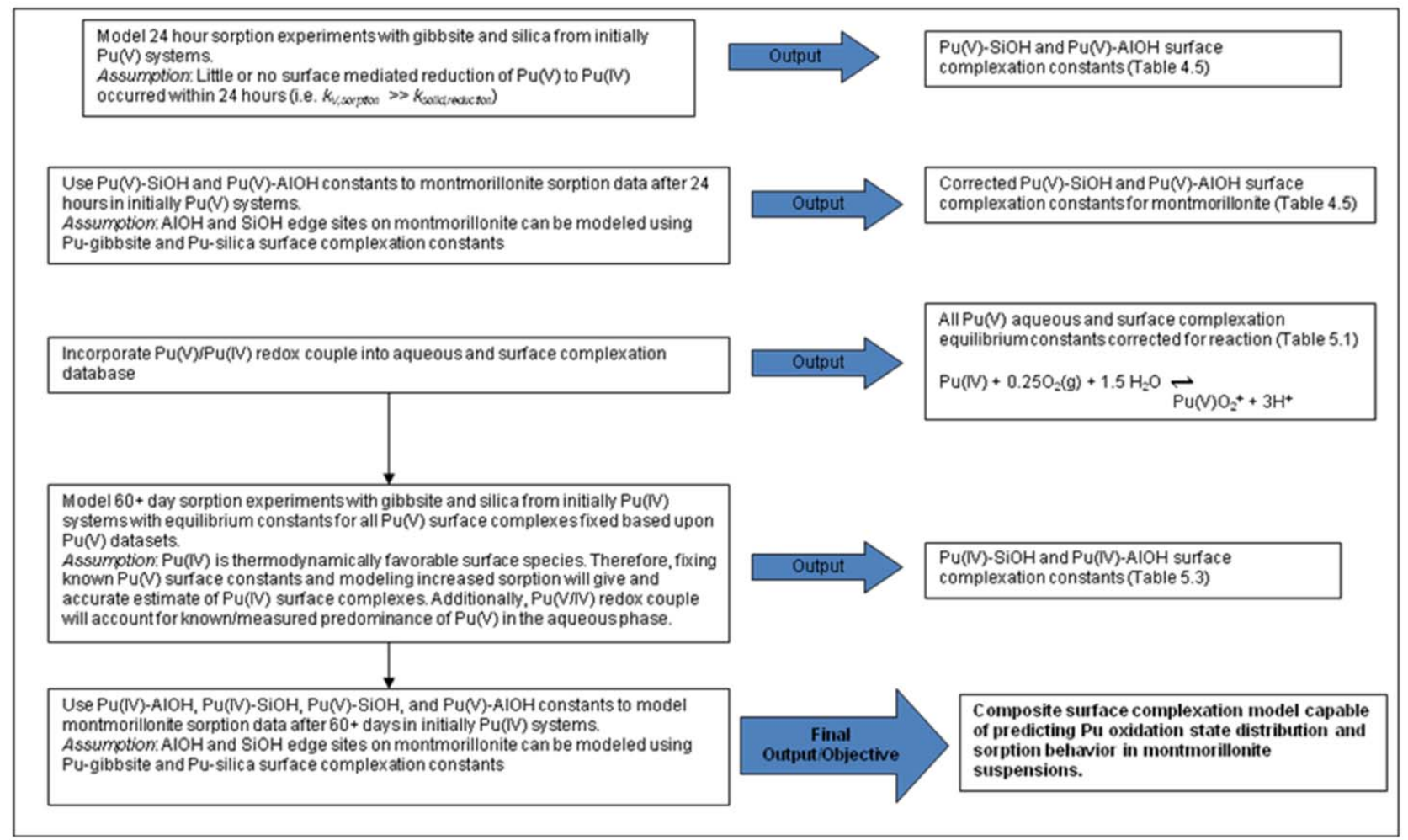

Figure 5.1: Flowsheet of revised surface complexation modeling approach. 
In the next step, the thermodynamic databases used in surface complexation modeling were rewritten such that the $\mathrm{Pu}(\mathrm{V}) / \mathrm{Pu}(\mathrm{IV})$ redox couple was considered. To accomplish this, the aqueous $\mathrm{Pu}(\mathrm{V})$ species were all rewritten in terms of the $\mathrm{Pu}(\mathrm{IV}) / \mathrm{Pu}(\mathrm{V})$ redox equation below:

$$
\mathrm{Pu}^{4+}+0.25 \mathrm{O}_{2}(\mathrm{~g})+1.5 \mathrm{H}_{2} \mathrm{O} \leftrightarrow \mathrm{PuO}_{2}^{+}+3 \mathrm{H}^{+} \log \mathrm{K}=3.439
$$

It is important to note that this modeling effort is limited in that only the $\mathrm{Pu}(\mathrm{IV} / \mathrm{V})$ redox couple is allowed and it is coupled with dissolved oxygen. This is necessary for simplicity in this preliminary modeling effort. However, further consideration of $\mathrm{Pu}$ chemistry including solubility, additional $\mathrm{Pu}$ oxidation states, and disproportionation reactions may be warranted. Table 5.1 below shows the revised $\log \mathrm{K}$ values used for aqueous species. Only the constants for $\mathrm{Pu}(\mathrm{V})$ species were changed from those presented in Table 4.1.

Table 5.1 Summary of Thermodynamic Constants for Aqueous Complexes in Current UGTA Database*

\begin{tabular}{|c|c|c|c|}
\hline Species & Reaction & $\begin{array}{c}\text { Ion Size } \\
\text { (A)** }\end{array}$ & $\begin{array}{r}\log \mathrm{K} \\
\left(25^{\circ} \mathrm{C}\right) \\
\end{array}$ \\
\hline \multicolumn{4}{|l|}{ Complexation } \\
\hline $\mathrm{OH}^{-}$ & $\mathrm{H}_{2} \mathrm{O} \leftrightarrow \mathrm{OH}^{-}+\mathrm{H}^{+}$ & 3.5 & -14 \\
\hline$\overline{\mathrm{CO}_{2}(\mathrm{aq})}$ & $\mathrm{H}++\mathrm{HCO}_{3}^{-} \leftrightarrow \mathrm{CO}_{2}(\mathrm{aq})$ & 3 & 6.34 \\
\hline $\mathrm{CO}_{3}^{--}$ & $\mathrm{HCO}_{3}^{-} \leftrightarrow \mathrm{H}++\mathrm{CO}_{3}^{--}$ & 4.5 & -10.33 \\
\hline $\mathrm{NaCl}(\mathrm{aq})$ & $\mathrm{Na}++\mathrm{Cl}^{-} \leftrightarrow \mathrm{NaCl}(\mathrm{aq})$ & 3 & -0.777 \\
\hline $\mathrm{NaCO}_{3}{ }^{-}$ & $\mathrm{Na}++\mathrm{HCO}_{3}^{-} \leftrightarrow \mathrm{H}^{+}+\mathrm{NaCO}_{3}^{-}$ & 4 & -9.814 \\
\hline $\mathrm{NaHCO}_{3}(\mathrm{aq})$ & $\mathrm{Na}++\mathrm{HCO}_{3}^{-} \leftrightarrow \mathrm{NaCO}_{3}^{-}$ & 3 & 0.154 \\
\hline $\mathrm{NaOH}(\mathrm{aq})$ & $\mathrm{Na}++\mathrm{H}_{2} \mathrm{O} \leftrightarrow \mathrm{NaOH}(\mathrm{aq})+\mathrm{H}^{+}$ & 3 & -14.205 \\
\hline $\mathrm{PuOH}^{+++}$ & $\mathrm{Pu}^{4+}+\mathrm{H}_{2} \mathrm{O} \leftrightarrow \mathrm{PuOH}^{+++}+\mathrm{H}^{+}$ & 5 & -0.78 \\
\hline $\mathrm{Pu}(\mathrm{OH})_{2}^{++}$ & $\mathrm{Pu}^{4+}+2 \mathrm{H}_{2} \mathrm{O} \leftrightarrow \mathrm{Pu}(\mathrm{OH})_{2}{ }^{++}+2 \mathrm{H}^{+}$ & 4.5 & -1.66 \\
\hline $\mathrm{Pu}(\mathrm{OH})_{3}^{+}$ & $\mathrm{Pu}^{4+}+3 \mathrm{H}_{2} \mathrm{O} \leftrightarrow \mathrm{Pu}(\mathrm{OH})_{3}^{+}+3 \mathrm{H}^{+}$ & 4 & -4.62 \\
\hline $\mathrm{Pu}(\mathrm{OH})_{4}(\mathrm{aq})$ & $\mathrm{Pu}^{4+}+4 \mathrm{H}_{2} \mathrm{O} \leftrightarrow \mathrm{Pu}(\mathrm{OH})_{4}(\mathrm{aq})+4 \mathrm{H}^{+}$ & 3 & -8.85 \\
\hline $\mathrm{Pu}(\mathrm{OH})_{2}\left(\mathrm{CO}_{3}\right)_{2}^{--}$ & $\mathrm{Pu}^{4+}+2 \mathrm{H}_{2} \mathrm{O}+2 \mathrm{HCO}_{3}^{-} \leftrightarrow \mathrm{Pu}(\mathrm{OH})_{2}\left(\mathrm{CO}_{3}\right)^{2--}+4 \mathrm{H}^{+}$ & 4 & -2.75 \\
\hline $\mathrm{Pu}(\mathrm{OH})_{4}\left(\mathrm{CO}_{3}\right)_{2}$ & $\mathrm{Pu}^{4+}+4 \mathrm{H}_{2} \mathrm{O}+2 \mathrm{HCO}_{3}^{-} \leftrightarrow \mathrm{Pu}(\mathrm{OH})_{4}\left(\mathrm{CO}_{3}\right)^{2--}+6 \mathrm{H}^{+}$ & 5 & -25.53 \\
\hline $\mathrm{Pu}\left(\mathrm{CO}_{3}\right)_{4}^{----}$ & $\mathrm{Pu}^{4+}+4 \mathrm{HCO}_{3}^{-} \leftrightarrow \mathrm{Pu}\left(\mathrm{CO}_{3}\right)_{4}^{4-}+4 \mathrm{H}^{+}$ & 5 & -4.62 \\
\hline $\mathrm{Pu}\left(\mathrm{CO}_{3}\right)_{5}{ }^{6-}$ & $\mathrm{Pu}^{4+}+5 \mathrm{HCO}_{3}^{-} \leftrightarrow \mathrm{Pu}\left(\mathrm{CO}_{3}\right)_{5}^{6-}+5 \mathrm{H}^{+}$ & 5 & -16.3 \\
\hline $\mathrm{PuO}_{2} \mathrm{OH}(\mathrm{aq})$ & $\mathrm{Pu}^{4+}+0.25 \mathrm{O}_{2}(\mathrm{~g})+2.5 \mathrm{H}_{2} \mathrm{O} \leftrightarrow \mathrm{PuO}_{2} \mathrm{OH}(\mathrm{aq})+4 \mathrm{H}^{+}$ & 3 & -6.261 \\
\hline $\mathrm{PuO}_{2} \mathrm{CO}_{3}^{-}$ & $\mathrm{Pu}^{4+}+0.25 \mathrm{O}_{2}(\mathrm{~g})+1.5 \mathrm{H}_{2} \mathrm{O}+\mathrm{HCO}_{3}^{-} \leftrightarrow \mathrm{PuO}_{2} \mathrm{CO}_{3}^{-}+4 \mathrm{H}^{+}$ & 4 & -1.771 \\
\hline $\mathrm{PuO}_{2}\left(\mathrm{CO}_{3}\right)_{2}^{---}$ & $\mathrm{Pu}^{4+}+0.25 \mathrm{O}_{2}(\mathrm{~g})+1.5 \mathrm{H}_{2} \mathrm{O}+2 \mathrm{HCO}_{3}^{-} \leftrightarrow \mathrm{PuO}_{2}\left(\mathrm{CO}_{3}\right)_{2}^{3-}+5 \mathrm{H}^{+}$ & 4 & -10.681 \\
\hline $\mathrm{PuO}_{2}\left(\mathrm{CO}_{3}\right)_{3}{ }^{5-}$ & $\mathrm{Pu}^{4+}+0.25 \mathrm{O}_{2}(\mathrm{~g})+1.5 \mathrm{H}_{2} \mathrm{O}+3 \mathrm{HCO}_{3}{ }^{-} \leftrightarrow \mathrm{PuO}_{2}\left(\mathrm{CO}_{3}\right)_{3}{ }^{5-}+6 \mathrm{H}^{+}$ & 5 & -22.561 \\
\hline \multicolumn{4}{|l|}{$\overline{R e d o x}$} \\
\hline $\mathrm{PuO}_{2}^{+} / \mathrm{Pu}^{++++}$ & $\mathrm{Pu}^{++++}+0.25 \mathrm{O}_{2}(\mathrm{~g})+1.5 \mathrm{H}_{2} \mathrm{O} \leftrightarrow \mathrm{PuO}_{2}^{+}+3 \mathrm{H}^{+}$ & 4 & 3.439 \\
\hline
\end{tabular}

*Constants predominantly taken from DATACOM.V8.R6 of the GEMBOCHS thermodynamic database (Turner et al., 1998) and associated revisions (Carle et al., 2006; Pawloski et al., 2000; Pawloski et al., 2001; Tompson et al., 1999).

The solid phase thermodynamic database was similarly changed to incorporate the $\mathrm{Pu}(\mathrm{V}) / \mathrm{Pu}(\mathrm{IV}$ redox couple. $\mathrm{The} \mathrm{Pu}(\mathrm{V})$ surface complexation constants from the silica and gibbsite experiments listed in Table 4.5 were rewritten as shown in Table 5.2. 
Table 5.2: $\mathrm{Pu}(\mathrm{V})$-aluminol and $\mathrm{Pu}(\mathrm{V})$-silanol Surface Complexation Constants Written in Terms of the $\mathrm{Pu}(\mathrm{V}) / \mathrm{Pu}(\mathrm{IV}) \mathrm{Redox}$ Couple.

\begin{tabular}{llc}
\hline Species & Reaction & $\log \mathrm{K}$ \\
\hline $\mathrm{SiOHPuO}_{2}{ }^{+}$ & $\mathrm{SiOH}+\mathrm{Pu}^{4+}+0.25 \mathrm{O}_{2}(\mathrm{~g})+1.5 \mathrm{H}_{2} \mathrm{O} \leftrightarrow \mathrm{SiOHPuO}_{2}{ }^{+}+3 \mathrm{H}^{+}$ & 7.549 \\
$\mathrm{SiOPuO}_{2}{ }^{\mathrm{O}}$ & $\mathrm{SiOH}+\mathrm{Pu}^{4+}+0.25 \mathrm{O}_{2}(\mathrm{~g})+1.5 \mathrm{H}_{2} \mathrm{O} \leftrightarrow \mathrm{SiOPuO}_{2}{ }^{\circ}+4 \mathrm{H}^{+}$ & 2.339 \\
$\mathrm{SiOPuO}_{2} \mathrm{OH}^{-}$ & $\mathrm{SiOH}+\mathrm{Pu}^{4+}+0.25 \mathrm{O}_{2}(\mathrm{~g})+2.5 \mathrm{H}_{2} \mathrm{O} \leftrightarrow \mathrm{SiOPuO}_{2} \mathrm{OH}^{-}+5 \mathrm{H}^{+}$ & -7.861 \\
& & \\
$\mathrm{AlOHPuO}_{2}{ }^{+}$ & $\mathrm{AlOH}+\mathrm{Pu}^{4+}+0.25 \mathrm{O}_{2}(\mathrm{~g})+1.5 \mathrm{H}_{2} \mathrm{O} \leftrightarrow \mathrm{AlOHPuO}_{2}{ }^{+}+3 \mathrm{H}^{+}$ & 8.799 \\
$\mathrm{AlOPuO}_{2}{ }^{+}$ & $\mathrm{AlOH}+\mathrm{Pu}^{4+}+0.25 \mathrm{O}_{2}(\mathrm{~g})+1.5 \mathrm{H}_{2} \mathrm{O} \leftrightarrow \mathrm{AlOPuO}_{2}{ }^{\circ}+4 \mathrm{H}^{+}$ & 0.349 \\
$\mathrm{AlOPuO}_{2} \mathrm{OH}^{-}$ & $\mathrm{AlOH}+\mathrm{Pu}^{4+}+0.25 \mathrm{O}_{2}(\mathrm{~g})+2.5 \mathrm{H} 2 \mathrm{O} \leftrightarrow \mathrm{AlOPuO}_{2} \mathrm{OH}^{-}+5 \mathrm{H}^{+}$ & -8.161 \\
\hline
\end{tabular}

As written in Equation 5.1, the $\mathrm{Pu}(\mathrm{V}) / \mathrm{Pu}(\mathrm{IV})$ redox couple is dependent on $\mathrm{O}_{2}$ (g) fugacity. As a result, the surface complexation constants will be dependent on the input $\mathrm{O}_{2}(\mathrm{~g})$ fugacity. It is possible to estimate the $\mathrm{O}_{2}(\mathrm{~g})$ fugacity from redox measurements. Unfortunately, redox measurements were not made for all samples at the time of sampling. Therefore, an empirical equation was fit to the known measurements to estimate the $\mathrm{O}_{2}(\mathrm{~g})$ fugacity for all samples to be used in modeling efforts. Figure 5.2 shows the measured redox potentials versus the $\mathrm{pH}$ of each suspension. Although there is a considerable amount of scatter in the data, there is a clear trend that can be fit to a linear model.

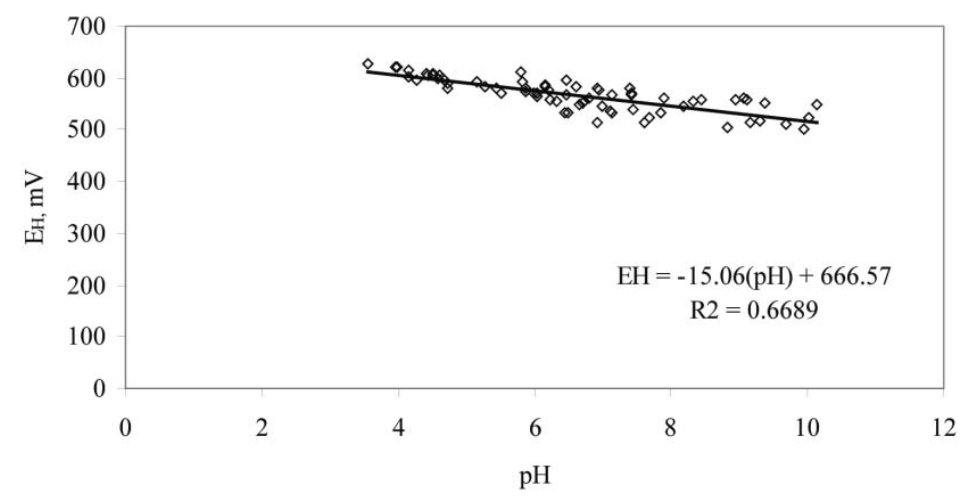

Figure 5.2: Measured redox potential versus suspension $\mathrm{pH}$ from samples in Pu sorption experiments.

Using that empirical equation, the $\mathrm{E}_{\mathrm{H}}$ of each sample was calculated based upon the measured solution $\mathrm{pH}$. Then the $\mathrm{O}_{2}(\mathrm{~g})$ fugacity was calculated from the $\mathrm{E}_{\mathrm{H}}$ value using the two relationships:

$$
\begin{aligned}
& \mathrm{O}_{2}(\mathrm{~g})+4 \mathrm{H}++4 e^{-} \Leftrightarrow 2 \mathrm{H}_{2} \mathrm{O} \quad \log \mathrm{K}=20.78 \\
& \mathrm{E}_{\mathrm{H}}=59.16 \mathrm{p} e^{-}
\end{aligned}
$$

The $\log \mathrm{O}_{2}(\mathrm{~g})$ fugacity for each sample was calculated from the sample $\mathrm{pH}$ at the time of measurement by combining Equations 5.2 and 5.3 to obtain Equation 5.4: 


$$
\log \mathrm{O}_{2}(\mathrm{~g})=-20.78+\mathrm{pH}+0.25 *\left(\mathrm{E}_{\mathrm{H}} / 59.16\right)
$$

The $\mathrm{E}_{\mathrm{H}}$ value in Equation 5.4 was calculated using the empirical relationship determined from the data in Figure 5.2.

$$
\mathrm{E}_{\mathrm{H}}=-15.06 * \mathrm{pH}+666.57
$$

This calculation yielded $\log \mathrm{O}_{2}(\mathrm{~g})$ values ranging from -15 to -8 . While these values are considered oxidizing, estimations of $\log \mathrm{O}_{2}(\mathrm{~g})$ fugacity do not reflect the molar concentration of dissolved oxygen. This is important to consider as Equation 5.1 indicates a 0.25 order dependence of $\mathrm{O}_{2}(\mathrm{~g})$ on the $\mathrm{Pu}(\mathrm{IV} / \mathrm{V})$ couple. Therefore the high $\mathrm{O}_{2}(\mathrm{~g})$ fugacities are more realistic when considering the dissolved oxygen concentration. To independently test this approach, some Pu solubility measurements of Rai et al. (2001) were modeled. Rai et al. (2001) reported total dissolved $\mathrm{Pu}$ in equilibrium with hydrous plutonium oxide as well as the distribution of the aqueous oxidation states. A model was developed with the total dissolved $\mathrm{Pu}$ concentration, $\mathrm{pH}$, and estimated $\log \mathrm{O}_{2}(\mathrm{~g})$ concentration (Figure 5.2). Using this approach of estimating the $\log \mathrm{O}_{2}(\mathrm{~g})$ fugacity, a reasonable fit to the data reported by Rai et al. (2001) was achieve as shown in Figure 5.3.

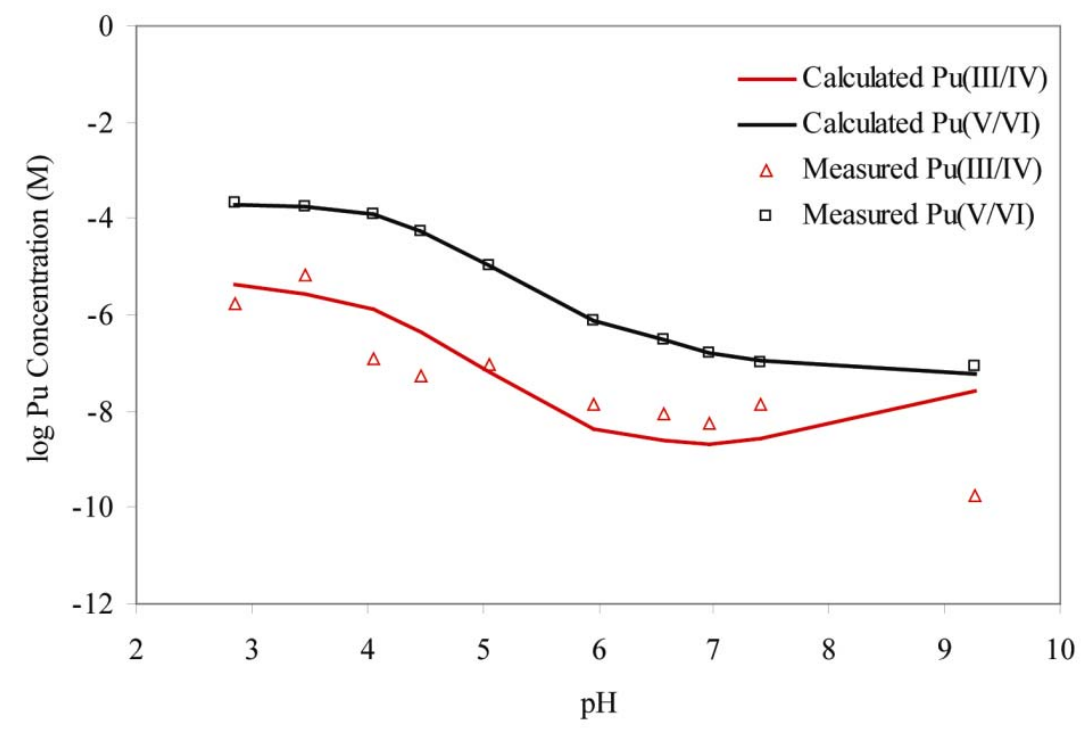

Figure 5.3: Fit of Pu solution species to solubility data of (Rai et al., 2001) assuming $\log \mathrm{O}_{2}(\mathrm{~g})$ fugacity calculated from Equation 5.4.

\subsection{Refinement of Model with Active Pu(IV)/Pu(V) Redox Couple}

Using the revised constants shown in Tables 5.1 and 5.2, the Pu(IV)-aluminol and $\mathrm{Pu}(\mathrm{IV})$-silanol surface complexation constants were refitted. Data from the initially $\mathrm{Pu}(\mathrm{IV})$ sorption experiments with silica and gibbsite after 62 days were used in the model because they are assumed to 
represent the equilibrium distribution between $\mathrm{Pu}(\mathrm{IV})$ and $\mathrm{Pu}(\mathrm{V})$ in each system. One unfortunate results of using these datasets was that the effect of carbonate must also be incorporated in the model. As discussed above the carbonate concentrations that were used in the model were input based upon the initial amounts of carbonate added to each sample. However, additional carbonate was added to each sample through addition of $\mathrm{NaOH}$ during $\mathrm{pH}$ adjustments and through diffusion of $\mathrm{CO}_{2}(\mathrm{~g})$ through the vial walls. Therefore, the input carbonate concentration should be assumed to have at least a $10 \%$ uncertainty. This uncertainty must be carried over to the surface complexation constants as they are indirectly dependent on the total carbonate concentration. The carbonate concentrations used in the model input along with other system parameters (Total $\mathrm{Pu}$ concentration, Sorbed $\mathrm{Pu}$ concentration, and $\mathrm{pH}$ ) are listed for each dataset in Appendix C.

The data and model fit describing $\mathrm{Pu}(\mathrm{IV})$ sorption to silica after 62 days is shown in Figure 5.4. The model closely predicted the measured sorbed concentration. The $\mathrm{Pu}(\mathrm{IV})$ surface complexes are shown in red and the $\mathrm{Pu}(\mathrm{V})$ surface complexes are shown in blue. Consistent with the expected behavior of sorbed $\mathrm{Pu}$, the model predicted that the majority of sorbed $\mathrm{Pu}$ will be $\mathrm{Pu}(\mathrm{IV})$. Furthermore, $\mathrm{Pu}(\mathrm{V})$ was correctly predicted to be the dominant aqueous phase oxidation state $\left(\right.$ as $\mathrm{PuO}_{2}{ }^{+}(\mathrm{aq})$ and $\left.\mathrm{PuO}_{2} \mathrm{CO}_{3}{ }^{-}(\mathrm{aq})\right)$. Therefore, in addition to accurately predicting the aqueous and solid phase $\mathrm{Pu}$ concentrations, the revised surface complexation model was able to closely predict the expected oxidation state distribution of $\mathrm{Pu}$ in the system where the solid phase was dominated by $\mathrm{Pu}(\mathrm{IV})$ and the aqueous phase was dominated by $\mathrm{Pu}(\mathrm{V})$. The revised nonelectrostatic surface complexation constants are shown in Table 5.3. In order to predict the appearance of solid phase $\mathrm{Pu}(\mathrm{IV})$ in the presence of $\mathrm{O}_{2}(\mathrm{~g})$, the constants for both of the assumed $\mathrm{Pu}(\mathrm{IV})$-silanol species increased. The $\log \mathrm{K}$ values for $\mathrm{SiOPu}(\mathrm{OH})_{3}$ increased from -3.55 to 0.14 and the value for $\mathrm{SiOPu}(\mathrm{OH})_{4}{ }^{-}$increased from -9.10 to -7.58 . These values are consistent with the presumed thermodynamic favorability of sorbed $\mathrm{Pu}(\mathrm{IV})$ complexes.

Similar behavior was observed for the Pu-gibbsite sorption dataset and model (Figure 5.5). After incorporation of the $\mathrm{Pu}(\mathrm{IV} / \mathrm{V})$ redox couple, the model accurately predicted both the solid and aqueous phase $\mathrm{Pu}$ concentrations. Additionally, the oxidation state of sorbed $\mathrm{Pu}$ was dominated by $\mathrm{Pu}(\mathrm{IV})$ except for the high $\mathrm{pH}$ region, where a significant fraction of sorbed $\mathrm{Pu}$ was predicted to be the $\mathrm{AlOPuO}_{2} \mathrm{OH}^{-}$surface species. Similar to the silica model discussed above, the aqueous phase $\mathrm{Pu}$ was predominantly $\mathrm{Pu}(\mathrm{V})$ as $\mathrm{PuO}_{2}{ }^{+}$and $\mathrm{PuO}_{2} \mathrm{CO}_{3}{ }^{-}$.

In order to achieve the fit shown in Figure 5.5, the predicted surface speciation had to be changed. Without coupling $\mathrm{Pu}(\mathrm{IV} / \mathrm{V})$, the best fit to the available data was found using $\equiv \mathrm{AlOPu}(\mathrm{OH})_{2}{ }^{+}, \equiv \mathrm{AlOPu}(\mathrm{OH})_{3}$, and $\equiv \mathrm{AlOPu}(\mathrm{OH})_{4}{ }^{-}$species. The $\equiv \mathrm{AlOPu}(\mathrm{OH})_{4}{ }^{-}$species was not required when coupling $\mathrm{Pu}(\mathrm{IV} / \mathrm{V})$ but a less hydrolyzed $\equiv \mathrm{AlOPu}(\mathrm{OH})^{++}$species was required to fit the low $\mathrm{pH}$ data. While developing the uncoupled model, it was found that the $\equiv \mathrm{AlOPu}(\mathrm{OH})^{++}$ species could be included and a slightly better fit could be obtained. However, the increase in model complexity (addition of a fourth surface species) was not justified for the slightly better fit. Similar to the $\mathrm{Pu}(\mathrm{IV})$-silanol constants, the $\log \mathrm{K}$ values for $\mathrm{Pu}(\mathrm{IV})$-aluminol constants increased when adding the $\mathrm{Pu}(\mathrm{IV} / \mathrm{V})$ couple. The $\log \mathrm{K}$ value for $\equiv \mathrm{AlOPu}(\mathrm{OH})_{2}{ }^{+}$increased from 5.10 to 7.34 and the value for $\equiv \mathrm{AlOPu}(\mathrm{OH})_{3}$ increased from -2.64 to -0.10 . 

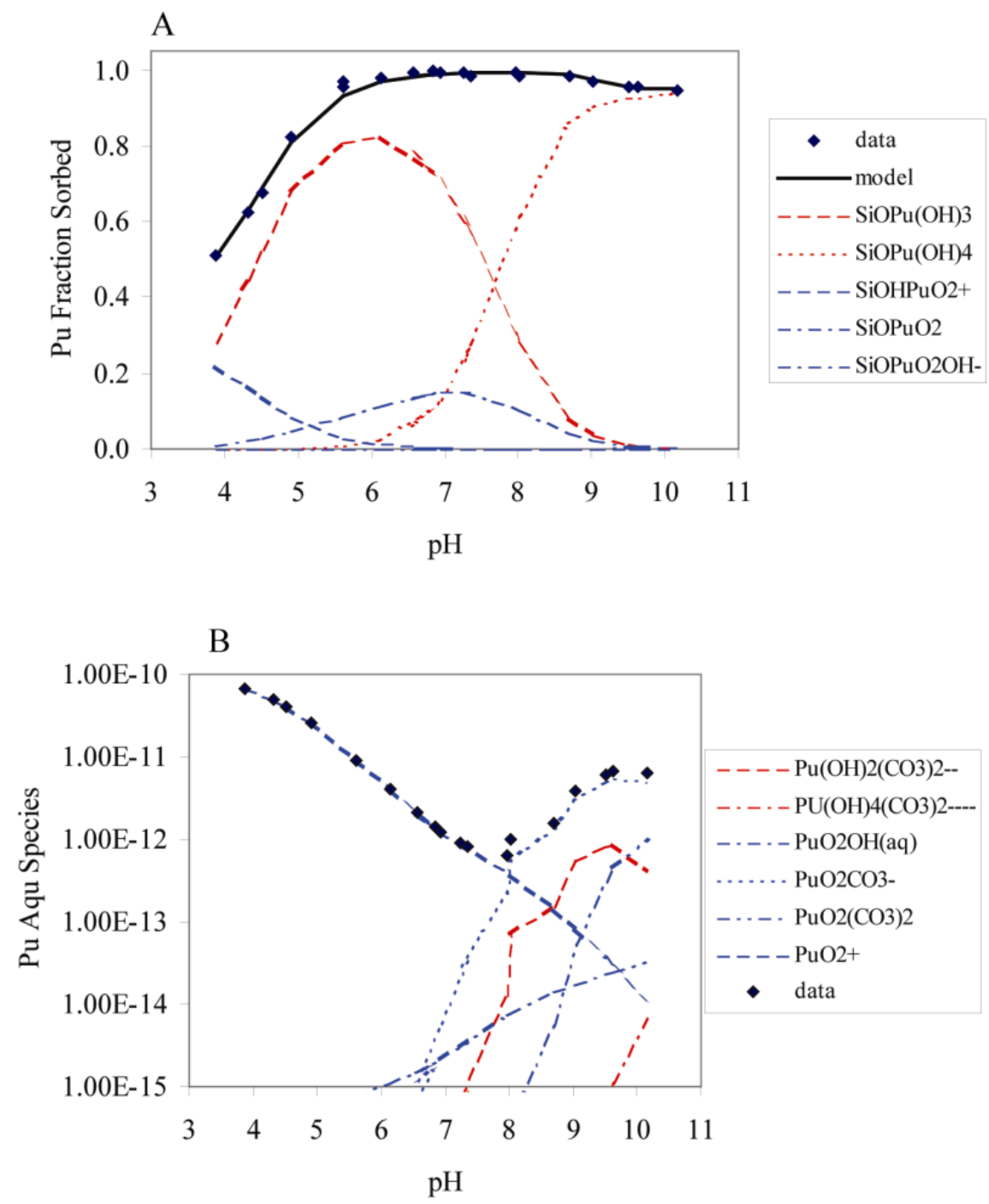

Figure 5.4 Model Prediction of $\mathrm{Pu}$ (a) solid phase and (b) aqueous phase distribution in silica suspension after 62 days with carbonate present. Revised SCM constants listed in Table 5.3 used to obtain fit. 

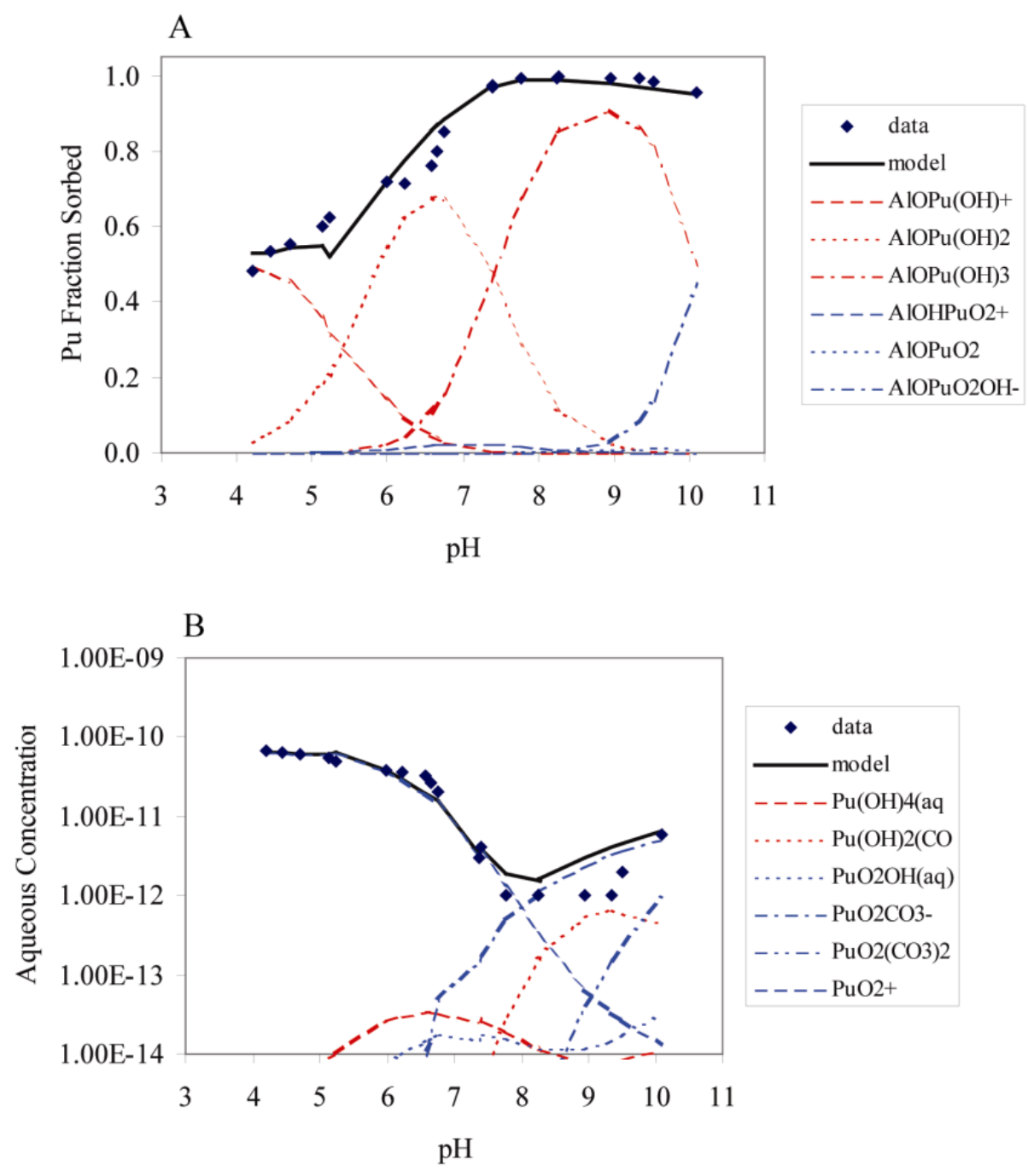

Figure 5.5 Model Prediction of $\mathrm{Pu}$ (a) solid phase and (b) aqueous phase distribution in silica suspension after 62 days with carbonate present. Revised SCM constants listed in Table 5.3 used to obtain fit. 
Table 5.3: Revised Pu-aluminol and Pu-silanol Surface Complexation Constants written in terms of the $\mathrm{Pu}(\mathrm{V}) / \mathrm{Pu}(\mathrm{IV})$ redox couple.

\begin{tabular}{|c|c|c|}
\hline Species & Reaction & $\log \mathrm{K}$ \\
\hline$\overline{\mathrm{SiOHPuO}}{ }_{2}^{+}$ & $\overline{\mathrm{SiOH}}+\mathrm{Pu}^{4+}+0.25 \mathrm{O}_{2}(\mathrm{~g})+1.5 \mathrm{H}_{2} \mathrm{O} \leftrightarrow \mathrm{SiOHPuO}_{2}^{+}+3 \mathrm{H}^{+}$ & 7.55 \\
\hline $\mathrm{SiOPuO}_{2}{ }^{\mathrm{o}}$ & $\mathrm{SiOH}+\mathrm{Pu}^{4+}+0.25 \mathrm{O}_{2}(\mathrm{~g})+1.5 \mathrm{H}_{2} \mathrm{O} \leftrightarrow \mathrm{SiOPuO}_{2}{ }^{2}+4 \mathrm{H}^{+}$ & 2.34 \\
\hline $\mathrm{SiOPuO}_{2} \mathrm{OH}^{-}$ & $\mathrm{SiOH}+\mathrm{Pu}^{4+}+0.25 \mathrm{O}_{2}(\mathrm{~g})+2.5 \mathrm{H}_{2} \mathrm{O} \leftrightarrow \mathrm{SiOPuO}_{2} \mathrm{OH}^{-}+5 \mathrm{H}^{+}$ & -7.86 \\
\hline $\mathrm{AlOHPuO}_{2}^{+}$ & $\mathrm{AlOH}+\mathrm{Pu}^{4+}+0.25 \mathrm{O}_{2}(\mathrm{~g})+1.5 \mathrm{H}_{2} \mathrm{O} \leftrightarrow \mathrm{AlOHPuO}_{2}^{+}+3 \mathrm{H}^{+}$ & 8.80 \\
\hline $\mathrm{AlOPuO}_{2}{ }^{\mathrm{o}}$ & $\mathrm{AlOH}+\mathrm{Pu}^{4+}+0.25 \mathrm{O}_{2}(\mathrm{~g})+1.5 \mathrm{H}_{2} \mathrm{O} \leftrightarrow \mathrm{AlOPuO}_{2}{ }^{\circ}+4 \mathrm{H}^{+}$ & 0.35 \\
\hline $\mathrm{AlOPuO}_{2} \mathrm{OH}^{-}$ & $\mathrm{AlOH}+\mathrm{Pu}^{4+}+0.25 \mathrm{O}_{2}(\mathrm{~g})+2.5 \mathrm{H} 2 \mathrm{O} \leftrightarrow \mathrm{AlOPuO}_{2} \mathrm{OH}^{-}+5 \mathrm{H}^{+}$ & -8.16 \\
\hline $\mathrm{AlOPu}(\mathrm{OH})^{++}$ & $\mathrm{AlOH}+\mathrm{Pu}^{4+}+\mathrm{H}_{2} \mathrm{O} \leftrightarrow \mathrm{AlOPu}(\mathrm{OH})^{++}+2 \mathrm{H}^{+}$ & 12.82 \\
\hline $\mathrm{AlOPu}(\mathrm{OH})_{2}^{+}$ & $\mathrm{AlOH}+\mathrm{Pu}^{4+}+2 \mathrm{H}_{2} \mathrm{O} \leftrightarrow \mathrm{AlOPu}(\mathrm{OH})_{2}{ }^{+}+4 \mathrm{H}^{+}$ & 7.34 \\
\hline $\mathrm{AlOPu}(\mathrm{OH})_{3}{ }^{\mathrm{o}}$ & $\mathrm{AlOH}+\mathrm{Pu}^{4+}+3 \mathrm{H}_{2} \mathrm{O} \leftrightarrow \mathrm{AlOPu}(\mathrm{OH})_{3}{ }^{0}+4 \mathrm{H}^{+}$ & -0.10 \\
\hline $\mathrm{SiOPu}(\mathrm{OH})_{3}{ }^{\circ}$ & $\mathrm{SiOH}+\mathrm{Pu}^{4+}+3 \mathrm{H}_{2} \mathrm{O} \leftrightarrow \mathrm{SiOPu}(\mathrm{OH})_{3}{ }^{0}+4 \mathrm{H}^{+}$ & 0.14 \\
\hline $\mathrm{SiOPu}(\mathrm{OH})_{4}^{-}-$ & $\mathrm{SiOH}+\mathrm{Pu}^{4+}+4 \mathrm{H}_{2} \mathrm{O} \leftrightarrow \mathrm{SiOPu}(\mathrm{OH})_{4}^{-}+5 \mathrm{H}^{+}$ & -7.58 \\
\hline
\end{tabular}

\subsection{Modeling Pu Sorption to Montmorillonite with Active Pu(IV)/Pu(V) Redox Couple}

Since the experiments in montmorillonite systems which were initially $\mathrm{Pu}(\mathrm{V})$ did not appear to reach a steady-state within the time of these experiments (Figure 3.10b), only the initially $\mathrm{Pu}(\mathrm{IV}$ ) dataset was used for this modeling comparison. Using the surface complexation constants listed in Table 5.3 and the thermodynamic constants listed in Table 5.1 (including the $\mathrm{Pu}(\mathrm{IV} / \mathrm{V})$ redox couple, sorption of $\mathrm{Pu}(\mathrm{IV})$ to montmorillonite was predicted. The model output is shown in Figure 5.6 below and plotted with the initially $\mathrm{Pu}(\mathrm{IV})$-montmorillonite dataset obtained after 62 days under $\mathrm{CO}_{2}(\mathrm{~g})$ equilibrated conditions. The model does an acceptable job of fitting the data at high $\mathrm{pH}$ values. As discussed above, the difficultly of predicting $\mathrm{Pu}(\mathrm{IV})$ sorption in the presence of carbonate and the uncertainty in the exact carbonate concentrations are believed to be responsible for the poor fit at the highest $\mathrm{pH}$ values. Of greater concern is the very poor fit observed at low $\mathrm{pH}$. The most significant predicted sorbing species is $\equiv \operatorname{SiOPu}(\mathrm{OH})_{3}$ but the predicted sorbed concentration is significantly lower than the observed concentration.

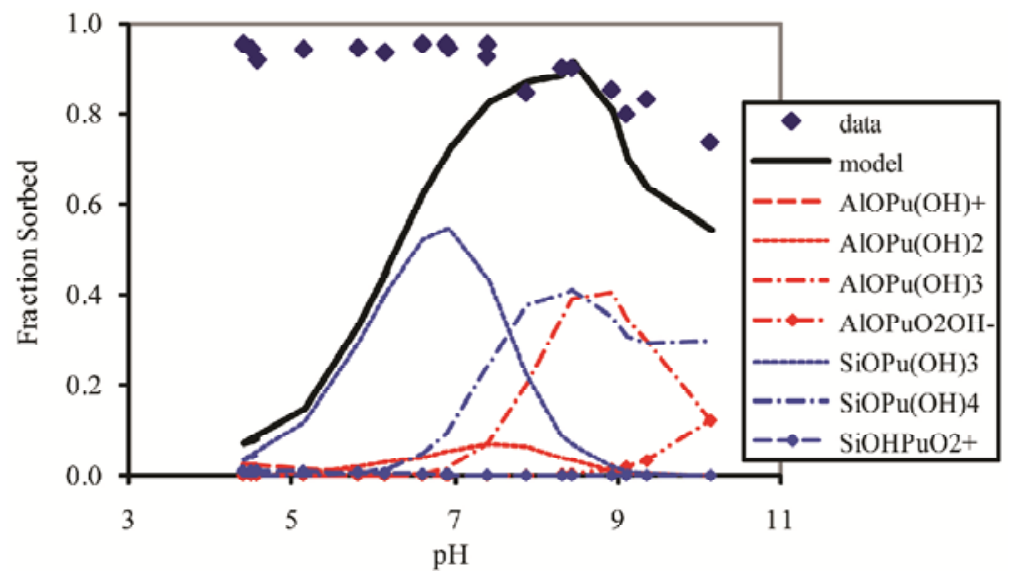

Figure 5.6 Model prediction of Pu sorption to montmorillonite after 62 days with carbonate present. Pu surface complexation constants fixed from Pu-silanol and Pu-aluminol species as listed in Table 5.3. 
An examination of estimated surface site concentrations for each mineral and the sorption behavior at steady-state (Figrue 5.7) for Pu(IV) systems in gibbsite, silica, and montmorillonite suspensions provides some insight regarding the poor montmorillonite fit at low $\mathrm{pH}$. There are two possible explanations for the observed behavior and apparent inconsistency in the model:

1. Sorption of Pu to montmorillonite is occurring by a process other than compelxation with aluminol and silanol groups

2. The assumption that $\equiv \mathrm{SiOH}$ and $\equiv \mathrm{AlOH}$ sites make up $10 \%$ of the available surface area is incorrect

It is highly unlikely that the montmorillonite edge sites which make the majority of $\equiv \mathrm{SiOH}$ and $\equiv \mathrm{AlOH}$ site account for exactly $10 \%$ of the measured surface area as is assumed in the model. However, even if $100 \%$ of the measured surface area was assumed to be $\equiv \mathrm{SiOH}$ and $\equiv \mathrm{AlOH}$ groups, the total surface site concentration $\left(1.8 \times 10^{-5} \mathrm{M}\right)$ is still $2 \times$ less than the assumed surface site concentration in the silica and gibbsite suspensions. Therefore, it is likely that another process is controlling Pu sorption to montmorillonite at low $\mathrm{pH}$. The most likely mechanism is ion exchange.

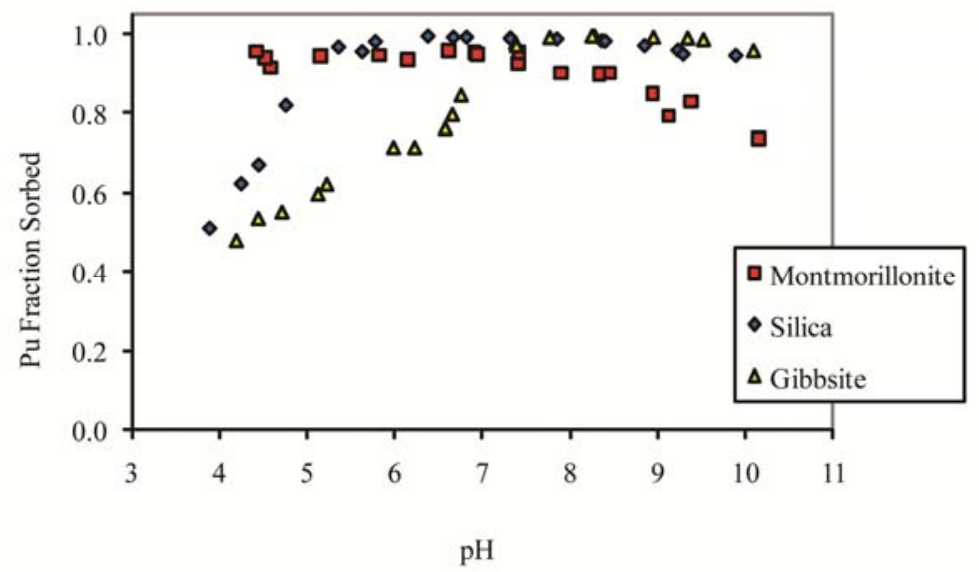

Figure 5.7: Measured Pu sorption at steady-state in gibbsite, silica, and montmorillonite suspensions from initially $\mathrm{Pu}(\mathrm{IV}), \mathrm{CO}_{2}(\mathrm{~g})$ equilibrated solutions.

Using the Vaneslow model for ion exchange (Sposito, 1977), exchange reactions of $\mathrm{Pu}^{4+}$ were modeled relative to $\mathrm{Na}^{+}$(Equations 5.6 and 5.7). The cation exchange capacity of $76.4 \mathrm{meq} / 100 \mathrm{~g}$ reported for the SWy-1 montmorillonite by the Clay Minerals Society (Appendix A) was used to calculate an ion exchange site concentration of $1.3 \times 10^{-4} \mathrm{M}$. This exchange site concentration and the surface complexation constants for Pu-aluminol and $\mathrm{Pu}$-silanol groups listed in Table 5.3 were held constant during the modeling exercise. It appears that a steady state $\mathrm{Pu}$ distribution was achieved after approximately 24 hours. Therefore, the 24 hours and 62 day sorption dataset from initially $\mathrm{Pu}(\mathrm{IV})$ systems in the presence of $\mathrm{CO}_{2}(\mathrm{~g})$ were used to determine the ion exchange constant. 


$$
\begin{array}{ll}
\mathrm{X}^{-}+\mathrm{Pu}^{4+}+3 \mathrm{H}_{2} 0 \rightarrow \mathrm{X}^{-} \mathrm{Pu}(\mathrm{OH})_{3}{ }^{+}+3 \mathrm{H}^{+} & \log \mathrm{K}=-1.45 \\
\mathrm{X}^{-}+\mathrm{Na}^{+} \rightarrow \mathrm{XNa}^{-} \mathrm{Na}^{+} & \log \mathrm{K}=0
\end{array}
$$

The best fit was obtained by assuming exchange with $\mathrm{Pu}(\mathrm{OH})_{3}{ }^{+}$(Equation 5.8 and Figure 5.8). To calculate the direct exchange constant, the $\mathrm{Pu}^{4+}$ hydrolysis reaction was subtracted out as follows:

$$
\begin{aligned}
& \mathrm{Pu}(\mathrm{OH})_{3}{ }^{+}+3 \mathrm{H}^{+} \rightarrow \mathrm{Pu}^{4+}+3 \mathrm{H}_{2} \mathrm{O} \log \mathrm{K}=4.62 \\
& \frac{+\mathrm{XNa}^{+}+\mathrm{Pu}^{4+}+3 \mathrm{H}_{2} 0 \rightarrow \mathrm{X}^{-} \mathrm{Pu}(\mathrm{OH})_{3}^{+}+\mathrm{Na}^{+}+3 \mathrm{H}^{+} \log \mathrm{K}=-1.45}{\mathrm{X}^{-} \mathrm{Na}^{+}+\mathrm{Pu}(\mathrm{OH})_{3}{ }^{+} \rightarrow \mathrm{X}^{-} \mathrm{Pu}(\mathrm{OH})_{3}{ }^{+}+\mathrm{Na}^{+} \log \mathrm{K}=3.17}
\end{aligned}
$$

The high exchange constant (3.17) is indicative of a strong affinity of $\mathrm{Pu}$ for montmorillonite basal plane ion-exchange sites. Similar high values have been reported for Cs, which is known to have strong ion exchange interaction with this mineral. There is insufficient experimental data in this dataset to confirm that ion exchange is occurring. The discussion of the surface site density provides only circumstantial evidence to justify incorporation of ion exchange into this model. However, evidence of $\mathrm{Pu}$ ion exchange on SWy-1 montmorillonite was recently reported (Zavarin et al., 2008). The slight increase in Pu sorption at low $\mathrm{pH}$ values (Figure 3.10) is also indicative of $\mathrm{Pu}(\mathrm{V})$ reduction followed by ion exchange.

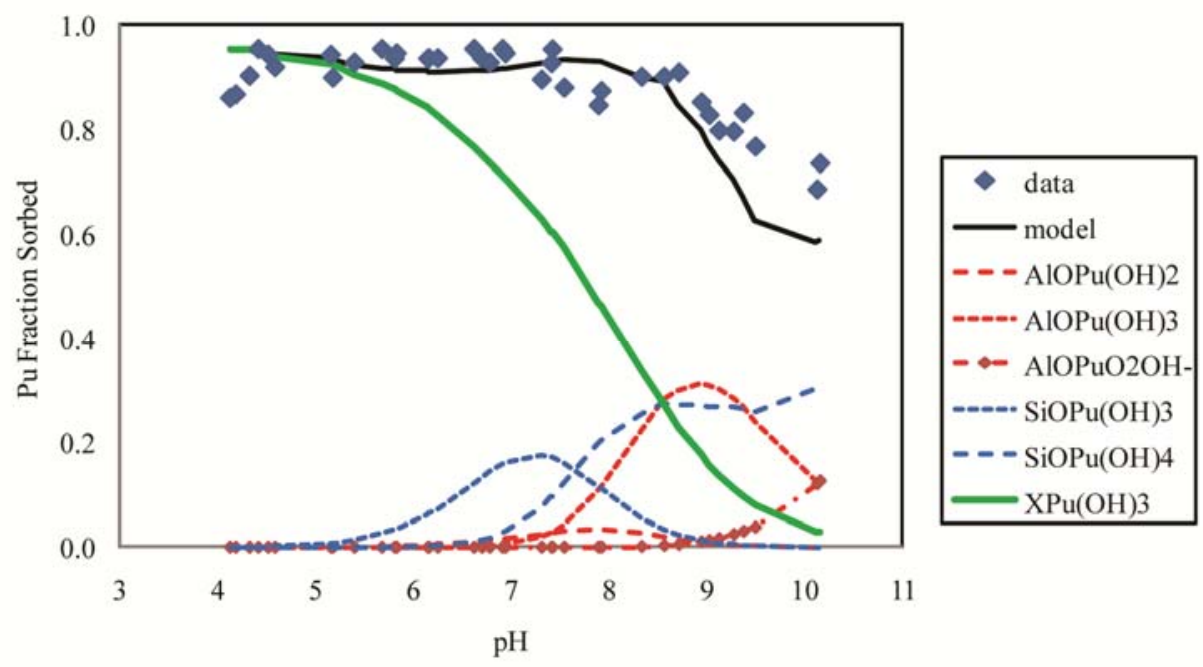

Figure 5.8 Model prediction of Pu sorption to montmorillonite after 24 hours and 62 days with carbonate present assuming both ion exchange and surface complexation. Pu surface complexation constants fixed from Pu-silanol and Pu-aluminol species as listed in Table 5.3. Ion exchange shown as green solid line.

\section{SUMMARY}

Data describing $\mathrm{Pu}$ sorption to silica verified previous observations that $\mathrm{Pu}(\mathrm{V})$ sorption is relatively weak while $\mathrm{Pu}(\mathrm{IV})$ sorption is strong. Similar results were observed for Pu sorption to gibbsite. However, it was interesting that in this work $\mathrm{Pu}$ appears to have a stronger affinity for silica relative to gibbsite. Based on these sorption experiments, a series of $\mathrm{Pu}$-aluminol and $\mathrm{Pu}-$ silanol non-electrostatic surface complexation models (Tables 4.5 and 4.6) were developed to 
describe Pu interactions with silica and gibbsite. These constants were used to predict sorption of $\mathrm{Pu}(\mathrm{IV})$ and $\mathrm{Pu}(\mathrm{V})$ to montmorillonite. Overall, the constants can predict $\mathrm{Pu}(\mathrm{V})$ sorption to montmorillonite across a wide $\mathrm{pH}$ range. This is not the case for $\mathrm{Pu}(\mathrm{IV})$ sorption to montmorillonite at low $\mathrm{pH}$ values although a good fit was obtained in neutral $\mathrm{pH}$. Further incorporation of $\mathrm{Pu}(\mathrm{IV})$ ion exchange could be used to obtain a better fit for $\mathrm{Pu}(\mathrm{IV})$ sorption to montmorillonite. The constants listed in Tables 4.5 and 4.6 can be directly incorporated into the UGTA database. However, some of the inherent complexity of $\mathrm{Pu}$ geochemical behavior is not captured in these systems because they assume that $\mathrm{Pu}$ is present in only one oxidation state, either $\mathrm{Pu}(\mathrm{IV})$ or $\mathrm{Pu}(\mathrm{V})$. Additional modeling was performed in an attempt to capture some of the redox processes that are known to influence $\mathrm{Pu}$ geochemical behavior.

By examining sorption of $\mathrm{Pu}$ to relatively weakly sorbing minerals, the equilibrium distribution and oxidation state of aqueous $\mathrm{Pu}$ in mineral suspensions were more accurately quantified. Due to the strong degree of sorption observed when performing sorption experiments with strongly sorbing minerals such as iron and manganese oxides, the concentration of aqueous Pu is typically too low to allow for accurate oxidation state analysis. Verification of aqueous $\mathrm{Pu}(\mathrm{V})$ in silica and gibbsite suspensions which were initially $\mathrm{Pu}(\mathrm{IV})$ indicated that the equilibrium distribution between aqueous $\mathrm{Pu}(\mathrm{V})$ and solid phase $\mathrm{Pu}(\mathrm{IV})$ must be carefully considered during modeling efforts.

In the current literature, all attempts to develop $\mathrm{Pu}(\mathrm{IV})$ surface complexation models have been done assuming $\mathrm{Pu}(\mathrm{IV})$ is the only oxidation state present. The observation of aqueous $\mathrm{Pu}(\mathrm{V})$ in equilibrium with solid phase $\mathrm{Pu}(\mathrm{IV})$ requires for a change in the modeling approach when analyzing Pu sorption data and describing Pu subsurface transport. The modeling approach described in Chapter 5 where the $\mathrm{Pu}(\mathrm{IV}) / \mathrm{Pu}(\mathrm{V})$ redox couple was included is proposed as a starting point for further model development. The constants are not intended to represent exact values. Rather, the revised modeling effort is proposed for future development and will require further laboratory experiments and modeling exercises. One of the most important considerations regarding this modeling effort is that the $\mathrm{Pu}(\mathrm{IV})$ surface complexation constants are highly dependent on the dissolved oxygen fugacity used in the model. Thus, the constants reported in Table 5.3 are conditional constants applicable only under the simulated $\log \mathrm{O}_{2}(\mathrm{~g})$ values used in the model input.

Whether the surface complexation model presented here is used with or without the $\mathrm{Pu}(\mathrm{IV}) / \mathrm{Pu}(\mathrm{V})$ couple active, it is very important to note that there is no spectroscopic evidence in the present work to verify the assumed solid phase oxidation state distribution or interfacial species. These analyses are necessary for the development of a rigorous surface complexation model. Based upon the model output and experimental data presented in this report, three areas for future research are necessary for a comprehensive model describing $\mathrm{Pu}$ sorption to montmorillonite. These three areas are:

1. Rigorous characterization of $\mathrm{Pu}$ oxidation state speciation at trace $\mathrm{Pu}$ concentrations in homogenous (no solid phase) ground water solutions

2. Spectroscopic verification of the predominance of solid phase $\mathrm{Pu}(\mathrm{IV})$ on non-redox active solid phases such as the gibbsite and silica used in this work. Additionally, experiments at higher $\mathrm{Pu}$ concentration that will allow for EXAFS analysis of the $\mathrm{Pu}$ chemical environment would greatly aid model development. 
3. Detailed evaluation of Pu ion exchange with smectite clays including studies of possible interlayer collapse leading to the formation of "irreversibly" bound Pu within the clay interlayer. Similar to the discussion above, this work will require both batch sorption experiments as well as spectroscopic evaluation.

\section{REFERENCES}

Allard, B., Kipatsi, H., Lilijenzin, J.O., 1980. Expected species of uranium, neptunium and plutonium in neutral aqueous-solutions. Journal of Inorganic and Nuclear Chemistry 42, 1015-1027.

Allard, B., Olofsson, U., Torstenfelt, B., Kipatsi, H., Andersson, K., 1982. Sorption of actinides in welldefined oxidation states on geologic media, in: Lutze, W. (Ed.), Scientific basis for radioactive waste management - V. Elsevier Science Pub. Co., pp. 775-782.

Banik, N.L., Buda, R.A., Burger, S., Kratz, J.V., Trautmann, N., 2007. Sorption of tetravalent plutonium and humic substances onto kaolinite. Radiochimica Acta 95, 569-575.

Bertrand, P.A., Choppin, G.R., 1982. Separation of actinides in different oxidation states by solvent extraction. Radiochimica Acta 31, 135-137.

Bradbury, M.H., Baeyens, B., 2005. Modelling the sorption of Mn(II), Co(II), Ni(II), Zn(II), Cd(II), $\mathrm{Eu}(\mathrm{III}), \mathrm{Am}(\mathrm{III}), \mathrm{Sn}(\mathrm{IV}), \mathrm{Th}(\mathrm{IV}), \mathrm{Np}(\mathrm{V})$ and $\mathrm{U}(\mathrm{VI})$ on montmorillonite: Linear free energy relationships and estimates of surface binding constants for some selected heavy metals and actinides. Geochimica et Cosmochimica Acta 69, 875-892.

Carle, S.F., Maxwell, R.M., Pawloski, G.A., Shumaker, D.E., Tompson, A.F.B., Zavarin, M., 2006. Evaluation of the Transient Hydrologic Source Term for the Cambric Underground Nuclear Test at Frenchman Flat, Nevada Test Site, UCRL-TR-226916, Lawrence Livermore National Laboratory, Livermore, $\mathrm{CA}$.

Clark, D.L., Hobart, D.E., Neu, M.P., 1995. Actinide carbonate complexes and their importance in actinide environmental chemistry. Chemical Reviews 95.

Clark, D.L., Janecky, D.R., Lane, L.J., 2006. Science-based cleanup of Rocky Flats. Physics Today 59, $34-40$.

Cleveland, J.M., 1979. The Chemistry of Plutonium. American Nuclear Society, La Grange Park.

Conradson, S.D., Mahamid, I.A., Clark, D.L., Hess, N.J., Hudson, E.A., Neu, M.P., Palmer, P.D., Runde, W.H., Tait, C.D., 1998. Oxidation state determination of plutonium aquo ions using x-ray absorption spectroscopy. Polyhedron 17, 599-602.

Davis, J.A., Kent, D.B., 1990. Surface complexation modeling in aqueous geochemistry. Reviews in Mineralogy 23, 177-260.

Foti, S.C., Freiling, E.C., 1964. The determination of the oxidation states of tracer uranium, neptunium, and plutonium in aqueous media. Talanta 11, 385-392.

Herbelin, A.L., Westall, J.C., 1994. FITEQL, A computer program for determination of chemical equilibrium constants from experimental data, 3.1 ed. Department of Chemistry, Oregon State University. 
Kaplan, D.I., Powell, B.A., Demirkanli, D.I., Fjeld, R.A., Molz, F.J., Serkiz, S.M., Coates, J.T., 2004. Influence of oxidation states on plutonium mobility during long-term transport through an unsaturated subsurface environment. Environmental Science \& Technology 38, 5053-5058.

Keeney-Kennicutt, W.L., Morse, J.W., 1985. The redox chemistry of Pu(V)O2+ interaction with common mineral surfaces in dilute solutions and seawater. Geochimica et Cosmochimica Acta 49, 2577-2588.

Kobashi, A., Choppin, G.R., 1988. A study of techniquioes for separating plutonium in different oxidation states. Radiochimica Acta 43, 211-215.

Lemire, R.J., Fuguer, J., Nitsche, H., Potter, P., Rand, M.H., Rydberg, J., Spahiu, K., Sullivan, J.C., Ullman, W.J., Votorge, P., Warner, H., 2001. Chemical Thermodymamics of Neptunium and Plutonium. Elsevier, Amsterdam, The Netherlands.

McKinley, J.P., Zachara, J.M., Smith, S.C., Turner, G.D., 1995. The influence of uranyl-hydrolysis and multiple site-binding reaction on adsorption of $\mathrm{U}(\mathrm{VI})$ to montmorillonite. Clays and Clay Minerals 45, 586-598.

Neck, V., Altmaier, M., Seibert, A., Yun, J.I., Marquardt, C.M., Fanghanel, T., 2007. Solubility and redox reactions of $\mathrm{Pu}(\mathrm{IV})$ hydrous oxide: Evidence for the formation of $\mathrm{PuO} 2+\mathrm{x}(\mathrm{s}$, hyd). Radiochimica Acta 95, 193-207.

Neck, V., Kim, J.I., 2001. Solubility and hydrolysis of tetravalent actinides. Radiochimica Acta 89, 1-16.

Neu, M., Hoffman, D.C., Roberts, K.E., Nitsche, H., Silva, R.J., 1994. Comparison of chemical extractions and laser photoacoustic spectroscopy for the determination on plutonium species in nearneutral carbonate solutions. Radiochimica Acta 66/67, 251-258.

Nitsche, H., Lee, S.C., Gatti, R.C., 1988. Determination of plutonium oxidation states at trace levels pertinent to nuclear waste disposal. Journal of Radioanalytical and Nuclear Chemistry 124, 171-185.

Pawloski, G.A., Tompson, A.F.B., Bruton, C.J., Zavarin, M., 2000. Evaluation of the Hydrologic Source Term from Underground Nuclear Tests in Frenchman Flat at the Nevada Test Site (U), UCRL-ID138007-DR, Lawrence Livermore National Laboratory, Livermore, CA.

Pawloski, G.A., Tompson, A.F.B., Carle, S.F., 2001. Evaluation of the hydrologic source term from underground nuclear tests on Pahute Mesa at the Nevada Test Site: The CHESHIRE test, UCRL-ID147023, Lawrence Livermore National Laboratory, Livermore, CA.

Penrose, W.R., Metta, D.N., Hylko, J.M., Rinckel, L.A., 1987. Chemical speciation of plutonium in natural waters. Journal of Environmental Radioactivity 5, 169-184.

Peretrukhin, V.F., Spitsyn, W.I., 1982. Electrochemical determination of the oxidation potentials and the thermodynamic stability of the valence states of the trans-uranium elements in aqueous alkaline media. Izv. Adad. Nauk. SSR, Ser. Khim. 31, 726-730.

Powell, B.A., Duff, M.C., Kaplan, D.I., Fjeld, R.A., Newville, M., Hunter, D.B., Bertsch, P.M., Coates, J.T., Eng, P., Rivers, M.L., Serkiz, S.M., Sutton, S.R., Triay, I.R., Vaniman, D.T., 2006. Plutonium oxidation and subsequent reduction by Mn(IV) minerals in Yucca Mountain tuff. Environmental Science \& Technology 40, 3508-3514.

Powell, B.A., Fjeld, R.A., Kaplan, D.I., Coates, J.T., 2003. Plutonium reduction on synthetic magnetite (Fe3O4) and hematite (alpha-Fe2O3). Abstr Pap Am Chem S 226, U77-U77.

Powell, B.A., Fjeld, R.A., Kaplan, D.I., Coates, J.T., 2004. Plutonium reduction on synthetic magnetite (Fe3O4). Abstr Pap Am Chem S 227, U77-U77.

Powell, B.A., Fjeld, R.A., Kaplan, D.I., Coates, J.T., Serkiz, S.M., 2005. PU(V)0(2)(+) adsorption and reduction by synthetic hematite and goethite. Environmental Science \& Technology 39, 2107-2114. 
Powell, B.A., Kersting, A.B., Zavarin., M., 2008. Sorption and desorption rates of neptunium and plutonium on goethite, in: M. Zavarin, e.a., Editors. (Ed.), Hydrologic resources management program and underground test area project, FY 2006 progress report,. Lawrence Livermore National Laboratory, Livermore, CA, pp. UCRL-TR-404620.

Rai, D., 1984. Solubility product of $\mathrm{Pu}(\mathrm{IV})$ hydrous oxide and equilibrium constants of $\mathrm{Pu}(\mathrm{IV}) / \mathrm{Pu}(\mathrm{V})$, $\mathrm{Pu}(\mathrm{IV}) / \mathrm{Pu}(\mathrm{VI})$, and $\mathrm{Pu}(\mathrm{V}) / \mathrm{Pu}(\mathrm{VI})$ couples. Radiochimica Acta 35, 97-106.

Rai, D., Hess, N.J., Felmy, A.R., Moore, D.A., Yui, M., Vitorge, P., 1999. A thermodynamic model for the solubility of $\mathrm{PuO} 2(\mathrm{am})$ in the aqueous $\mathrm{K}+-\mathrm{HCO} 3-\mathrm{CO} 32--\mathrm{OH}--\mathrm{H} 2 \mathrm{O}$ system. Radiochimica Acta 86, 89-99.

Rai, D., Moore, D.A., Felmy, A.R., Choppin, G.R., Moore, R.C., 2001. Thermodynamics of the PuO2+$\mathrm{Na}+-\mathrm{OH}--\mathrm{Cl}-\mathrm{-ClO} 4--\mathrm{H} 2 \mathrm{O}$ system: Use of $\mathrm{NpO} 2+$ pitzer parameters for $\mathrm{PuO} 2+$. Radiochimica Acta $89,491-498$.

Rai, D., Serne, R.J., Swanson, J.L., 1980. Solution species of Pplutonium in the environment. Journal of Environmental Quality 9, 417-420.

Righetto, L., Bidoglio, G., Azimonti, G., Bellebono, I.R., 1991. Competitive actinide interaction in colloidal humic acid-mineral oxide systems. Environmental Science and Technology 25, 1913-1919.

Sanchez, A.L., 1983. Chemical speciation and adsorption behavior of plutonium in natural waters, Oceanography. University of Washington, Seattle, p. 191.

Sanchez, A.L., Murray, J.W., Sibley, T.H., 1985. The adsorption of plutonium IV and V on goethite. Geochimica et Cosmochimica Acta 49, 2297-2307.

Shaughnessey, D.A., Nitsche, H., Booth, C.H., Shuh, D.K., Waychunas, G.A., Wilson, R.E., Gill, H., Cantrell, K.J., Serne, R.J., 2003. Molecular interfacial teactions between Pu(VI) and manganese oxide minerals manganite and hausmannite. Environmental Science \& Technology 37, 3367-3374.

Soderholm, L., Almond, P.M., Skanthakumar, S., Wilson, R.E., Burns, P.C., 2008. The structure of the plutonium oxide nanocluster [Pu38O56Cl54(H2O)(8)](14-). Angew. Chem.-Int. Edit. 47, 298-302.

Sposito, G., 1977. The gapon and vanselow selectivity coefficients. Soil Science Society of America Journal 41, 1205.

Sposito, G., 1989. The Chemistry of Soils. Oxford University Press, New York.

Stoller-Navarro, 2008. Phase II Transport Model for Corrective Action Unit 98: Frenchman Flat, Nevada Test Site, Nye County, Nevada, Las Vegas, NV.

Tompson, A.F.B., Bruton, C.J., Pawloski, G.A., 1999. Evaluation of the hydrologic source term from the underground nuclear tests in Frenchman Flat and the Nevada Test Site: The CAMBRIC test, Lawrence Livermore National Laboratory, Livermore, CA.

Turner, D.R., 1995. A uniform approach to surface complexation modeling of radionuclide sorption, cnwra 95-001, Center for Nuclear Waste Regulatory Analyses, San Antonio.

Turner, D.R., Pabalan, R.T., Bertetti, F.P., 1998. Neptunium(V) sorption on montmorillonite: An experimental and surface complexation modeling study. Clays and Clay Minerals 46, 256-269.

Vaniman, D., Furlano, A., Chipera, S., Thompson, J., Triay, I., 1996. Microautoradiography in studies of $\mathrm{Pu}(\mathrm{V})$ sorption by trace and fracture minerals in tuff. Materials Research Society Symposium Proceedings Vol 412, 639-645.

White, G.N., Zelazny, L.W., 1988. Analysis and implications of the edge structure of dioctahedral phyllosilicates. Clays and Clay Minerals 36, 141-146. 
Zavarin, M., Bourbin, M., Kersting, A.B., Powell, B.A., Zhao, P.Z., 2008. GEOC 226-Examination of the effects of ionic strength and $\mathrm{pH}$ on neptunium(V) and plutonium(V) sorption to montmorillonite. Abstr Pap Am Chem S 235, 226-GEOC.

Zavarin, M., Bruton, C.J., 2004. A Non-Electrostatic Surface Complexation Approach to Modeling Radionuclide Migration at the Nevada Test Site: Aluminosilicates, UCRL-TR-208672, Lawrence Livermore National Laboratory, Livermore, California. 


\section{APPENDIX A - Solid Phase Charachterization Data Provided by Manufacturer}

Data for Na-Montmorillonite SWy-1 reported by Clay Minerals Repository. (website: http://www.agry.purdue.edu/cjohnston/sourceclays/chem.htm, accessed 01/23/2008)

ORIGIN: Newcastle formation, (cretaceous)

County of Crook, State of Wyoming, USA

LOCATION: NE 1/4 SE 1/4 Sec.18, T 57 N, R 65 W; 8, Topographic map: Seeley(15'), The upper 63 of recently stripped area was removed to expose clean,green upper Newcastle, Collected from which samples was taken, October 3,1972.

CHEMICAL COMPOSITION (\%): $\mathrm{SiO}_{2}: 62.9, \mathrm{Al}_{2} \mathrm{O}_{3}: 19.6, \mathrm{TiO}_{2}: 0.090, \mathrm{Fe}_{2} \mathrm{O}_{3}: 3.35, \mathrm{FeO}: 0.32$, $\mathrm{MnO}: 0.006, \mathrm{MgO}: 3.05, \mathrm{CaO}: 1.68, \mathrm{Na}_{2} \mathrm{O}: 1.53, \mathrm{~K}_{2} \mathrm{O}: 0.53, \mathrm{~F}: 0.111, \mathrm{P}_{2} \mathrm{O}_{5}: 0.049, \mathrm{~S}: 0.05$, Loss on heating: $-550^{\circ} \mathrm{C}: 1.59 ; 550-1000^{\circ} \mathrm{C}: 4.47, \mathrm{CO}_{2}: 1.33$.

CATION EXCHANGE CAPACITY (CEC): 76.4 meq/100g, principal exchange cations $\mathrm{Na}^{+}$and $\mathrm{Ca}^{2+}$.

SURFACE AREA: $\mathrm{N}_{2}$ area: $31.82+/-0.22 \mathrm{~m}^{2} / \mathrm{g}$

THERMAL ANALYSIS: DTA: endotherms at $185^{\circ} \mathrm{C}$ (shoulder at $235^{\circ} \mathrm{C}$ ), desorptionof water: $755^{\circ} \mathrm{C}$, dehydroxylation; shoulder at $810^{\circ} \mathrm{C}$, exotherms at $980^{\circ} \mathrm{C}$. TG: Loss in dehydroxylation range: $5.53 \%$ (theory: $5 \%$ ).

INFRARED SPECTROSCOPY: Typical spectrum for Wyoming bentonite with a moderate $\mathrm{Fe}^{+3}$ content (band at $885 \mathrm{~cm}^{-1}$ ). Quartz is detectable (band at 780, 800,698, 400, and $373 \mathrm{~cm}^{-1}$ ), a trace of carbonate (band at $1425 \mathrm{~cm}^{-1}$ ).

STRUCTURE: $\left(\mathrm{Ca}_{0.12} \mathrm{Na}_{0.32} \mathrm{~K}_{0.05}\right)\left[\mathrm{Al}_{3.01} \mathrm{Fe}(\mathrm{III})_{0.41} \mathrm{Mn}_{0.01} \mathrm{Mg}_{0.54} \mathrm{Ti}_{0.02}\right]\left[\mathrm{Si}_{7.98}\right.$ $\left.\mathrm{Al}_{0.02}\right] \mathrm{O}_{20}(\mathrm{OH})_{4}$, Octahedral charge:-0.53, Tetrahedral charge:-0.02,Interlayer charge:-0.55, Unbalanced charge:0.05, 
Data for IOTA Quartz Sand provided by Unimin Corporation

$21 / 2003 \quad 18: 32 \quad 2039721879$

TECHNICAL DATA
LINIMIN 3RD L

를르르를

PAGE G.3

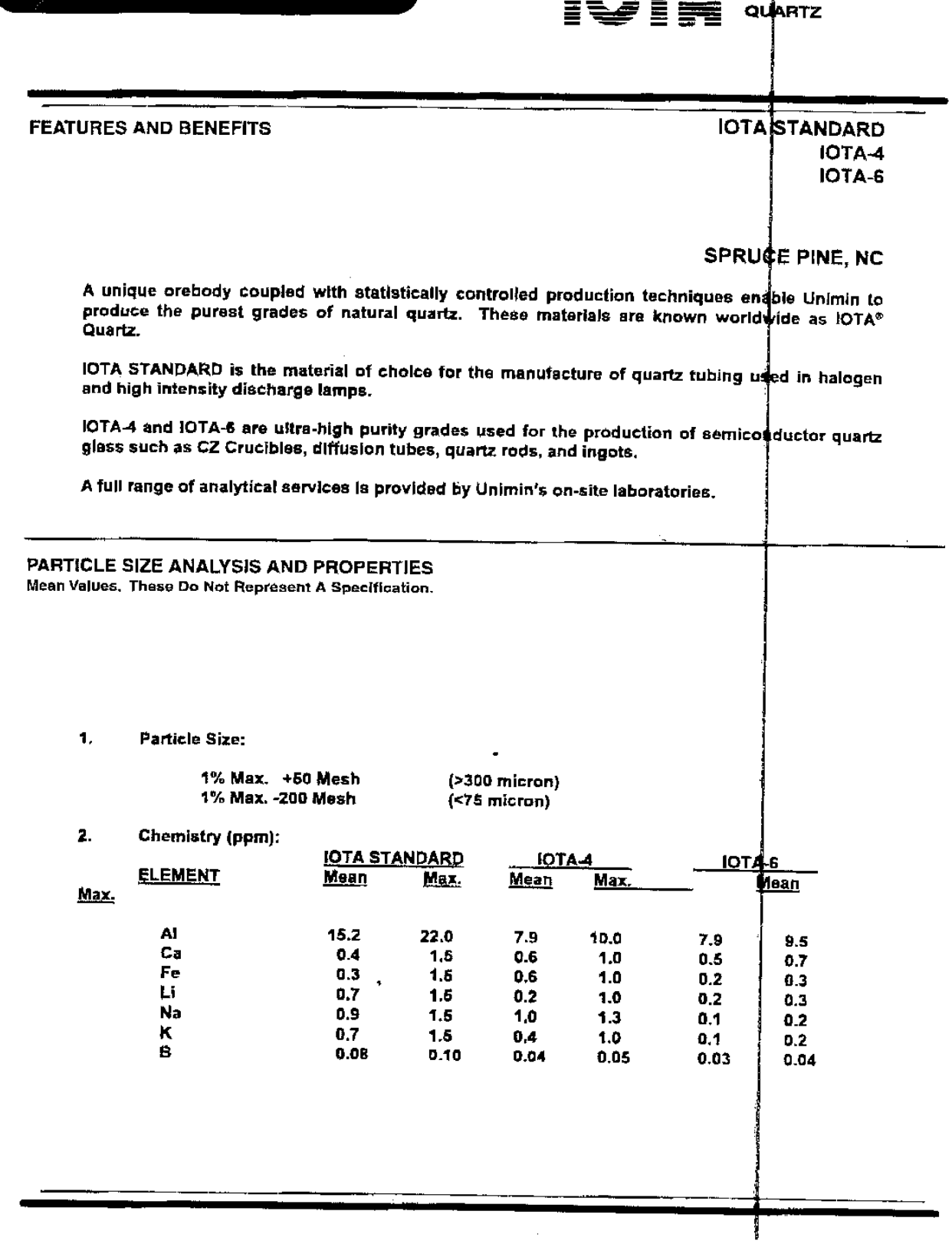




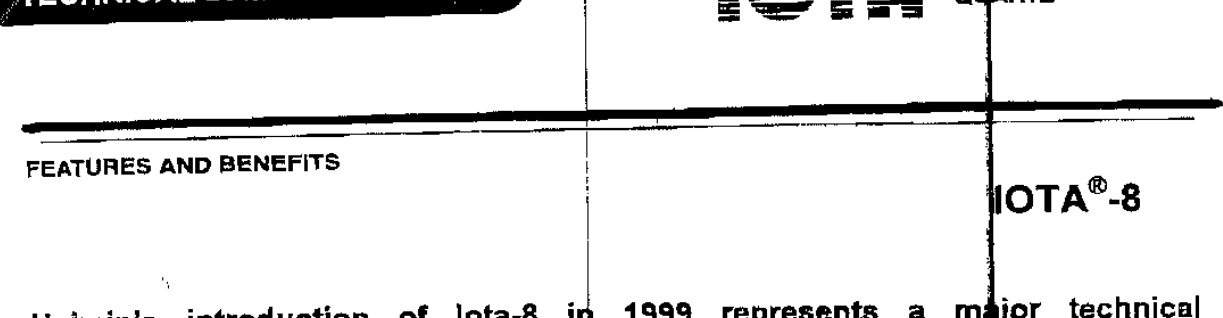

Unimin's introduction of lota-8 in 1999 represents a mpjor technical breakthrough in the purity level obtained from natural quartz fands. Iota-8 was developed with the target of reducing alkali and transition fretals to their lowest posslble levels. The ultra high purity of lota-8 improves devitrification and thermal stability properties, making lota-8 the ideal raw material for large diameter crucibles and as a crucible lining.

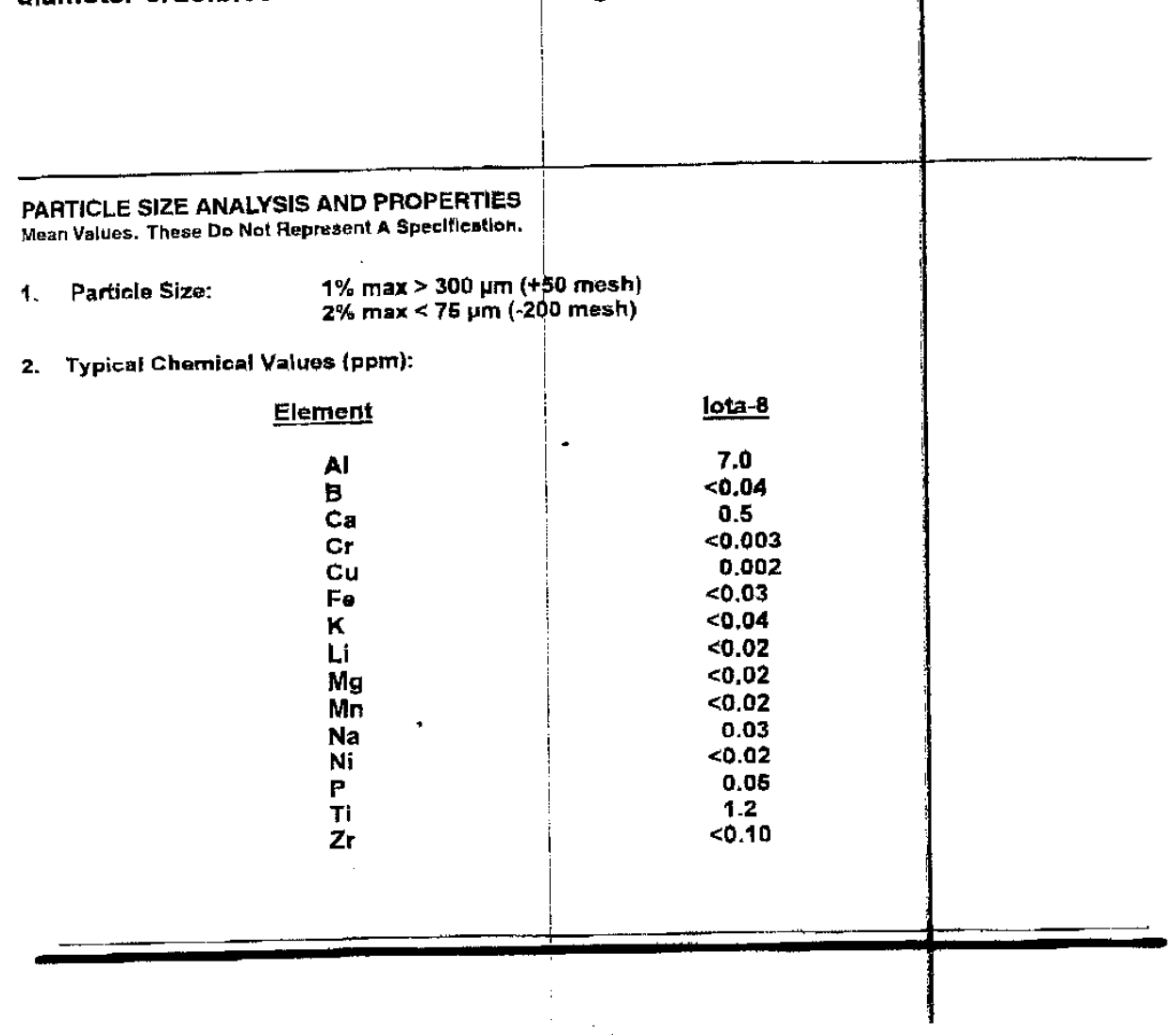




\section{APPENDIX B - Volumes of NaCl, HCl, NaOH, Mineral Suspensions, Pu Working Solutions, and Carbonate Solutions Used for Sample Preparation at I $=0.01 \mathrm{M}$.}

Table B1: Volumes of each solution/suspension required to prepared $10 \mathrm{~mL}$ samples at constant ionic strength for initially $\mathrm{Pu}(\mathrm{IV})$ suspensions without carbonate. For control solutions, an additional $1 \mathrm{~mL}$ of $\mathrm{MQ}_{2} \mathrm{O}$ was added in place of the aliquot of mineral or clay suspension.

\begin{tabular}{|c|c|c|c|c|c|c|}
\hline Target $\mathrm{pH}$ & $\begin{array}{c}0.001 \mathrm{M} \\
\mathrm{HCl}\end{array}$ & $\begin{array}{c}0.10 \mathrm{M} \\
\mathrm{NaCl}\end{array}$ & $\begin{array}{c}0.001 \mathrm{M} \\
\mathrm{NaOH}\end{array}$ & $\mathrm{MQ} \mathrm{H}_{2} \mathrm{O}$ & $\begin{array}{l}\text { Mineral/Clay } \\
\text { Suspension* }\end{array}$ & ${ }^{238} \mathrm{Pu}(\mathrm{V}){ }^{* *}$ \\
\hline 4 & 5.000 & 0.950 & 0.000 & 2.800 & 1.000 & 0.250 \\
\hline 4.5 & 1.666 & 0.980 & 0.000 & 6.104 & 1.000 & 0.250 \\
\hline 5 & 0.500 & 0.990 & 0.000 & 7.260 & 1.000 & 0.250 \\
\hline 5.5 & 0.167 & 1.000 & 0.000 & 7.583 & 1.000 & 0.250 \\
\hline 6 & 0.050 & 1.000 & 0.000 & 7.700 & 1.000 & 0.250 \\
\hline 6.5 & 0.016 & 1.000 & 0.000 & 7.734 & 1.000 & 0.250 \\
\hline 7 & & 1.000 & 0.005 & 7.745 & 1.000 & 0.250 \\
\hline 7.5 & & 1.000 & 0.005 & 7.745 & 1.000 & 0.250 \\
\hline 8 & & 1.000 & 0.025 & 7.725 & 1.000 & 0.250 \\
\hline 8.5 & & 1.000 & 0.050 & 7.700 & 1.000 & 0.250 \\
\hline 9 & & 1.000 & 0.100 & 7.650 & 1.000 & 0.250 \\
\hline 9.5 & & 0.990 & 0.500 & 7.260 & 1.000 & 0.250 \\
\hline 10 & & 0.990 & 1.000 & 6.760 & 1.000 & 0.250 \\
\hline
\end{tabular}

*Based on $100 \mathrm{~m}^{2} \mathrm{~L}^{-1}$ silica and gibbsite suspensions and $46 \mathrm{~m}^{2} \mathrm{~L}^{-1}$ montmorillonite suspension

**See Table 2.1 for exact concentrations, volume was changed to maintain $1.2 \times 10^{-10} \mathrm{M}$ Pu total concentration. Difference in volume was made up by adding or subtracting water to maintain total volume of $10 \mathrm{~mL}$.

Table B2: Volumes of each solution/suspension required to prepared $10 \mathrm{~mL}$ samples at constant ionic strength for initially $\mathrm{Pu}(\mathrm{IV})$ suspensions without carbonate. For control solutions, an additional $1 \mathrm{~mL}$ of $\mathrm{MQ} \mathrm{H}_{2} \mathrm{O}$ was added in place of the aliquot of mineral or clay suspension.

\begin{tabular}{ccccccc}
\hline Target $\mathrm{pH}$ & $\begin{array}{c}0.001 \mathrm{M} \\
\mathrm{HCl}\end{array}$ & $\begin{array}{c}0.10 \mathrm{M} \\
\mathrm{NaCl}\end{array}$ & $\begin{array}{c}0.001 \mathrm{M} \\
\mathrm{NaOH}\end{array}$ & $\begin{array}{c}\mathrm{MQ} \mathrm{H} \mathrm{H}_{2} \mathrm{O} \\
\begin{array}{c}\text { Mineral/Clay } \\
\text { Suspension }\end{array}\end{array}$ & ${ }^{238} \mathrm{Pu}(\mathrm{IV})^{* *}$ \\
\hline \hline 4 & 5.000 & 1.000 & 0.000 & 7.990 & 1.000 & 0.010 \\
5.5 & 1.666 & 1.000 & 0.500 & 7.490 & 1.000 & 0.010 \\
5.5 & 0.500 & 0.990 & 0.900 & 7.100 & 1.000 & 0.010 \\
6 & 0.167 & 0.990 & 0.950 & 7.050 & 1.000 & 0.010 \\
6.5 & 0.050 & 0.990 & 0.990 & 7.010 & 1.000 & 0.010 \\
7 & 0.016 & 0.990 & 0.995 & 7.005 & 1.000 & 0.010 \\
7.5 & & 0.990 & 1.001 & 6.999 & 1.000 & 0.010 \\
8 & & 0.990 & 1.005 & 6.995 & 1.000 & 0.010 \\
8.5 & & 0.990 & 1.010 & 6.990 & 1.000 & 0.010 \\
9 & & 0.990 & 1.050 & 6.950 & 1.000 & 0.010 \\
9.5 & & 0.990 & 1.100 & 6.900 & 1.000 & 0.010 \\
10 & & 0.980 & 1.500 & 6.510 & 1.000 & 0.010 \\
\hline
\end{tabular}

*Based on $100 \mathrm{~m}^{2} \mathrm{~L}^{-1}$ silica and gibbsite suspensions and $46 \mathrm{~m}^{2} \mathrm{~L}^{-1}$ montmorillonite suspension

**See Table 2.2 for exact concentrations, volume was changed to maintain $1.2 \times 10^{-10} \mathrm{M}$ Pu total concentration. Difference in volume was made up by adding or subtracting water to maintain total volume of $10 \mathrm{~mL}$. 
Table B3: Volumes of each solution/suspension required to prepared $10 \mathrm{~mL}$ samples at constant ionic strength for initially $\mathrm{Pu}(\mathrm{V})$ suspensions with carbonate present. Note: Initial $\mathrm{CO}_{2}(\mathrm{~g})$ limited to approximately $0.01 \mathrm{M}$ $\mathrm{HCO}_{3}{ }^{-}$in $\mathrm{pH}>9$ suspensions to maintain ionic strength of $0.01 \mathrm{M}$. For control solutions, an additional $1 \mathrm{~mL}$ of MQ $\mathrm{H}_{2} \mathrm{O}$ was added in place of the aliquot of mineral or clay suspension.

\begin{tabular}{cccccccc}
\hline Target $\mathrm{pH}$ & $\begin{array}{c}0.001 \mathrm{M} \\
\mathrm{HCl}\end{array}$ & $\begin{array}{c}0.1 \mathrm{M} \\
\mathrm{NaCl}\end{array}$ & $\begin{array}{c}0.10 \mathrm{M} \\
\mathrm{NaHCO}_{3}\end{array}$ & $\begin{array}{c}0.10 \mathrm{M} \\
\mathrm{Na}_{2} \mathrm{CO}_{3}\end{array}$ & $\begin{array}{c}\mathrm{MQ} \mathrm{H}_{2} \mathrm{O} \\
\text { Mineral/Clay }\end{array}$ & $\begin{array}{c}{ }^{238} \mathrm{Pu}(\mathrm{V})^{* *} \\
\text { Suspension* }\end{array}$ \\
\hline 4 & 5.000 & 1.000 & 0.002 & & 2.898 & 1.000 & 0.100 \\
5.5 & 1.666 & 1.000 & 0.002 & & 6.232 & 1.000 & 0.100 \\
5.5 & 0.500 & 1.000 & 0.002 & & 7.398 & 1.000 & 0.100 \\
6 & 0.167 & 1.000 & 0.002 & & 7.732 & 1.000 & 0.100 \\
6.5 & 0.050 & 1.000 & 0.002 & & 7.848 & 1.000 & 0.100 \\
7 & 0.016 & 1.000 & 0.004 & & 7.880 & 1.000 & 0.100 \\
7.5 & & 1.000 & 0.009 & & 7.891 & 1.000 & 0.100 \\
8 & & 1.000 & 0.025 & & 7.875 & 1.000 & 0.100 \\
8.5 & & 1.000 & 0.077 & & 7.823 & 1.000 & 0.100 \\
9 & & 0.800 & 0.239 & 0.000 & 7.860 & 1.000 & 0.100 \\
9.5 & & 0.250 & 0.749 & 0.005 & 7.895 & 1.000 & 0.100 \\
10 & & 0.200 & 0.779 & 0.022 & 7.899 & 1.000 & 0.100 \\
\hline
\end{tabular}

*Based on $100 \mathrm{~m}^{2} \mathrm{~L}^{-1}$ silica and gibbsite suspensions and $46 \mathrm{~m}^{2} \mathrm{~L}^{-1}$ montmorillonite suspension

**See Table 2.1 for exact concentrations, volume was changed to maintain $1.2 \times 10^{-10} \mathrm{M}$ Pu total concentration. Difference in volume was made up by adding or subtracting water to maintain total volume of $10 \mathrm{~mL}$.

Table B4: Volumes of each solution/suspension required to prepared $10 \mathrm{~mL}$ samples at constant ionic strength for initially $\mathrm{Pu}(\mathrm{IV})$ suspensions with carbonate present. Note: Initial $\mathrm{CO}_{2}(\mathrm{~g})$ limited to approximately $0.01 \mathrm{M} \mathrm{HCO}_{3}{ }^{-}$in $\mathrm{pH}>9$ suspensions to maintain ionic strength of $0.01 \mathrm{M}$. For control solutions, an additional $1 \mathrm{~mL}$ of $\mathrm{MQ} \mathrm{H}_{2} \mathrm{O}$ was added in place of the aliquot of mineral or clay suspension.

\begin{tabular}{|c|c|c|c|c|c|c|c|}
\hline Target $\mathrm{pH}$ & $\begin{array}{c}0.001 \mathrm{M} \\
\mathrm{HCl} \\
\end{array}$ & $\begin{array}{l}0.1 \mathrm{M} \\
\mathrm{NaCl}\end{array}$ & $\begin{array}{c}0.10 \mathrm{M} \\
\mathrm{NaHCO}_{3} \\
\end{array}$ & $\begin{array}{r}0.10 \mathrm{M} \\
\mathrm{Na}_{2} \mathrm{CO}_{3} \\
\end{array}$ & $\mathrm{MQ} \mathrm{H}_{2} \mathrm{O}$ & $\begin{array}{l}\text { Mineral/Clay } \\
\text { Suspension* }\end{array}$ & ${ }^{238} \mathrm{Pu}(\mathrm{IV}) * *$ \\
\hline 4 & 5.000 & 0.900 & 0.002 & & 3.088 & 1.000 & 0.010 \\
\hline 4.5 & 1.666 & 0.900 & 0.002 & & 6.422 & 1.000 & 0.010 \\
\hline 5 & 0.500 & 0.900 & 0.002 & & 7.588 & 1.000 & 0.010 \\
\hline 5.5 & 0.167 & 0.900 & 0.002 & & 7.922 & 1.000 & 0.010 \\
\hline 6 & 0.050 & 0.900 & 0.002 & & 8.038 & 1.000 & 0.010 \\
\hline 6.5 & 0.016 & 0.900 & 0.004 & & 8.070 & 1.000 & 0.010 \\
\hline 7 & & 0.900 & 0.008 & & 8.082 & 1.000 & 0.010 \\
\hline 7.5 & & 0.900 & 0.025 & & 8.065 & 1.000 & 0.010 \\
\hline 8 & & 0.900 & 0.077 & & 8.013 & 1.000 & 0.010 \\
\hline 8.5 & & 0.700 & 0.239 & 0.000 & 8.050 & 1.000 & 0.010 \\
\hline 9 & & 0.150 & 0.749 & 0.005 & 8.085 & 1.000 & 0.010 \\
\hline 9.5 & & 0.100 & 0.779 & 0.022 & 8.089 & 1.000 & 0.010 \\
\hline 10 & & & 0.851 & 0.065 & 8.075 & 1.000 & 0.010 \\
\hline
\end{tabular}

*Based on $100 \mathrm{~m}^{2} \mathrm{~L}^{-1}$ silica and gibbsite suspensions and $46 \mathrm{~m}^{2} \mathrm{~L}^{-1}$ montmorillonite suspension

**See Table 2.2 for exact concentrations, volume was changed to maintain $1.2 \times 10^{-10} \mathrm{M}$ Pu total concentration.

Difference in volume was made up by adding or subtracting water to maintain total volume of $10 \mathrm{~mL}$. 


\section{APPENDIX C - Sorption Data and Species Concentrations Used for Development of Surface Complexation Model Input Files}

Table C1: $\mathrm{Pu}(\mathrm{IV})$ sorption to gibbsite under $\mathrm{CO}_{2}(\mathrm{~g})$ equilibrated conditions. Note: Reported $\mathrm{HCO}_{3}{ }^{-} / \mathrm{CO}_{3}{ }^{2-}$ concentrations based on initial solution conditions. Some diffusion of $\mathrm{CO}_{2}(\mathrm{~g})$ occurred over the course of the experiment.

\begin{tabular}{|c|c|c|c|c|c|c|c|c|c|c|c|c|c|c|}
\hline $\begin{array}{l}\text { Total Sample } \\
\text { Mass (g) }\end{array}$ & {$\left[\mathrm{Na}^{+}\right]$} & {$\left[\mathrm{Cl}^{-}\right]$} & $\begin{array}{c}{\left[\alpha-\mathrm{Al}(\mathrm{OH})_{3}\right]} \\
\left(\mathrm{m}^{2} \mathrm{~L}^{-1}\right)\end{array}$ & $\begin{array}{l}{\left[\mathrm{HCO}_{3}^{-}\right]} \\
/\left[\mathrm{CO}_{3}{ }^{2-}\right]\end{array}$ & {$[\mathrm{Pu}]_{\text {Total }}$} & $\begin{array}{l}\mathrm{pH} \text { after } \\
24 \text { hours }\end{array}$ & $\begin{array}{c}{[\mathrm{Pu}]_{\text {aqu }} * \text { after }} \\
24 \text { hours }\end{array}$ & $\begin{array}{l}\text { rror }[\mathrm{Pu}]_{\mathrm{aqu}}{ }^{*} \\
\text { fter } 24 \text { hours }\end{array}$ & $\begin{array}{l}\mathrm{pH} \text { after } \\
62 \text { days }\end{array}$ & $\begin{array}{c}{[\mathrm{Pu}]_{\mathrm{aqu}}{ }^{*} \text { after }} \\
62 \text { days }\end{array}$ & $\begin{array}{l}\text { Error }[\mathrm{Pu}]_{\text {aqu }}{ }^{*} \\
\text { after } 62 \text { days }\end{array}$ & $\begin{array}{l}\text { pH after } \\
300 \text { days }\end{array}$ & $\begin{array}{c}\mathrm{Pu}]_{\mathrm{aqu}}{ }^{*} \\
\text { after } 300 \\
\text { days } \\
\end{array}$ & $\begin{array}{l}\text { Error }[\mathrm{Pu}]_{\text {aqu }}{ }^{*} \\
\text { after } 300 \text { days }\end{array}$ \\
\hline & 1 & 0.01 & & 7 & & & & & & & & & 5.89E-11 & \\
\hline & 01 & & & & & & & & & & & & 11 & \\
\hline 050 & 01 & 0.01 & & $4 \mathrm{E}-07$ & $1.34 \mathrm{E}-10$ & 4.63 & 11 & 13 & 4.72 & 11 & 13 & 4.67 & $5.97 \mathrm{E}-11$ & $6 \mathrm{E}-13$ \\
\hline & & & & $1.3 \mathrm{~B}$ & 10 & & & & & & & & 5.39 & \\
\hline & 01 & 0.01 & & 4E-06 & 1.3 & 5.64 & & & & & & 5.2 & $5.25 \mathrm{E}-11$ & -13 \\
\hline 10.024 & 01 & 0.01 & & $4 \mathrm{E}-06$ & 1.34 & 5 . & & & & 1 & & 5.9 & 3.82 & -13 \\
\hline & 1 & & & $1.2 \mathrm{E}$ & & & & & & & & 0.2 & 3.70 & \\
\hline & 01 & 0.01 & & $3.7 \mathrm{E}-05$ & 1.35 & & 11 & 13 & & 2.73 & & 6.62 & $2.73 \mathrm{E}-11$ & -13 \\
\hline 10.020 & & & & 5 & & & & & & & & 6.48 & $3.17 \mathrm{E}-11$ & -13 \\
\hline & & 0.01 & & 11 & 1.35 & 7. & 1 & & & & & & & \\
\hline 9. & & & & & $1.28 \mathrm{E}-10$ & 7.5 & & & & & & & & \\
\hline 10.033 & 0.01 & 0.01 & & 0.00034 & & & & & & & & 7.21 & $2.82 \mathrm{E}-12$ & \\
\hline & & & & 0.00104 & $1.42 \mathrm{~F}$ & & & & & & & & $4.00 \mathrm{E}-12$ & \\
\hline & 01 & 01 & & 0.00316 & 1.3 & 8. & 2 & & 8.28 & 13 & & 8.33 & $6.49 \mathrm{E}-13$ & -14 \\
\hline & & & & 0.00316 & $1.36 \mathrm{E}-10$ & & & & & $6.73 \mathrm{E}-13$ & & 8.38 & $6.71 \mathrm{E}-13$ & \\
\hline 10.059 & 01 & 0.01 & 33 & 0.0072 & $1.30 \mathrm{E}-10$ & 9. & 2.75 & 2. & 8. & 1.03 & -14 & 8.84 & $1.03 \mathrm{E}-12$ & $E-14$ \\
\hline & & & & 0.00846 & $1.32 \mathrm{E}-10$ & & 2.73 & & & -12 & & 9 & $1.32 \mathrm{E}-12$ & $9.01 \mathrm{E}-14$ \\
\hline 10.017 & 0.01 & 0.01 & & 0.00846 & $1.32 \mathrm{E}-10$ & & & & & $1.84 \mathrm{E}-12$ & $9.65 \mathrm{E}-14$ & 9.07 & $1.83 \mathrm{E}-12$ & $9.60 \mathrm{E}-14$ \\
\hline 9.955 & 0.01 & 0.01 & 10.43 & 0.00974 & $1.32 \mathrm{E}-10$ & 10.22 & $3.82 \mathrm{E}-12$ & $2.44 \mathrm{E}-13$ & 10.09 & $5.50 \mathrm{E}-12$ & $1.33 \mathrm{E}-13$ & & & \\
\hline
\end{tabular}

* Measured aqueous phase concentration at sampling time determined via LSC. 
Table C2: $\mathrm{Pu}(\mathrm{IV})$ sorption to silica under $\mathrm{CO}_{2}$ (g) equilibrated conditions. Note: Reported $\mathrm{HCO}_{3}{ }^{-} / \mathrm{CO}_{3}{ }^{2-}$ concentrations based on initial solution conditions. Some diffusion of $\mathrm{CO}_{2}(\mathrm{~g})$ occurred over the course of the experiment.

\begin{tabular}{|c|c|c|c|c|c|c|c|c|c|c|c|}
\hline $\begin{array}{c}\text { Total Sampl } \\
\text { Mass (g) } \\
\end{array}$ & & $\left.1^{-}\right]$ & $\begin{array}{r}{\left[\mathrm{SiO}_{2}\right]} \\
\left(\mathrm{m}^{2} \mathrm{~L}^{-1}\right) \\
\end{array}$ & $\begin{array}{l}{\left[\mathrm{HCO}_{3}^{-}\right]} \\
/\left[\mathrm{CO}_{3}^{2-}\right] \\
\end{array}$ & {$[\mathrm{Pu}]_{\text {Total }}$} & $\begin{array}{l}\mathrm{pH} \text { after } \\
24 \text { hours } \\
\end{array}$ & $\begin{array}{c}{[\mathrm{Pu}]_{\mathrm{aqu}}{ }^{*} \text { after }} \\
24 \text { hours } \\
\end{array}$ & $\begin{array}{l}\text { Error }[\mathrm{Pu}]_{\mathrm{aqu}}{ }^{*} \\
\text { after } 24 \text { hours } \\
\end{array}$ & $\begin{array}{l}\mathrm{pH} \text { after } \\
62 \text { days } \\
\end{array}$ & $\begin{array}{c}{[\mathrm{Pu}]_{\mathrm{aqu}} * \text { after }} \\
62 \text { days } \\
\end{array}$ & $\begin{array}{c}\text { Error }[\mathrm{Pu}]_{\text {aqu }}{ }^{*} \\
\text { after } 62 \text { days } \\
\end{array}$ \\
\hline 10.070 & 0.01 & 0.01 & 10.35 & $1.44 \mathrm{E}-07$ & $1.36 \mathrm{E}-10$ & 3.87 & $4.99 \mathrm{E}-11$ & $8.73 \mathrm{E}-13$ & 3.88 & $6.61 \mathrm{E}-11$ & $4.97 \mathrm{E}-13$ \\
\hline 10.069 & 0.0 & 0.01 & 10.35 & $4.38 \mathrm{E}-07$ & $1.33 \mathrm{E}-10$ & 4.51 & $1.68 \mathrm{E}-11$ & 4.47E-13 & 4.44 & $4.36 \mathrm{E}-11$ & $3.96 \mathrm{E}-13$ \\
\hline 10.012 & 0.01 & 0.01 & 10.35 & 4.38E-07 & $1.35 \mathrm{E}-10$ & 4.31 & $3.11 \mathrm{E}-11$ & $6.37 \mathrm{E}-13$ & 4.24 & $5.05 \mathrm{E}-11$ & $4.68 \mathrm{E}-13$ \\
\hline 10.042 & 0.01 & .01 & 10.35 & $1.33 \mathrm{E}-06$ & $1.34 \mathrm{E}-10$ & 4.92 & $1.68 \mathrm{E}-11$ & $4.45 \mathrm{E}-13$ & 4.75 & $2.38 \mathrm{E}-11$ & $2.70 \mathrm{E}-13$ \\
\hline 10.044 & 0 & 01 & 10.35 & 4.03 & $1.34 \mathrm{E}-10$ & 5.62 & $1.13 \mathrm{E}-11$ & $3.68 \mathrm{E}-13$ & 5.62 & $5.66 \mathrm{E}-12$ & $1.34 \mathrm{E}-13$ \\
\hline 10.018 & $0 .($ & .01 & 10.35 & $4.03 \mathrm{E}-06$ & $1.35 \mathrm{E}-10$ & 5.62 & $1.07 \mathrm{E}-11$ & $3.58 \mathrm{E}-13$ & 5.35 & $4.16 \mathrm{E}-12$ & $20 \mathrm{E}-13$ \\
\hline 10.006 & 0. & .01 & 10.35 & 1.22 & 1.36 & 6.13 & $1.27 \mathrm{E}-11$ & -13 & 5.7 & 2.3 & E-13 \\
\hline 9.945 & 0.0 & .01 & 10.35 & 3.72E-05 & $1.35 \mathrm{E}-10$ & 6.85 & $1.55 \mathrm{E}-11$ & $4.30 \mathrm{E}-13$ & 6.66 & $8.17 \mathrm{E}-13$ & $8.40 \mathrm{E}-14$ \\
\hline 10.037 & 0.01 & 0.01 & 10.35 & $3.72 \mathrm{E}-05$ & $1.36 \mathrm{E}-10$ & 6.57 & $8.42 \mathrm{E}-12$ & $3.23 \mathrm{E}-13$ & 6.37 & $4.30 \mathrm{E}-13$ & $7.91 \mathrm{E}-14$ \\
\hline 10.076 & 0.01 & 0.01 & 10.35 & $1.13 \mathrm{E}-04$ & $1.32 \mathrm{E}-10$ & 6.93 & $1.38 \mathrm{E}-11$ & $4.06 \mathrm{E}-13$ & 6.81 & $7.82 \mathrm{E}-13$ & $8.35 \mathrm{E}-14$ \\
\hline 10.019 & 0.01 & 0.01 & 10.35 & $3.43 \mathrm{E}-04$ & $1.35 \mathrm{E}-10$ & 7.36 & $1.36 \mathrm{E}-11$ & $4.02 \mathrm{E}-13$ & 7.31 & $1.10 \mathrm{E}-12$ & $8.74 \mathrm{E}-14$ \\
\hline 10.025 & 0.01 & .01 & 10.35 & 3.42 & 1.3 & 7.25 & $1.10 \mathrm{E}-11$ & 3.6 & 7.31 & 12 & -14 \\
\hline & & 01 & 1 & 3 & 1.3 & 7.96 & 1.16 & 13 & 7. & 1.4 & -14 \\
\hline 10.090 & 0 & 0.01 & 10.35 & 3.1 & & 8.02 & 9.73 & & 8. & 2.0 & -14 \\
\hline 9.974 & 0 . & 0.01 & 10.35 & 3.16 & 1.36 & 8.7 & 1.13 & 13 & 8.39 & 2.1 & -14 \\
\hline 10.028 & 0.0 & 0.01 & 10.35 & $7.20 \mathrm{E}-03$ & $1.35 \mathrm{E}-10$ & 9.03 & $1.36 \mathrm{E}-11$ & $4.02 \mathrm{E}-13$ & 8.84 & $3.68 \mathrm{E}-12$ & $1.15 \mathrm{E}-13$ \\
\hline 83 & 0. & 0.01 & 10.35 & $8.47 \mathrm{E}-03$ & $1.36 \mathrm{E}-10$ & 9.51 & $1.57 \mathrm{E}-11$ & $4.33 \mathrm{E}-13$ & 9.22 & $5.24 \mathrm{E}-12$ & $1.30 \mathrm{E}-13$ \\
\hline 10.000 & 0.0 & .01 & 10.35 & $8.47 \mathrm{E}-03$ & $1.33 \mathrm{E}-10$ & 9.63 & $2.15 \mathrm{E}-11$ & $5.13 \mathrm{E}-13$ & 9.28 & $6.47 \mathrm{E}-12$ & $1.52 \mathrm{E}-13$ \\
\hline 10.062 & 0.01 & 0.01 & 10.35 & $9.77 \mathrm{E}-03$ & $1.35 \mathrm{E}-10$ & 10.17 & $1.99 \mathrm{E}-11$ & $4.92 \mathrm{E}-13$ & 9.88 & $7.06 \mathrm{E}-12$ & $1.46 \mathrm{E}-13$ \\
\hline
\end{tabular}

* Measured aqueous phase concentration at sampling time determined via LSC.

Table C3: $\mathrm{Pu}(\mathrm{IV})$ Sorption to gibbsite under $\mathrm{CO}_{2}(\mathrm{~g})$-free conditions. Note: Data at 62 days is shown but was not used in the report or modeling efforts due to $\mathrm{CO}_{2}(\mathrm{~g})$ diffusion into the vial.

\begin{tabular}{|c|c|c|c|c|c|c|c|c|c|c|}
\hline $\begin{array}{c}\text { Total Sample } \\
\text { Mass (g) } \\
\end{array}$ & {$\left[\mathrm{Na}^{+}\right]$} & {$\left[\mathrm{Cl}^{-}\right]$} & $\begin{array}{c}{\left[\alpha-\mathrm{Al}(\mathrm{OH})_{3}\right]} \\
\left(\mathrm{m}^{2} \mathrm{~L}^{-1}\right) \\
\end{array}$ & {$[\mathrm{Pu}]_{\text {Total }}$} & $\begin{array}{l}\mathrm{pH} \text { after } \\
24 \text { hours } \\
\end{array}$ & $\begin{array}{c}{[\mathrm{Pu}]_{\mathrm{aqu}} * \text { after }} \\
24 \text { hours } \\
\end{array}$ & $\begin{array}{l}\text { Error }[\mathrm{Pu}]_{\text {aqu }}{ }^{*} \\
\text { after } 24 \text { hours }\end{array}$ & $\begin{array}{l}\mathrm{pH} \text { after } \\
62 \text { days } \\
\end{array}$ & $\begin{array}{c}\mathrm{Pu}]_{\text {aqu }}{ }^{*} \text { after } \\
62 \text { days } \\
\end{array}$ & $\begin{array}{l}\text { Error }[\mathrm{Pu}]_{\text {aqu }}{ }^{*} \\
\text { after } 62 \text { days } \\
\end{array}$ \\
\hline 10.006 & 0.01 & 0.01 & 9.99 & $1.24 \mathrm{E}-10$ & 3.89 & $2.07 \mathrm{E}-11$ & $4.98 \mathrm{E}-13$ & 4.22 & $2.21 \mathrm{E}-11$ & $5.33 \mathrm{E}-13$ \\
\hline 10.091 & 0.01 & 0.01 & 9.91 & $1.23 \mathrm{E}-10$ & 4.62 & $1.12 \mathrm{E}-11$ & $3.77 \mathrm{E}-13$ & 4.49 & $2.36 \mathrm{E}-11$ & $5.50 \mathrm{E}-13$ \\
\hline 10.092 & 0.01 & 0.01 & 9.91 & $1.23 \mathrm{E}-10$ & 4.87 & $8.79 \mathrm{E}-12$ & $3.43 \mathrm{E}-13$ & 4.76 & $2.79 \mathrm{E}-11$ & $5.98 \mathrm{E}-13$ \\
\hline 10.001 & 0.01 & 0.01 & 10.00 & $1.24 \mathrm{E}-10$ & 4.93 & $8.63 \mathrm{E}-12$ & $3.41 \mathrm{E}-13$ & 4.85 & $1.08 \mathrm{E}-11$ & $3.96 \mathrm{E}-13$ \\
\hline 10.071 & 0.01 & 0.01 & 9.93 & $1.23 \mathrm{E}-10$ & 5.87 & $8.33 \mathrm{E}-12$ & $3.36 \mathrm{E}-13$ & 4.85 & $1.10 \mathrm{E}-11$ & $3.99 \mathrm{E}-13$ \\
\hline 10.110 & .01 & 0.01 & 9.89 & $1.23 \mathrm{E}-10$ & 6.06 & 7.77E-12 & $3.28 \mathrm{E}-13$ & 5.54 & $9.20 \mathrm{E}-12$ & $3.75 \mathrm{E}-13$ \\
\hline 10.118 & 0.01 & 0.01 & 9.88 & $1.23 \mathrm{E}-10$ & 6.22 & $8.46 \mathrm{E}-12$ & $3.38 \mathrm{E}-13$ & 5.87 & $1.44 \mathrm{E}-11$ & $4.42 \mathrm{E}-13$ \\
\hline 10.099 & 0.01 & 0.01 & 9.90 & $1.23 \mathrm{E}-10$ & 6.57 & $8.13 \mathrm{E}-12$ & E-13 & 6.19 & 7.46E-12 & $3.51 \mathrm{E}-13$ \\
\hline 10.059 & 0.01 & 0.01 & 9.94 & $1.23 \mathrm{E}-10$ & 6.71 & $7.56 \mathrm{E}-12$ & $3.25 \mathrm{E}-13$ & 6.32 & $7.70 \mathrm{E}-12$ & $3.55 \mathrm{E}-13$ \\
\hline 10.083 & 0.01 & 0.01 & 9.92 & $1.23 \mathrm{E}-10$ & 6.89 & $6.56 \mathrm{E}-12$ & $3.10 \mathrm{E}-13$ & 6.27 & $7.81 \mathrm{E}-12$ & $3.56 \mathrm{E}-13$ \\
\hline 10.133 & 0.01 & 0.01 & 9.87 & $1.23 \mathrm{E}-10$ & 7.05 & 7.83E-12 & $3.29 \mathrm{E}-13$ & 6.37 & 7.99E-12 & $3.59 \mathrm{E}-13$ \\
\hline 10.108 & 0.01 & 0.01 & 9.89 & $1.23 \mathrm{E}-10$ & 7.72 & $8.77 \mathrm{E}-12$ & $3.43 \mathrm{E}-13$ & 6.49 & $1.28 \mathrm{E}-11$ & $4.21 \mathrm{E}-13$ \\
\hline 10.056 & 0.01 & 0.01 & 9.94 & $1.23 \mathrm{E}-10$ & 7.87 & $9.34 \mathrm{E}-12$ & $3.51 \mathrm{E}-13$ & 6.77 & $1.14 \mathrm{E}-11$ & $4.04 \mathrm{E}-13$ \\
\hline & .01 & 0.01 & 10.05 & $1.25 \mathrm{E}-10$ & 8.2 & $7.56 \mathrm{E}-12$ & $3.25 \mathrm{E}-13$ & 6.68 & $1.44 \mathrm{E}-11$ & $4.42 \mathrm{E}-13$ \\
\hline 10.570 & 0.01 & 0.01 & 9.46 & $1.17 \mathrm{E}-10$ & 8.37 & 7.44E-12 & $3.23 \mathrm{E}-13$ & 6.8 & $1.48 \mathrm{E}-11$ & $4.46 \mathrm{E}-13$ \\
\hline 9.939 & 0.01 & 0.01 & 10.06 & $1.25 \mathrm{E}-10$ & 8.73 & $5.71 \mathrm{E}-12$ & $2.97 \mathrm{E}-13$ & 6.87 & $1.50 \mathrm{E}-11$ & $4.49 \mathrm{E}-13$ \\
\hline 10.073 & 0.01 & 0.01 & 9.93 & $1.23 \mathrm{E}-10$ & 9.3 & $3.81 \mathrm{E}-12$ & $2.66 \mathrm{E}-13$ & 7.1 & $7.72 \mathrm{E}-12$ & $3.55 \mathrm{E}-13$ \\
\hline 10.077 & 0.01 & 0.01 & 9.92 & $1.23 \mathrm{E}-10$ & 9.47 & $3.40 \mathrm{E}-12$ & $2.59 \mathrm{E}-13$ & 7.3 & $7.02 \mathrm{E}-12$ & $3.46 \mathrm{E}-13$ \\
\hline 10.123 & 0.01 & 0.01 & 9.88 & $1.23 \mathrm{E}-10$ & 9.97 & $3.35 \mathrm{E}-12$ & $2.58 \mathrm{E}-13$ & 7.83 & $1.72 \mathrm{E}-12$ & $2.67 \mathrm{E}-13$ \\
\hline
\end{tabular}

* Measured aqueous phase concentration at sampling time determined via LSC. 
Table C4: $\mathrm{Pu}(\mathrm{IV})$ Sorption to silica under $\mathrm{CO}_{2}(\mathrm{~g})$-free conditions. Note: Data at 62 days is shown but was not used in the report or modeling efforts due to $\mathrm{CO}_{2}(\mathrm{~g})$ diffusion into the vial.

\begin{tabular}{|c|c|c|c|c|c|c|c|c|c|c|}
\hline $\begin{array}{l}\text { Total Sample } \\
\text { Mass (g) }\end{array}$ & {$\left[\mathrm{Na}^{+}\right]$} & {$\left[\mathrm{Cl}^{-}\right]$} & $\begin{array}{l}{\left[\mathrm{SiO}_{2}\right]} \\
\left(\mathrm{m}^{2} \mathrm{~L}^{-1}\right)\end{array}$ & {$[\mathrm{Pu}]_{\text {Total }}$} & $\begin{array}{l}\mathrm{pH} \text { after } \\
24 \text { hours }\end{array}$ & $\begin{array}{c}{[\mathrm{Pu}]_{\text {aqu* after } 24} 24} \\
\text { hours }\end{array}$ & $\begin{array}{l}\text { rror }[\mathrm{Pu}]_{\mathrm{aqu}}{ }^{*} \\
\text { fter } 24 \text { hours }\end{array}$ & $\begin{array}{l}\mathrm{pH} \text { after } \\
60 \text { days }\end{array}$ & $\begin{array}{c}{[\mathrm{Pu}]_{\mathrm{aqu}} * \text { after }} \\
60 \text { days }\end{array}$ & $\begin{array}{c}\text { Error } \\
{[\mathrm{Pu}]_{\mathrm{aqu}}{ }^{*} \text { after }} \\
60 \text { days } \\
\end{array}$ \\
\hline 10.112 & 01 & 01 & 9.89 & $1.23 \mathrm{E}-10$ & 4.16 & 7 & $89 \mathrm{E}-13$ & 4.52 & 2.67 & $4.67 \mathrm{E}-13$ \\
\hline & & 1 & 9 & 0 & & & & & & -13 \\
\hline 10.124 & .01 & 01 & 9.88 & $1.23 \mathrm{E}-10$ & 4.6 & $46 \mathrm{E}-11$ & $\mathrm{~J}$ & .67 & 11 & $4.37 \mathrm{E}-13$ \\
\hline 9.967 & 0.01 & .01 & 10.03 & $1.25 \mathrm{E}-10$ & 5.07 & & $20 \mathrm{E}$ & .0 & & $2.83 \mathrm{E}-13$ \\
\hline 10.146 & 01 & 01 & 9.8 & $1.22 \mathrm{E}-10$ & 5.7 & 2.71 & & 6.0 & 12 & $2.85 \mathrm{E}-13$ \\
\hline 10. & 01 & 1 & 9.90 & & 6.1 & & & & & -13 \\
\hline & $0 .($ & & 10.86 & & & & & & & \\
\hline 10 & 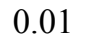 & 1 & & & & & & & & 13 \\
\hline 10 & $0 .($ & 1 & 9.9 & & 6. & & & & & 2.1 \\
\hline 10.089 & 0.01 & 0.01 & 9.9 & 1.2 & 6.9 & 3. & & .53 & 13 & $2.12 \mathrm{E}-13$ \\
\hline 10.079 & 0.01 & 0.01 & 9.92 & $1.23 \mathrm{E}-10$ & 7.11 & 3.191 & 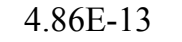 & 6.53 & -13 & $2.10 \mathrm{E}-13$ \\
\hline 10.120 & 0.01 & 0.01 & 9.8 & $1.23 \mathrm{E}-10$ & 7.4 & $2.20 \mathrm{I}$ & 3.82 & 6 & 13 & $2.11 \mathrm{E}-13$ \\
\hline 10.101 & 0.01 & .01 & 9.9 & $1.23 \mathrm{E}-10$ & 7.8 & 2.41 & 4.05 & 6.68 & 5.3 & $2.12 \mathrm{E}-13$ \\
\hline 13.480 & 0.01 & .01 & 7.42 & 9.21 & 7.9 & $2.52 \mathrm{E}$ & & 1 & & $2.10 \mathrm{E}-13$ \\
\hline & 0. & & .03 & & .27 & & & 0 & -12 & $2.17 \mathrm{E}-13$ \\
\hline & 0.0 & .0 & 11.25 & & & & & & & $2.10 \mathrm{E}-13$ \\
\hline & 0.0 & 0 & & & & & & & & 2.20 \\
\hline & $0 .($ & & & & & & & & & $2.24 \mathrm{E}-13$ \\
\hline 10.122 & 0.01 & 0.01 & 9.88 & $1.23 \mathrm{E}-10$ & 9.67 & $2.93 \mathrm{E}-11$ & $4.58 \mathrm{E}-13$ & 8.56 & $5.56 \mathrm{E}-12$ & $2.61 \mathrm{E}-13$ \\
\hline
\end{tabular}

* Measured aqueous phase concentration at sampling time determined via LSC. 
Table C5: $\mathrm{Pu}(\mathrm{V})$ sorption to gibbsite under $\mathrm{CO}_{2}(\mathrm{~g})$ equilibrated conditions. Note: Reported $\mathrm{HCO}_{3}{ }^{-} / \mathrm{CO}_{3}{ }^{2-}$ concentrations based on initial solution conditions. Some diffusion of $\mathrm{CO}_{2}(\mathrm{~g})$ occurred over the course of the experiment.

\begin{tabular}{|c|c|c|c|c|c|c|c|c|c|c|c|c|c|c|}
\hline $\begin{array}{l}\text { Total Sample } \\
\text { Mass (g) }\end{array}$ & {$\left[\mathrm{Na}^{+}\right]$} & {$\left[\mathrm{Cl}^{-}\right]$} & $\begin{array}{c}{\left[\alpha-\mathrm{Al}(\mathrm{OH})_{3}\right]} \\
\left(\mathrm{m}^{2} \mathrm{~L}^{-1}\right)\end{array}$ & $\begin{array}{l}{\left[\mathrm{HCO}_{3}{ }^{-}\right]} \\
/\left[\mathrm{CO}_{3}{ }^{2-}\right]\end{array}$ & {$[\mathrm{Pu}]_{\text {Total }}$} & $\begin{array}{l}\mathrm{pH} \text { after } \\
24 \text { hours }\end{array}$ & $\begin{array}{c}{[\mathrm{Pu}]_{\text {aqu }} * \text { after }} \\
24 \text { hours }\end{array}$ & $\begin{array}{l}\text { Error }[\mathrm{Pu}]_{\mathrm{aqu}}{ }^{*} \\
\text { after } 24 \text { hours }\end{array}$ & $\begin{array}{l}\mathrm{pH} \text { after } \\
62 \text { days }\end{array}$ & $\begin{array}{c}{[\mathrm{Pu}]_{\mathrm{aqu}} * \text { after }} \\
62 \text { days }\end{array}$ & $\begin{array}{l}\text { Error }[\mathrm{Pu}]_{\text {aqu }}{ }^{*} \\
\text { after } 62 \text { days }\end{array}$ & $\begin{array}{c}\mathrm{pH} \text { after } \\
300 \\
\text { days } \\
\end{array}$ & $\begin{array}{c}{[\mathrm{Pu}]_{\mathrm{aqu}} *} \\
\text { after } 300 \\
\text { days } \\
\end{array}$ & $\begin{array}{l}\text { Error }[\mathrm{Pu}]_{\mathrm{aqu}}{ }^{*} \\
\text { after } 300 \text { days }\end{array}$ \\
\hline 10.068 & 0.01 & 0.01 & 28 & $1.44 \mathrm{E}-7$ & $18 \mathrm{E}-10$ & 3 & 10 & & & & & 4.4 & $1.14 \mathrm{E}-10$ & 13 \\
\hline 10.039 & 0.01 & 0.01 & 31 & $4.37 \mathrm{E}-7$ & $18 \mathrm{E}-10$ & 3 & 10 & & & & & 4.45 & $1.17 \mathrm{E}-10$ & -13 \\
\hline 9.983 & 0.01 & 0.01 & 8 & $4.37 \mathrm{E}-7$ & $1.19 \mathrm{E}-10$ & 4.48 & 1.18 & 1 & 4 & 10 & 10 & 4.59 & $1.14 \mathrm{E}-10$ & 13 \\
\hline 9.999 & 0.01 & 0.01 & & E-6 & $1.19 \mathrm{I}$ & 5.03 & & & & & & 4.88 & $8.87 \mathrm{E}-11$ & -13 \\
\hline 10.054 & 0.01 & 0.01 & 10.33 & $4.03 \mathrm{E}-6$ & $1.18 \mathrm{E}-10$ & 5.63 & $1.14 \mathrm{E}-10$ & $1.64 \mathrm{E}-12$ & 5.36 & $1.12 \mathrm{~F}$ & $1.12 \mathrm{E}-10$ & 5.32 & $8.16 \mathrm{E}-11$ & $6.25 \mathrm{E}-13$ \\
\hline & 0.01 & 0.01 & & $4.03 \mathrm{E}-6$ & $1.19 \mathrm{E}-10$ & 5.76 & & & & & & 5.61 & $7.96 \mathrm{E}-11$ & \\
\hline 10.175 & 0.01 & 0.01 & 1015 & $1.22 \mathrm{E}-5$ & $1.16 \mathrm{E}-10$ & 6.04 & $1.09 \mathrm{E}-10$ & $1.58 \mathrm{E}-12$ & 6.13 & $1.02 \mathrm{E}-10$ & $1.02 \mathrm{E}-10$ & 6.06 & $6.79 \mathrm{E}-11$ & $5.44 \mathrm{E}-13$ \\
\hline & 0.01 & & & & & & & & & & & 6.7 & 2.29 & \\
\hline 9.984 & 0.01 & 0.01 & 10.40 & $3.71 \mathrm{E}-5$ & $1.19 \mathrm{E}-10$ & 6.67 & $1.03 \mathrm{E}-10$ & $1.50 \mathrm{E}-12$ & 6.61 & 8.67 & 8.67 & 6.41 & $5.82 \mathrm{E}-11$ & -13 \\
\hline 9.887 & 0.01 & 0.01 & 10.48 & 0.000112 & $1.21 \mathrm{E}-10$ & & $9.02 \mathrm{E}-11$ & $1.35 \mathrm{E}-12$ & 6.96 & 5.74 & 5.7 & & & \\
\hline 10.215 & 0.01 & 0.01 & 10.12 & 0.00 & $1.16 \mathrm{E}-10$ & 7.51 & 7.37 & 12 & 7.25 & 1.00 & 1.00 & 7.23 & 3.01 & -13 \\
\hline & 0.01 & 0.01 & 10.41 & 0.000342 & $1.19 \mathrm{E}-10$ & 7.57 & $6.67 \mathrm{E}-11$ & $1.08 \mathrm{E}-12$ & 7.47 & $1.21 \mathrm{E}-11$ & $1.21 \mathrm{E}-11$ & 7.38 & $5.12 \mathrm{E}-13$ & $7.29 \mathrm{E}-14$ \\
\hline 9.965 & 0.01 & 0.01 & 10.39 & 0.00104 & $1.19 \mathrm{E}-10$ & 7.99 & $3.96 \mathrm{E}-11$ & 7.4 & 7.8 & $1.28 \mathrm{E}-12$ & $1.28 \mathrm{E}-12$ & & & \\
\hline & 0.01 & 0.01 & 10.35 & 0.003157 & $1.19 \mathrm{E}-10$ & 8.52 & $2.85 \mathrm{E}-11$ & $6.05 \mathrm{E}-13$ & 8.25 & $3.82 \mathrm{E}-13$ & $3.82 \mathrm{E}-13$ & 8.29 & $7.21 \mathrm{E}-13$ & \\
\hline 9.947 & 0.01 & 0.01 & 10.43 & 0.00 & $1.19 \mathrm{H}$ & & & 6.2 & & 6.3 & 6.30 & 8.35 & $4.03 \mathrm{E}-13$ & -14 \\
\hline 9.997 & 0.01 & 0.01 & 10.39 & 0.00720 & $1.19 \mathrm{E}-10$ & 9.05 & $2.62 \mathrm{E}-11$ & $5.76 \mathrm{E}-13$ & 8.91 & $6.06 \mathrm{E}-13$ & $6.06 \mathrm{E}-13$ & 8.78 & $1.11 \mathrm{E}-12$ & $8.17 \mathrm{E}-14$ \\
\hline 10.010 & 0.01 & 0.01 & 10.37 & 0.00845 & $1.19 \mathrm{E}-10$ & 9.43 & $2.12 \mathrm{E}-11$ & $5.08 \mathrm{E}-13$ & 9.27 & $9.59 \mathrm{E}-13$ & $9.59 \mathrm{E}-13$ & 8.99 & $8.23 \mathrm{E}-13$ & $7.77 \mathrm{E}-14$ \\
\hline 10.027 & 0.01 & 0.01 & 10.33 & 0.00848 & $1.19 \mathrm{E}-10$ & 9.82 & $1.85 \mathrm{E}-11$ & $4.70 \mathrm{E}-13$ & 9.5 & $1.81 \mathrm{E}-12$ & $1.81 \mathrm{E}-12$ & 9.14 & $5.53 \mathrm{E}-13$ & $7.40 \mathrm{E}-14$ \\
\hline 9.971 & 0.01 & 0.01 & 10.39 & 0.00973 & $1.19 \mathrm{E}-10$ & 10.25 & $1.64 \mathrm{E}-11$ & $4.41 \mathrm{E}-13$ & 10.16 & $3.70 \mathrm{E}-12$ & $3.70 \mathrm{E}-12$ & & & \\
\hline
\end{tabular}

* Measured aqueous phase concentration at sampling time determined via LSC. 
Table C6: $\mathrm{Pu}(\mathrm{V})$ sorption to silica under $\mathrm{CO}_{2}(\mathrm{~g})$ equilibrated conditions. Note: Reported $\mathrm{HCO}_{3}{ }^{-} / \mathrm{CO}_{3}{ }^{2-}$ concentrations based on initial solution conditions. Some diffusion of $\mathrm{CO}_{2}(\mathrm{~g})$ occurred over the course of the experiment.

\begin{tabular}{|c|c|c|c|c|c|c|c|c|c|c|c|}
\hline $\begin{array}{c}\text { Total Sample } \\
\text { Mass (g) } \\
\end{array}$ & {$[\mathrm{Na}]$} & {$\left[\mathrm{Cl}^{-}\right]$} & 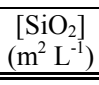 & $\begin{array}{l}{\left[\mathrm{HCO}_{3}^{-}\right]} \\
/\left[\mathrm{CO}_{3}{ }^{2-}\right] \\
\end{array}$ & {$[\mathrm{Pu}]_{\text {Total }}$} & $\begin{array}{l}\mathrm{pH} \text { after } \\
24 \text { hours } \\
\end{array}$ & $\begin{array}{c}{[\mathrm{Pu}]_{\mathrm{aqu}} * \text { after }} \\
24 \text { hours } \\
\end{array}$ & $\begin{array}{l}\text { Error }[\mathrm{Pu}]_{\text {aqu }}{ }^{*} \\
\text { after } 24 \text { hours }\end{array}$ & $\begin{array}{l}\mathrm{pH} \text { after } \\
62 \text { days } \\
\end{array}$ & $\begin{array}{c}{[\mathrm{Pu}]_{\mathrm{aqu}} * \text { after }} \\
62 \text { days } \\
\end{array}$ & $\begin{array}{l}\text { Error }[\mathrm{Pu}]_{\mathrm{aqu}}{ }^{*} \\
\text { after } 62 \text { days } \\
\end{array}$ \\
\hline 10.163 & 0.01 & 0.01 & 10.40 & $1.44 \mathrm{E}-7$ & $1.18 \mathrm{E}-10$ & 3.98 & $9.16 \mathrm{E}-11$ & $1.37 \mathrm{E}-12$ & 4.03 & $4.60 \mathrm{E}-11$ & $4.17 \mathrm{E}-13$ \\
\hline 9.992 & 0.01 & 0.01 & 10.54 & $4.38 \mathrm{E}-7$ & $1.20 \mathrm{E}-10$ & 4.63 & $8.26 \mathrm{E}-11$ & $1.27 \mathrm{E}-12$ & 4.44 & $4.11 \mathrm{E}-11$ & $3.81 \mathrm{E}-13$ \\
\hline 10.013 & 0.01 & 0.01 & 10.53 & 4.37E-7 & $1.20 \mathrm{E}-10$ & 4.46 & $8.76 \mathrm{E}-11$ & $1.32 \mathrm{E}-12$ & 4.87 & 7.64E-12 & $1.52 \mathrm{E}-13$ \\
\hline 10.143 & 0.01 & 0.01 & 10.40 & $1.33 \mathrm{E}-6$ & $1.18 \mathrm{E}-10$ & 5.12 & $6.07 \mathrm{E}-11$ & $1.00 \mathrm{E}-12$ & 5.03 & $3.47 \mathrm{E}-12$ & $1.14 \mathrm{E}-13$ \\
\hline 10.350 & 01 & 0.01 & 10.10 & 4.03E-6 & $1.15 \mathrm{E}-10$ & 5.34 & $5.93 \mathrm{E}-11$ & -13 & 5.17 & 3.65E-12 & $1.15 \mathrm{E}-13$ \\
\hline 9.972 & 0.01 & 1 & 10.57 & 4.04E-6 & $1.20 \mathrm{E}-10$ & 5.85 & $3.85 \mathrm{E}-11$ & -13 & 5. & $1.07 \mathrm{E}-12$ & E-14 \\
\hline 10.053 & 0.01 & 1 & 10.56 & $1.22 \mathrm{E}-5$ & 1.19 & 6.2 & $3.27 \mathrm{E}-11$ & 13 & 6. & 9.64 & -14 \\
\hline 10.019 & 0.01 & 0.01 & 10.51 & $3.72 \mathrm{E}-5$ & $1.20 \mathrm{E}-10$ & 6.46 & $2.30 \mathrm{E}-11$ & -13 & 6.4 & $4.35 \mathrm{E}-13$ & E-14 \\
\hline 10.008 & 0.01 & 0.01 & 10.53 & $3.72 \mathrm{E}-5$ & $1.19 \mathrm{E}-10$ & 6.72 & $2.16 \mathrm{E}-11$ & $5.14 \mathrm{E}-13$ & 6.44 & $5.60 \mathrm{E}-13$ & $8.09 \mathrm{E}-14$ \\
\hline 10.067 & 0.01 & 0.01 & 10.64 & $1.13 \mathrm{E}-4$ & $1.19 \mathrm{E}-10$ & 7.25 & $1.26 \mathrm{E}-11$ & $3.88 \mathrm{E}-13$ & 6.75 & $6.80 \mathrm{E}-13$ & $.24 \mathrm{E}-14$ \\
\hline 9.993 & 0.01 & 0.01 & 10.52 & $3.43 \mathrm{E}-4$ & $1.20 \mathrm{E}-10$ & 7.48 & $5.41 \mathrm{E}-12$ & $2.73 \mathrm{E}-13$ & 7.35 & $5.61 \mathrm{E}-13$ & $8.13 \mathrm{E}-14$ \\
\hline 10.021 & 0.01 & 0.01 & 10.52 & $3.42 \mathrm{E}-4$ & 1.19 & 7.47 & $4.88 \mathrm{E}$ & 13 & 7.45 & 5.43 & -14 \\
\hline 10 & 0.01 & & & -3 & 10 & 8.06 & 5.93 & & 7.87 & 1.0 & -14 \\
\hline & 0.01 & 0. & & 3.1 & 1.20 & 8.42 & 1.89 & & 8.3 & 1.6 & 14 \\
\hline 10.001 & 0.01 & 0. & 10 & $3.16 \mathrm{E}-3$ & 1.20 & 8.51 & $2.18 \mathrm{l}$ & 13 & 8.32 & 2.38 & -13 \\
\hline 10.017 & 0.01 & 0.0 & 10.57 & 7.20E-3 & $1.19 \mathrm{E}-10$ & 8.96 & $6.64 \mathrm{E}-11$ & $1.07 \mathrm{E}-12$ & 8.82 & $2.91 \mathrm{E}-12$ & $1.08 \mathrm{E}-13$ \\
\hline 10.030 & 0.01 & 0.01 & 10.46 & $8.46 \mathrm{E}-3$ & $1.19 \mathrm{E}-10$ & 9.38 & $8.17 \mathrm{E}-11$ & $1.25 \mathrm{E}-12$ & 9.12 & $3.68 \mathrm{E}-12$ & $1.16 \mathrm{E}-13$ \\
\hline 10.015 & 0.01 & 0.01 & 10.59 & $8.46 \mathrm{E}-3$ & $1.19 \mathrm{E}-10$ & 9.54 & $8.47 \mathrm{E}-11$ & $1.29 \mathrm{E}-12$ & 9.35 & $3.98 \mathrm{E}-12$ & $1.18 \mathrm{E}-13$ \\
\hline 10.002 & 0.01 & 0.01 & 10.50 & $9.74 \mathrm{E}-3$ & $1.19 \mathrm{E}-10$ & 10.05 & $8.23 \mathrm{E}-11$ & $1.26 \mathrm{E}-12$ & 9.86 & $6.09 \mathrm{E}-12$ & $1.38 \mathrm{E}-13$ \\
\hline
\end{tabular}

* Measured aqueous phase concentration at sampling time determined via LSC.

Table $\mathrm{C} 7: \mathrm{Pu}(\mathrm{V})$ Sorption to gibbsite under $\mathrm{CO}_{2}(\mathrm{~g})$-free conditions. Note: Data at 62 days is shown but was not used in the report or modeling efforts due to $\mathrm{CO}_{2}(\mathrm{~g})$ diffusion into the vial.

\begin{tabular}{|c|c|c|c|c|c|c|c|c|c|c|}
\hline $\begin{array}{l}\text { Total Sample } \\
\text { Mass (g) }\end{array}$ & {$\left[\mathrm{Na}^{+}\right]$} & {$\left[\mathrm{Cl}^{\prime}\right]$} & $\begin{array}{c}{\left[\alpha-\mathrm{Al}(\mathrm{OH})_{3}\right]} \\
\left(\mathrm{m}^{2} \mathrm{~L}^{-1}\right)\end{array}$ & {$[\mathrm{Pu}]_{\text {Total }}$} & $\begin{array}{l}\text { I after } \\
\text { hours }\end{array}$ & $\begin{array}{c}{[\mathrm{Pu}]_{\mathrm{aqu}}{ }^{*} \text { after }} \\
24 \text { hours }\end{array}$ & $\begin{array}{l}\text { ror }[\mathrm{Pu}]_{\mathrm{aqu}}{ }^{*} \\
\text { er } 24 \text { ours }\end{array}$ & $\begin{array}{c}\mathrm{pH} \\
\text { after } \\
62 \\
\text { days } \\
\end{array}$ & $\begin{array}{c}{[\mathrm{Pu}]_{\mathrm{aqu}}{ }^{*}} \\
\text { after } 62 \\
\text { days }\end{array}$ & $\begin{array}{c}\text { Error } \\
{[\mathrm{Pu}]_{\mathrm{aqu}}{ }^{*}} \\
\text { after 62 } \\
\text { days } \\
\end{array}$ \\
\hline & & & & & & & & 4.3 & & $\overline{1.79 \mathrm{E}-12}$ \\
\hline & & & & & & & & 4.44 & & \\
\hline 10.033 & & & & & & & & 4.48 & & 12 \\
\hline & & & & & & & & 5.01 & & \\
\hline & & & & & & & & 33 & & \\
\hline & 0.01 & 0 & & & & & & 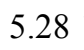 & & \\
\hline & & & & & & & & & & \\
\hline 10 & 0.01 & 0 & & & & & & 5.88 & & \\
\hline 10 & 0.01 & 0.01 & & & & & & 5.92 & & \\
\hline & 0.01 & $0 \Omega 1$ & & & & & & 6.04 & & \\
\hline & & & & & & & & $6.87^{\prime}$ & & \\
\hline & & & & & & & & 6.44 & & \\
\hline & 0. & 0 & & & & & & 6.44 & & 14 \\
\hline & 0.01 & 0 & & & & & & 6.6 & & -12 \\
\hline & & & & & & & & 6.72 & & \\
\hline & 0.01 & 0 & & & & & & 7.11 & & 7.94E-13 \\
\hline 10.121 & 0.01 & 0.01 & & & & & & 7.16 & & $8.21 \mathrm{E}-13$ \\
\hline & 0.01 & 0.01 & & & & & & 7.3 & & 7.24E-13 \\
\hline 9.131 & 0.01 & 0.01 & 0.95 & $.45 \mathrm{E}-10$ & 9.92 & $2.74 \mathrm{E}-12$ & $2.48 \mathrm{E}-13$ & 7.62 & 1.0 & $4.82 \mathrm{E}-1$ \\
\hline
\end{tabular}

* Measured aqueous phase concentration at sampling time determined via LSC. 
Table C8: $\mathrm{Pu}(\mathrm{V})$ Sorption to silica under $\mathrm{CO}_{2}(\mathrm{~g})$-free conditions. Note: Data at 62 days is shown but was not used in the report or modeling efforts due to $\mathrm{CO}_{2}(\mathrm{~g})$ diffusion into the vial.

\begin{tabular}{|c|c|c|c|c|c|c|c|c|c|c|}
\hline $\begin{array}{c}\text { Total } \\
\text { Sample } \\
\text { Mass (g) }\end{array}$ & {$\left[\mathrm{Na}^{+}\right]$} & {$\left[\mathrm{Cl}^{-}\right]$} & $\left.\begin{array}{c}{\left[\mathrm{SiO}_{2}\right]} \\
\left(\mathrm{m}^{2} \mathrm{~L}^{-}\right. \\
1\end{array}\right)$ & {$[\mathrm{Pu}]_{\text {Total }}$} & $\begin{array}{c}\mathrm{pH} \\
\text { after } \\
24 \\
\text { hours }\end{array}$ & $\begin{array}{c}{[\mathrm{Pu}]_{\text {aqu }} * \text { after }} \\
24 \text { hours }\end{array}$ & $\begin{array}{c}\text { Error } \\
{[\mathrm{Pu}]_{\text {aqu }}{ }^{*} \text { after }} \\
24 \text { hours }\end{array}$ & $\begin{array}{c}\mathrm{pH} \\
\text { after } \\
48 \\
\text { hours } \\
\end{array}$ & $\begin{array}{r}{[\mathrm{Pu}]_{\text {aqu }} * \text { aft }} \\
62 \text { days }\end{array}$ & $\begin{array}{c}\text { Error } \\
{[\mathrm{Pu}]_{\text {aqu }}{ }^{*} \text { after }} \\
62 \text { days }\end{array}$ \\
\hline 10.035 & $\overline{01}$ & 0.01 & $\overline{97}$ & $26 \mathrm{E}-10$ & 4.08 & 1 & 2 & 3.92 & 8.50 & 1. \\
\hline 9. & 0.01 & 1 & 6 & 10 & 6 & 1 & & 4.49 & & \\
\hline 10.035 & 0.0 & 0.01 & 9.97 & 0 & 5.09 & 1 & 2 & 5.04 & 5. & 1.03 \\
\hline 9.948 & 0.01 & 0.01 & 5 & 0 & 5.88 & 3. & 7.9 & 5.80 & 2.24 & 3 \\
\hline 9.931 & 0.01 & 0.01 & 77 & $1.27 \mathrm{E}$ & 6.30 & $2.60 \mathrm{E}-11$ & $6.24 \mathrm{E}-13$ & 6.20 & 1.4 & $4.16 \mathrm{E}-13$ \\
\hline 9.879 & 0.01 & 0.01 & 2 & $1.28 \mathrm{E}$ & 6.88 & $1.88 \mathrm{E}$ & $4.99 \mathrm{E}-13$ & 7.15 & 9.9 & 3.34 \\
\hline 9.916 & 0.01 & 0.01 & 10.08 & 1.27 & 7.14 & 1.0 & 3.49 & 7.39 & 4.4 & 2.16 \\
\hline 9.935 & 0. & 0.01 & 77 & & 7.95 & & 3.0 & 7.63 & & \\
\hline 10.015 & 0.01 & 0.01 & 9.99 & 1. & 7.85 & & & 7.72 & & 1.2 \\
\hline 9. & 0. & 0.01 & 10.11 & & 8.23 & & & 7.68 & & \\
\hline 10.018 & 0. & 0.01 & 9.9 & 1.26 & 8.65 & & 1.4 & 8.29 & & 1.2 \\
\hline & 0 & & 10.05 & $1.2^{\prime}$ & 9.23 & 2.3 & 1.6 & 8.79 & 2.6 & 1.6 \\
\hline 9.907 & 0.01 & 0.01 & 10.09 & $1.27 \mathrm{E}-10$ & 9.67 & $6.67 \mathrm{E}-12$ & $2.67 \mathrm{E}-13$ & 9.51 & $7.52 \mathrm{E}-12$ & $2.85 \mathrm{E}-13$ \\
\hline
\end{tabular}

* Measured aqueous phase concentration at sampling time determined via LSC. 
Table C9: $\mathrm{Pu}(\mathrm{IV})$ sorption to montmorillonite under $\mathrm{CO}_{2}(\mathrm{~g})$ equilibrated conditions. Note: Reported $\mathrm{HCO}_{3}{ }^{-} / \mathrm{CO}_{3}{ }^{2-}$ concentrations based on initial solution conditions. Some diffusion of $\mathrm{CO}_{2}(\mathrm{~g})$ occurred over the course of the experiment.

\begin{tabular}{|c|c|c|c|c|c|c|c|c|c|c|c|c|c|c|}
\hline $\begin{array}{c}\text { Total } \\
\text { Sample } \\
\text { Masss (g) }\end{array}$ & {$\left[\mathrm{Na}^{+}\right]$} & {$\left[\mathrm{Cl}^{-}\right]$} & $\begin{array}{l}{[\text { mont] }} \\
\left(\mathrm{m}^{2} \mathrm{~L}^{-1}\right)\end{array}$ & $\begin{array}{l}{\left[\mathrm{HCO}_{3}^{-}\right]} \\
/\left[\mathrm{CO}_{3}{ }^{-}{ }^{-}\right]\end{array}$ & {$[\mathrm{Pu}]_{\text {Total }}$} & $\begin{array}{l}\mathrm{pH} \text { after } \\
24 \text { hours }\end{array}$ & $\begin{array}{c}{[\mathrm{Pu}]_{\mathrm{aqu}} * \text { after } 24} \\
\text { hours }\end{array}$ & $\begin{array}{c}\text { Error }[\mathrm{Pu}]_{\mathrm{aqu}}{ }^{*} \\
\text { after } 24 \\
\text { hours }\end{array}$ & $\begin{array}{c}\mathrm{pH} \\
\text { after } 21 \\
\text { days } \\
\end{array}$ & $\begin{array}{c}{[\mathrm{Pu}]_{\mathrm{aqu}} *} \\
\text { after } 21 \\
\text { days }\end{array}$ & $\begin{array}{c}\text { Error } \\
{[\mathrm{Pu}]_{\mathrm{qqu}}{ }^{*}} \\
\text { after 21 } \\
\text { days } \\
\end{array}$ & $\begin{array}{c}\mathrm{pH} \\
\text { after } 60 \\
\text { days }\end{array}$ & $\begin{array}{c}{[\mathrm{Pu}]_{\mathrm{aqu}}{ }^{*}} \\
\text { after } 60 \\
\text { days }\end{array}$ & $\begin{array}{c}\text { Error } \\
{[\mathrm{Pu}]_{\mathrm{aqu}}{ }^{*} \text { after }} \\
60 \text { days }\end{array}$ \\
\hline 9.342 & 01 & 01 & 5.11 & בד 1.1 & 10 & 4.13 & 11 & $1 J$ & $4.2 J$ & 11 & $4.94 \mathrm{E}-13$ & 4.59 & 12 & 13 \\
\hline 9.982 & 0.01 & 0.01 & 4.79 & 4.38E-07 & $8 \mathrm{E}-10$ & 4.33 & 09E-11 & 13 & 4.43 & $2 \mathrm{E}-12$ & $3.87 \mathrm{E}-13$ & 4.52 & 12 & 2.92 \\
\hline 9.928 & 0.01 & 0.01 & 4.81 & 4.38E-07 & $1.12 \mathrm{E}-10$ & 4.19 & $1.46 \mathrm{E}-11$ & $4.80 \mathrm{E}-13$ & 4.27 & $9.27 \mathrm{E}-12$ & $3.80 \mathrm{E}-13$ & 4.42 & 4.61E-12 & $2.58 \mathrm{E}-13$ \\
\hline 9.948 & 0.01 & 0.01 & 4.80 & $1.33 \mathrm{E}-06$ & $1.07 \mathrm{E}-10$ & 5.18 & $1.04 \mathrm{E}-11$ & $4.05 \mathrm{E}-13$ & 5.45 & $8.59 \mathrm{E}-12$ & $3.71 \mathrm{E}-13$ & 5.16 & 5.53 & 2.79 \\
\hline 9.931 & 0.01 & 0.01 & 4.81 & $4.03 \mathrm{E}-06$ & $1.13 \mathrm{E}-10$ & 5.40 & 7.87E-12 & $3.52 \mathrm{E}-13$ & 5.76 & $8.06 \mathrm{E}-12$ & $3.57 \mathrm{E}-13$ & 5.83 & $5.80 \mathrm{I}$ & 2.82 \\
\hline 9.962 & 0.01 & 0.01 & 4.80 & $4.02 \mathrm{E}-06$ & $1.12 \mathrm{E}-10$ & 5.68 & $5.24 \mathrm{E}-12$ & $3.04 \mathrm{E}-13$ & 6.06 & $6.46 \mathrm{E}-12$ & $3.28 \mathrm{E}-13$ & 6.16 & $6.80 \mathrm{E}-12$ & $3.03 \mathrm{E}-13$ \\
\hline 9.981 & 0.01 & 0.01 & 4.79 & $1.22 \mathrm{E}-05$ & $1.11 \mathrm{E}-10$ & 5.81 & 7.47E-12 & $5 E-13$ & 6.08 & 7.99E-12 & $3.56 \mathrm{E}-13$ & 6.15 & $6.91 \mathrm{~F}$ & 3.061 \\
\hline 9.928 & 0.01 & 0.01 & 4.81 & $3.71 \mathrm{E}-05$ & $1.12 \mathrm{E}-10$ & 6.25 & $6.78 \mathrm{E}-12$ & 3.32E-13 & 6.53 & $6.61 \mathrm{E}-12$ & $3.31 \mathrm{E}-13$ & 6.62 & 4.30E-12 & $2.51 \mathrm{E}-13$ \\
\hline 9.949 & 0.01 & 0.01 & 4.80 & $3.71 \mathrm{E}-05$ & $1.12 \mathrm{E}-10$ & 6.70 & 7.34E-12 & $3.43 \mathrm{E}-13$ & 6.86 & $6.96 \mathrm{E}-12$ & $3.37 \mathrm{E}-13$ & 6.91 & $5.03 \mathrm{I}$ & 2.67 \\
\hline 9.921 & 0.01 & 0.01 & 4.82 & $1.13 \mathrm{E}-04$ & $1.13 \mathrm{E}-10$ & 6.78 & $8.24 \mathrm{E}-12$ & $3.59 \mathrm{E}-13$ & 6.96 & $7.81 \mathrm{E}-12$ & $3.52 \mathrm{E}-13$ & 6.94 & $5.45 \mathrm{E}-12$ & $2.75 \mathrm{E}-13$ \\
\hline 9.944 & 0.01 & 0.01 & 4.80 & $3.42 \mathrm{E}-04$ & $1.11 \mathrm{E}-10$ & 7.31 & $1.10 \mathrm{E}-11$ & $4.14 \mathrm{E}-13$ & 7.40 & $1.14 \mathrm{E}-11$ & $4.22 \mathrm{E}-13$ & 7.41 & 7.79E-12 & $3.24 \mathrm{E}-13$ \\
\hline 9.920 & 0.01 & 0.01 & 4.82 & $3.43 \mathrm{E}-04$ & $1.10 \mathrm{E}-10$ & 7.54 & $1.34 \mathrm{E}-11$ & $4.59 \mathrm{E}-13$ & 7.41 & $1.25 \mathrm{E}-11$ & $4.44 \mathrm{E}-13$ & 7.42 & 4.99E-12 & $2.66 \mathrm{E}-13$ \\
\hline 9.912 & 0.01 & 0.01 & 4.82 & $1.04 \mathrm{E}-03$ & $1.13 \mathrm{E}-10$ & 7.92 & $1.44 \mathrm{E}-11$ & 4.74E-13 & 7.89 & $2.11 \mathrm{E}-11$ & $6.02 \mathrm{E}-13$ & 7.89 & $1.08 \mathrm{E}-11$ & $3.85 \mathrm{E}-13$ \\
\hline 9.904 & 0.01 & 0.01 & 4.82 & $2.16 \mathrm{E}-03$ & $1.12 \mathrm{E}-10$ & 8.56 & $1.12 \mathrm{E}-11$ & $4.15 \mathrm{E}-13$ & 8.44 & $1.24 \mathrm{E}-11$ & $4.40 \mathrm{E}-13$ & 8.33 & $1.09 \mathrm{E}-11$ & $3.89 \mathrm{E}-13$ \\
\hline 9.923 & 0.01 & 0.01 & 4.81 & $3.16 \mathrm{E}-03$ & $1.11 \mathrm{E}-10$ & 8.71 & $9.98 \mathrm{E}-12$ & $3.93 \mathrm{E}-13$ & 8.51 & $1.20 \mathrm{E}-11$ & 4.33E-13 & 8.45 & $1.06 \mathrm{E}-11$ & $3.82 \mathrm{E}-13$ \\
\hline 9.955 & 0.01 & 0.01 & 4.80 & 7.20E-03 & $1.10 \mathrm{E}-10$ & 9.02 & $1.91 \mathrm{E}-11$ & $5.68 \mathrm{E}-13$ & 8.99 & $1.94 \mathrm{E}-11$ & $5.75 \mathrm{E}-13$ & 8.94 & $1.63 \mathrm{E}-11$ & $4.98 \mathrm{E}-13$ \\
\hline 9.912 & 0.01 & 0.01 & 4.82 & 8.01E-03 & $1.11 \mathrm{E}-10$ & 9.27 & $2.30 \mathrm{E}-11$ & $6.42 \mathrm{E}-13$ & 9.20 & $2.37 \mathrm{E}-11$ & $6.56 \mathrm{E}-13$ & 9.12 & $2.28 \mathrm{E}-11$ & $6.24 \mathrm{E}-13$ \\
\hline 9.905 & 0.01 & 0.01 & 4.82 & $8.46 \mathrm{E}-03$ & $1.12 \mathrm{E}-10$ & 9.49 & $2.62 \mathrm{E}-11$ & 7.01E-13 & 9.44 & $2.24 \mathrm{E}-11$ & $6.29 \mathrm{E}-13$ & 9.37 & $1.89 \mathrm{E}-11$ & $5.45 \mathrm{E}-13$ \\
\hline 9.930 & 0.01 & 0.01 & 4.81 & $9.69 \mathrm{E}-03$ & $1.12 \mathrm{E}-10$ & 10.12 & $3.48 \mathrm{E}-11$ & $8.68 \mathrm{E}-13$ & 10.22 & $3.36 \mathrm{E}-11$ & $8.47 \mathrm{E}-13$ & 10.15 & $2.91 \mathrm{E}-11$ & $7.48 \mathrm{E}-13$ \\
\hline
\end{tabular}

* Measured aqueous phase concentration at sampling time determined via LSC. 
Table $\mathrm{C} 10: \mathrm{Pu}(\mathrm{V})$ sorption to montmorillonite under $\mathrm{CO}_{2}(\mathrm{~g})$ equilibrated conditions. Note: Reported $\mathrm{HCO}_{3}{ }^{-} / \mathrm{CO}_{3}{ }^{2-}$ concentrations based on initial solution conditions. Some diffusion of $\mathrm{CO}_{2}(\mathrm{~g})$ occurred over the course of the experiment.

\begin{tabular}{|c|c|c|c|c|c|c|c|c|c|c|c|c|c|c|c|c|c|}
\hline $\begin{array}{c}\text { Total Sample } \\
\text { Mass (g) }\end{array}$ & {$\left[\mathrm{Na}^{+}\right]$} & {$\left[\mathrm{Cl}^{-}\right]$} & $\begin{array}{l}{[\text { mont }]} \\
\left(\mathrm{m}^{2} \mathrm{~L}^{-1}\right)\end{array}$ & $\begin{array}{l}{\left[\mathrm{HCO}_{3}^{-}\right]} \\
/\left[\mathrm{CO}_{3}{ }^{2-}\right]\end{array}$ & {$[\mathrm{Pu}]_{\text {Total }}$} & $\begin{array}{l}\mathrm{pH} \text { after } \\
24 \text { hours }\end{array}$ & $\begin{array}{c}{[\mathrm{Pu}]_{\mathrm{aqu}} * \text { after }} \\
24 \text { hours }\end{array}$ & $\begin{array}{c}\text { Error } \\
{[\mathrm{Pu}]_{\mathrm{aqu}} *} \\
\text { after } 24 \\
\text { hours }\end{array}$ & $\begin{array}{c}\mathrm{pH} \\
\text { after } 21 \\
\text { days }\end{array}$ & $\begin{array}{c}{[\mathrm{Pu}]_{\mathrm{aqu}}{ }^{*}} \\
\text { after } 21 \\
\text { days }\end{array}$ & $\begin{array}{c}\text { Error } \\
{[\mathrm{Pu}]_{\mathrm{aqu}} *} \\
\text { after } 21 \\
\text { days }\end{array}$ & $\begin{array}{c}\mathrm{pH} \\
\text { after } 60 \\
\text { days }\end{array}$ & $\begin{array}{c}{[\mathrm{Pu}]_{\mathrm{aqu}}{ }^{*}} \\
\text { after } 60 \\
\text { days }\end{array}$ & $\begin{array}{c}\text { Error } \\
{[\mathrm{Pu}]_{\text {aqu }} *} \\
\text { after } 60 \\
\text { days }\end{array}$ & $\begin{array}{l}\text { pH after } \\
90 \text { days }\end{array}$ & $\begin{array}{c}{[\mathrm{Pu}]_{\mathrm{aqu}} *} \\
\text { after } 90 \\
\text { days }\end{array}$ & $\begin{array}{c}\text { Error } \\
{[\mathrm{Pu}]_{\text {aqu }} *} \\
\text { after } 90 \\
\text { days }\end{array}$ \\
\hline 10.023 & 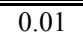 & 0.01 & 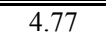 & $=1.44 \mathrm{E}-07$ & $1.49 \mathrm{E}-10$ & 4.05 & $1.23 \mathrm{E}-10$ & $81.15 \mathrm{E}-12$ & 4.09 & $8.67 \mathrm{E}-11$ & $8.05 \mathrm{E}-13$ & 4.26 & $2.30 \mathrm{E}-12$ & $\begin{array}{l}2.48 \mathrm{E}-13 \\
\end{array}$ & 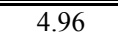 & $1.90 \mathrm{E}-12$ & $2.02 \mathrm{E}-13$ \\
\hline 10.032 & 0.01 & 0.01 & 4.76 & $4.38 \mathrm{E}-07$ & $1.49 \mathrm{E}-10$ & 4.50 & 1.39E-10 & $1.25 \mathrm{E}-12$ & 4.47 & $9.32 \mathrm{E}-11$ & $9.73 \mathrm{E}-13$ & 4.73 & $3.42 \mathrm{E}-11$ & $5.72 \mathrm{E}-13$ & 5.28 & $8.56 \mathrm{E}-12$ & $2.59 \mathrm{E}-13$ \\
\hline 10.021 & 0.01 & 0.01 & 4.77 & $4.38 \mathrm{E}-07$ & $1.49 \mathrm{E}-10$ & 4.45 & $1.41 \mathrm{E}-10$ & $1.26 \mathrm{E}-12$ & 4.52 & $1.01 \mathrm{E}-10$ & $1.02 \mathrm{E}-12$ & & & & & & \\
\hline 10.021 & 0.01 & 0.01 & 4.77 & $1.33 \mathrm{E}-06$ & $1.50 \mathrm{E}-10$ & 4.90 & $1.42 \mathrm{E}-10$ & $1.26 \mathrm{E}-12$ & 5.08 & $1.04 \mathrm{E}-10$ & $1.04 \mathrm{E}-12$ & 5.50 & $5.02 \mathrm{E}-11$ & $6.92 \mathrm{E}-13$ & 5.94 & $3.30 \mathrm{E}-11$ & $4.28 \mathrm{E}-13$ \\
\hline 10.051 & 0.01 & 0.01 & 4.75 & 4.03E-06 & $1.49 \mathrm{E}-10$ & 5.58 & $1.42 \mathrm{E}-10$ & $1.27 \mathrm{E}-12$ & 5.82 & $1.03 \mathrm{E}-10$ & $1.03 \mathrm{E}-12$ & 5.98 & $5.81 \mathrm{E}-11$ & 7.49E-13 & 6.03 & 4.67E-11 & $5.11 \mathrm{E}-13$ \\
\hline 10.017 & 0.01 & 0.01 & 4.77 & 4.03E-06 & $1.51 \mathrm{E}-10$ & 5.68 & $1.43 \mathrm{E}-10$ & $1.26 \mathrm{E}-12$ & 6.10 & $1.03 \mathrm{E}-10$ & $1.03 \mathrm{E}-12$ & 6.22 & $6.72 \mathrm{E}-11$ & $8.08 \mathrm{E}-13$ & 6.35 & $4.09 \mathrm{E}-11$ & $4.78 \mathrm{E}-13$ \\
\hline 10.075 & 0.01 & 0.01 & 4.74 & $1.22 \mathrm{E}-05$ & $1.49 \mathrm{E}-10$ & 5.74 & $1.43 \mathrm{E}-10$ & $1.26 \mathrm{E}-12$ & 6.29 & $9.58 \mathrm{E}-11$ & $9.88 \mathrm{E}-13$ & 6.33 & $4.67 \mathrm{E}-11$ & $6.67 \mathrm{E}-13$ & 6.68 & $2.57 \mathrm{E}-11$ & $3.80 \mathrm{E}-13$ \\
\hline 9.987 & 0.01 & 0.01 & 4.78 & $3.72 \mathrm{E}-05$ & $1.50 \mathrm{E}-10$ & 6.74 & $1.41 \mathrm{E}-10$ & $1.25 \mathrm{E}-12$ & 6.66 & $9.16 \mathrm{E}-11$ & $9.63 \mathrm{E}-13$ & 6.65 & $4.20 \mathrm{E}-11$ & $6.32 \mathrm{E}-13$ & 6.68 & $2.99 \mathrm{E}-11$ & $4.09 \mathrm{E}-13$ \\
\hline 10.003 & 0.01 & 0.01 & 4.78 & $3.72 \mathrm{E}-05$ & $1.49 \mathrm{E}-10$ & 6.86 & $1.42 \mathrm{E}-10$ & $1.26 \mathrm{E}-12$ & 6.72 & $9.36 \mathrm{E}-11$ & $9.77 \mathrm{E}-13$ & 6.71 & $4.63 \mathrm{E}-11$ & $6.65 \mathrm{E}-13$ & 7.01 & $2.01 \mathrm{E}-11$ & $3.44 \mathrm{E}-13$ \\
\hline 10.026 & 0.01 & 0.01 & 4.76 & $1.13 \mathrm{E}-04$ & $1.50 \mathrm{E}-10$ & 7.14 & $1.38 \mathrm{E}-10$ & $1.24 \mathrm{E}-12$ & 6.98 & $7.59 \mathrm{E}-11$ & $8.63 \mathrm{E}-13$ & 6.98 & $3.03 \mathrm{E}-11$ & $5.41 \mathrm{E}-13$ & 7.45 & $2.91 \mathrm{E}-11$ & $4.03 \mathrm{E}-13$ \\
\hline 10.032 & 0.01 & 0.01 & 4.76 & $3.43 \mathrm{E}-04$ & $1.50 \mathrm{E}-10$ & 7.68 & $1.34 \mathrm{E}-10$ & $1.22 \mathrm{E}-12$ & 7.41 & $7.80 \mathrm{E}-11$ & $8.76 \mathrm{E}-13$ & 7.45 & $3.94 \mathrm{E}-11$ & $6.13 \mathrm{E}-13$ & 7.48 & $2.61 \mathrm{E}-11$ & $3.82 \mathrm{E}-13$ \\
\hline 10.006 & 0.01 & 0.01 & 4.77 & $3.43 \mathrm{E}-04$ & $1.50 \mathrm{E}-10$ & 7.56 & $1.36 \mathrm{E}-10$ & $1.23 \mathrm{E}-12$ & 7.41 & 7.46E-11 & $8.54 \mathrm{E}-13$ & 7.45 & $3.58 \mathrm{E}-11$ & $5.85 \mathrm{E}-13$ & 7.98 & $1.74 \mathrm{E}-11$ & $3.26 \mathrm{E}-13$ \\
\hline 10.016 & 0.01 & 0.01 & 4.77 & $1.04 \mathrm{E}-03$ & $1.50 \mathrm{E}-10$ & 7.21 & $1.35 \mathrm{E}-10$ & $1.22 \mathrm{E}-12$ & 7.87 & $3.78 \mathrm{E}-11$ & $5.98 \mathrm{E}-13$ & 7.86 & $1.89 \mathrm{E}-11$ & $4.41 \mathrm{E}-13$ & & & \\
\hline 9.770 & 0.01 & 0.01 & 4.89 & $3.16 \mathrm{E}-03$ & $1.53 \mathrm{E}-10$ & 8.04 & $1.17 \mathrm{E}-10$ & $1.11 \mathrm{E}-12$ & 8.08 & $7.78 \mathrm{E}-11$ & $8.76 \mathrm{E}-13$ & 8.18 & $3.38 \mathrm{E}-11$ & $5.68 \mathrm{E}-13$ & 7.22 & $2.47 \mathrm{E}-11$ & $3.7 \mathrm{E}-13$ \\
\hline 10.001 & 0.01 & 0.01 & 4.78 & $7.20 \mathrm{E}-03$ & $1.49 \mathrm{E}-10$ & 8.85 & $5.60 \mathrm{E}-11$ & $7.31 \mathrm{E}-13$ & 8.83 & $2.26 \mathrm{E}-11$ & $4.73 \mathrm{E}-13$ & 8.82 & $1.73 \mathrm{E}-11$ & $4.33 \mathrm{E}-13$ & 8.89 & $1.42 \mathrm{E}-11$ & $3.01 \mathrm{E}-13$ \\
\hline 10.006 & 0.01 & 0.01 & 4.77 & $8.45 \mathrm{E}-03$ & $1.50 \mathrm{E}-10$ & 9.48 & $5.39 \mathrm{E}-11$ & $7.16 \mathrm{E}-13$ & 9.41 & $1.71 \mathrm{E}-11$ & $4.22 \mathrm{E}-13$ & 9.30 & $9.86 \mathrm{E}-12$ & $3.45 \mathrm{E}-13$ & 9.24 & $9.48 \mathrm{E}-12$ & $2.72 \mathrm{E}-13$ \\
\hline 10.033 & 0.01 & 0.01 & 4.76 & $8.45 \mathrm{E}-03$ & $1.49 \mathrm{E}-10$ & 9.58 & $5.33 \mathrm{E}-11$ & $7.11 \mathrm{E}-13$ & 9.52 & $2.09 \mathrm{E}-11$ & $4.58 \mathrm{E}-13$ & 9.44 & $1.42 \mathrm{E}-11$ & $3.96 \mathrm{E}-13$ & 9.40 & $1.19 \mathrm{E}-11$ & $2.84 \mathrm{E}-13$ \\
\hline 9.996 & 0.01 & 0.01 & 4.78 & $9.72 \mathrm{E}-03$ & $1.50 \mathrm{E}-10$ & 10.12 & $5.11 \mathrm{E}-11$ & $6.96 \mathrm{E}-13$ & 10.06 & 4.19E-11 & $6.31 \mathrm{E}-13$ & 10.01 & $2.61 \mathrm{E}-11$ & $5.03 \mathrm{E}-13$ & 9.98 & $2.10 \mathrm{E}-11$ & $3.52 \mathrm{E}-13$ \\
\hline
\end{tabular}

* Measured aqueous phase concentration at sampling time determined via LSC. 
Table C11: $\mathrm{Pu}(\mathrm{IV})$ Sorption to montmorillonite under $\mathrm{CO}_{2}(\mathrm{~g})$-free conditions. Note: Data at 62 days is shown but was not used in the report or modeling efforts due to $\mathrm{CO}_{2}(\mathrm{~g})$ diffusion into the vial.

\begin{tabular}{|c|c|c|c|c|c|c|c|c|c|c|}
\hline $\begin{array}{c}\text { Total } \\
\text { Sample } \\
\text { Mass (g) }\end{array}$ & $\left.\mathrm{Na}^{+}\right]$ & {$\left[\mathrm{Cl}^{-}\right]$} & $\begin{array}{l}{[\text { Mont] }} \\
\left(\mathrm{m}^{2} \mathrm{~L}^{-1}\right)\end{array}$ & |Total & $\begin{array}{c}\mathrm{pH} \\
\text { after } 24 \\
\text { hours }\end{array}$ & $\begin{array}{c}{[\mathrm{Pu}]_{\text {aqu }} * \text { after }} \\
24 \text { hours }\end{array}$ & $\begin{array}{c}\text { Error } \\
{[\text { Pu }]_{\text {aqu }}{ }^{*}} \\
\text { after } 24 \\
\text { hours } \\
\end{array}$ & er & 02 & $\begin{array}{c}\text { Error } \\
{[\mathrm{Pu}]_{\mathrm{aqu}}^{*} \text { after }} \\
62 \text { days }\end{array}$ \\
\hline 10.071 & 51 & & & & & & $83 \mathrm{E}-13$ & & & \\
\hline 9.98 & & & & & & & & & & \\
\hline & & & & & & & & & & \\
\hline & & & & & & & & & & \\
\hline & & & & & & & & & & \\
\hline & & & & & & & & & & \\
\hline & 0 & 0 & & & 6. & & 3 & & & \\
\hline & & & & & & & & & & \\
\hline & & & & & & & & & & \\
\hline & & & & & & & & & & \\
\hline & & & & & & & & & & \\
\hline & & & & & & & & & & \\
\hline & & & & & & & & & & \\
\hline & & & & & & & & & & \\
\hline & & & & & & & 13 & & & \\
\hline & & & & & & & & & & \\
\hline 9. & 0. & & & & & & 6.86 & 7.13 & & -13 \\
\hline & 0. & 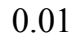 & & & & & $8.70 \mathrm{E}-13$ & 7.27 & & -13 \\
\hline 9.964 & .01 & .01 & 4.79 & $.23 \mathrm{E}-10$ & 10.05 & $6.52 \mathrm{E}-11$ & $8.65 \mathrm{E}-13$ & 7.52 & $5.95 \mathrm{E}-11$ & $8.20 \mathrm{E}-13$ \\
\hline
\end{tabular}

* Measured aqueous phase concentration at sampling time determined via LSC.

Table $\mathrm{C} 12$ : $\mathrm{Pu}(\mathrm{V})$ Sorption to montmorillonite under $\mathrm{CO}_{2}(\mathrm{~g})$-free conditions. Note: Data at 62 days is shown but was not used in the report or modeling efforts due to $\mathrm{CO}_{2}(\mathrm{~g})$ diffusion into the vial.

\begin{tabular}{|c|c|c|c|c|c|c|c|c|c|c|}
\hline $\begin{array}{l}\text { Total Sample } \\
\text { Mass (g) }\end{array}$ & {$\left[\mathrm{a}^{*}\right]$} & $\left.\mathrm{Cl}^{\prime}\right]$ & $\begin{array}{l}{[\text { Mont }]} \\
\left(\mathrm{m}^{2} \mathrm{~L}^{-1}\right)\end{array}$ & u $]_{\text {Total }}$ & $\begin{array}{l}\text { ter } \\
\text { urs }\end{array}$ & $\begin{array}{r}{[\mathrm{Pu}]_{\mathrm{aqu}}{ }^{*}} \\
24 \text { hou }\end{array}$ & $\begin{array}{l}u^{*} \\
\text { irs }\end{array}$ & $\begin{array}{c}\mathrm{pH} \\
\text { after } \\
62 \\
\text { days } \\
\end{array}$ & $\begin{array}{c}{[\mathrm{Pu}]_{\mathrm{aqu}}{ }^{*}} \\
\text { after } 62 \\
\text { days }\end{array}$ & $\begin{array}{c}\text { Error } \\
{[\mathrm{Pu}]_{\mathrm{aqu}} *} \\
\text { after } 62 \\
\text { days }\end{array}$ \\
\hline & & & & & & & & 4.33 & & $61 \mathrm{E}-$ \\
\hline 9.9 & & & & & & & & 4.67 & & $18 \mathrm{E}-12$ \\
\hline 9.9 & & & & & & & & 4.70 & & $.02 \mathrm{E}^{-1}$ \\
\hline 9.9 & & & & & & & & 5.2 & & 15 \\
\hline 9.9 & & 0. & & & 5.9 & & & 5.73 & & $1.0 / \mathrm{E}-12$ \\
\hline & & 0. & & & & & & 5.91 & & -13 \\
\hline & & & & & & & & 5.91 & & \\
\hline & & & & & & & & - & & \\
\hline & & & & & & & & 6.17 & & -13 \\
\hline & & & & & & & & $6.0^{\circ}$ & & -13 \\
\hline & & & & & & & & 6.41 & & E-13 \\
\hline & & 0. & & & 6.9 & & & 6.29 & & $7.16 \mathrm{E}-13$ \\
\hline & & & & & & & & 6.41 & & $6.56 \mathrm{E}-13$ \\
\hline & & & & & & & & 6.58 & & $6.27 \mathrm{E}-13$ \\
\hline 10 & & 0 & & & 8.0 & & & 6.44 & & $5.24 \mathrm{E}-13$ \\
\hline & 01 & 0.01 & & & 8.5 & & & 6.66 & & $7.78 \mathrm{E}-13$ \\
\hline & 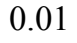 & & & & & & & 6.7 & & $97 \mathrm{E}-13$ \\
\hline 9.678 & 0.01 & 0.01 & 4.94 & $1.35 \mathrm{E}-10$ & 9.44 & $9.73 \mathrm{E}-12$ & $3.35 \mathrm{E}-13$ & 6.93 & 0.51511 & $1.03 \mathrm{E}-12$ \\
\hline
\end{tabular}

* Measured aqueous phase concentration at sampling time determined via LSC. 